РИСОВОАСТВО

НАУЧНО-ПРОИЗВОАСТВЕННЫЙ ЖУРНАА

\section{ISSN 1684-2464}

Учрелитель: Фелеральное госуаарственное бюАжетное научное учрежАение «Федеральный научный центр риса»

Изаяется с 2002 года

ПериоАичность - 4 выпуска в гоА

Журнал вк^ючен в Перечень ведущих рецензируемых научных журналов и изАаний, в КОторых АОлжны быть опубликованы основные научные результаты Аиссертаций на соискание ученой степени Аоктора наук, на соискание Ученой степени канАИАата наук. Аата вкАючения ИзАания в перечень - 6 июня 2017 гола.

ГАавныЙ реАवКтор

C. В. ГАРКУША (ФНЦ риса),

A-р c.--х. наук, профессор

Заместитель главного реАактора

B. С. КОВА^ЕВ (ФНЦ риса),

A-р c.-Х. наук, профессор

Научный редактор

Н. Г. ТУМАНЬЯН (ФНЦ риса)

А-р биол. наук, профессор

РеАакционная комлегия

И. Б. АБЛОВА (НЦЗ им. П. П. Аукьяненко), А-р с.-х. наук Т. Ф. БОЧКО (КУбГУ), КанА. биОА. наук

АЖАО НЬЯНАИ (Китай, АяОНИнСКая АкаАемия с.-Х. Наук), Ph.D

В. А. АЗЮБА (ФНЦ риса), А-р биол. наук, профессор

^. В. ЕСАУ^ОВА (ФНЦ риса), КанА. биол. наук

Г. А. ЗЕАЕНСКИЙ (ФНЦ рИса), А-р с.-Х. Наук, профессор

С. В. КИЗИНЕК (РПЗ «КрасноармейСКИй»

им. А. И. Майстренко), А-р с.-Х. наук

C. B. KOPOЛЕBA (ФНЦ рИСа), КанА. С.-Х. HaYK

П. И. КОСТЫАЕВ (ФНЦ риса), А-р с.-Х. Наук, профессор

В. А. МАААТКО (ФНЦ риса), канА. с.-Х. Наук

Ж. М. МУХИНА (ФНЦ риса), А-р биол. Нaук

А. Н. ПОАОАЬСКИХ (КазахСКИЙ НИИ РИСОвОАСТва

им. И. Жахаева), А-р с.-Х. наук

М. А. СКАЖЕННИК (ФНЦ рИСа), А-р бИОЛ. НауК

А.И. СУПРУНОВ (НЦЗ им. П. П. АУКЬяненКО), А-Р С.-Х. наук

Е. М. ХАРИТОНОВ (ФНЦ риса), वкаАемик РАН, профессор

М. И. ЧЕБОТАРЕВ (КУбГАУ), А-Р ТЕХН. НवУК, ПрофесСОр

A. Х. ШЕУАЖЕН (ФНЦ рИСа), वКаАеМИК РАН, прОфессор Венцзин ЧЖЭН (ЛЯонинский научно-ИсслеАОвательСКИй институт риса, Китай), проф.

Массимо БИ^ОНИ (Итальянская экспериментальная рисовая станция), А-р с.-Х. наук

Е.В. АУБИНА (ФНЦ риса), А-р биол. наук

ПеревоАчик: И.С. ПАНКОВА (ФНЦ риса)

Корректор: С.С. ЧИЖИКОВА (ФНЦ риса)

Алрес реАवкции:

350921, Россия, Краснодар, Белозерный, 3.

arri_kub@mail.ru, «B реАакцию журнала»

Научный редактор: тел.: (861) 229-42-66

СвиАетельство о регистрации СМИ

№ 019255 от 29.09.1999, выАано ГосуАарственным комитетом РФ по печати.

В журнале публикуются оригинальные статьи проблемного и научно-практического характера, представляющие собой результаты исслеАОваний по физиологии, биотехнологии, биохимии, агрохимии; метоАические рекоменАации по использованию сортов в различных почвенно-климатических регионах; сообщения о селекционных и семеноводческих Аостижениях; рассмотрение производственных и экономических проблем отрасли; а также обзорные, систематизирующие, переводные статьи, рецензии.

\section{RICE GROWING}

SCIENTIFIC RESEARCH AND PRODUCTION MAGAZINE

Founder: Federal State Budgetary Scientific Institution «Federal Scientific Rice Centre»

Published since 2002

Periodicity 4 issues a year

Journal is included into List of Leading peer-reviewed journals and publications, where basic scientific results of doctoral dissertations and Ph.D. dissertations should be published. Date of issue inclusion into the list - Juny 6th 2017.

Editor-in-Chief

S. V. GARKUSHA (FSC of rice),

Dr. of agricultural sciences

Deputy Chief Editor

V. S. KOVALYOV (FSC of rice),

Doctor of Agricultural Sciences, professor,

Scientific Editor

N.G. TUMANYAN (FSC of rice),

Doctor of Biological Sciences, professor

Editorial Board

I. B. ABLOVA (Krasnodar Research Institute of Agriculture named after P. P. Lukianenko), Ph.D. in biological sciences

T. F. BOCHKO (KubSU), Ph.D. in biological sciences

ZHAO NIANLI (China, Liaonong Academy of Agricultural Science), Ph. D

V. A. DZYUBA (FSC of rice), Dr. of biological sciences, professor

L. V. ESAULOVA (FSC of rice), Ph.D. in biological sciences

G. L. ZELENSKY (FSC of rice), Dr. of agricultural sciences, professor

S. V. KIZINEK (Krasnoarmeysky Rice Growing Pedigree Plant named after A. I. Maystrenko), Dr. of agricultural sciences

S. V. KOROLYOVA (FSC of rice), Ph. D. in agricultural sciences P. I. KOSTYLEV (SSE «ARC «Donskoy»), Dr. of agricultural sciences, professor

V. A. LADATKO (FSC of rice), Ph.D. in agricultural sciences Zh. M. MUKHINA (FSC of rice), Dr. of biological sciences A. N. PODOLSKIKH (Kazakh Scientific Research Institute of Rice Growing named after l. Zhakhaev), Dr. of agricultural sciences M. A. SKAZHENNIK (FSC of rice), Dr. of biological sciences A. I. SUPRUNOV (Krasnodar Research Institute of Agriculture named after P. P. Lukianenko), Dr. of agricultural sciences E. M. KHARITONOV (Academician of Russian Academy of Sciences), professor

M. I. CHEBOTAREV (KubSAU). Dr. of engeneering sciences, professor A. KH. SHEUDZHEN (FSC of rice), Academician of Russian

Academy of Sciences, professor

Wenjing ZHENG (Liaoning Rice Research Institute of China), prof. Massimo BILONI (Italian Rice Experiment Station), Dr. of agriculture

E.V. DUBINA (FSC of rice), Dr. of biology

Interpreter I. S. PANKOVA (FSC of rice)

Proofreader: S.S. CHIZHIKOVA (FSC of rice)

Address:

3 Belozerny, Krasnodar, 350921, Russia

FSC of rice_kub@mail.ru, "Attn. Editors of the Magazine"

Scientific Editor: tel. (861) 229-42-66

Mass Media Registration Certificate

№ 019255 dd. 29.09.1999, issued by National Press Committee of the Russian Federation.

The magazine features original articles addressing problem areas and applied scientific research results (namely, those related to physiology, biotechnology, biochemistry and agrochemistry); methodological recommendations on the use of rice varieties in various soil and climatic regions; reports on breeding and seed growing achievements; reviews of production and financial issues faced by the industry; overviews, systematizations, translations and reviews of articles. 


\section{COАЕРЖАНИЕ}

\section{НАУЧНЫЕ ПУБАИКАЦИИ}

\section{А.Г. Зеленский, Е.Ю. Гненный, Г.^.Зеленский}

Изменчивость количественных признаков среАнеспелых сортов риса

в условиях конкурского испытания

А.М. Оглы, В.С. Ковалев, Е.П. Максименко

Проявление краевого эффекта в мелкоделяночных опытах и способы

его учета

\section{Е.Ю. Гненный, М.А. Ткаченко, Г.А. Зеленский}

Реакция сортов риса на различную обеспеченность влагой в периоА

прорастания

\section{Н.В. Остапенко, Р.Р. Ажамирзе, Н.Н. Чинченко}

Новы сорт риса Аиалог

\section{С.В. Гаркуша, С.А. Тешева, А.А. Пищенко}

Эффективность беспрополочной технологии выращивания элитных семян

риса в Краснодарском крае

\section{А.С. Перевязка, Н.И. Перевязка, А.И. Супрунов}

СозАание ранееспелых и среАнеранних гибриАов кукурузы с участием новых

\section{А.С. Перевязка, Н.И. Перевязка, А.И. Супрунов}

Изучение общей комбинационной способности новых раннеспелых и среАнеранних автоАип^ОИАНЫх Аиний кукурузы в условиях центральной зоны Краснодарского края

\section{К.Р. Бикметова, Ю.С. Смирнова}

ИсслеАование эффективности различных способов стерилизации эксп^антов скумпии кожевенной (cotinus coggygria) в ус^овиях микрок^она^ьного 


\section{С.В. Королева, С.А. Аякунчак, Н.В.Полякова, О.Г. Пистун}

Оценка инбреАных линий и гибриАных комбинаций белокочанной капусты на устойчивость к сосуАистому бактериозу (Xanthomonas campestris pv. campestris)

\section{И. В. Козлова}

Изучение комбинационной способности ^иний томата по признакам

проАУКтИвности и ее состая^яюЩим

\section{А.Б. Никитенко, В.П. Малаканова, М.В. Марченко, С.А. Кирячек}

Влияние органоминеральных уАобрений на урожайность роАительских форм

гибрида кукурузы КрасноАарский 291 АМВ

\section{В.Э. ^азько, О.В. Якимова, Е.Н. Благородова}

Агрономическая эффективность препарата зеромикс 3000 PРМ

на семеноводческих посевах Аыни сорта Славия

\section{О. В. Зеленская}

Экологический риск распространения на рисовых полях сорных растений,

устойчивых к гербициАам

\section{С.В. Гаркуша, С.А. Тешева}

Оценка экономический эффективности выращивания кукурузы в краснодар-

ском крае

\section{ЮБИАЕИ}

\section{М. А. Скаженник, Е.Е. Иваненко}

Первый камень в фунааменте Кубанской школы физиологии растений

(к 140-летию со Аня рожАения акаАемика Николая АлексанАровича Максимова) 


\section{TABLE OF CONTENTS}

\section{SCIENTIFIC PUBLICATIONS}

\section{A. G. Zelensky, E. Y. Gnennyy, G. L. Zelensky}

Variability of quantitative traits of medium-ripening rice varieties under competitive testing conditions

\section{A. M. Ogly, V. S. Kovalev, E. P. Maksimenko}

Manifest of the edge effect in small-plot experiments and metods of taking it intro account

\section{E. Y. Gnennyy, G. L. Zelensky, M. A. Tkachenko}

Реакция сортов риса на различную обеспеченность влагой в периоА

прорастания

\section{N. V. Ostapenko, R. R. Dzhamirze, N. N. Chinchenko}

New rice variety Dialog

\section{S. V. Garkusha, S. A. Tesheva, D. A. Pischenko}

Efficiency of weeding-free technology for growing elite rice seeds

in Krasnodar region

\section{S. Perevyazka, N. I. Perevyazka, A. I. Suprunov}

Creation of early maturing and mid-early maize hybrids with the participation of

\section{S. Perevyazka, N. I. Perevyazka, A. I. Suprunov}

Study of the general combining ability of new early maturing and mid-early

autodiploid lines of maize in the central zone of krasnodar territory

\section{K. R. Bikmetova, Y. S. Smirnova}

Study of efficiency of different methods of sterilization of explants of leather scumpy 


\section{TABLE OF CONTENTS}

\section{S. V. Koroleva, S. A. Dyakunchak, N. V. Polyakova, O. G. Pistun}

\section{V. Kozlova}

Study of tomato lines combining abilty by productivity

\section{A. B. Nikitenko, V. P. Malakanova, M. V. Marchenko, S. A. Kiryachek}

\section{E. Lazko, O. V. Yakimova, E. N. Blagorodova}

Agronomic efficiency of the preparation zeromix 3000 ppm on seed crops of melon variety Slavia

\section{O. V. Zelenskaya}

Ecological risk of herbicide-resistant weeds distribution in rice fields. overview

\section{S. V. Garkusha, S. A. Tesheva}

Evaluation of efficiency of corn growing in krasnodar region

\section{THE NAME IN SCIENCE}

\section{A. Skazhennik, E. E. Ivanenko}

the first stone of the kuban school of plant physiology (to the 140th anniversary of 


\section{ИЗМЕНЧИВОСТЬ КОЛИЧЕСТВЕННЫХ ПРИЗНАКОВ СРЕДНЕСПЕЛЫХ СОРТОВ РИСА В УСЛОВИЯХ КОНКУРСНОГО ИСПЫТАНИЯ}

Исходный материал в селекции новых сортов риса проходит многолетнюю оценку по комплексу хозяйственно-ценных признаков. Заключительным этапом изучения созданных образцов является конкурсное испытание. Здесь полевые опыты по уровню питания, норме высева, срокам и способам посева приближены к производственным. Кроме полевых оценок, растения и получаемое зерно продолжают изучать, используя лабораторные методы. Среди них важное значение имеют биометрический анализ растений и технологическая оценка зерна и крупы. Данные биометрического анализа позволяют определить за счет каких признаков формируется продуктивность растения риса, а также установить изменчивость количественных признаков. Критерием степени изменчивости является коэффициент вариации (CV). Изучение среднеспелых короткозерных сортов риса Рапан, Сигнал и Утёс показало, что в условиях конкурсного испытания количественные признаки проявляют различную изменчивость. Сильно и очень сильно варьируют такие признаки, как пустозерность, продуктивная кустистость, масса зерна и соломы с растения (CV от 26 до 55 \%). Средневарьирующими признаками являются количество колосков на метелке, число зерен в метелке, плотность метелки, масса зерна с главной метелки, отношение зерна к соломе (CV от 17 до 24 \%) K слабо варьирующим признакам относятся высота растений, длина главной метелки, коэффициент хозяйственной эффективности фотосинтеза ( $\mathrm{K}_{\text {хо) }}$ (CV 5 - 8 \%). Значения изменчивости признаков необходимо учитывать при оценке и браковке сортов КСИ. По результатам технологической оценки зерна установлены различия между сортами не только по выходу крупы, но и по стоимости полученной продукции с единицы площади. Показаны различия сортов риса Рапан, Сигнал и Утёс по урожайности в рублях с 1 га. В условиях конкурсного испытания сорт Сигнал прибавил к стандарту Рапан на 1 га 22650 руб., а сорт Утёс - 16700 руб.

Ключевые слова: рис, среднеспелые сорта, урожайность, изменчивость количественных признаков, качество крупы.

\section{Введение}

В практике селекционных исследований проводится многолетняя комплексная оценка растений риса по количественным и качественным (альтернативным) признакам. К количественным относят признаки растений, значения которых можно посчитать, измерить, взвесить. Для получения цифровых данных проводят биометрический анализ растений. Например, у риса измеряют высоту растений, длину метелки, подсчитывают количество колосков в метелке, выполненных и стерильных, взвешиванием определяют массу зерна с метелки, с растения и массу 1000 семян, массу соломы с растения и т.д. Важным показателем, позволяющим сравнивать изменчивость разных количественных признаков между собой, является коэффициент вариации (CV) это отношение стандартного отклонения к среднему, выраженное в процентах [3]. По коэффициенту вариации судят о степени изменчивости признаков.

Известно, что продуктивность растений одного и того же сорта при разных условиях выращивания может варьировать в широких пределах [7]. Варьирование признака у растений одного сорта оказывается тем меньшим, чем полнее проявляется признак [1].
Реакция генотипа на изменчивость среды является следствием действия на него отдельных факторов среды [7, 14]. Так, в загущенных посевах угнетается развитие отдельных растений в результате автоконкуренции. Но урожайность (сбор продукции со всей делянки) повышается до определенного загущения, за счет увеличения общего числа стеблей и метелок $[5,16]$. С повышением доз азота от нулевого до оптимального уровня увеличивается урожайность зерна, количество колосков на метелке и выполненных зерен, а также масса 1000 зерен [17, 19]. При превышении оптимального уровня азотного питания значительно повышается высота растений, продуктивная кустистость, возрастает пустозерность, уменьшается масса 1000 зерен и удлиняется вегетационный период $[6,12$, 18, 20].

Изучение изменчивости количественных признаков у пяти разнотипных сортов риса, проведенное в 80-х годах XX в., показало, что это варьирование имеет определенную специфичность. При выращивании сортов риса в семеноводческих питомниках количественные признаки были разделены на 4 группы: 1 - слабоварьирующие (CV до 5 \%): масса 1000 зерен, длина главной метелки, высота расте- 
ний; 2 - средне варьирующие (CV 6-15 \%): плотность метелки, количество колосков на главной метелке, отношения зерна к соломе, масса зерна с главной метелки; 3 - сильно варьирующие (CV 16-25 \%): продуктивная кустистость, масса зерна с растения, масса соломы с растения; 4 - очень сильно варьирующие (CV свыше 25 \%): масса зерна с делянки, пустозерность главной метелки. По результатам исследования был сделан вывод о нецелесообразности проведения отбора по сильноизменчивым признакам, степень проявления которых зависит от условий выращивания [4].

Прошло более 35 лет, российские селекционеры создали новое поколение сортов риса, однако актуальность изучения изменчивости признаков у них не снижается. И в мировом рисоводстве проявляется интерес к этой проблеме. Подтверждением тому являются масштабные исследования, проведенные китайскими учеными в период с 1978 по 2017 гг., по изучению количественных признаков разнотипных сортов риса и связи этих признаков с урожайностью [17].

При изучении длиннозерных сортов риса показано, что для их характеристики важное значение имеет уровень уборочного индекса [7]. Уборочный индекс, или коэффициент хозяйственной эффективности фотосинтеза $\left(\mathrm{K}_{\text {хоз }}\right)$, выражает долю зерна (в \%) в общей надземной массе растений. $\mathrm{K}_{\text {хоз }}$ отражает физиологическую способность растений к мобилизации и использованию всех фотосинтетических продуктов и минеральных веществ при формировании хозяйственно ценной части урожая - зерна. Он является интегральным показателем донорно-акцепторных отношений у растений [8, 11]. Основные успехи селекции зерновых культур на продуктивность многие исследователи связы-

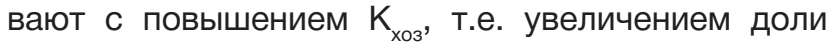
зерна в надземной массе $[9,13]$.

Все это позволяет считать, что $\mathrm{K}_{\text {хоз }}$ является важным признаком зерновой продуктивности сортов. Однако при этом не стоит придавать ему универсальное значение, помня о том, что связь между $\mathrm{K}_{\text {хоз }}$ и урожайностью сортов носит сложный характер. В естественных условиях роста и развития растений $\mathrm{K}_{\text {хоз }}$ подвержен варьированиям в зависимости от уровня минерального питания, густоты стояния побегов, их высоты, воздействия неблагоприятных факторов, поэтому он эффективно может использоваться лишь в оптимальных условиях [2].

Цель исследований

Изучить изменчивость трех среднеспелых со- ртов риса по морфологическим признакам растений в условиях конкурсного испытания (КСИ) для их всесторонней оценки.

\section{Материалы и методы}

Материалом для исследования послужили три среднеспелых короткозерных сорта риса: Рапан, который используется стандартом в КСИ, а также Сигнал и Утёс, проходящие государственное испытание.

Полевые опыты проводили в 2019-2020 гг. на орошаемом участке ФНЦ риса. Подготовку почвы, уход за растениями осуществляли с учетом рекомендаций по возделыванию риса, принятых для зоны [10]. Удобрения вносили из расчета $\mathrm{N}_{120} \mathrm{P}_{90} \mathrm{~K}_{60}$ до посева и $\mathrm{N}_{30}$ в подкормку в фазе растений 3 листа. Водный режим выдерживали согласно варианта укороченного затопления. Посев и залив чека провели 8 мая в 2019 г. и 22 мая в 2020 г.

Для посева сортов риса в конкурсном испытании использовали селекционную сеялку «ВИНТЕРШТАЙГЕР» с центральным высевом. Делянки 8-ми рядковые, с междурядьем 15 см. Площадь делянок 22,5 м² (15 x 1,50). Норма посева 6 млн. всхожих зерен на гектар. Повторность четырехкратная, с рендомизированным размещением делянок. В течение вегетации проводили учеты и наблюдения согласно принятой методики.

Перед уборкой, в фазе полной спелости, в делянках изучаемых сортов отбирали для биометрического анализа по 25 растений с корнями. При этом брали растения подряд в третьем ряду, чтобы снизить действие краевого эффекта от межделяночных дорожек. В лаборатории проводили биометрический анализ растений риса. Полученные данные обрабатывали статистическими методами [3].

\section{Результаты и обсуждение}

Проведенный биометрический анализ растений изучаемых сортов показал, что, несмотря на достаточно оптимальные условия для риса, в делянках конкурсного испытания, среди них наблюдается относительно большое разнообразие. Этому, очевидно, способствует неравномерное распределение семян в ряду при посеве, а также различные микроусловия почвы и неоднородное питание растений в процессе роста и развития. При самой тщательной подготовке чеков к посеву полной почвенной однородности даже в пределах малой площади достичь сложно. Все это отражается на растениях риса и приводит к варьированию количественных признаков. Полученные цифровые данные биометрического анализа растений сортов Рапан, Сигнал и Утёс представлены в таблицах 1, 2, 3. 
Таблица 1. Результаты биометрического анализа сорта Рапан, 2019-2020 гг.

\begin{tabular}{|c|c|c|c|c|c|}
\hline \multirow{2}{*}{\multicolumn{2}{|c|}{ Признаки }} & \multicolumn{4}{|c|}{ Показатели } \\
\hline & & Средняя & Максимум & Минимум & $\begin{array}{c}\text { Коэффициент } \\
\text { вариации (CV), \% }\end{array}$ \\
\hline \multicolumn{2}{|c|}{ Высота растений, см } & 89,1 & 95 & 81 & 5 \\
\hline \multicolumn{2}{|c|}{ Число продуктивных стеблей, шт./раст. } & 2,7 & 4 & 1 & 28 \\
\hline \multirow{6}{*}{$\begin{array}{l}\text { Главная } \\
\text { метелка }\end{array}$} & длина, см & 17,6 & 20,5 & 14 & 9 \\
\hline & общее число колосков, шт. & 226,3 & 333 & 153 & 16 \\
\hline & выполненных зерен, шт. & 193,0 & 269 & 129 & 16 \\
\hline & пустых колосков, шт. & 33,3 & 64 & 6 & 55 \\
\hline & пустозерность, \% & 14,5 & 29,6 & 2,6 & 51 \\
\hline & плотность, шт./см & 14,0 & 18 & 8 & 18 \\
\hline \multirow{3}{*}{ Macca } & зерна с гл. метелки, г & 4,6 & 6,0 & 2,9 & 17 \\
\hline & зерна с растения, г & 9,9 & 19,0 & 4,0 & 38 \\
\hline & соломы с растения, г & 7,8 & 15,3 & 2,3 & 43 \\
\hline \multicolumn{2}{|c|}{ Отношение зерна к соломе, 1: } & 0,77 & 0,95 & 0,58 & 17 \\
\hline \multicolumn{2}{|c|}{$\mathrm{K}_{\text {хоз, }} \%$} & 56,7 & 66,2 & 51,1 & 8 \\
\hline \multicolumn{2}{|c|}{ Озерненность агрофитоценоза, зерен/м² } & \multicolumn{4}{|l|}{38383} \\
\hline \multicolumn{2}{|c|}{ Продуктивность агрофитоценоза, г/ м² } & \multicolumn{4}{|l|}{1112} \\
\hline
\end{tabular}

Как видно из таблицы 1, сорт риса Рапан очень хорошо выровнен по высоте растений и длине метелки. Об этом свидетельствует незначительный разброс данных от среднего показателя и подтверждается низким коэффициентом вариации. CV по этим признакам равен 5 и 9 \% соответственно. Это низко варьирующие признаки.

Сорт Рапан имеет достаточно высокую озерненность метелок: в среднем по 226 колосков на метелке. При отличии от средней 153 - 333 шт., CV составляет $16 \%$. Это позволяет отнести этот признак к средневарьирующим. Таковыми по изменчивости являются также число выполненных зерен, масса зерна с главной метелки, плотность метелки. У этих признаков CV равен 16 - $18 \%$.

Остальные изученные количественные признаки у этого сорта являются сильно варьирующими. Различия по числу продуктивных стеблей (продуктивная кустистость) наблюдались между растениями от 1 до 4. При этом CV составил 28 \%. Еще большая изменчивость была по массе зерна и соломы с растения, CV - 38 и 43 \% соответственно. Максимальная изменчивость между растениями сорта Рапан была по числу пустых колосков в метелке, и, как следствие, пустозерности. Различия по этим признакам между растениями превышали значения в 10 раз. Поэтому и CV был очень высок - 51-55 \%.

Расчетный показатель «отношение зерна к соломе» относится к группе средневарьирующих признаков, CV - 17 \%. Еще меньше изменчивость по коэффициенту хозяйственной эффективности фотосинтеза или уборочному индексу. CV по К составил 8 \%. Этот показатель является хорошим критерием для селекционной оценки сортов риса.

Практически аналогичные результаты мы наблюдаем и по сорту риса Сигнал, хотя в абсолютном выражении имеются некоторые отличия по сравнению с сортом Рапан (табл. 2).

Таблица 2. Результаты биометрического анализа сорта Сигнал, 2019-2020 гг.

\begin{tabular}{|c|c|c|c|c|c|}
\hline \multirow{2}{*}{\multicolumn{2}{|c|}{ Признаки }} & \multicolumn{4}{|c|}{ Показатели } \\
\hline & & Средняя & Максимум & Минимум & $\begin{array}{c}\text { Коэффициент } \\
\text { вариации (CV), \% }\end{array}$ \\
\hline \multicolumn{2}{|c|}{ Высота растений, см } & 88,1 & 95 & 80 & 7 \\
\hline \multicolumn{2}{|c|}{ Число продуктивных стеблей, шт./ раст. } & 2,5 & 4 & 1 & 30 \\
\hline \multirow{6}{*}{$\begin{array}{l}\text { Главная } \\
\text { метелка }\end{array}$} & длина, см & 17,0 & 20,0 & 13 & 7 \\
\hline & общее число колосков, шт. & 209,3 & 319 & 109 & 17 \\
\hline & выполненных зерен, шт. & 184,8 & 275 & 90 & 22 \\
\hline & пустых колосков, шт. & 24,4 & 57 & 4 & 44 \\
\hline & пустозерность, \% & 11,4 & 20,4 & 2,0 & 50 \\
\hline & плотность, шт./см & 11,6 & 15 & 7 & 22 \\
\hline \multirow{3}{*}{ Macca } & зерна с гл. метелки, г & 4,5 & 6,2 & 2,5 & 26 \\
\hline & зерна с растения, г & 9,0 & 18,3 & 2,5 & 42 \\
\hline & соломы с растения, г & 7,7 & 17,0 & 2,1 & 41 \\
\hline \multicolumn{2}{|c|}{ Отношение зерна к соломе, 1: } & 0,83 & 1,21 & 0,46 & 18 \\
\hline \multicolumn{2}{|c|}{$\mathrm{K}_{\mathrm{xo3},} \%$} & 55,0 & 68,3 & 45,2 & 8 \\
\hline \multicolumn{2}{|c|}{ Озерненность агрофитоценоза, зерен/м² } & \multicolumn{4}{|l|}{39591} \\
\hline \multicolumn{2}{|c|}{ Продуктивность агрофитоценоза, г/ м² } & \multicolumn{4}{|l|}{1148} \\
\hline
\end{tabular}


У сорта Сигнал к маловарьрующим признакам относятся высота растений и длина главной ме-

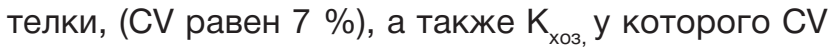
- 8 \%. Средневарьирующими признаками оказались общее число колосков на главной метелке и отношение зерна к соломе, у которых CV coставил 17 и $18 \%$ соответственно. Значительно больший разброс от среднего показателя у сорта Сигнал по сравнению с сортом Рапан по таким признакам, как «число выполненных зерен в метелке», «плотность метелки» и «масса зерна с ме- телки» (CV равен 22, 22 и 26 \%). Еще больший коэффициент вариации получен по признакам «масса зерна» и «масса соломы» с растения, а также признаку «число пустых колосков в метелке», при этом CV составляет 42, 41 и 44 \% соответственно. Максимальный показатель CV - 50 \% отмечен у сорта Сигнал по расчетному признаку пустозерности метелки. При анализе растений сорта Утёс выявлены практически те же закономерности, как у сортов Рапан и Сигнал, хотя наблюдались и некоторые отличия (табл. 3).

Таблица 3. Результаты биометрического анализа сорта Утёс, 2019-2020 гг.

\begin{tabular}{|c|c|c|c|c|c|}
\hline \multirow{2}{*}{\multicolumn{2}{|c|}{ Признаки }} & \multicolumn{4}{|c|}{ Показатели } \\
\hline & & Средняя & Максимум & Минимум & $\begin{array}{c}\text { Коэффициент } \\
\text { вариации (CV), \% }\end{array}$ \\
\hline \multicolumn{2}{|c|}{ Высота растений, см } & 81,6 & 93 & 73 & 7 \\
\hline \multicolumn{2}{|c|}{ Число продуктивных стеблей, шт./ раст. } & 2,8 & 4 & 1 & 30 \\
\hline \multirow{6}{*}{$\begin{array}{l}\text { Главная } \\
\text { метелка }\end{array}$} & длина, см & 15,2 & 18 & 13 & 7 \\
\hline & общее число колосков, шт. & 137,3 & 213 & 70 & 17 \\
\hline & выполненных зерен, шт. & 118,0 & 187 & 52 & 22 \\
\hline & пустых колосков, шт. & 19,7 & 33 & 4 & 44 \\
\hline & пустозерность, \% & 14,9 & 27 & 3 & 50 \\
\hline & плотность, шт./см & 12,4 & 21 & 8 & 22 \\
\hline \multirow{3}{*}{ Macca } & зерна с гл. метелки, г & 3,5 & 6,2 & 2,0 & 26 \\
\hline & зерна с растения, г & 7,6 & 15,5 & 2,0 & 42 \\
\hline & соломы с растения, г & 6,9 & 11,0 & 1,3 & 41 \\
\hline \multicolumn{2}{|c|}{ Отношение зерна к соломе, 1 : } & 0,89 & 1,42 & 0,67 & 25 \\
\hline \multicolumn{2}{|c|}{$\mathrm{K}_{\mathrm{xоз},} \%$} & 53,0 & 60,6 & 41,1 & 11 \\
\hline \multicolumn{2}{|c|}{ Озерненность агрофитоценоза, зерен/м² } & \multicolumn{4}{|l|}{39960} \\
\hline \multicolumn{2}{|c|}{ Продуктивность агрофитоценоза, г/ м² } & \multicolumn{4}{|l|}{1159} \\
\hline
\end{tabular}

Как видно из таблицы 3, признаки высоты растений и длины главной метелки вошли в группу мало изменчивых признаков (CV - 7 \%). Средне измен-

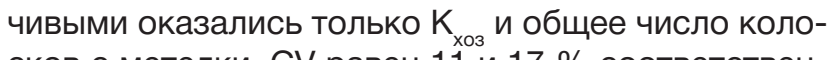
сков с метелки, CV равен 11 и 17 \% соответственно. Число выполненных зерен, плотность метелки, отношение зерна к соломе и масса зерна с главной метелки вошли в группу сильноизменчивых признаков (CV - 22-26 \%). Наиболее изменчивыми, очень сильноварьирующими у сорта Утёс оказались признаки «масса зерна» и «масса соломы» с растения, «число пустых колосков в главной метелке» и «пустозерность» (CV - 41-50 \%). Из этого следует, что растения сорта Утёс по сравнению с другими сортами сильнее реагируют на самые незначительные изменения в условиях среды в период вегетации.

Изученные сорта различались по важному агрономическому признаку - «озерненность агрофитоценоза»: первым оказался сорт Утёс - 39960 зерен/м², затем Сигнал и Рапан, которые имели соответственно 39591 и 38383 зерен/м². Это предопределило уро- вень их биологической урожайности или «продуктивность агрофитоценоза».

Результирующим показателем оценки сортов риса является урожайность и качество продукции, а также ее стоимость. Как известно, урожайность риса складывается из продуктивности растения и количества продуктивных метелок на единице площади. Изучаемые сорта различались по этим показателям. Так, у сорта Рапан перед уборкой сохранилось в среднем 227 метелок на 1 м², у сорта Сигнал249 метелок/ м², а у сорта Утёс - 333 метелки/ м². Это в итоге и предопределило конечную урожайность этих сортов. Для полной оценки сорта важна стоимость его урожая. Чтобы всесторонне оценить изученные сорта, мы посчитали стоимость урожая риса-сырца, крупы и в результате определили урожайность каждого сорта в рублях с 1 га. Для расчета была взята средняя цена в 2020 г.: риса-сырца - 22 тыс. руб. за 1 тонну, крупы 1-го сорта 40 тыс. руб./т, крупы-дробленки - 25 тыс. руб./т. Полученные данные по урожайности и расчетные показатели стоимости представлены в таблице 4. 
Таблица 4. Урожайность зерна и его стоимость у среднеспелых короткозерных сортов риса, 2020 r.

\begin{tabular}{|l|c|c|c|}
\hline \multicolumn{1}{|c|}{ Показатели } & \multicolumn{2}{c|}{ Сорт } \\
\cline { 2 - 4 } & Рапан, ст. & Сигнал & Утёс \\
\hline Урожайность зерна, т/га & 8,46 & 8,96 & 8,98 \\
\hline Стоимость урожая - сырца, руб./га & 186120 & 197120 & 197560 \\
\hline Прибавка к стандарту, руб./га & - & 11000 & 71440 \\
\hline Общий выход крупы, \% & 71,4 & 72,2 & 71,8 \\
\hline - в т. ч. целого ядра, \% & 84,7 & 90,6 & 86,1 \\
\hline - в т.ч. дробленки, \% & 15,3 & 9,4 & 13,9 \\
\hline Урожайность в крупе, т/га & 6,04 & 6,49 & 6,45 \\
\hline - в т.ч. целого ядра, т/га & 5,12 & 5,88 & 5,55 \\
\hline - в т.ч. дробленки, т/га & 0,92 & 0,61 & 0,90 \\
\hline Стоимость урожая крупы 1-го сорта, руб. & 204800 & 235200 & 222000 \\
\hline Стоимость полученной дробленки, руб. & 23000 & 15250 & 22500 \\
\hline Общий доход от крупы, урожайность в руб. с 1 га. & 227800 & 250450 & 244500 \\
\hline Прибавка к стандарту, руб./га & - & 22650 & 16700 \\
\hline Разница в доходе от крупы и сырца, руб. & 41680 & 53330 & 46940 \\
\hline
\end{tabular}

По урожайности сорта Сигнал и Утёс превысили стандарт Рапан на 0,50 и 0,52 т/га соответственно. При реализации риса сырца сорт Сигнал дал дополнительно 11000 рублей с 1 га, а сорт Утёс - 11440 руб./га по сравнению с сортом Рапан. Однако при продаже крупы, несмотря на затраты на переработку, получаемый доход значительно выше, чем при продаже риса-сырца. Из таблицы 4 видно, что разница в доходе от реализации крупы риса и риса-сырца у сортов составляет: Рапан - 41680 руб., Сигнал - 53330 руб., Утёс - 46940 руб. Учитывая, что сорта имеют разный выход крупы, включая целое ядро и дробленку, различия между ними в урожайности, выраженной в рублях с гектара, значительно возрастают. По результатам опыта в условиях конкурсного испытания сорт Сигнал прибавил к стандарту на 1 га 22650 руб., а сорт Утёс - 16700 руб. Из этого следует, что новые сорта риса необходимо оценивать не только по урожайности, но и по стоимости конечной продукции в расчете на 1 га.

\section{Выводы}

1. Количественные признаки среднеспелых короткозерных сортов риса Рапан, Сигнал и Утёс в условиях конкурсного испытания проявляют различную изменчивость. Сильно и очень сильно варьируют такие признаки, как пустозерность, продуктивная кустистость, масса зерна и соломы с растения. Средневарьирующими признаками являются количество колосков на метелке, число зерен в метелке, плотность метелки, масса зерна с главной метелки, отношение зерна к соломе. К слабо варьирующим признакам относятся высота растений, длина главной метелки, коэффициент хозяйственной эффективности фотосинтеза $\left(\mathrm{K}_{\mathrm{x03} .}\right)$.

2. При оценке сортов риса в конкурсном испытании целесообразно учитывать не только урожайность зерна, качество крупы, но и стоимость конечной продукции в рублях с 1 га.

\section{ЛИТЕРАТУРА}

1. Берлянд-Кожевников, В.М. Возможности использования коэффициента вариации для анализа количественных признаков у растений / В.М. Берлянд-Кожевников // Успехи биометрии, Л.: Изд-во Ленинградского ун-та, 1975. - Т. XXII. - Вып. 5. - С. 34-45.

2. Воробьев, Н.В. Изменения в системе донорно-акцепторных отношений у риса в процессе селекции на продуктивность. Обзор / Н.В. Воробьев, В.С. Ковалев, М.А. Скаженник // Рисоводство. - 2006. - № 9. - С. 13-17.

3. Доспехов, Б. А. Методика полевого опыта (с основами статистической обработки результатов исследований): учеб. для высш. с.-х. учеб. заведений / Б. А. Доспехов. - изд. 5-е., доп. и перераб. стер. изд. - М.: Альянс, 2014. - $351 \mathrm{c}$.

4. Зеленский, Г.Л. Внутрисортовая изменчивость и методы первичного семеноводства сортов риса интенсивного типа / Г.Л. Зеленский // Автореф. дисс...канд. с.-х. наук. - Краснодар, 1985. - 25 с.

5. Зеленский, Г.Л. Реакция форм риса с эректоидными листьями на загущение / Г.Л. Зеленский, И.И. Бегун, А.Г. Зеленский // Рисоводство. - 2005. - № 7. - С. 21-25.

6. Зеленский, Г.Л. Сорт - технология - пирикуляриоз / Г.Л. Зеленский // Агроснабфорум. - Краснодар, 2010. №10 (80). - С. 28-29.

7. Зеленский, Г.Л. Изменчивость количественных признаков длиннозерных сортов риса в зависимости от условий среды / Г.Л. Зеленский, О.В. Зеленская, К.Ю. Кобинякова // Рисоводство. - 2020. - № 4 (49). - С. 6-10.

8. Кумаков, В.А. Фотосинтетическая деятельность растений в аспекте селекции / В.А. Кумаков // Физиология фотосинтеза. - М.: Наука, 1982. - С. 283-293.

9. Лукьяненко, П.П. О селекции низкостебельных сортов озимой пшеницы / П.П. Лукьяненко // Селекция и семеноводство. - 1971. - № 2. - С. 12-19. 
10. Система рисоводства Краснодарского края / под ред. Е. М. Харитонова. - Краснодар, 2011. - 316 с.

11. Angelini, R. II riso / R. Angelini, A. Ferrero, I. Ponti. - Milano: Bayer Crop Science, 2008. - 680 p.

12. Bhosale, R.J. Effect of spacing and nitrogen levels of yield of rice / R.J. Bhosale, S.N. Jadhav, B.P. Patil // J. Maharashtra Agr. Univ., 1985. - V. 8. - № 2. - P. 116-117.

13. Fageria, N.K. Yield and yield components of upland rice as influenced by nitrogen sources / N.K. Fageria, A. Moreira, A.M. Coelho // Journal of Plant Nutrition. - 2011. - V. 34. - Is. 3. - P. 361-370. DOI: 10.1080/01904167.2011.536878

14. Hittalmani, S. Identification of QTL for growth and grain yield-related traits in rice across nine locations of Asia / S. Hittalmani, N. Huang, B. Courtois, R. Venuprasad, H.E. Shashidhar, J-Y. Zhuang, K-L. Zheng, G-F. Liu, G-C. Wang, J.S. Sidhu, S. Srivantaneeyakul, V.P. Singh, P.G. Bagali, H.C. Prasanna, G. Mc Laren, G.S. Khush // Theor. Appl. Genet. - 2003. - V. 107. - P. 679-690. DOI 10.1007/s00122-003-1269-1

15. Jana, P.K. Performance of rice varieties to levels of nitrogen and methods of planting / P.K. Jana, S.E. Haldar, R.C. Samul, B.D. Mandal // Food Farm. and Agr. - 1981. - V. 13. - № 11-12. - P. 196-197.

16. Lerch, G. Einfluss einiger klma und anbaufaktoren unddie ertragebildung der reissorte "IR-8" in Cuba. I Standanwiets und Stickstoffsdundung / G. Lerch. // Kulturpflanse. - 1976. - P. 13-51.

17. Li, R. Exploring the relationships between yield and yield-related traits for rice varieties released in China from 1978 to 2017 / R. Li, M. Li, U. Ashraf, S. Liu, J. Zhang // Front. Plant Sci. - 2019. - V. 10. - 543 p. DOI: 10.3389/fpls.2019.00543.

18. Murty, P.S. Spikelet sterility in relation to nitrogen and carbohydrate contents in rice / P.S. Murty, K.S. Murty // Indian J. Plant Physiol. - 1982. - V. 25. - № 1. - P. 40-48.

19. Pan, S. Effects of $\mathrm{N}$ management on yield and $\mathrm{N}$ uptake of rice in Central China / S. Pan, S. Huang, J. Zhai, J. Wang, C. Cao, M. Cai, M. Zhan, X. Tang // Journal of Integrative Agriculture. - 2012. - V. 11. - Is.12. - P.1993-2000. DOI: 10.1016/ S2095-3119(12)60456-0.

20. Sui, B. Optimizing nitrogen supply increases rice yield and nitrogen use efficiency by regulating yield formation factors / B. Sui, X. Feng, G. Tian, X. Hu, Q. Shen, S. Guo // Field Crops Research. - 2013. - V. 150. - P. 99-107. DOI: 10.1016/j.fcr.2013.06.012.

\section{REFERENCES}

1. Berlyand-Kozhevnikov, V.M. Possibilities of using the coefficient of variation for the analysis of quantitative traits in plants / V.M. Berlyand-Kozhevnikov // Advances in biometrics, L .: Publishing house of Leningrad University, 1975. - T. XXII. - Issue. 5. - P. 34-45.

2. Vorobiev, N.V. Changes in the system of donor-acceptor relations in rice during breeding for productivity. Review / N.V. Vorobiev, V.S. Kovalev, M.A. Skazhennik // Rice growing. - 2006. - № 9. - P. 13-17.

3. Dospekhov, BA Method of field experiment (with the basics of statistical processing of research results): textbook. for higher education agricultural institutions / B. A. Dospekhov. - ed. 5th., revised and enlarged - M .: Alliance, 2014 .- 351 p.

4. Zelensky, G.L. Intravarietal variability and methods of primary seed production of rice varieties of intensive type / G.L. Zelensky // Abstract of Ph.D. thesis - Krasnodar, 1985 .- 25 p.

5. Zelensky, G.L. Reaction of rice forms with erectoid leaves to thickening / G.L. Zelensky, I.I. Begun, A.G. Zelensky // Rice farming. - 2005. - № 7. - P. 21-25.

6. Zelensky, G.L. Variety - technology - blast / G.L. Zelensky // Agrosnabforum. - Krasnodar, 2010. - № 10 (80). - P. 28-29.

7. Zelensky, G.L. Variability of quantitative traits of long-grain rice varieties depending on environmental conditions / G.L. Zelensky, O. V. Zelenskaya, K.Yu. Kobinyakova // Rice growing. - 2020. - № 4 (49). - P. 6-10.

8. Kumakov, V.A. Photosynthetic activity of plants in the aspect of breeding / V.A. Kumakov // Physiology of photosynthesis. - M.: Nauka, 1982 .- P. 283-293.

9. Lukyanenko, P.P. Breeding of low-stemmed winter wheat varieties / P.P. Lukyanenko // Breeding and seed production. - 1971. - № 2. - P. 12-19.

10. Rice growing system of Krasnodar region / under editorship of E. M. Kharitonov - Krasnodar, 2011 .- 316 p.

11. Angelini, R. II riso / R. Angelini, A. Ferrero, I. Ponti. - Milano: Bayer Crop Science, 2008. - 680 p.

12. Bhosale, R.J. Effect of spacing and nitrogen levels of yield of rice / R.J. Bhosale, S.N. Jadhav, B.P. Patil // J. Maharashtra Agr. Univ., 1985. - V. 8. - № 2. - P. 116-117.

13. Fageria, N.K. Yield and yield components of upland rice as influenced by nitrogen sources / N.K. Fageria, A. Moreira, A.M. Coelho // Journal of Plant Nutrition. - 2011. - V. 34. - Is. 3. - P. 361-370. DOI: 10.1080/01904167.2011.536878

14. Hittalmani, S. Identification of QTL for growth and grain yield-related traits in rice across nine locations of Asia / S. Hittalmani, N. Huang, B. Courtois, R. Venuprasad, H.E. Shashidhar, J-Y. Zhuang, K-L. Zheng, G-F. Liu, G-C. Wang, J.S. Sidhu, S. Srivantaneeyakul, V.P. Singh, P.G. Bagali, H.C. Prasanna, G. Mc Laren, G.S. Khush // Theor. Appl. Genet. - 2003. - V. 107. - P. 679-690. DOI 10.1007/s00122-003-1269-1

15. Jana, P.K. Performance of rice varieties to levels of nitrogen and methods of planting / P.K. Jana, S.E. Haldar, R.C. Samul, B.D. Mandal // Food Farm. and Agr. - 1981. - V. 13. - № 11-12. - P. 196-197.

16. Lerch, G. Einfluss einiger klma und anbaufaktoren unddie ertragebildung der reissorte "IR-8" in Cuba. I Standanwiets und Stickstoffsdundung / G. Lerch. // Kulturpflanse. - 1976. - P. 13-51.

17. Li, R. Exploring the relationships between yield and yield-related traits for rice varieties released in China from 1978 to 2017 / R. Li, M. Li, U. Ashraf, S. Liu, J. Zhang // Front. Plant Sci. - 2019. - V. 10. - 543 p. DOI: 10.3389/fpls.2019.00543.

18. Murty, P.S. Spikelet sterility in relation to nitrogen and carbohydrate contents in rice / P.S. Murty, K.S. Murty // Indian J. Plant Physiol. - 1982. - V. 25. - № 1. - P. 40-48.

19. Pan, S. Effects of $\mathrm{N}$ management on yield and $\mathrm{N}$ uptake of rice in Central China / S. Pan, S. Huang, J. Zhai, J. Wang, 
C. Cao, M. Cai, M. Zhan, X. Tang // Journal of Integrative Agriculture. - 2012. - V. 11. - Is.12. - P.1993-2000. DOI: 10.1016/ S2095-3119(12)60456-0.

20. Sui, B. Optimizing nitrogen supply increases rice yield and nitrogen use efficiency by regulating yield formation factors / B. Sui, X. Feng, G. Tian, X. Hu, Q. Shen, S. Guo // Field Crops Research. - 2013. - V. 150. - P. 99-107. DOI: 10.1016/j.fcr.2013.06.012.

\section{Зеленский Алексей Григорьевич}

Старший научный сотрудник отдела селекции

E-mail: odin165@mail.ru

\section{Гненный Евгений Юрьевич}

младший научный сотрудник отдела селекции E-mail: g.gheka@gmail.com

\section{Зеленский Григорий Леонидович}

Главный научный сотрудник отдела селекции

E-mail: zelensky08@mail.ru

Bce: ФГБНУ «ФНЦ» риса, 350921, Россия,

г. Краснодар, Белозерный, 3

\section{Zelensky Alexey Grigorievich}

Senior researcher of the breeding department

E-mail:odin165@mail.ru

\section{Gnennyy Evgeny Yurievich}

Junior researcher of the breeding department E-mail: g.gheka@gmail.com

\section{Zelensky Grigory Leonidovich.}

Chief researcher of the breeding department E-mail: zelensky08@mail.ru

All: $\mathrm{FSBSI}$ «FNC of rice»

3, Belozerny, Krasnodar, 350921, Russia 


\section{ПРОЯВЛЕНИЕ КРАЕВОГО ЭФФЕКТА В МЕЛКОДЕЛЯНОЧНЫХ ОПЫТАХ И СПОСОБЫ ЕГО УЧЁТА}

Изучено проявление краевого эффекта в мелкоделяночных опытах на примере сортов риса Фаворит, Рапан, Юбилейный-85, Альянс и сортообразцах конкурсного испытания ВНИИР 6524, ВНИИР 7146, ВНИИР 7099. Установлены существенные различия по массе зерна с крайних рядков в восьмирядковой делянке на всех сортах и сортообразцах, что подтверждается результатами трёхфакторного дисперсионного анализа. Доля влияния расположения рядка (номера рядка) составила 83,1 \%, погодных условий - 3,3 \%, по сортам различия не существенны. В среднем за два года исследований масса зерна с крайних рядков составила 286,3 г/пог. м, а рядков не испытывающих краевого эффекта 151,6 г/пог. м. Прибавка зерна крайних рядков к среднестатистическому рядку составила 134,6 г/пог. м. Доля вклада краевого эффекта в общий урожай зерна с делянки в среднем составляет 18,2 - 20,7 \%, а прибавка массы зерна с крайних рядков по отношению к среднестатистическому рядку в делянке 89 - 103 \%, то есть крайние рядки в восьмирядковой делянке формируют массу зерна равную четырём рядкам не подверженным краевому эффекту. Урожайность сортообразцов риса конкурсного сортоиспытания при пересчёте с восьмирядковой делянки на один гектар, в среднем составила 108,7 ц/га зерна риса, а при исключении из расчёта двух крайних рядков - 86, 1 ц/га, что на 22,6 ц/га или 20,8 \% меньше. Для учёта краевого эффекта в восьмирядковой делянке, при пересчёте урожайности на 1 га, следует применять поправочный коэффициент 0,8, либо использовать при расчётах учётной площади делянки, увеличенной на два междурядья ширины делянки ((8+2) х 0,15 м = $1,5 \mathrm{M})$.

Ключевые слова: рис, сорт, делянка, краевой эффект, рядок, урожайность, продуктивность.

\section{MANIFESTATION OF THE EDGE EFFECT IN SMALL-PLOT EXPERIMENTS AND METHODS OF TAKING IT INTO ACCOUNT}

The manifestation of the edge effect in small-plot experiments was studied using the example of rice varieties Favorit, Rapan, Yubileiny-85, Alliance and accessions of competitive testing VNIIR 6524, VNIIR 7146, VNIIR 7099. Significant differences in the productivity of the edging rows in an eight-row plot on all varieties and accessions were established, which is confirmed by the results of three-way analysis of variance. The share of the influence of the location of the row (row number) was $83.1 \%$, weather conditions - 3.3\%, and the differences in varieties are not significant. On average, over two years of research, the mass of grain from the edging rows was $286.3 \mathrm{~g} /$ linear $\mathrm{m}$, and rows not experiencing the edge effect $151.6 \mathrm{~g} /$ linear $\mathrm{m}$. The increase in grain from the edging rows to the average row was $134.6 \mathrm{~g} /$ linear $\mathrm{m}$. The share of the contribution of the edge effect to the total grain yield from the plot is on average $18.2-20.7 \%$, and the increase in the edging rows in relation to the average row in the plot is $89-103 \%$, i.e. edging rows in an eight-row plot form a productivity equal to 4 rows not subject to the edge effect. The yield of rice accessions of competitive variety testing, calculated from an eight-row plot per hectare, averaged $108.7 \mathrm{c} /$ ha of rice grain, and with the exclusion of two edging rows from the calculation - $86.1 \mathrm{c} / \mathrm{ha}$, which is $22.6 \mathrm{c} / \mathrm{ha}$. or $20.8 \%$ less. To take into account the edge effect in an eight-row plot, when recalculating the yield per hectare, a correction factor of 0.8 should be used, or the use of the accounting area of the plot increased by two row spacings of the plot width $((8+2) \times 0.15 \mathrm{~m}=1.5 \mathrm{~m})$.

Key words: rice, variety, plot, edge effect, row, yield, productivity.

\section{Введение}

Получение объективных результатов полевых опытов, является важнейшей задачей селекционеров и сортоиспытателей. Достижение этой цели во многом зависит от правильности закладки полевых опытов и учёта факторов, искажающих их результаты. К таким факторам, наряду с пестротой почвенного плодородия, случайными техническими 
ошибками, относится «краевой эффект», затрудняющий идентификацию и отбор хозяйственно-ценных генотипов. Он проявляется главным образом в модификационной изменчивости растений, произрастающих в крайних рядках делянок $[1,5,6,8$, $9,12]$. Большая площадь питания (за счёт дорожки), лучшая освещённость и беспрепятственный газообмен растений, произрастающих в крайних рядках, дают им существенные преимущества, в сравнении с растениями внутри делянки, при этом продуктивность растений подверженных краевому эффекту выше, по отношению к растениям, не испытывающим его [3]. В исследованиях установлены значительные расхождения результатов оценок в селекционном питомнике и конкурсном испытании, что связано с большими различиями условий произрастания растений в опытах [7]. По данным в десятирядных делянках конкурсного испытания с дорожками 60 см превышение продуктивности растений краевых рядков над растениями средних рядков для озимой и яровой пшеницы варьировало в пределах 60-160 \%, для проса - 110-170 \%, гороха - 60-137 \% [10]. В других исследованиях установлено, что на делянках яровой пшеницы краевой эффект распространяется вглубь делянки на расстоянии 20 - 25 см и, при часто применяемой в селекционных исследованиях ширине делянки 1 м, около 40 \% растений оказываются в зоне его влияния [8]. На восьмирядковых делянках ячменя и пшеницы, показано, что два крайних рядка дали урожай на 40 \% выше двух срединных, а растения с 30-сантиметровых концов делянок (с торцов) были урожайней на 30 \% растений из центра [15].

В Федеральном научном центре риса конкурсное и экологическое сортоиспытание закладывается восьмирядковыми делянками, площадью 18-25 м 2 в четырёхкратной повторности, что обеспечивает более высокую точность оценок генотипов в сравнении с предыдущими звеньями селекционного процесса (контрольный и селекционный питомники) [3]. Наряду с опытами по конкурсному и экологическому сортоиспытанию проводится и производственная проверка новых сортов риса на делянках от 0,1 до 1,0 га, главной целью которой является выявление наиболее урожайных генотипов. Как показывает практика, урожайность одних и тех же генотипов в экологическом и производственном испытаниях, при выращивании на одном поле, неодинакова. В ранее проведённых исследованиях урожайность в опыте по экологическому сортоиспытанию была в среднем выше на 23,5 \%, чем в производственном [12].
Для элиминации краевого эффекта предлагается использовать делянки квадратной формы и исключать краевые рядки [8].

Цель исследований

Изучить влияние краевого эффекта на урожайность сортов риса в мелкоделяночных опытах.

\section{Материалы и методы}

Исследования проводили в 2018-2020 гг., на 4 сортах риса (Рапан, Фаворит, Альянс, Юбилейный-85) и 3 сортообразцах конкурсного испытания (ВНИИР 6524, ВНИИР 7146, ВНИИР 7099). Опыты закладывали на опытно-производственном участке ФНЦ риса и в ФГБУ ЭСОС «Красная» (в 2020 г.) по предшественникам рис (2018 г.), соя (2019 г.), мн. травы (2020 г.). Пос ев делянок осуществляли по методике конкурсного сортоиспытания, нормой 7 млн. всхожих зёрен на гектар, в четырёхкратной повторности, восьмирядковыми делянками

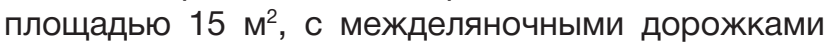
40 см [3, 13]. Для учёта массы зерна с 1 погонного метра рядка выжинали по 2 метра каждого рядка на делянках сортов в 4-кратной повторности. Сжатые снопы обмолачивали на стационарной молотилке, а полученное зерно взвешивали, определяли его влажность и пересчитывали урожай на стандартную влажность. В 2020 году на делянках трёх образцов риса конкурсного испытания полностью сжали крайние рядки длиной 12,5 м, после прохода комбайна по делянке с 6 рядками, через комбайн пропускали отдельно сжатые снопы. После обмолота снопов и делянок зерно взвешивали и определяли его влажность, пересчитывали урожайность на стандартную влажность. Статистическую обработку результатов исследований проводили методом дисперсионного анализа по Б.А. Доспехову с помощью программ Statistica 6.0 и MS Office Excel 2010 [2].

\section{Результаты и обсуждение}

Проведёнными исследованиями установлены существенные различия массы зерна, формируемой крайними рядками ваосьмирядковой делянки, в сравнении с остальными рядками на всех сортах, что подтверждается результатами трёхфакторного дисперсионного анализа (табл. 1). Фактический критерий Фишера (Fфакт.) по факторам A (год) и В (номер рядка) выше табличных значений, при этом наибольшее влияние на варьирование массы зерна с рядка оказывает номер рядка, а именно повышенная урожайность 1 и 8 рядков (83,1 \%). Влияние погодных условий 3,3 \% (фактор А). Сорта не оказали существенного влияния на массу зерна с рядка (Ғфакт. < Fтаб.). 
Таблица 1. Результаты трёхфакторного дисперсионного анализа полевого опыта по изучению краевого эффекта, 2018-2019 гг.

\begin{tabular}{|l|c|c|c|c|c|c|}
\hline \multicolumn{1}{|c|}{ Источник вариации } & $\begin{array}{c}\text { Сумма } \\
\text { квадратов }\end{array}$ & $\begin{array}{c}\text { Степени } \\
\text { свободы }\end{array}$ & Дисперсия & F факт. & F табл. & Влияние, \% \\
\hline Фактор А (год) & 33193,0 & 1,0 & 33193,0 & 87,2 & 3,9 & 3,3 \\
\hline Фактор В (номер рядка) & 825793,0 & 7,0 & 117970,4 & 310,0 & 2,1 & 83,1 \\
\hline Фактор С (сорт) & 1112,0 & 3,0 & 370,7 & 1,0 & 2,7 & 0,1 \\
\hline $\begin{array}{l}\text { Взаимодействие АВ } \\
\text { (год - номер рядка) }\end{array}$ & 7584,0 & 7,0 & 1083,4 & 2,8 & 2,1 & 0,8 \\
\hline $\begin{array}{l}\text { Взаимодействие АС } \\
\text { (год - сорт) }\end{array}$ & 15612,0 & 3,0 & 5204,0 & 13,7 & 2,7 & 1,6 \\
\hline $\begin{array}{l}\text { Взаимодействие ВС } \\
\text { (номер рядка - сорт) }\end{array}$ & 19244,0 & 21,0 & 916,4 & 2,4 & 1,6 & 1,9 \\
\hline $\begin{array}{l}\text { Взаимодействие АВС } \\
\text { (год - номер рядка - сорт) }\end{array}$ & 12865,0 & 21,0 & 612,6 & 1,6 & 1,6 & 1,3 \\
\hline
\end{tabular}

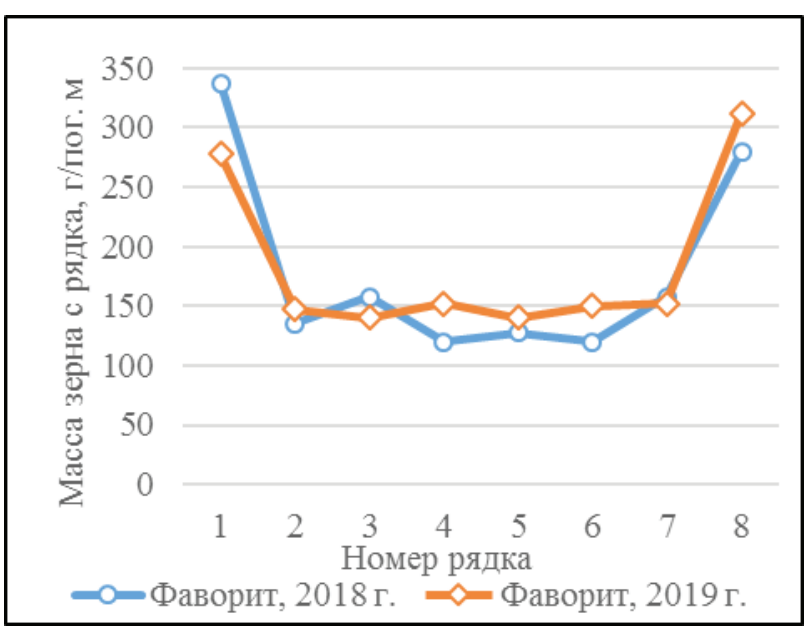

Фаворит

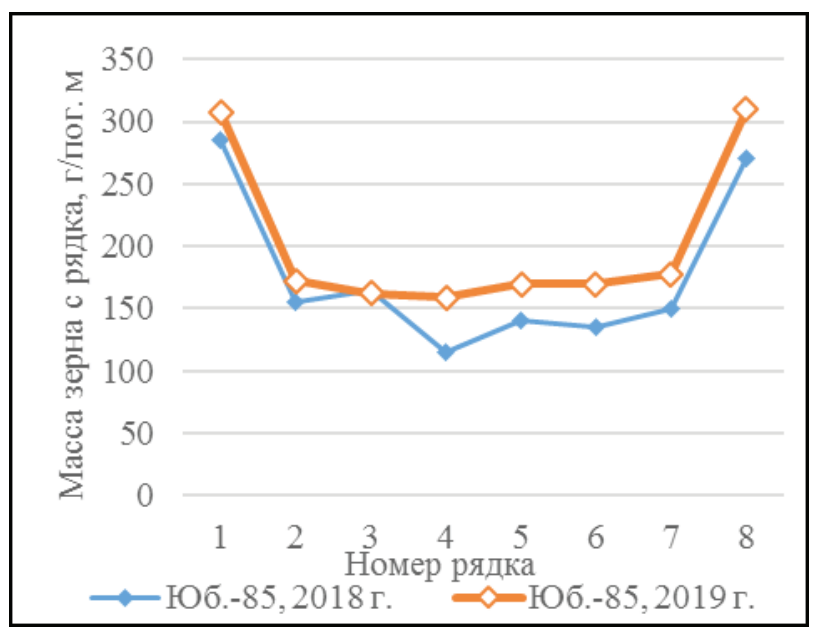

Юбилейный-85

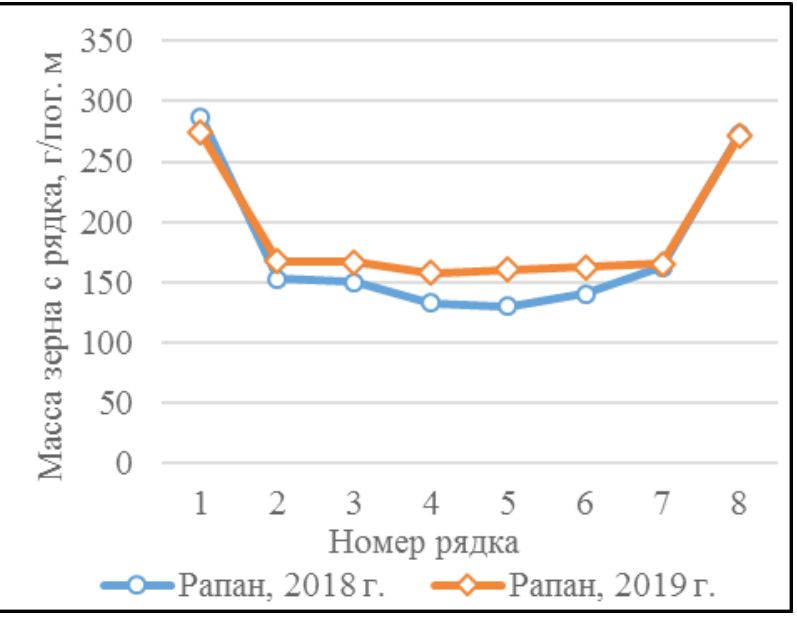

Рапан

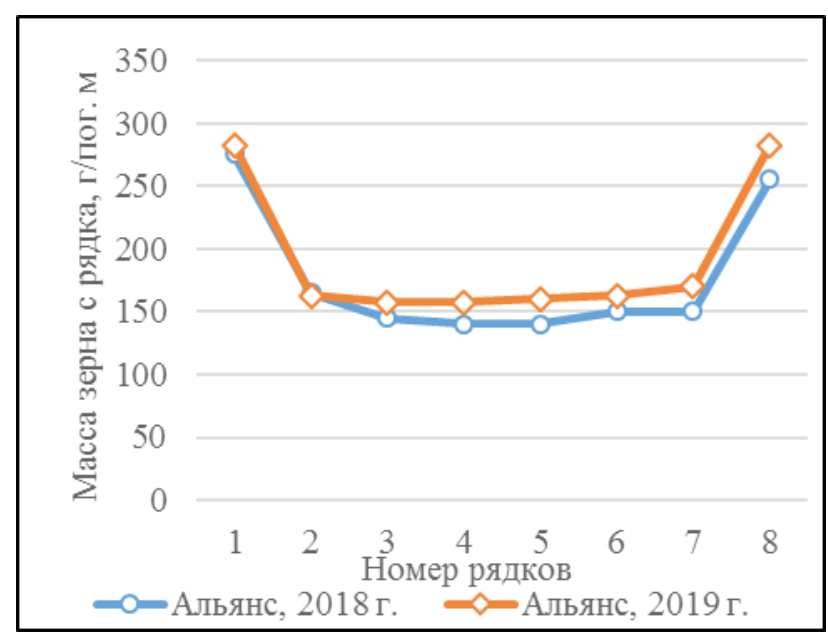

Альянс

Рисунок 1. Масса зерна с рядков в делянках сортов риса 
Кроме того, выявлены достоверные, но слабые влияния взаимодействий факторов год - номер рядка, год - сорт, номер рядка - сорт, год - номер рядка - сорт (0,8; 1,6; 1,9; 1,3 \% соответственно).

Масса зерна с одного погонного метра рядков в делянках сортов Фаворит, Рапан, Юбилейный-85 (Юб.-85), Альянс в 2018 и 2019 годах отражена на рисунках 1-4.

Крайние рядки в 2018 году в среднем сформировали 282,8 г/пог. м зерна, при варьировании от 265,0 до 308,0 г/пог. м, а остальные - 143,1 г/пог. м при варьировании в пределах 136,3 - 148,3 г/пог. м (табл. 2).

Прибавка массы зерна с крайних рядков по отношению к остальным, в среднем составила 139,7 г/пог. м или 98,1 \%. Доля прибавки массы зерна с крайних рядков в общий урожай с одного погонного метра делянки составила 19,6 \%, при этом наибольшей она была у сорта Фаворит (24,0 \%), а наименьшей у сорта Альянс 16,4 \%. У сортов Рапан и Юбилейный-85 краевой эффект составил 19,0 \%.

В 2019 году средняя масса зерна крайнего рядка немного увеличилась и составила 286,3 г/пог. м, при варьировании в пределах 272,5 - 308,8 г/пог. м. Масса зерна с рядков не подверженных краевому эффекту в среднем больше, чем в 2018 году на 17,0 г/пог. м и составила 160,1 г/пог. м. Прибавка крайнего рядка снизилась на 10,1 г/пог. м (129,6 г/пог. м против 139,7 г/пог. м в 2018 году). Наименьшей прибавкой массы зерна с крайнего рядка характеризуется сорт Рапан - 109,4 г/пог. м (67,0 \%), поэтому и доля вклада крайних рядков в общую урожайность делянки у него самая низкая 14,4 \%, при средней 16,8 \%.

Уменьшение краевого эффекта в 2019 году, вероятно, связано с лучшими условиями выращивания, в сравнении с 2018 годом.

В среднем, за два года масса зерна с крайнего рядка составила 286,3 г/пог. м, а рядков не испытывающих краевого эффекта 151,6 г/пог. М. Прибавка зерна с крайнего рядка составила 134,6 г/пог. м или 89,0%, т.е. крайние рядки формируют почти в 2 раза больше зерна, чем остальные рядки. Доля вклада прибавки массы зерна за счёт краевого эффекта в общий урожай составила $18,2 \%$.

Таблица 2. Средняя масса зерна с одного погонного метра рядка в восьмирядковой делянке разных сортов риса и доля прибавки крайних в общий урожай в 2018-2019 гг.

\begin{tabular}{|c|c|c|c|c|c|c|}
\hline \multirow{2}{*}{ Сорт } & \multirow{2}{*}{$\begin{array}{c}\text { Средняя масса } \\
\text { зерна по } \\
\text { крайним рядкам, } \\
\text { г/пог. м }\end{array}$} & \multirow{2}{*}{$\begin{array}{c}\text { Средняя } \\
\text { масса зерна } \\
\text { по остальным } \\
\text { рядкам, г/пог. м }\end{array}$} & \multicolumn{2}{|c|}{$\begin{array}{c}\text { Прибавка зерна с } \\
\text { крайних рядков }\end{array}$} & \multirow{2}{*}{$\begin{array}{c}\text { Всего зерна } \\
\text { с } 1 \text { погон- } \\
\text { ного метра } \\
\text { делянки, г }\end{array}$} & \multirow{2}{*}{$\begin{array}{c}\text { Доля прибавки } \\
\text { крайних рядков } \\
\text { в общем } \\
\text { урожае, \% }\end{array}$} \\
\hline & & & г/пог. м & $\%$ & & \\
\hline \multicolumn{7}{|c|}{2018 г. } \\
\hline Фаворит & 308,8 & 136,3 & 172,5 & 127,0 & 1435,0 & 24,0 \\
\hline Рапан & 280,0 & 144,6 & 135,4 & 94,0 & 1427,5 & 19,0 \\
\hline Юб.-85 & 277,5 & 143,3 & 134,2 & 94,0 & 1415,0 & 19,0 \\
\hline Альянс & 265,0 & 148,3 & 116,7 & 79,0 & 1420,0 & 16,4 \\
\hline Среднее & 282,8 & 143,1 & 139,7 & 98,1 & 1424,4 & 19,6 \\
\hline \multicolumn{7}{|c|}{2019 г. } \\
\hline Фаворит & 295,0 & 147,1 & 147,9 & 101,0 & 1472,5 & 20,1 \\
\hline Рапан & 272,5 & 163,1 & 109,4 & 67,0 & 1523,8 & 14,4 \\
\hline Юб.-85 & 308,8 & 168,5 & 140,2 & 83,0 & 1628,8 & 17,2 \\
\hline Альянс & 282,5 & 161,7 & 120,8 & 75,0 & 1535,0 & 15,7 \\
\hline Среднее & 289,7 & 160,1 & 129,6 & 81,0 & 1540,0 & 16,8 \\
\hline Ген. среднее & 286,3 & 151,6 & 134,6 & 89,0 & 1482,2 & 18,2 \\
\hline $\mathrm{HCP}_{05}$ & \multicolumn{2}{|c|}{27,5} & - & - & - & - \\
\hline
\end{tabular}

Результаты изучения краевого эффекта по предшественнику многолетние травы (высокий агрофон) на сортообразцах конкурсного испытания представлены в таблице 3. Масса зерна с крайнего рядка в среднем составила 265,3 г/пог. м, а с других рядков - 130,5 г/пог. м. Прибавка за счёт краевого эффекта составила
134,8 г/пог. м или 103,0 \%. Следует отметить, что образец ВНИИР 7146 был поражён пирикуляриозом, причём болезнью были поражены больше средние рядки делянки, поэтому краевой эффект у него особенно выражен (прибавка урожая зерна с крайнего рядка составила 167,5 г/пог. м или $144 \%$. 
Таблица 3. Результаты изучения краевого эффекта на сортообразцах конкурсного испытания в 2020 г. (предшественник многолетние травы)

\begin{tabular}{|c|c|c|c|c|c|c|c|c|c|}
\hline \multirow{2}{*}{$\begin{array}{c}\text { Сорт, } \\
\text { образец }\end{array}$} & \multicolumn{4}{|c|}{ Масса зерна, г/пог. м } & \multirow{2}{*}{$\begin{array}{c}\text { Средняя } \\
\text { масса } \\
\text { зерна } \\
\text { рядков без } \\
\text { крайних, } \\
\text { г/пог. м }\end{array}$} & \multirow{2}{*}{$\begin{array}{l}\text { Средняя } \\
\text { масса } \\
\text { зерна с } \\
\text { крайних } \\
\text { рядков, } \\
\text { г/пог. м }\end{array}$} & \multicolumn{2}{|c|}{$\begin{array}{c}\text { Прибавка массы } \\
\text { зерна крайних } \\
\text { рядков }\end{array}$} & \multirow{2}{*}{$\begin{array}{c}\text { Доля } \\
\text { прибавки } \\
\text { крайних } \\
\text { рядков } \\
\text { в общем } \\
\text { урожае, \% }\end{array}$} \\
\hline & $\begin{array}{c}\text { правый } \\
\text { рядок }\end{array}$ & $\begin{array}{c}\text { средние } \\
\text { рядки } \\
(2-7)\end{array}$ & $\begin{array}{l}\text { левый } \\
\text { рядок }\end{array}$ & $\begin{array}{c}\text { всего с } \\
\text { делянки }\end{array}$ & & & г/пог. м & $\%$ & \\
\hline ВНИИР 6524 & 280,0 & 918,4 & 294,4 & 1484,8 & 153,1 & 287,2 & 134,1 & 88,0 & 18,1 \\
\hline ВНИИР 7146 & 262,4 & 699,2 & 305,6 & 1259,2 & 116,5 & 284,0 & 167,5 & 144,0 & 26,6 \\
\hline ВНИИР 7099 & 220,8 & 731,2 & 228,8 & 1172,8 & 121,9 & 224,8 & 102,9 & 84,0 & 17,6 \\
\hline Среднее & 254,4 & 782,9 & 276,3 & 1305,6 & 130,5 & 265,3 & 134,8 & 103,0 & 20,7 \\
\hline
\end{tabular}

Доля прибавки массы зерна крайних рядков в общий урожай с делянки, по трём сортам, составила в среднем 20,7 \%. Наибольшими значениями показателя характеризуется сортообразец ВНИИР 7146 (26,6%). У двух других сортообразцов доля вклада краевого эффекта составила 17,6 $18,1 \%$.
Пересчёт урожайности сортообразцов риса конкурсного сортоиспытания на один гектар посева, показал, что в делянках с краевым эффектом в среднем сформировалось 108,7 ц/га зерна риса, при этом учётная площадь делянки была рассчитана исходя из длины 12,5 м и ширины восьмирядковой делянки 1,20 м (8 x 0,15 м) (табл. 4).

Таблица 4. Урожайность сортообразцов конкурсного испытания с краевым эффектом и без его влияния, 2020 г. (предшественник многолетние травы)

\begin{tabular}{|c|c|c|c|c|c|}
\hline \multirow[t]{2}{*}{ Сорт, образец } & \multirow{2}{*}{$\begin{array}{c}\text { Урожайность } \\
\text { с краевым } \\
\text { эффектом, ц/га } \\
\left(\mathrm{S}=15,0 \mathrm{~m}^{2}\right)\end{array}$} & \multirow{2}{*}{$\begin{array}{c}\text { Урожайность } \\
\text { без краевого } \\
\text { эффекта, } \\
\text { ц/га } \\
\left(\mathbf{S}=11,25 \text { м²) }^{2}\right.\end{array}$} & \multicolumn{2}{|c|}{$\begin{array}{c}\text { Прибавка урожайности от } \\
\text { краевого эффекта }\end{array}$} & \multirow{2}{*}{$\begin{array}{c}\text { Попра- } \\
\text { вочный } \\
\text { коэффи- } \\
\text { циент }\end{array}$} \\
\hline & & & ц/га & $\%$ & \\
\hline ВНИИР 6524 & 123,7 & 101,1 & $+22,6$ & 18,2 & 0,817 \\
\hline ВНИИР 7146 & 104,9 & 76,8 & $+28,1$ & 26,7 & 0,732 \\
\hline ВНИИР 7099 & 97,7 & 80,4 & $+17,3$ & 17,7 & 0,822 \\
\hline Среднее & 108,7 & 86,1 & $+22,6$ & 20,8 & 0,792 \\
\hline $\mathrm{HCP}_{05}$ & \multicolumn{2}{|c|}{12,6} & - & - & - \\
\hline
\end{tabular}

Исключив из расчёта 2 крайних рядка при той же длине делянки и ширине 0,9 м (6 х 0,15 м), получили урожайность 86,1 ц/га, что на 22,6 ц/га или 20,8 \% меньше.

На основе полученных результатов рассчитаны поправочные коэффициенты для пересчёта урожайности сортов риса с делянок на 1 га посева, которые различаются в зависимости от генотипа. В среднем значение поправочного коэффициента составляет 0,792 при варьировании в пределах 0,732 - 0,822.

Таким образом, для получения объективных данных урожайных свойств сортов риса в восьмирядковых делянках, необходимо в обязательном порядке исключать влияние краевого эффекта. Это возможно достичь двумя способами. Одним из таких способов является использование поправочного коэффициента. В связи с различиями в проявлении краевого эффекта у генотипов, достаточно сложной задачей является определение индивидуальных поправочных коэффициентов, но так как в опытах изучались разнотипные сорта и сортообразцы риса, возможно использование усреднённого поправочного коэффициента $(0,8)$. Так как, разные типы сортов (экстенсивные, полуинтенсивные, интенсивные) в конкурсном сортоиспытании сравниваются со своими стандартами, то применение общего поправочного коэффициента сохранит искажение различий в урожайности между группами сортов.

Другой способ устранения искажений урожайности делянок - применение в расчётах увеличенной ширины делянки. Так как крайние рядки формируют повышенную почти в два раза массу зерна (89,0 - 103,0 \%), то к восьмирядковой делянке можно прибавить 2 виртуальных междурядья ((8+2) х 0,15 м = 1,5 м), получив при этом ширину делянки в 1,5 м. Такой подход также позволит частично учесть и краевой эффект на торцах делянки.

\section{Выводы}

Краевой эффект существенно влияет на урожайность риса в восьмирядковых делянках. Доля его 
вклада в общий урожай зерна с делянки в среднем составляет 18,2 - 20,7 \%, а прибавка массы зерна с крайних рядков по отношению к среднестатистическому рядку в делянке 89 - 103 \%, т.е. 2 крайних рядка в восьмирядковой делянке формируют массу зерна равную 4 рядкам не подверженным краевому эффекту.
Для приближения урожайности сортов риса в делянках, при пересчёте на гектар, к значениям урожайности в условиях производства, следует использовать усреднённый поправочный коэффициент 0,8, либо при расчёте площади 8-рядковой делянки, её ширину увеличивать на 2 междурядья, т.е. $(8+2) \times 0,15=1,5$ м вместо $8 \times 0,15 \mathrm{~m}=1,20 \mathrm{~m}$.

\section{ЛИТЕРАТУРА}

1. Деревецкий, Н.Ф. Опытное дело в растениеводстве. - Кишинёв: Штиинца, 1962. - 258 с.

2. Доспехов, Б. А. Методика полевого опыта / Б. А. Доспехов. - Москва: Колос, 1979. - 416 с.

3. Игонин, В.Н. Точность и достоверность оценок в селекционном питомнике яровой пшеницы. Дис. кан. с.-х. наук. - М,1994. - 132с.

4. Ковалёв, В. С. Совершенствование методики и техники закладки конкурсного сортоиспытания риса / В. С. Ковалев, Н. В. Остапенко //Тезисы докладов конференции молодых учёных и специалистов. - Краснодар, 1987. C. $10-12$

5. Коновалов, Ю.Б. Оценка различных признаков яровой пшеницы в селекционном питомнике/ Ю.Б. Коновалов, В.А. Климачёва // Изв. ТСХА. - 1975. - №6. - С.47-57.

6. Коновалов, Ю.Б. Влияние дорожки в модельном питомнике отбора на элементы структуры урожая растений яровой пшеницы / Ю.Б. Коновалов, В.А. Лошакова // Актуальные вопросы селекции и семеноводства полевых культур: Сб. науч. трудов. - М.,1978. - С.112-118.

7. Коновалов, Ю.Б. Оценки линий яровой пшеницы в селекционных питомниках различных типов / Ю.Б. Коновалов, О.К. Назаренко // Изв. ТСХА. - 1968. - №5 - С.91-104.

8. Коновалов, Ю.Б. О проблемах полевого опыта в селекции сельскохозяйственных культур // Селекция и семеноводство. - 1991. - № 2. - С. 2-6.

9. Кучугурная, Т.С. Эффект краевых рядков и точность полевого опыта // Селекция и семеноводство. - 1981. - № 5. - 29 c.

10. Молчан, И.М. Биоценогенетические принципы создания пластичного сорта пшеницы в процессах селекции и семеноводства // С.-х. биология. - 1987. - № 2. - С. 87-96.

11. Нужный, А.Ф. К методике оценки урожайности селекционного материала // Селекция и семеноводство. 1983. - № 5. - 22 c.

12. Оглы, А.М. Влияние краевого эффекта на результаты сортоиспытаний. В сб.: «Научные приоритеты адаптивной интенсификации сельскохозяйственного производства», 3-5 июля 2019 г., Краснодар: материалы. Краснодар: ФГБНУ «ВНИИ риса», 2019. - С. 57 - 59.

13. Синякова, Л.А. Изменение структуры растения в онтогенезе в связи с условиями выращивания // Науч. техн. бюл. ВСГИ. - 1972. - Вып. 20. - С.60-63.

14. Сметанин, А. П. Методики опытных работ по селекции, семеноводству, семеноведению и контролю за качеством семян риса / А. П. Сметанин, В. А. Дзюба, А. И. Апрод. - Краснодар: Кн. Изд-во, 1972. - 156 с.

15. Romani M., Borghi B., Alberici R., Delogu G., Hesselbach J., Salamini F. Intergenotypic competition and border effect in bread wheat and barley // Euphytica. 1993. - V. 69. - № 1/2. - P. 19-31.

\section{REFERENCES}

1. Derevetsky, N.F. Experimental work in plant growing. - Chisinau: Shtiintsa, 1962.- $258 \mathrm{p}$

2. Dospekhov, B.A. Method of field experiment / B.A. Dospekhov. - Moscow: Kolos, 1979. - 416 p.

3. Igonin, V.N. Accuracy and reliability of estimates in the spring wheat breeding nursery. Ph.D. thesis. - M, 1994. - 132 p.

4. Kovalev, V. S. Improvement of the methodology and technique of laying the competitive rice variety testing / V. S. Kovalev, N. V. Ostapenko // Abstracts of the conference of young scientists and specialists. - Krasnodar, 1987. - P. 10 -12.

5. Konovalov, Yu.B. Assessment of various traits of spring wheat in a breeding nursery / Yu.B. Konovalov, V.A. Klimachev // "Izvestiya of Timiryazev Agricultural Academy (TAA)". - 1975. - № 6. - P. 47 - 57.

6. Konovalov, Yu.B. Influence of the row in the model breeding nursery on the structure elements of spring wheat plants / Yu.B. Konovalov, V.A. Loshakova // Topical issues of breeding and seed production of field crops: Collection scientific. works. - M., 1978. - P. $112-118$.

7. Konovalov, Yu.B. Assessment of spring wheat lines in breeding nurseries of various types / Yu.B. Konovalov, O. K. Nazarenko // "Izvestiya of Timiryazev Agricultural Academy (TAA)". - 1968. - № 5 - P. 91 - 104.

8. Konovalov, Yu.B. On the problems of field experiement in breeding of agricultural crops // Breeding and seed production. - 1991. - № 2. - P. 2 - 6.

9. Kuchugurnaya, T.S. The effect of the edging rows and the accuracy of the field experiment // Selection and seed production. - 1981. - №. 5. - 29 p.

10. Molchan, I.M. Biocenogenetic principles of developing a plastic wheat variety in the processes of breeding and seed production // Agricultural biology. - 1987. - № 2. - P. 87 - 96.

11. Nuzhny, A.F. To the method of assessing the yield of breeding material // Breeding and seed production. - 1983. № 5 . $-22 p$. 
12. Ogly, A.M. Influence of the edge effect on the results of variety testings. Collection of materials: "Scientific priorities of adaptive intensification of agricultural production", 3-5 July 2019, Krasnodar, FSBSI "ARRRI”. - 2019. - P. 57 - 59.

13. Sinyakova, L.A. Changes in the plant structure in ontogenesis in connection with growing conditions // Scientific and technical bulletin of All-Union Breeding and Genetic Institute - 1972. - Issue 20. - P. 60 - 63.

14. Smetanin, A. P. Methods of experimental work on breeding, seed production, seed science and quality control of rice seeds / A. P. Smetanin, V. A. Dzyuba, A. I. Aprod. - Krasnodar: Publishing house, 1972. - 156 p.

15. Romani M., Borghi B., Alberici R., Delogu G., Hesselbach J., Salamini F. Intergenotypic competition and border effect in bread wheat and barley // Euphytica. - 1993. - V. 69. - № 1/2. - P. 19 - 31.

\section{Оглы Андрей Михайлович}

Заведующий отделом селекции

E-mail: ogly-a@mail.ru

\section{Ковалёв Виктор Савельевич}

Заместитель директора по научной работе

E-mail: arri_kub@mail.ru

Bce: ФГБНУ «ФНЦ риса»

350921, Россия, Краснодар, Белозерный, 3

\section{Максименко Евгений Петрович}

Директор ФГБУ ЭСОС «Красная» филиал ФГБНУ «ФНЦ риса»

353826, Россия, п. Рисоопытный, Комсомольская, 21

\section{Ogly Andrey Mikhailovich}

Head of breeding department

E-mail: ogly-a@mail.ru

\section{Kovalev Viktor Savelievich}

Deputy director on scientific work

E-mail: arrri_kub@mail.ru

All: FSBSI "Federal Scientific Rice Centre"

3, Belozerny, Krasnodar, 350921, Russia

\section{Maksimenko Evgeny Petrovich}

Director of FSBI ESOS "Krasnoe"

branch of FSBSI "Federal Scientific Rice Centre"

21, Komsomolskaya, Risopytniy, 353826, Russia 


\section{РЕАКЦИЯ СОРТОВ РИСА НА РАЗЛИЧНУЮ ОБЕСПЕЧЕННОСТЬ ВЛАГОЙ В ПЕРИОД ПРОРАСТАНИЯ}

Рисоводческая отрасль является основным потребителем оросительной воды в Краснодарском крае. В засушливые годы, каковым был 2020 г., возникает дефицит воды для обеспечения риса необходимым объемом в течение всей вегетации. Один из путей снижения расхода воды при выращивании риса - это создание и использование сортов, устойчивых к недостатку влаги в период вегетативного роста растений. В статье представлены результаты лабораторного опыта по изучению реакции разнотипных сортов риса на различную обеспеченность влагой в период прорастания. Для исследования использованы сорта: крупнозерный Титан (подвид japonica) и длиннозерные (подвид indica) - белозерная Злата и краснозерный Марс. Установлено, что изученные сорта по-разному реагируют на обеспеченность влагой при прорастании. Сорт Злата показал лучшие результаты, в сравнении с сортами Марс и Титан, по энергии прорастания, всхожести и длине корешков у проростков при достаточно полном обеспечении влагой. Сорт Титан оказался лучшим по изучаемым параметрам при дефиците влаги. У Титана с 3-го дня после начала прорастания семян на корешках образовались корневые волоски, которые, очевидно, помогали всасывать влагу. Поэтому в варианте с недостаточным увлажнением у Титана оказались лучшие показатели по энергии прорастания, всхожести и длине корешков, чем у длиннозерных сортов риса.

Ключевые слова: рис, сорт, корневые волоски, энергия прорастания, всхожесть, дефицит влаги при прорастании, устойчивость к засухе.

\section{Введение}

Рис (Oryza sativa L.) является одним из наиболее распространенных культурных злаков в мировой сельскохозяйственной практике. В большинстве стран, включая Россию, рис принято возделывать при слое воды. Технология возделывания риса при слое воды оказала влияние на морфологическое и анатомическое строение растения в связи с недостаточным содержанием кислорода в затопленных почвах. По отношению к влажности рис относится к экологической группе светолюбивых гигрофитов, корни и стебли которых снабжены аэренхимой - воздухоносной тканью с увеличенными межклетниками и полостями. Механическая ткань, эпидерма и кутикула у таких растений развиты слабо, корни обычно маловетвящиеся [13]. В условиях затопления корни риса, находящиеся в поверхностном слое почвы, не имеют корневых волосков как у суходольных культур и развиваются по типу водных растений [2].

В период прорастания зерновок риса образуется главный зародышевый корешок, а после появления зеленого листа формируются придаточные корни первичной корневой системы. Во время кущения

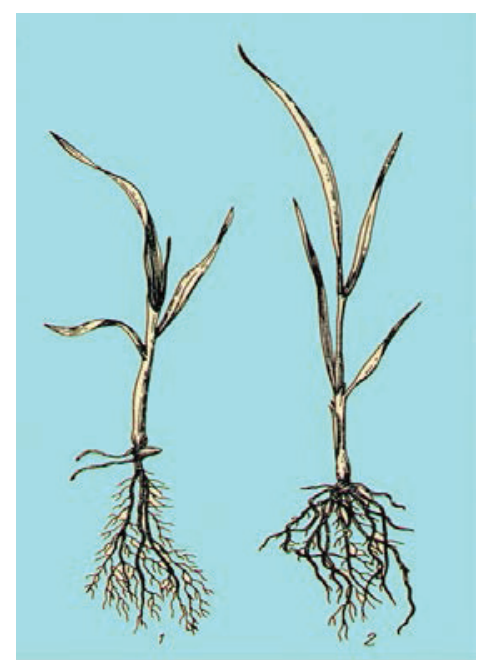

a

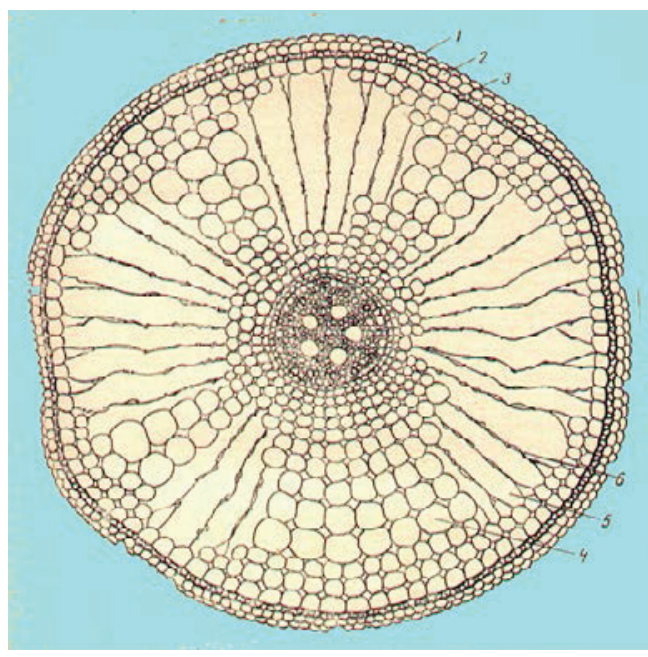

б

Рисунок 1. Развитие корневой системы риса в разных условиях (а); аэренхима корня риса (б) [4] 
возникают вторичные корни, которые образуют мочковатую корневую систему. Если растения риса растут при увлажнении без слоя воды, то их корни покрыты, как у суходольных злаков, корневыми волосками (рис. 1 а). Корни риса, растущего при слое воды, не имеют волосков и формируют воздухоносную ткань - аэренхиму (рис. 1 б), которая является проводником кислорода из надземных органов в почву. Это позволяет растению риса нормально развиваться при затоплении [4].

Корни, выполняя свою непосредственную функцию, участвуют в поступлении питательных веществ и воды, синтезе гормонов растений, органических кислот и аминокислот и закреплении растений в почве. Морфология и физиология корней тесно связаны с ростом и развитием надземной части растения $[9,17]$.

Проведенная сравнительная оценка анатомии корней риса, пшеницы и типичного водного растения - водного гиацинта (Eichhornia crassipes (Mart.) Solms) показала, что в начале вегетационного периода по своему строению корни риса не формируются по типу водных растений, а, наоборот, стоят ближе к типу корней обычных суходольных растений. Только после продолжительного затопления поля слоем воды, корни риса начинают приобретать черты, приближающие их по анатомическому строению и морфологии к корням типично водных растений - гидрофитов [1].

По мере увеличения населения мира спрос на зерновые культуры, включая рис, значительно возрастает. Это требует дополнительных запасов пресной воды для орошения рисовых полей. Из-за дефицита этих запасов в ряде стран проводятся разносторонние исследования по изучению генетических ресурсов риса в связи с физиологической и морфобиологической реакцией растений на недостаток влаги во время вегетации $[10,11]$.

В целях снижения расхода воды для выращивания риса в ряде стран Азии испытывается метод управления водными ресурсами - безопасное чередование увлажнения и подсушивания почвы (AWD). $\mathrm{K}$ настоящему времени влияние AWD на рост растений, урожайность и качество зерна риса изучено недостаточно [15]. Стресс из-за засухи является основным препятствием для выращивания риса по системе AWD. Засуха негативно влияет на уровень урожайности риса и его стабильность во многих богарных регионах Азии, Африки и Южной Америки [14]. И все же использование сортов риса, выдерживающих попеременное увлажнение и подсушивание почвы на вегетативной стадии роста растений, позволяет получать урожай не ниже, чем по технологии с использованием непрерывного затопления рисовых полей [16]. В число сортов, выносливых к условиям засухи, входит IR-64, созданный в Международном институте риса [12]. Исследования по подбору сортов риса, способных расти при дефици- те воды, ведутся и в Российской Федерации [7]. Засуха на юге европейской части России летом 2020 г. усилила актуальность таких исследований.

\section{Цель исследований}

Изучить реакцию сортов риса на разную обеспеченность влагой в период прорастания в условиях лабораторного опыта.

\section{Материалы и методы}

Материалом для исследования послужили семена трех разнотипных среднеспелых сортов риса российской селекции: крупнозерный Титан (подвид japonica) и длиннозерные (подвид indica) - Злата, с белым зерном и Марс, с красным перикарпом зерна $[4,5,6]$.

Опыты закладывали в соответствии с методикой, принятой для риса [8]. Семена сортов риса помещали в растильни по 100 штук в каждую на 2 слоя фильтровальной бумаги. Сверху семена накрывали слоем такой же бумаги и заливали водой согласно схемы опыта (табл. 1). Повторность в опыте трехкратная.

Таблица 1. Схема лабораторного опыта

\begin{tabular}{|c|c|c|c|}
\hline \multirow{2}{*}{ Вариант } & \multicolumn{2}{|c|}{ Сорт } \\
\cline { 2 - 3 } & Злата & Марс & Титан \\
\hline 1 - & Вода: 200 мл +100 мл на 3-е сутки \\
\hline 2 & Вода: 200 мл \\
\hline 3 & Вода: 100 мл \\
\hline
\end{tabular}

Перед установкой в термостат, в растильни контрольного и второго варианта опыта было залито по 200 мл воды, а в третьем варианте - 100 мл. Контроль за количеством воды в растильнях проводился ежедневно. На 3-е сутки количество воды в контрольном и втором варианте было в пределах 130-150 мл, а в третьем варианте около 50 мл. В растильню контрольного варианта было дополнительно долито 100 мл воды. На момент завершения опыта на 7-е сутки в растильне контрольного варианта фильтровальная бумага была частично залита водой, а во втором варианте обильно смочена. В третьем варианте фильтровальная бумага была слегка влажной.

На 4-е сутки опыта определяли энергию прорастания - количество нормально проросших семян в лабораторном термостате при температуре $28^{\circ} \mathrm{C}$. Лабораторную всхожесть определяли на 7-е сутки, а также измеряли длину зародышевого корешка. Данные обрабатывали методами биометрической статистики [3].

\section{Результаты и обсуждение}

В ходе выполнения лабораторного опыта было отмечено различие по изучаемым параметрам как между вариантами в зависимости от обеспеченности влагой, так и между сортами Злата, Марс и Титан (табл. 2). 
Таблица 2. Энергия прорастания, всхожесть семян и длина корешков сортов риса в зависимости от различной обеспеченности влагой, 2020 г.

\begin{tabular}{|c|c|c|c|c|}
\hline \multirow{2}{*}{ Вариант } & Сорт & $\begin{array}{c}\text { Энергия } \\
\text { прорастания, \% }\end{array}$ & Всхожесть, \% & $\begin{array}{c}\text { Длина } \\
\text { корешка, см }\end{array}$ \\
\hline \multirow{3}{*}{1 - контроль } & Злата & 89 & 97 & 8 \\
\cline { 2 - 5 } & Марс & 87 & 95 & 6 \\
\cline { 2 - 5 } & Титан & 85 & 94 & 7 \\
\hline \multirow{3}{*}{2} & Злата & 83 & 93 & 5 \\
\cline { 2 - 5 } & Марс & 80 & 92 & 6 \\
\cline { 2 - 5 } & Титан & 83 & 83 & 6 \\
\cline { 2 - 6 } & Злата & 75 & 85 & 5 \\
\hline \multirow{2}{*}{3} & Марс & 71 & 87 & 7 \\
\hline
\end{tabular}

Рассматривая данные таблицы 2 по вариантам, видим, что наилучшие показатели по энергии прорастания, всхожести и длине корешков все три сорта показали в первом (контрольном) варианте, при избытке влаги в растильнях. Во втором и третьем вариантах, с уменьшением количества воды в растильнях, все три изучаемых показателя у каждого сорта достоверно снижаются.

При анализе данных по сортам выявляется, что в контрольном и втором вариантах, с 200 мл воды, сорт Злата достоверно превосходит сорта Марс и Титан по показателям энергии прорастания и всхожести. Самые низкие результаты по обоим показателям у сорта Титан. Сорт риса Марс имеет промежуточные результаты. Но в третьем варианте опыта, при наименьшей влагообеспеченности, сорт Титан по энергии прорастания и по всхожести достоверно превзошел оба длиннозерных сорта.

Измерение длины корешков на 7-е сутки опыта выявило, что лучшие показатели были у сорта Злата в первом и втором варианте. Сорт Титан в этих вариантах был вторым, а Марс-третьим. А вот в третьем варианте, при дефиците влаги, длина корешка была наибольшей у сорта Титан. Злата оказалась второй, а Марс - третьим.

При осмотре корешков изучаемых сортов был зафиксирован интересный факт в третьем ва-

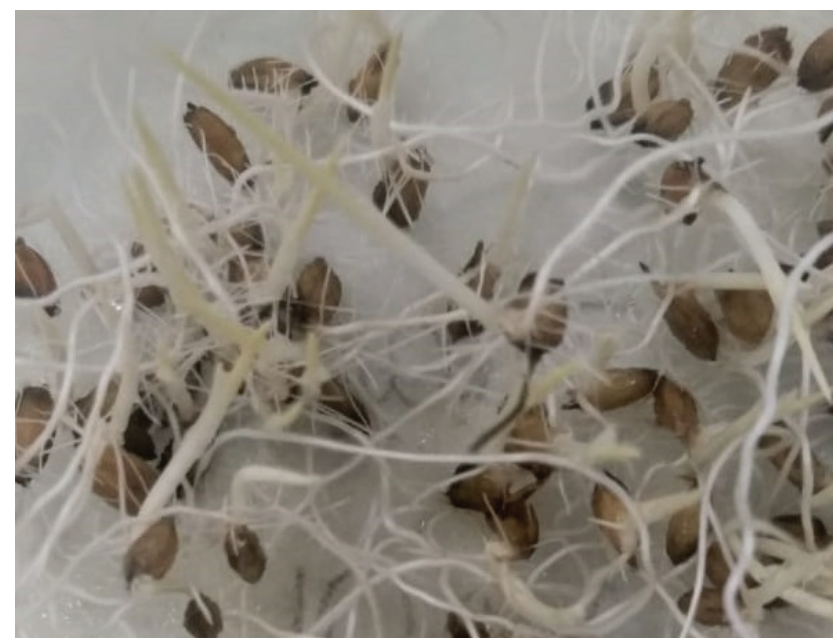

Рисунок 2. Проростки сорта риса Титан рианте. Уже на 3-е сутки у сорта риса Титан при недостаточном увлажнении активно развивались корневые волоски по всей длине корня. Это стало особенно хорошо видно на 7-е сутки. Корневые волоски располагались по всему корешку равноудаленно друг от друга на расстоянии 1-2 мм и имели длину 3-5 мм (рис. 2). Это была явно выраженная реакция сорта на нехватку влаги. Из этого следует, что сорт Титан в данных условиях начал развивать корневую систему по суходольному типу.

Появление корневых волосков у сорта риса Титан при недостатке влаги позволило ему более эффективно потреблять воду. Это привело к улучшению показателей энергии прорастания, всхожести и длины корешков по сравнению с сортами Злата и Марс.

На корешках проростков сортов риса Злата и Марс корневые волоски не появлялись. Такой реакции на недостаток влаги, как у сорта Титан, у них не наблюдалось (рис. 3, 4). Корешки проростков длиннозерных сортов во всех трех вариантах были идентичными.

Из этого наблюдения можно высказать предположение, что у изученных длиннозерных сортов риса менее развит механизм реагирования на недостаточное увлажнение. Для подтверждения этого предположения целесообразно провести изучение широкого набора сортов риса обоих подвидов.

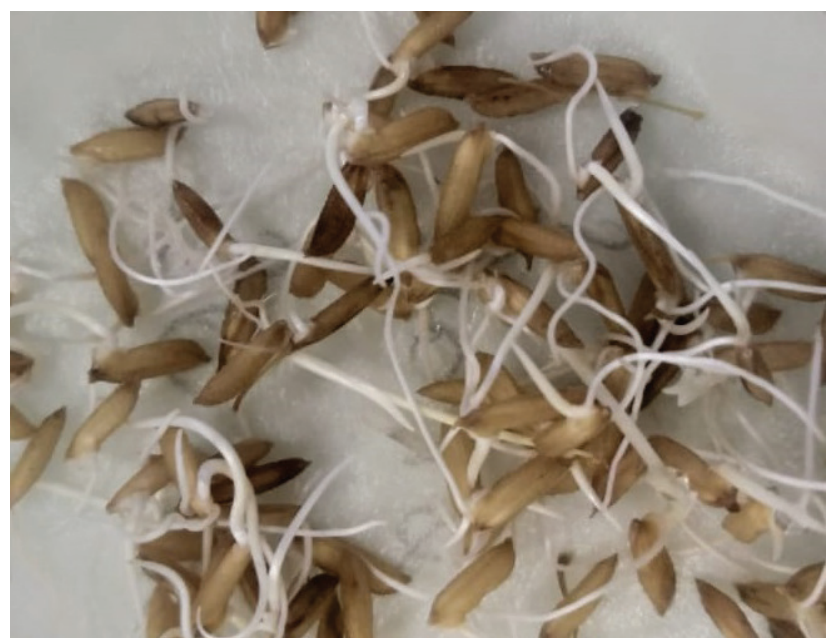

Рисунок 3. Проростки сорта риса Злата 


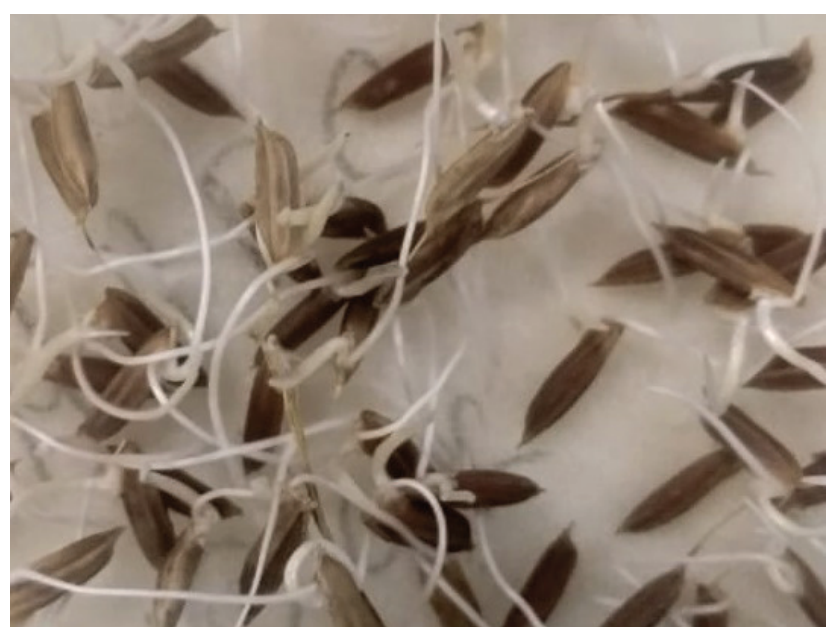

Рисунок 4. Проростки сорта риса Марс

\section{Выводы}

1. Изученные разнотипные сорта риса Злата, Марс и Титан по-разному реагируют на обеспеченность влагой в период прорастания.

2. При достаточном обеспечении влагой при прорастании семян риса лучшие показатели энергии прорастания, всхожести и длины корешков получены у длиннозерного белозерного сорта Злата.

3. У крупнозерного сорта риса Титан при недостатке влаги уже на 3-й день после начала прорастания семян на корнях появились корневые волоски, которые, очевидно, позволили ему в этих условиях превзойти сорта Злата и Марс по показателям энергии прорастания, всхожести и длины корешка.

\section{ЛИТЕРАТУРА}

1. Алешин, Е. П. Рис / Е. П. Алешин, Н. Е. Алешин. - М.: Заводская правда, 1993. - 504 с.

2. Ганиев, М. А. Особенности морфологии и анатомии риса при периодических поливах / М. А. Ганиев, И. П. Кружилин, К. А. Родин // Орошаемое земледелие. - 2014. - №. 2. - С. 15-16.

3.Дзюба, В. А. Многофакторные опыты и методы биометрического анализа экспериментальных данных / В. А. Дзюба // Методические рекомендации. Краснодар, 2007. - 76 с.

4. Зеленский, Г. Л. Рис: биологические основы селекции и агротехники: монография / Г. Л. Зеленский. - Краснодар: КубГАУ, 2016. - 238 с.

5. Зеленский, Г. Л. К проблеме создания и внедрения высококачественных длиннозерных сортов риса / Г. Л. Зеленский, Н. Г. Туманьян, О. В. Зеленская, Н. В. Остапенко, А. А. Кочубей // АгроСнабФорум. - 2015. - № 11 (139). - C. 62-66.

6. Зеленская, О. В. Генетические ресурсы риса (Oryza sativa L.) с окрашенным перикарпом зерна / О. В. Зеленская, Г. Л. Зеленский, Н. В. Остапенко, Н. Г. Туманьян // Вавиловский журнал генетики и селекции. - 2018. - № 3(22). - С. $296-303$.

7. Костылев, П. И. Сравнительная оценка урожайности суходольных образцов риса при разных режимах орошения / П. И. Костылев, А. В. Аксенов, Е. В. Краснова, Е. В. Дубина // Рисоводство. - 2020. - № 4 (49). - С. $22-27$.

8. Сметанин, А. П. Методики опытных работ по селекции, семеноводству, семеноведению и контролю за качеством семян риса / А. П. Сметанин, В. А. Дзюба, А. И. Апрод. - Краснодар, 1972. - 156 с.

9. Counce, P. A. Rice physiology / P. A. Counce, D. R. Gealy, S. J. S. Sung // In: Smith, C. W., comps., eds. Rice. New York, 2002. - NY: John Wiley and Sons Ltd. - P. 129-152.

10. Gowda, V. R. P. Root biology and genetic improvement for drought avoidance in rice / V. R. P. Gowda, A. Henry, A. Yamauchi, H. E. Shashidhar, R. Serraj // Field Crops Research. - 2011. - V. 122. - Is.1. - P. 1-13. DOI:10.1016/j. fcr.2011.03.001.

11. Henry, A. Root attributes affecting water uptake of rice (Oryza sativa) under drought /A. Henry, A. J. Cal, T. C. Batoto, R. O. Torres, R. Serraj // Journal of Experimental Botany. - 2012. - V. 63. - Is. 13. - P. 4751-4763. DOI: 10.1093/jxb/ers150

12. Kato, Y. Physiological characterization of introgression lines derived from an indica rice cultivar, IR64, adapted to drought and water-saving irrigation / Y. Kato, A. Henry, D. Fujita, K. Katsura, N. Kobayashi, R. Serraj // Field Crops Research. - 2011. - V. 123. - Is. 2. - P. 130-138.

13. Mostajeran, A. Drought stress effects on root anatomical characteristics of rice cultivars (Oryza sativa L.) / A. Mostajeran, V. Rahimi-Eichi // Pakistan Journal of Biological Sciences. - 2008. - V. 11. - P. 2173-2183.

14. Nguyen, H. T. Breeding for drought resistance in rice: physiology and molecular genetics considerations / H. T. Nguyen, R. C. Babu, A. Blum // Crop Science. - 1997. - V. 37. - №. 5. - P. 1426-1434.

15. Norton, G. J. Impact of alternate wetting and drying on rice physiology, grain production, and grain quality / G. J. Norton, M. Shafaei, A. J. Travis, C. M. Deacon, J. Danku, D. Pond, A. H. Price // Field Crops Research. - 2017. - V. 205. - P. 1-13.

16. Thakur, A. K. Effects on rice plant morphology and physiology of water and associated management practices of the system of rice intensification and their implications for crop performance / A. K. Thakur, S. Rath, D. U. Patil, A. Kumar // Paddy and water Environment. - 2011. - V. 9. - № 1. - P. 13-24.

17. Yang, J. Relationships of rice root morphology and physiology with the formation of grain yield and quality and the nutrient absorption and utilization / J. Yang // Scientia Agricultura Sinica. - 2011. - T. 44. - №. 1. - C. 36-46.

\section{REFERENCES}

1. Aleshin, E. P. Rice / E. P. Aleshin, N. E. Aleshin. - M .: Zavodskaya Pravda, 1993 .- 504 p.

2. Ganiev, M. A. Features of rice morphology and anatomy during periodic watering / M. A. Ganiev, I. P. Kruzhilin, K. A. Rodin // Irrigated agriculture. - 2014. - № 2. - P. 15-16.

3. Dzyuba V.A.Multi-factor experiments and methods of biometric analysis of experimental data / V.A. Dzyuba. - Kras- 
nodar, 2007 . - 76 p.

4. Zelensky, G. L. Rice: biological foundations of breeding and agricultural technology: monograph / G. L. Zelensky. Krasnodar: KubSAU, 2016 . - 238 p.

5. Zelenskij, G.L. To the issue of development and introduction of high-quality long-grain rice varieties / G.L. Zelenskij, N.G. Tumanyan, O.V. Zelenskaya, N.V. Ostapenko, A.A. Kochu-bej // AgroSnabForum. - 2015. - № 11 (139). - P. $62-66$.

6. Zelenskaya, O. V. Genetic resources of rice (Oryza sativa L.) with stained grain pericarp / O. V. Zelenskaya, G. L. Zelensky, N. V. Ostapenko, N. G. Tumanyan // Vavilovskiy journal of genetics and breeding. - 2018. - V. 22. - № 3. - P. $296-303$.

7. Kostylev, P.I. Comparative assessment of the productivity of upland rice samples under different irrigation regimes /

P.I.Kostylev, A.V. Aksenov, E.V. Krasnova, E.V. Dubina // Rice growing. - 2020. - № 4 (49). - P. 22-27.

8. Smetanin, A. P. Methods of experimental work on breeding, seed production, seed science and quality control of rice seeds / A. P. Smetanin, V. A. Dzyuba, A. I. Aprod. - Krasnodar: Publishing house, 1972 . - 156 p.

9. Counce, P.A. Rice physiology / P. A. Counce, D. R. Gealy, S. J. S. Sung // In: Smith, CW, comps., eds. Rice. New York, 2002.NY: John Wiley and Sons Ltd. - P. 129-152.

10. Gowda, V.R.P. Root biology and genetic improvement for drought avoidance in rice / V.R.P. Gowda, A. Henry, A. Yamauchi, H.E. Shashidhar, R. Serraj // Field Crops Research. - 2011. - V. 122. - Is.1. - P. 1-13. DOI:10.1016/j.fcr.2011.03.001.

11. Henry, A. Root attributes affecting water uptake of rice (Oryza sativa) under drought /A. Henry, A.J. Cal, T.C. Batoto, R.O. Torres, R. Serraj // Journal of Experimental Botany. - 2012. - V. 63. - Is. 13. - P. 4751-4763. DOI: 10.1093/jxb/ers150

12. Kato, Y. Physiological characterization of introgression lines derived from an indica rice cultivar, IR64, adapted to drought and water-saving irrigation / Y. Kato, A. Henry, D. Fujita, K. Katsura, N. Kobayashi, R. Serraj // Field Crops Research. - 2011. - V. 123. - Is. 2. - P. 130-138.

13. Mostajeran, A. Drought stress effects on root anatomical characteristics of rice cultivars (Oryza sativa L.) / A. Mostajeran, V. Rahimi-Eichi // Pakistan Journal of Biological Sciences. - 2008. - V. 11. - P. 2173-2183.

14. Nguyen, H.T. Breeding for drought resistance in rice: physiology and molecular genetics considerations / H. T. Nguyen, R. C. Babu, A. Blum // Crop Science. - 1997. - V. 37. - №. 5. - P. 1426-1434.

15. Norton, G.J. Impact of alternate wetting and drying on rice physiology, grain production, and grain quality / G. J. Norton, M. Shafaei, A. J. Travis, C. M. Deacon, J. Danku, D. Pond, A. H. Price // Field Crops Research. - 2017. - V. 205. - P. 1-13.

16. Thakur, A.K. Effects on rice plant morphology and physiology of water and associated management practices of the system of rice intensification and their implications for crop performance / A. K. Thakur, S. Rath, D. U. Patil, A. Kumar // Paddy and water Environment. - 2011. - V. 9. - №. 1. - P. 13-24.

17. Yang, J. Relationships of rice root morphology and physiology with the formation of grain yield and quality and the nutrient absorption and utilization / J. Yang // Scientia Agricultura Sinica. - 2011. - T. 44. - №. 1. - P. 36-46.

\section{Гненный Евгений Юрьевич}

Младший научный сотрудник отдела селекции E-mail:g.gheka@gmail.com

\section{Зеленский Григорий Леонидович}

Главный научный сотрудник отдела селекции E-mail: zelensky08@mail.ru

Bce: ФГБНУ «ФНЦ риса»

350921, Россия, г. Краснодар, Белозерный, 3

\section{Ткаченко Максим Андреевич \\ Младший научный сотрудник \\ отдела агротехнологий}

ФГБНУ «НЦЗ им. П.П. Лукьяненко», 350012 г. Краснодар-12, КНИИСХ Ц/У

\section{Gnennyy Evgeny Yurievich}

Younger Researcher of the Breeding Department

E-mail:g.gheka@gmail.com

Zelensky Grigory Leonidovich.

Chief Researcher of the Breeding Department

E-mail: zelensky08@mail.ru

All: FSBSI "FNC of rice"

3, Belozerny, Krasnodar, 350921, Russia

Tkachenko Maxim Andreevich

Younger Researcher of the Department

of Agricultural Technologies

FSBSI «National Grain Center named

After P.P. Lukyanenko», 350012 Krasnodar-12, KNIISH C/B 
DOI 10.33775/1684-2464-2021-50-1-25-29

УДК 633.18:631.257: 631.526.32
Остапенко Н. В., канд. с.-х. наук, Джамирзе Р. Р., канд. с.-х. наук, Чинченко Н. Н. г. Краснодар, Россия

\section{НОВЫЙ СОРТ РИСА ДИАЛОГ}

Селекция крупнозерных сортов риса с высокими технологическими показателями крупы сопряжена с обеспечением отечественной пищевой промышленности конкурентоспособной продукцией. Создание и внедрение в производство новых и более урожайных сортов риса приобретают всё большую актуальность, поскольку это одна из главных причин увеличения урожайности. Своевременная сортосмена является главным фактором, определяющим прогресс в рисоводстве. В статье представлены результаты работы по созданию нового крупнозёрного сорта риса Диалог. Дана сравнительная характеристика за три года (2018-2020 гг.). Установлено превосходство нового сорта над стандартом по комплексу признаков: по урожайности новый сорт Диалог достоверно превысил Фаворит и сформировал 112,4 ц/га; продуктивность одного дня вегетации на 13,7 кг/дн./га больше чем у стандарта при озерненности агрофитоценоза 51,26 тыс.шт./M²; при одинаковой длине главной метелки сорт Диалог сформировал превосходящее количество колосков - 155,5 шт., чем обусловлена большая плотность метелки 9,5 шт./см. Технологические показатели качества зерна и крупы, а также поражаемость пирикуляриозом при искусственном заражении у него (28,9 \%) на уровне стандарта (30,6 \%). По итогам многолетней оценки, сорт Диалог передан на государственное испытание (ГСИ) на 2021 год. Положительная оценка на ГСИ позволит внести его в Госреестр и рекомендовать к возделыванию в условиях Краснодарского края и Республики Адыгея, Ростовской области и Дагестана.

Ключевые слова: рис, селекция, крупнозерный сорт, технологические показатели качества крупы.

\section{NEW RICE VARIETY DIALOG}

Breeding of large-grain rice varieties with high technological parameters of milled rice is associated with providing the domestic food industry with competitive products. Development and introduction of new and more productive rice varieties are becoming increasingly important, since this is one of the main reasons for increasing yields. Timely variety change is the main factor in determining progress in rice production. The article presents the results of work on development of a new large-grain rice variety Dialog. A comparative characteristic is given for three years (2018-2020). The superiority of the new variety over the standard was established in terms of a set of traits: in terms of yield, the new variety Dialog significantly exceeded Favorit and formed 112.4 centners/ha; the productivity of one day of growing season is $13.7 \mathrm{~kg} /$ day/ha more than that of the standard with a grain content of the agrophytocenosis of 51.26 thousand pieces $/ \mathrm{m}^{2}$; with the same length of the main panicle, Dialog has formed a superior number of spikelets - 155.5 pcs., which determines the panicle high density - $9.5 \mathrm{pcs} / \mathrm{cm}$. Technological quality traits of grain and milled rice, as well as the susceptibility to blast disease in case of artificial infection (28.9\%) are at the standard level (30.6\%).

Based on the results of a long-term assessment, the variety Dialog was submitted for state testing (SVT) for 2021. A positive assessment in the SVT will allow it to enter into the State Register and be recommended for cultivation in Krasnodar Region and the Republic of Adygea, Rostov Region and Dagestan.

Key words: rice, breeding, large-grain variety, technological indicators of milled rice quality.

\section{Введение}

Роль сорта в получении урожая исключительно велика [3]. Сортосмена - важнейший процесс, от своевременного и научно-обоснованного проведения которого во многом зависит успех растениеводства, в том числе и рисоводства. Для получения стабильно высоких результатов в отрасли необходимо обновлять структуру посевных площадей риса максимально эффективными сортами, соответствующими данной агроклиматической зоне.

Тенденция последних лет - устойчивое повыше- ние спроса на крупу риса крупнозерных сортов, не могла не отразиться на направлении работы селекционеров. Из переданных на ГСИ в 2017 году пяти сортов три являются крупнозёрными, в 2018 году - два из пяти, в 2019-м - два из четырех [5].

В научно обоснованной технологической системе возделывания сельскохозяйственных растений селекция и семеноводство занимают ведущее место как наиболее мощные, экологически безвредные рычаги в повышении урожайности и качества растениеводческой продукции [4]. По имеющимся оценкам, вклад 
селекции в повышение урожайности сельскохозяйственных культур за последние десятилетия оценивается в 30 - 70 \%, а с учетом возможных изменений климата роль селекции будет возрастать [8, 13]. Селекция и внедрение в производство новых, более урожайных сортов, является одним из факторов, способствующих росту эффективности рисоводства [1]. Во многом рост урожайности и валовых сборов, а также повышение технологических показателей зерна и крупы обеспечивается внедрением новых сортов риса, в основном интенсивного типа, что в свою очередь обусловливает эффективность отрасли.

Для прогрессивного развития рисоводства необходима научно-обоснованная сортовая политика, включающая наращивание ассортимента возделываемых сортов разной технологической энергоемкости (сорта интенсивного, экстенсивного и промежуточного типов), учитывающая характерные им особенности, а также агроклиматические условия возделывания [5, 12].

Поэтому в рамках НИР ФГБНУ «ФНЦ риса» проводит масштабные экологические и производственные испытания на территории России и ближнего зарубежья с целью оптимального подбора и размещения сортов риса нового поколения [7].

Наивысшие результаты в последние годы достигнуты Краснодарским краем в области рисоводства благодаря эффективной селекционной работе, быстрой своевременной сортосмене и внедрению адаптивных сортовых комплексов с учетом агроландшафтного районирования [2].

Рост урожайности и валовых сборов риса в Республике Адыгея связывают с тесным сотрудничеством с учёными. В 2018 году семена селекции ФНЦ риса заняли около 41,4 \% посевной площади в Республике Адыгея, что на 30 \% больше, чем в 2017 г. [11].

В Республике Адыгея в 2019 году площадь посевов риса довели до 8,2 тыс. га. Наблюдается положительная динамика. В 2017 году посевные площади риса составляли 5,1 тыс. га, в 2018 году - почти 6,7 тыс. га. В 2018 году валовой сбор риса составил около 35 тыс. тонн [17].

\section{Цель исследований}

Оценить новые генотипы риса в конкурсном испытании и передать лучший из них на государственное сортоиспытание.

\section{Материал и методы}

Эксперимент проводили в условиях полевого опыта на рисовой оросительной системе ФГБНУ «ФНЦ риса». Погодные условия местности позволяют возделывать рис с продолжительностью вегетационного периода до 127 - 130 дней как по среднесуточной температуре воздуха в среднем за вегетацию $23,0^{\circ} \mathrm{C}$, так и теплообеспеченности (сумма активных температур $>15^{\circ} \mathrm{C}$ ) $-800-1100^{\circ} \mathrm{C}$. Преобладающий тип почв на опытном участке - лугово-черноземный. Содержание гумуса 2,8 - 3,4 \%.
Емкость поглощения невысокая - 32,0-34,0 мг-экв./ 100 г почвы. Преобладает в основном нейтральная, редко слабощелочная реакция почвенного раствора - $\mathrm{pH}=7,2$ - 7,6 .

Материалом для исследований послужил новый среднепозднеспелый сорт риса Диалог (ВНИИР 10279), полученный путем индивидуального отбора из гибридной комбинации Арборио/Анаит//Волано/ ВНИИР 10185 и изученный во всех звеньях селекционного процесса.

Полевой опыт закладывали по типу КСИ (конкурсное сортоиспытание) в соответствии с ГОСТ 15.101 .80 - «Порядок проведения научно-исследовательских работ» и методиками, разработанными в ФНЦ риса, и методикой опытных работ по селекции, в период 2018-2020 гг. [9, 10, 15] Сроки посева и первоначального залива чека - первая декада мая. Норма высева из расчета 7 млн. всхожих семян на 1 гектар. В 2018 году: предшественник чистый пар, минеральное питание $\mathrm{N}_{130} \mathrm{P}_{80}$. В 2019 году предшественник озимая пшеница, минеральное питание $\mathrm{N}_{144} \mathrm{P}_{104}$. В 2020 году предшественник озимая пшеница, минеральное питание $\mathrm{N}_{130} \mathrm{P}_{80}$.

Опытные делянки закладывали в четырехкратной повторности, размещение - рендомизированные повторения, сорт стандарт - Фаворит (крупнозерный). Площадь делянок 18,2 м² (длина 15,2 м, ширина 1,2 м). Количество рядков в делянке - восемь, расстояние между рядами $15 \mathrm{~cm}$, расстояние между делянками 40 и 50 см.

Технологические характеристики зерна и крупы определяли по ГОСТ 10843-76, ГОСТ 10987-76 и «Методическим указаниям по оценке качества зерна риса» [14]. Достоверность полученных данных подтверждается результатами дисперсионного анализа $[6,16]$.

\section{Результаты и обсуждение}

Основным фактором при выборе перспективного сорта риса является оптимальное сочетание характеризующих его хозяйственно ценных признаков (табл.).

Из таблицы видно, что сорт Диалог достоверно превысил Фаворит (st) по урожайности на 16,5 ц/га в среднем за три года, по продуктивности одного дня вегетации на 13,7 кг/дн.га, сформировал большее количество колосков - 155,5 шт. и соответственно плотность главной метелки - 9,5 шт./см при аналогичных значениях технологических показателей качества зерна и крупы, а также поражаемости пирикуляриозом при искусственном заражении.

Масса 1000 зерен нового сорта 30,7 г, что меньше, чем у стандарта Фаворит, но позволяет относить его к крупнозерным, и поэтому сравнивать с соответствующим сортом.

Происхождение (генеалогию) нового сорта риса Диалог (ВНИИР 10279) можно проследить на разных этапах селекционной работы (рис.). 
Таблица. Сравнительная характеристика сортов риса, 2018-2020 гг.

\begin{tabular}{|c|l|c|c|c|}
\hline \multicolumn{1}{|c|}{ Поизнак } & Фаворит (st) & Диалог & + +/- к стандарту \\
\hline 1 & Урожайность, ц/га & 95,9 & 112,4 & 16,5 \\
\hline 2 & НСР & & 6,03 & 13,7 \\
\hline 3 & Продуктивность одного дня вегетации, кг./дн.га & 81,1 & 94,8 & 11,80 \\
\hline 4 & Озерненность агрофитоценоза, тыс.шт./м & 39,45 & 51,26 & 0,0 \\
\hline 5 & Вегетационный период, дн. & 119 & 119 & $-6,0$ \\
\hline 6 & Высота растения, см & 101,2 & 95,2 & $-0,3$ \\
\hline 7 & Длина главной метелки, см & 16,7 & 16,4 & 6,8 \\
\hline 8 & Количество выполненных колосков, шт. & 148,0 & 155,5 & 0,6 \\
\hline 9 & Плотность, шт./см & 8,9 & 9,5 & 6,4 \\
\hline 10 & Стерильность, \% & 13,8 & 20,2 & $-0,2$ \\
\hline 11 & Отношение длины к ширине зерновки (І/b) & 2,3 & 2,1 & $-3,6$ \\
\hline 12 & Масса 1000 зерен, при 14\% & 34,3 & 30,7 & 1,4 \\
\hline 13 & Пленчатость, \% & 18,2 & 19,6 & 5,3 \\
\hline 14 & Стекловидность, \% & 82,0 & 87,3 & 0,8 \\
\hline 15 & Общий выход крупы, \% & 69,3 & 70,1 & 1,8 \\
\hline 16 & Содержание целого ядра в крупе, \% & 85,9 & 87,7 & $-1,7$ \\
\hline 17 & Индекс развития болезни (ИРБ), \% & 30,6 & 28,9 & \\
\hline
\end{tabular}

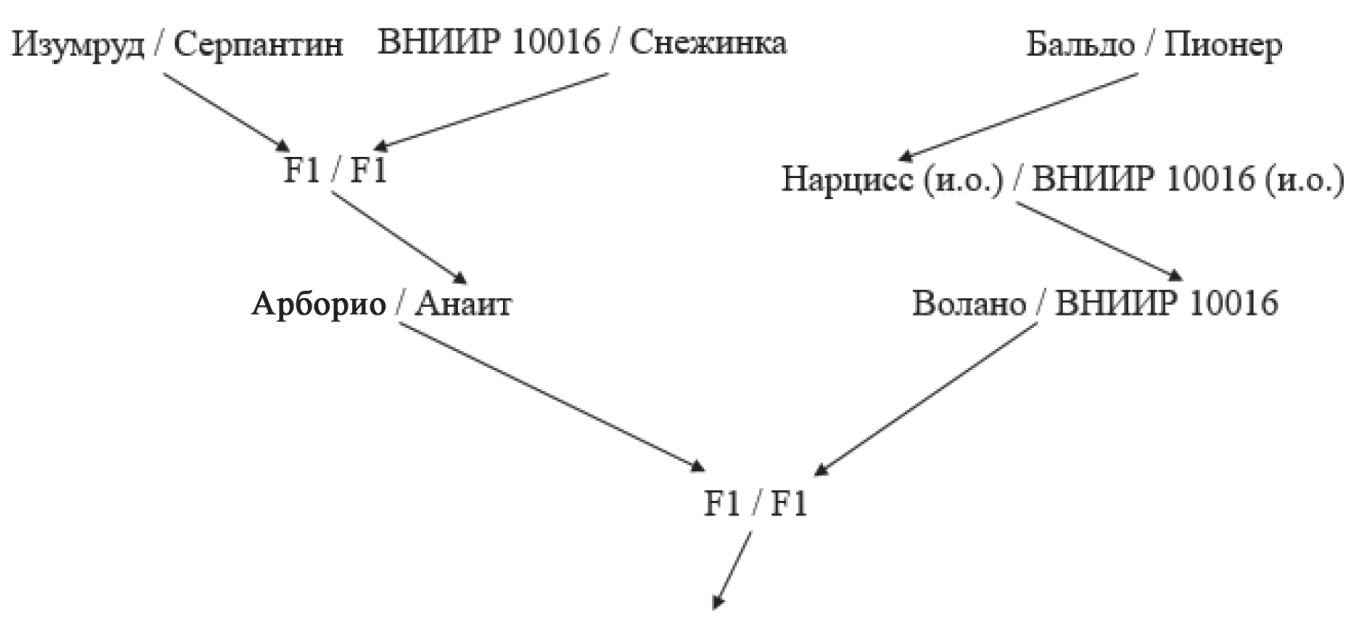

ВНИИР 10279 Диалог

Рисунок. Генеалогия сорта риса Диалог

При подготовке сорта Диалог к передаче на ГСИ в 2020 году была составлена и передана соответствующая характеристика по основным хозяйственно ценным признакам.

Характеристика сорта Диалог (ВНИИР 10279)

Среднепозднеспелый, среднезёрный сорт риса Диалог создан методом идивидуального отбора из гибридной комбинации с известными крупнозёрными сортами: Арборио/Анаит//Волано/ВНИИР 10185.

Oryza sativa L., subcp. Japonica, var. italica Alef.

Вегетационный период 116-118 дней.

Высота растений 90-98 см. Стебель прочный, средней толщины, устойчив к полеганию. Куст плотный, вертикальный, продуктивная кустистость 2,0-3,0 побега.
Метёлка наклонная (5), среднеразвесистая (5), плотная (колосков 11-12 шт./см), длиной 17-18 см. Общее количество колосков - 192 шт. Пустозёрность - 11-13 \%. Зерновка полуудлиненная (l/b $2,0-2,1)$ без остей, соломенно-желтого цвета. Ножка метёлки средней толщины, прочная, выходит из влагалища листа на 1-5 см.

Листья темно-зелёные, по величине промежуточные. Средней ширины короткий флаговый лист отходит от оси стебля на 30-40 градусов.

Масса 1000 зёрен при влажности 14 \% 30,5-31,0 г, плёнчатость - 19,6 \%; стекловидность - 93 \%; общий выход крупы - 70,8 \%; содержание целого ядра в крупе - 85,7 \%. Каша белая, полурассыпчатая, хорошего и отличного вкуса.

Сорт Диалог к пирикуляриозу среднеустойчив 
при искусственном заражении с интенсивностью развития болезни 37,0 \%. На естественном фоне поражение пирикуляриозом не наблюдалось.

Имеет средние темпы роста в начальный период.

Холодоустойчивость у Диалога 4 балла - на уровне сорта-индикатора Кубань 3.

Устойчивость к полеганию высокая. Не осыпается, но легко обмолачивается.

Урожайность по годам изучения (2017-2019 гг.) варьировала в пределах 80-120 ц/га.

Условно-чистый доход от внедрения среднеспелого урожайного сорта риса Диалог может составить 20 тысяч рублей на 1 гектар.

Рекомендуемые регионы возделывания Краснодарский край, Республика Адыгея, Ростовская область, Дагестан.

\section{Выводы}

По итогам многолетней оценки новых генотипов риса в КСИ, сорт Диалог характеризовался рядом преимуществ в сравнении со стандартом: сформировалдостоверновысокуюурожайность-112,4ц/га; максимальное значение продуктивности одного дня вегетации - 94,8 кг./дн.га при наибольшей озерненности агрофитоценоза - 51,26 тыс.шт./м²; также при одинаковой длине главной метелки сформировал превосходящее количество колосков - 155 шт., чем обусловлена большая ее плотность - 9,5 шт./м; основные технологические показатели качества зерна и крупы на уровне стандарта.

Учитывая вышеприведенные особенности сорта Диалог, нами было принято решение передать его на ГСИ на 2021 год, так как он оптимально сочетает в себе главные признаки, интересующие производство: урожайность, относительную крупнозерность и хорошее качество крупы при средней устойчивости к пирикуляриозу в условиях искусственного заражения.

\section{ЛИТЕРАТУРА}

1. Алешин, Е.П. Рис / Е.П. Алешин, Н.Е. Алешин М.: 1993. - 505 с.

2. Гаркуша, С.В. Пути адаптации растениеводства к изменениям климата / С. В. Гаркуша // Материалы международной научно-практической конференции с элементами молодых ученых «Научные приоритеты адаптивной интенсификации сельскохозяйственного производства». - Краснодар: ФГБНУ «ВНИИ риса», 2019. - С. 3-7.

3. Гуляев, Г.В. Селекция и семеноводство полевых культур с основами генетики / Г. В. Гуляев, А. П. Дубинин. М.: «Колос», 1969. - 487 с.

4. Джамирзе, Р.Р. Корреляция признаков и их изменчивость в селекции риса / Р.Р. Джамирзе, Н.В. Остапенко // Научный журнал «Труды КубГАУ», выпуск, посвященный столетию Факультета Агрономии и Экологии. - 2018. - № 5 (74). - C. 25-32.

5. Джамирзе, Р.Р. Изменчивость хозяйственно ценных признаков новых сортов риса в конкурсном испытании / Р.Р. Джамирзе, Н.В. Остапенко, Н.Н. Чинченко // Известия горского государственного аграрного университета. 2019. - № 56 (1). - С. 19-25.

6. Дзюба, В.А. Многофакторные опыты и методы биометрического анализа экспериментальных данных. Методические рекомендации / В.А. Дзюба. Краснодар. - 2007. - 76 с.

7. Есаулова, Л.В. Научные приоритеты адаптивной интенсификации производства риса в Российской Федерации / Л.В. Есаулова, С.В. Гаркуша, С.В. Кизинек // Материалы международной научно-практической конференции с элементами молодых ученых «Наусные приоритеты адаптивной интенсификации сельскохозяйственного производства». - Краснодар: ФГБНУ «ВНИИ риса», 2019. - С. 34-36.

8. Жученко, А.А. Ресурсный потенциал производства зерна в России (теория и практика) / А.А. Жученко. - М.: Издательство «Агрорус», 2004. - 1109 с.

9. Зеленский, Г.Л. Рис. Новые сорта риса и энергосберегающие технологии его возделывания в Краснодарском крае / Зеленский Г.Л., Чеботарев М.И., Трубилин Е.И. [и др.] - Краснодар, 1997. - 95 с.

10. Ковалёв, В.С. Совершенствование методики и техники закладки конкурсного сортоиспытания риса / В.С. Ковалёв, Н.В. Остапенко // Тезисы докладов конференции молодых ученых и специалистов. - Краснодар, 1987. C. $10-12$.

11. Лысенко, Ю.А. Проблемы и перспективы рисоводства на примере Краснодарского края и республики Адыгея / Ю.А. Лысенко, И.Н. Чуев, В.А. Хрисониди // Фундаментальные исследования. - 2019. - № 4. - С. 66-70.

12. Малышева, Н.Н. Аспекты развития отрасли рисоводства / Н.Н. Малышева, С.А. Гаркуша // Сборник научных трудов по итогам IV международной научно-практической конференции «Новые тенденции развития сельскохозяйственных наук» - г. Ростов - на-Дону, 2017. - С. 18-21.

13. Моисеев, В.В. К вопросу о повышении экономической эффективности выращивания зерновых культур в Краснодарском крае путем развития селекции и семеноводства / В.В. Моисеев // Развитие АПК. - 2007. - №7 (46). - C. 139-144.

14. Романов, В.Б. Методические указания по оценке качества зерна риса / В.Б. Романов. Краснодар: ВНИИ риса, 1983. - 22 с.

15. Сметанин, А.П. Методики опытных работ по селекции, семеноводству и контролю за качеством семян риса / А.П. Сметанин, В.А.Дзюба, А.И. Апрод. - Краснодар, 1972. - 186 с.

16. Шеуджен, А.Х. Методика агрохимических исследований и статистическая оценка их результатов: учебное пособие. 2-е изд. переработанное и дополненное / А.Х. Шеуджен, Т.Н. Бондарева Майкоп: ОАО «Полиграф-ЮГ», 2015. -664 c. 
17. В Адыгее на 22\% увеличат площадь посевов риса. URL: https://www.yuga.ru/news/441575.

\section{REFERENCES}

1. Aleshin, E.P. Rice / E.P. Aleshin, N.E. Aleshin M.: 1993. - 505 p.

2. Garkusha, S.V. Ways of adapting crop production to climate change / S. V. Garkusha // Materials of the international scientific-practical conference with elements of young scientists school "National priorities for adaptive intensification of agricultural production." - Krasnodar: FSBSI "ARRRI", 2019. - P. 3-7.

3. Gulyaev, G.V. Breeding and seed production of field crops with the basics of genetics / G.V. Gulyaev, A.P. Dubinin. M.: "Kolos", 1969. - 487 p.

4. Dzhamirze, R.R. Correlation of traits and their variability in rice breeding / R.R. Dzhamirze, N.V. Ostapenko // Scientific journal "Proceedings of the KubSAU", issue dedicated to the centenary of the Faculty of Agronomy and Ecology. - 2018. - № 5 (74). - P. 25-32.

5. Dzhamirze, R.R. Variability of economically valuable traits of new rice varieties in competitive testing / R.R. Dzhamirze, N.V. Ostapenko, N.N. Chinchenko // Journal of proceedings of the Gorsky SAU. - 2019. - № 56 (1). - P. 19-25.

6. Dzyuba, V.A. Multifactor experiments and methods of biometric analysis of experimental data. Methodical recommendations / V.A. Dzyuba. Krasnodar, 2007. - 76 p.

7. Esaulova, L.V. Scientific priorities of adaptive intensification of rice production in the Russian Federation / L.V. Esaulova, S.V. Garkusha, S.V. Kizinek // Materials of the international scientific-practical conference with elements of young scientists school "National priorities for adaptive intensification of agricultural production." - Krasnodar: FSBSI "ARRRI", 2019. - P. 34-36.

8. Zhuchenko, A.A. Resource potential of grain production in Russia (theory and practice) / A.A. Zhuchenko. - M .: Publishing house "Agrorus", 2004. - 1109 p.

9. Zelensky, G.L. Rice: New rice varieties and energy-saving technologies for their cultivation in Krasnodar region / Zelensky G.L., Chebotarev M.I., Trubilin E.I. [et.al.] - Krasnodar, 1997. - 95 p.

10. Kovalev, V.S. Improvement of the methodology and technique of laying a competitive rice variety testing / V.S. Kovalev, N.V. Ostapenko // Abstracts of the conference of young scientists and specialists. - Krasnodar, 1987. - P. 10-12.

11. Lysenko, Yu.A. Problems and prospects of rice growing on the example of Krasnodar region and the Republic of Adygea / Yu.A. Lysenko, I.N. Chuev, V.A. Chrysonidi // Fundamental research. - 2019. - № 4. - P. 66-70.

12. Malysheva, N.N. Aspects of the development of rice growing industry / N.N. Malysheva, S.A. Garkusha // Collection of scientific papers on the results of the IV international scientific and practical conference "New trends in the development of agricultural sciences". Rostov-on-Don, 2017. - P. 18-21.

13. Moiseev, V.V. On the issue of increasing the economic efficiency of growing grain crops in Krasnodar region through the development of breeding and seed production / V.V. Moiseev // Development of the agro-industrial complex. - 2007. - № 7 (46). - P. 139-144.

14. Romanov, V.B. Guidelines for assessing the rice grain quality / V.B. Romanov. Krasnodar: ARRRI. $1983 .-22$ p.

15. Smetanin, A.P. Techniques for experimental work on breeding, seed production and quality control of rice seeds / A.P. Smetanin, V.A. Dzyuba, A.I. Aprod. - Krasnodar, 1972. - 186 p.

16. Sheudzhen, A.Kh. Agrochemical research methodology and statistical evaluation of their results: textbook, 2-nd edition, revised and enlarged / A.Kh. Sheudzhen, T.N. Bondareva Maykop: OJSC Polygraph-YUG, 2015. - 664 p.

17. In Adygea, the area of rice crops will be increased by $22 \%$. URL: https://www.yuga.ru/news/441575.

\section{Остапенко Надежда Васильевна}

Ведущий научный сотрудник отдела селекции

\section{Джамирзе Руслан Рамазанович}

Старший научный сотрудник отдела селекции

\section{Чинченко Наталья Николаевна}

Младший научный сотрудник отдела селекции

Все: ФГБНУ «ФНЦ риса»

E-mail: arrri_kub@mail.ru

350921, Россия, Краснодар, Белозерный, 3

\section{Ostapenko Nadezhda Vasilievna}

Leading researcher of breeding department

\section{Dzhamirze Ruslan Ramazanovich}

Senior scientist of breeding department

\section{Chinchenko Natalia Nikolaevna}

Junior scientist of breeding department

All: FSBSI «Federal Scientific Rice Centre»

E-mail: arrri_kub@mail.ru

3, Belozerny, Krasnodar, 350921 Russia 
DOI 10.33775/1684-2464-2021-50-1-30-34

УДК 631.53.02:633.18 УДК 631.53.02:633.18
C.В. Гаркуша, д-р с.-х. наук, профессор,

C.A. Тешева, канд. биол. наук,

Д.А. Пищенко

г. Краснодар, Россия

\section{ЭФФЕКТИВНОСТЬ БЕСПРОПОЛОЧНОЙ ТЕХНОЛОГИИ ВЫРАЩИВАНИЯ ЭЛИТНЫХ СЕМЯН РИСА В КРАСНОДАРСКОМ КРАЕ}

Важным условием при внедрении новых сортов риса в производство является высокоэффективная система семеноводства, обеспечивающая производство качественного семенного материала в объёмах, необходимых для сортосмены и сортообновления. Одним из важнейших технологических приемов при выращивании элитных семян является сортовая прополка, при которой из посева вручную удаляются растения других сортов и краснозерных форм, которые являются злейшими засорителями посевов риса. Примесь краснозерных форм в оригинальных и элитных семенах не допускается. Исследования проводились с целью разработки беспрополочной системы производства элитных семян, основными элементами которой являются эффективные в борьбе с падалицей краснозерных форм способы подготовки почвы под посев риса и использование для посева высококачественных оригинальных семян. Проведен анализ состояния засоренности посевов риса краснозерными формами, семенного материала и почвы, рассмотрены различные варианты предпосевной обработки почвы в борьбе с падалицей краснозерных форм риса. Выявлен наиболее эффективный способ обработки почвы в борьбе с краснозерными формами риса в семенных посевах, при котором урожайность повышается, а засоренность посевов и получаемого зерна риса существенно снижается. При изучении использования схем беспрополочной системы семеноводства выявлено, что эффективными агротехническими приемами, способствующими снижению уровня засоренности посевов и зерна риса и обеспечивающими повышение урожайности и валового сбора является лущение и весновспашка. В сравнении с вариантом с весновспашкой и дискованием почвы в 2 следа лущение стерни уменьшает засоренность посевов на 4,9-5,2 \%, зерна - на 4,4-4,6 \%, полученного семенного материала на 0,1-0,3%. Это позволяет снизить затраты ручного труда при производстве семян, улучшить их качество и сортимент, ускорить сортосмену и сортообновление.

Ключевые слова: рис, сорт, оригинальные семена, краснозерные формы риса, питомник размножения семян, репродукция, сортосмена, беспрополочная технология, урожайность.

\section{EFFICIENCY OF WEEDING-FREE TECHNOLOGY FOR GROWING ELITE RICE SEEDS} IN KRASNODAR REGION

An important condition for the introduction of new rice varieties into production is a highly efficient seed production system that ensures the production of high-quality seed material in the volumes required for variety change and variety renewal. One of the most important technological methods in the cultivation of elite seeds is varietal weeding, in which plants of other varieties are manually removed from the crop and, most importantly, plants of red-grain forms, which are the worst weeds for rice crops. The admixture of red-grain forms in original and elite seeds is not allowed. The aim of the research is to develop a weeding-free system for the production of elite seeds, the main elements of which are methods of preparing the soil for sowing rice effective in the fight against carrion of redgrain forms and using high-quality original seeds for sowing. The analysis of the state of infestation of rice crops with red-grain forms was also revealed, both in the seed material itself and in the soil, various options for pre-sowing soil cultivation in the fight against carrion of red-grain forms of rice were considered. The most effective method of soil cultivation in the fight against red-grain forms of rice in seed crops, in which the yield increases, and the weediness of crops and the resulting rice grain, is significantly reduced, has been revealed. When studying the use of schemes for a weeding-free seed production system, it was revealed that stubble and spring plowing are effective agricultural practices that help reduce the level of contamination of crops and rice grains and ensure an increase in yield and gross harvest. In comparison with the option with spring plowing and disking of the soil in 2 tracks, stubble plowing reduces weediness of crops by 4.9-5.2 \%, grain - by 4.4-4.6 \%, obtained seed material by 0.1-0.3\%. This makes it possible to reduce the costs of manual labor in the production of seeds, improve their quality and assortment, and speed up the variety change and variety renewal.

Key words: rice, variety, original seeds, red-grain rice forms, multiplication nursery, reproduction, variety change, weeding-free technology, yield. 


\section{Введение}

Одним из важнейших факторов дальнейшего развития рисоводства в Краснодарском крае является повышение эффективности отрасли путем внедрения в производство новых перспективных сортов риса с высокой урожайностью и технологическими качествами. Значительная роль в этом вопросе принадлежит семеноводству, которое включает систему мероприятий, направленных на получение семян сортов риса высоких посевных кондиций в необходимом для Краснодарского края объёме, сохранение их сортовых качеств, безопасное хранение семенного материала и контроль его качества $[1,9]$.

В целях сохранения сортовых и посевных качеств репродукционных семян, ценных хозяйственно-технологических свойств сорта, предотвращения распространения заболеваемости растений проводится сортообновление, которое является обязательным для всех сельскохозяйственных товаропроизводителей [5, 10].

Разработанная для риса система сортообновления предусматривает приобретение рисоводческими хозяйствами элитных семян и их размножение на участках, составляющих от 8 до 10 \% от общей площади посевов риса, что исключает использование в хозяйствах семян второй, и тем более, третьей репродукции [12]. Такая система сортообновления позволяет существенно снизить засоренность товарного риса краснозерными формами, повысить урожайность риса.

Формы риса, засоряющие посевы его культуры в Краснодарском крае, по систематическому положению относятся к тому же виду, что и культурный рис Oryza sativa L., но имеют окрашенный перикарп. Эти формы обладают нежелательными для рисоводов агробиологическими признаками, такими как полегаемость, осыпаемость колосков, низкое качество зерна, восприимчивость к болезням. По данным А.Н. Апрода и Ф.А. Колесникова к началу 70-х гг. прошлого века в Краснодарском крае в посевах риса распространены были остистые краснозерные разновидности [2].

В исследованиях Зеленской О.В. по изучению на посевах риса в Краснодарском крае краснозерных форм к началу 2001 году выявлено 8 разновидностей, относящихся к подвиду Japonika и 1 - к подвиду Indika. Семена сорно-полевых растений риса по форме, размеру и часто по цвету цветковых чешуй обычно мало отличаются от семян культурного риса, что создает определенные трудности при ведении семеноводства [6].

Традиционными методами борьбы с сорняками являются механическая и химическая прополки. Кроме того, необходимо использовать для посева только сертифицированные семена выращиваемых сортов. Если не проводится сортовая прополка, то содержание красных зерен в посевном материале значительно возрастает. Сортовая прополка проводится, как правило, дважды и сопряжена с большими затратами тяжелого ручного труда. Однако борьба с сорными формами риса методом ручной прополки затруднена из-за сходства неосыпающихся сорно-полевых форм с возделываемыми сортами риса по большинству морфологических признаков. Это привело к снижению урожайности риса ввиду высокой конкурентоспобности сорного риса. Данная проблема существует и в других рисосеющих странах мира, в которых использовался механизированный прямой высев семян в почву. Так, в европейских странах (Италия, Испания) и в США растения сорного риса в отличие от районированных сортов лучше адаптированы к меняющимся условиям окружающей среды, обладают большой вариабельностью, что приводит к засорению посевов и потерям урожая [6, 7, 11 15]. В штате Аризона (США) были проведены исследования воздействия трех биотипов сорного риса на рост и развитие ряда возделываемых сортов в США, в результате чего выявлено снижение урожайности от 100 до 750 кг/га в расчёте на каждое растение риса/м² [6, 13, 16].

В мировой практике наиболее эффективные меры борьбы с краснозерным рисом основаны на сочетании агротехнических приемов и химических мер борьбы [6, 12, 14, 15, 17].

Краснозерные сорно-полевые формы распространяются в основном при посеве риса нечистосортными семенами, при несоблюдении севооборота и выращивании зерна для товарных целей (т.е. отсутствие сортовых прополок). В результате исследований Зеленской О.В., Максименко Е.П. установлено, что в последние годы на Кубани в посевах риса распространились растения сорного риса с неосыпающимися колосками и окрашенным перикарпом зерна. Высота этих растений, форма метелки, сроки наступления основных фенологических фаз сопоставимы с районированными сортами риса. Из-за отсутствия эффективных методов борьбы в течение последних лет производственные посевы риса в Краснодарском крае оказались засоренными растениями нового биотипа краснозерного риса $[6,7,8]$.

Главным средством борьбы с краснозерными формами риса является поддержание сортовой чистоты во всех звеньях семеноводства и своевременное проведение сортообновления и сортосмены. В решении проблемы борьбы с краснозерными формами риса необходимо использовать системный подход, разработка беспрополочной системы производства семян.

\section{Цель исследований}

Изучить агротехнические приемы, способствующие снижению уровня засоренности посевов и зерна риса, обеспечивающие повышение урожайности и валового сбора для разработки беспрополочной системы производства семян.

\section{Материалы и методы}

Для разработки элементов беспрополочной системы производства семян, проведены исследования в полевом опыте, заложенном в ФГБУ РПЗ «Красно- 
армейский» им. Майстренко А.И. Красноармейского района - филиал ФГБНУ «ФНЦ риса». Изучались три варианта предпосевной обработки почвы:

1) лущение (безотвальная обработка на глубину 12-14 см, ПЧН-3,2М);

2) весновспашка (отвальная обработка на глубину $15-18$ см);

3) дискование в 2 следа на глубину 8-10 см (БДТ-7).

Повторность в опыте - 4-х кратная. Площадь делянки - 0,55 га. Учетная площадь делянки - 50 м². Норма высева семян 7,0 млн. всхожих зерен на 1 гектар. Предшественник - озимая пшеница.

Материалом исследований служил сорт риса Исток.

Перед посевом риса поверхность чека была выровнена при помощи планировщика Д - 71А и движки.

В качестве основного удобрения было внесено: аммофос - 50 кг/га; карбамид - 100 кг/га. Удобрения вносили перед движкованием почвы.

Осенью 2019 года был произведен подсчет количества осыпавшихся на поверхность чека красных зерен на десяти площадках площадью 0,25 м² по каждой диагонали чека. Определение засоренности высеянных семян и полученного зерна проводили по методике ФНЦ риса. Наблюдения и учеты в течение вегетации выполнялись по принятым для полевых опытов методикам [4]. В фазу полной спелости риса определяли засоренность посевов риса краснозерными формами по вариантам опыта. Для этого на 4 площадках по $1 \mathrm{~m}^{2}$, по диагонали каждой делянки подсчитано общее количество развитых стеблей риса и количество стеблей краснозерных форм.

Учет урожая проведен при сплошном обмолоте риса комбайном «Торум».

Статистическая обработка полученных данных проведена с использованием методов анализа экспериментальных исследований $[4,11,12,13]$.

\section{Результаты и обсуждение}

Одним из основных показателей, наряду со всхожестью и частотой семян, является степень засоренности семенами сорно-полевых форм, среди которых преобладают краснозерные разновидности. При их наличии снижается качество зерна. Одним из источников засорения является примесь красных зерен в посевном материале. Засорение возрастает с увеличением срока использования семян в хозяйстве. В посевной материал краснозерные формы попадают при уборке засоренных посевов риса, а также при складировании, послеуборочной обработке, сушке, хранении и посеве, если не приняты меры по недопущению смешивания сортов и различных репродукций. Вместе с тем источником засорения посевов риса краснозерными формами является и почва. При уборке урожая метелки краснозерных форм осыпаются и большое количество семян попадает на поверхность почвы. При вспашке, планировке и предпосевной обработке красные зерна заделываются в почву на различную глубину. Значительное количество семян сохраняют жизнеспособность в течение всей зимы и весной дают всходы (падалица). Всходы падалицы краснозерных форм обычно появляются раньше, чем всходы районированных сортов риса и дают жизнеспособные продуктивные семена, которые засоряют посевы.

Согласно техническим требованиям к качеству семян ГОСТ Р 52325-2005 «Семена сельскохозяйственных растений. Сортовые и посевные качества. Общие технические условия» содержание красных зерен в посевах ОС и ЭС риса не допускаются. В репродукционных семенах (РС, РСТ) примесь таких форм риса не должна превышать соответственно 0,5 \% и 1,0 \% [3]. Поэтому в данном полевом опыте высевались репродукционные семена сорта Исток (PC $)_{1}$ для выявления возможного снижения краснозерных форм риса.

Перед посевом определялась засоренность семян изучаемых сортов риса краснозерными формами, которая составила 0,5 \%. В фазу полной спелости определяли засоренность в вариантах опыта, она составила от 2,5 до 7,1%. Наибольшей она была на варианте с применением дискования стерни (табл. 1).

Таблица 1. Засоренность риса краснозерными формами при разных способах предпосевной обработки почвы, 2020 г.

\begin{tabular}{|l|c|c|c|c|}
\hline \multirow{2}{*}{\begin{tabular}{c} 
Варианты обработок \\
\cline { 2 - 5 }
\end{tabular}} & $\begin{array}{c}\text { высеянных } \\
\text { семян }\end{array}$ & посевов & зерна & $\begin{array}{c}\text { семенного } \\
\text { материала }\end{array}$ \\
\hline Весновспашка 15-18 см & 0,5 & 5,8 & 2,7 & 0,6 \\
\hline Лущение стерни на 12-14 см & 0,5 & 5,5 & 2,5 & 0,4 \\
\hline Дискование почвы в 2 следа на 8-10 см & 0,5 & 10,2 & 7,1 & 0,7 \\
\hline $\mathrm{HCP}_{0,5} 2,51$ & & \\
\hline
\end{tabular}

На рост развития засоренности посевов оказывают количество падалицы краснозерных форм риса и краснозерные биотипы районированных сортов, которые дают полноценные растения засорителя. В варианте с применением дискования стерни засоренность краснозерными формами риса больше чем при весновспашке и лущении стерни, так как семена падалицы при этом большой частью заделываются на глубину до 10 см при которой не снижается их всхожесть, что подтверждено ранее проведенными исследованиями [7, 10].

При изучении ботанического состава популяции краснозерных форм, засоряющих посевы, выявлено, что высокорослые остистые формы представле- 
ны единичными растениями в отдельных чеках, а в опыте - не обнаружено. Полуостистые, низкорослые (80-90 см) формы не превышают 0,2-0,7 \%. Основными засорителями являются низкорослые, осыпающиеся и слабоосыпающиеся формы разновидности Sundensis Koen (70-80 \%). Неосыпающиеся формы этой разновидности, не отличаются по морфологическим признакам от растения сорта Исток (краснозерные биотипы), занимают в популяции от 5 до 10 \% являются проблемой в получении чистосортных семян этого сорта, так как при сортовых прополках практически не удаляются.

Во время уборки были отобраны образцы зерна для определения его влажности, чистоты и содержания в нем семян краснозерных форм. Результаты анализа показали, что засоренность зерна риса варьировала от 5,5 \% (при лущении стерни) до 10,2 \% (при дисковании почвы) (табл. 1).

Анализ засоренности полученных семян риса краснозерными формами выявил снижение по вариантам обработки почвы на 0,1-0,2 \% в сравнении с засоренностью высеваемых семян. В варианте с лущением стерни и весновспашкой доля засорения семенного материала составила 0,4 и 0,6 \% соответственно, в варианте с проведением дискования почвы в два следа - 0,7 \%.

Засоренность посевов риса определяется не только качеством высеваемых семян, но и количеством сохранившей жизнеспособность падалицы после перезимовки, а также некоторого количества падалицы, сохранившей всхожесть с прошлых лет. Вместе с тем количество падалицы зависит от сроков уборки. На засоренность посевов краснозерными формами наряду с падалицей существенное влияние оказывает значительно более высокая устойчивость засорителя к слою воды в период получения всходов.

В фазу полных всходов и перед уборкой проведен подсчет густоты стояния растений риса (табл. 2).

Анализ приведенных данных показал, что способы обработки почвы на количество всходов и полевую всхожесть семян не влияют, но прослеживается увеличение этих показателей в варианте с проведением весновспашки (на 8,6 \% и 7,9 \%, соответственно). При этом в варианте с дискованием почвы в 2 следа количество всходов и полевая всхожесть были наименьшими. Это объясняется глубиной обработки и степенью измельчения почвы.

\section{ЛИТЕРАТУРА}

1. Апрод, А.И. Методические указания по производству семян элиты риса / А.И. Апрод, В.В. Куварин - М., 1989. - 28 C.

2. ГОСТ Р 52325-2005 «Семена сельскохозяйственных растений. Сортовые и посевные качества. Общие технические условия» - М.: Стандартинформ, 2005. - 24 с.

3. Доспехов, Б.А. Методика полевого опыта / Б.А. Доспехов - М.: Колос, 1985. -351 с.

4. Закон Краснодарского края «О регулировании отдельных отношений в сфере семеноводства на территории Краснодарского края» от 28 ноября 2014 года № 3062-КЗ / http://docs.cntd.ru/document/423854860 / дата обращения 20.12.2020 г.).

5. Методические указания по производству семян элиты зерновых, зернобобовых и крупяных культур. (справочно - методическое издание) //- М.: Колос, 1982.- 29 с.

6. Методические рекомендации по возделыванию сортов риса кубанской селекции / Авт. колл.: С.В. Гаркуша,
Таблица 2. Густота стояния и полевая всхожесть растений риса в фазу всходов при различных способах обработки почвы, шт./м², 2020 г.

\begin{tabular}{|l|c|c|}
\hline Варианты обработок & $\begin{array}{c}\text { Количество } \\
\text { растений, } \\
\text { шт./м² }\end{array}$ & $\begin{array}{c}\text { Полевая } \\
\text { всхожесть, } \\
\text { \% }\end{array}$ \\
\hline Весновспашка 15-18 см & 228 & 25,3 \\
\hline $\begin{array}{l}\text { Лущение стерни на } \\
12-14 \text { см }\end{array}$ & 226 & 25,1 \\
\hline $\begin{array}{l}\text { Дискование почвы в 2 } \\
\text { следа на 8-10 см }\end{array}$ & 210 & 23,3 \\
\hline НСР $_{0,5}$ & 5,98 & \\
\hline
\end{tabular}

Учет урожайности в опыте определяли путем таблице 3. Анализ урожайных данных показал, что ловедение лущения стерни достоверно обеспечиМаксимальный показатель достигнут в варианте лущения стерни (66,0 ц/га), минимальный в варианте с Таблица 3. Урожайность риса при разных обработках почвы, 2020 г.

\begin{tabular}{|l|c|}
\hline \multicolumn{1}{|c|}{ Варианты обработок } & Урожайность, ц/га \\
\hline Весновспашка на 15-18 см & 64,4 \\
\hline Лущение стерни на 12-14 см & 66,0 \\
\hline $\begin{array}{l}\text { Дискование почвы в 2 следа } \\
\text { на 8-10 см }\end{array}$ & 62,8 \\
\hline $\mathrm{HCP}_{0,5}$ & 1,22 \\
\hline
\end{tabular}

\section{Выводы}

риса целесообразно использование схем беспрополочной системы, основными элементами которых нозерных форм способы подготовки почвы под посев риса и использование для посева высококачественных семян высших репродукций. Выявлено, что эф-

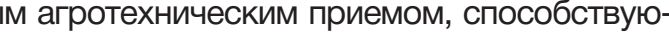
риса, обеспечивающим повышение урожайности и сового сбора, является лущение стерни: снизилась енность посевов на 4,7 \%, зерна - на 4,6 \%, полученного семенного материала на 0,3 \%, что обеспечило увеличение урожайности и валовой сбор риса. 
И.А. Дорошев, С.Ю. Орленко, С.А. Шевель, Н.Н. Малышева, С.А. Тешева и др. / Справочно-методическое издание, Краснодар, 2014. - 120 с.

7. Сметанин, А. П. Методики опытных работ по селекции, семеноводству, семеноведению и контролю за качеством семян риса / А. П. Сметанин, В. А. Дзюба, А. И. Апрод. - Краснодар, 1972. - 156 с.

8. Шеуджен, А.Х. Методика агрохимических исследований и статистическая оценка результатов: учеб. пособие. 2-е изд. перераб и доп. / А,Х. Шеуджен, Т.Н. Бондарева. - Майкоп: ОАО «Полиграф-ЮГ», 2015. - 664 с.

9. Шеуджен, А.Х. Агрохимия. Ч. 2. Методика агрохимических исследований: учебное пособие / А,X. Шеуджен, Т.Н. Бондарева. - Краснодар: КубГАУ, 2018. - 703 с.

10. Ferrero, A. \& Finassi, AViability and soil distribution of red rice (Oriza sativa L. var. sylvatica) seeds. In Med. Fac. Landbouw.,Rigksuniv. Gent. 1995. - P. 205 - 211.

\section{REFERENCES}

1. Aprod, A.I., Kuvarin V.V. Guidelines for the elite rice seeds production / A.I. Aprod, V.V. Kuvarin - M., 1989 .- 28 p.

2. GOST R 52325-2005 "Seeds of agricultural plants. Varietal and sowing qualities. General technical conditions “- M .: Standartinform, 2005. - 24 p.

3. Dospekhov, B.A. Methods of field experiment / B.A. Dospekhov - M .: Kolos, 1985.-351 p.

4. The Law of Krasnodar region "On the regulation of certain relations in the field of seed production on the territory of Krasnodar region” dated November 28, 2014 № 3062-KZ / http://docs.cntd.ru/document/423854860 / date of circulation 12/20/2020).

5. Methodical instructions for the production of elite seeds of grain, leguminous and cereal crops. (reference - methodical edition) // - M .: Kolos, 1982.- 29 p.

6. Methodical recommendations for the cultivation of rice varieties of Kuban breeding / Authors' collective: S.V. Garkusha, I.A. Doroshev, S.Yu. Orlenko, S.A. Shevel, N.N. Malysheva, S.A. Tesheva et al. / Reference and methodological edition, Krasnodar, 2014. - 120 p.

7. Smetanin, A.P. Techniques of experimental work on breeding, seed production, seed studies and quality controlof rice seeds / A.P. Smetanin, V.A. Dzyuba, A.I. Aprod. - Krasnodar, 1972 . - 156 p.

8. Sheudzhen, A.Kh. Agrochemical research methodology and statistical evaluation of their results: textbook, 2nd edition, revised and enlarged / A.Kh. Sheudzhen, T.N. Bondareva Maykop: OJSC Polygraph-YUG, 2015. - 664 p.

9. Sheudzhen, A.Kh. Agrochemistry. Part 2. Technique of agrochemical research: textbook / A. Kh. Sheudzhen, T.N. Bondareva. - Krasnodar: KubSAU, 2018 . - 703 p.

10. Ferrero, A. \& Finassi, AViability and soil distribution of red rice (Oriza sativa L. var. sylvatica) seeds. In Med. Fac. Landbouw.,Rigksuniv. Gent. 1995.- P. 205 - 211.

Гаркуша Сергей Валентинович

Директор ФГБНУ «ФНЦ риса»

E-mail: arrri_kub@mail.ru

\section{Тешева Сусанна Аслановна}

Ведущий научный сотрудник лаборатории семеноводства и семеноведения ФГБНУ «ФНЦ риса», доцент кафедры почвоведения Кубанского ГАУ E-mail: satecheva@mail.ru

\section{Пищенко Дмитрий Александрович}

Заведующий лаборатории семеноводства и семеноведения

E-mail: 89183333172@mail.ru

ФГБНУ «ФНЦ риса»

350091, Россия, г. Краснодар, пос. Белозерный, 3

E-mail: arrri_kub@mail.ru

ФГБОУ ВО «Кубанский государственный аграрный университет имени И. Т. Трубилина» 350044, Россия, г. Краснодар, ул. Калинина, 13

\section{Sergey Valentinovich Garkusha}

Direktor FSBSI Federal Scientific Rice Centre

E-mail: arrri_kub@mail.ru

\section{Tesheva Susanna Aslanovna}

Leading researcher of the laboratory of seed production ,and seed science FSBSI Federal Scientific Rice Centre, associate professor of the department of soil science, Kuban State Agrarian University

E-mail: satecheva@mail.ru

\section{Pischenko Dmitry Aleksandrovich}

Head of the laboratory laboratory of seed production and seed science

E-mail: 89183333172@mail.ru

FSBSI Federal Scientific Rice Centre

3, Belozerniy, Krasnodar, 350921, Russia

E-mail: arrri_kub@mail.ru

Federal State Budgetary Education Institution of Higher Education «Kuban State Agrarian University named after I.T. Trubilin

13 Kalinina st., Krasnodar, 350044, Russia 


\section{СОЗДАНИЕ РАННЕСПЕЛЫХ И СРЕДНЕРАННИХ ГИБРИДОВ КУКУРУЗЫ С УЧАСТИЕМ НОВЫХ АВТОДИПЛОИДНЫХ ЛИНИЙ В УСЛОВИЯХ ЦЕНТРАЛЬНОЙ ЗОНЫ КРАСНОДАРСКОГО КРАЯ}

Потребность в новых высокопродуктивных гибридах кукурузы растет с каждым годом. Кукурузное зерно - важный компонент многих отраслей производства. В настоящее время особой актуальностью отличается работа по созданию и оценке нового исходного материала, которая занимает важное положение в селекционной работе. Получение качественного инбредного материала - важное звено в селекции на гетерозис. В данной статье рассмотрены результаты испытания гибридов кукурузы, созданных с участием новых раннеспелых и среднеранних автодиплоидных линий. Использование линий данных групп спелости позволяет расширить ареал использования новых гибридов, продвигаясь в зоны, для которых длина вегетационного периода имеет критическое значение. В работе рассмотрены такие основные понятия, как урожайность зерна, уборочная влажность и погодные условия за три года проведения исследований. Целью нашей работы было создание и оценка гибридных комбинаций с участием новых раннеспелых и среднеранних автодиплоидных линий кукурузы. Для создания нового исходного материала использовались 6 линий из генетической коллекции Национального Центра Зерна

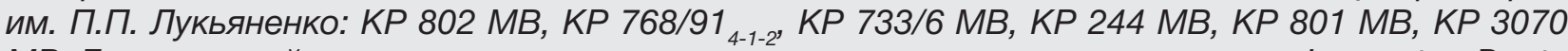
MB. Генетический материал принадлежал различным гетерозисным группам - Lancaster, Dento Rio Gradense Rigoso, Stiff Stalk Synthetic. На данном генетическом материале был заложен опыт по созданию новых линий кукурузы с применением метода ускоренного получения гаплоидов кукурузы, разработанным сотрудниками НЦЗ. В результате работы был выделен новый линейный материал и разбит на два блока по группам спелости - раннеспелые и среднеранние. $K$ каждому блоку линий было подобрано по три тестера КP 742 M, KP 714 M и KP 742 х 770 для раннеспелых линий и КР $640602_{18-1-1}$ х КP $757602_{4-1-2}$, KP 640 M x 651 и KP 640 M х KP $757602_{4-1-2}$ для среднеранних линий.

Ключевые слова: гибриды, урожайность, влажность, климатические условия, гаплоидия.

\section{CREATION OF EARLY MATURING AND MID-EARLY MAIZE HYBRIDS WITH THE PARTICIPATION OF NEW AUTODIPLOID LINES IN THE CENTRAL ZONE OF KRASNODAR TERRITORY}

For a long time, the need for new highly productive corn hybrids has been growing every year. Corn is an important component of many industries. Currently, work on the creation and assessment of new source material, which occupies an important position in breeding work, is of particular relevance. The productivity of new corn hybrids depends on the quality of the starting material. This article discusses the results of testing maize hybrids created with the participation of new early-maturing and mid-early autodiploid lines. The use of lines of these groups of ripeness makes it possible to expand the area of use of new hybrids, moving into zones for which the length of the growing season is of critical importance. The paper considers such basic concepts as grain yield, harvesting humidity and weather conditions for three years of research. The aim of our work was to create and evaluate hybrid combinations with the participation of new early maturing and mid-early autodiploid lines of maize. To create a new source material, 6 lines from the genetic collection of the National Center for Grain named after P.P. Lukyanenko: KR 802 MV, KR 768 / 91 ${ }_{4-1-2}$ KR 733/6 MV, KR 244 MV, KR 801 MV, KR 3070 MV. This genetic material belonged to various heterotic groups - Lancaster, Dento Rio Gradense Rigoso, Stiff Stalk Synthetic. This genetic material was used to create experience in the creation of new lines of maize using the method of accelerated production of maize haploids, developed by the staff of the $S C C$. As a result of the work, a new linear material was identified and divided into two blocks according to ripeness groups - early maturing and mid-early. Three testers $K R 742 M, K R 714 M$ and KR $742 x$ 770 for early maturing lines and KR $640602_{18-1-1}$ x KR $757602_{4-1-2,}$ KR $640 M \times 651$ and $K R 640 M \times K P$ $757602_{4-1-2}$ for mid-early lines were selected for each block of lines.

Key words: hybrids, productivity, humidity, climatic conditions, haploidy. 


\section{Введение}

Продовольственная безопасность - важная составляющая каждой страны. В Российской Федерации кукуруза как зерновая и силосная культура, занимает важное положение в сельском хозяйстве. Площади возделывания гибридов кукурузы на зерно с 1030 тыс. га в 2007 г. увеличилась до 2450 тыс. га в 2013 г, а в 2016 уже превышали 2887 тыс. га. Увеличение объёмов рынка происходит благодаря высокому спросу внутри страны. В последние годы также значительно увеличился показатель урожайности данной культуры, был достигнут наивысший валовой сбор зерна за всю отечественную историю. На данный момент кукуруза по площадям посева идёт после таких культур как пшеница и ячмень [2, 5].

Основная задача селекции кукурузы в настоящее время - создание высокопродуктивных гибридов с хорошей отдачей влаги зерном при созревании. Успешность данного направления зависит от использования качественного исходного материала, несущего в генотипе полезные признаки и в задачи селекционера, входит поиск наиболее удачных родительских комбинаций для достижения данных целей [4].

В последнее время наблюдается увеличение площадей посевов раннеспелых гибридов в зонах, где короткий вегетационный период играет важную роль. Среднеранние гибриды с успехом возделываются в климатических условиях Южного федерального округа. Продвижение в данные зоны ставит перед селекционерами страны большие задачи по внедрению в производство новых высокопродуктивных гибридов кукурузы, отличающихся высокой урожайностью и низкой уборочной влажностью. Поэтому в настоящее время создание нового исходного материала для селекции раннеспелых и среднеранних гибридов кукурузы является весьма актуальной задачей.

Существует два основных способа создания такого исходного материала - получение самоопылённых линий и создание нового исходного материала методом гаплоидии. Преимущество последнего достигается за счёт значительного уменьшения времени для получения инбредной линии. В среднем для получения самоопылённой инбредной линии требуется 6 - 7 полевых сезонов, тогда как использование метода гаплоидии позволяет получать новые инбредные линии за 1 - 2 полевых сезона [3].

Использование растений - гаплоиндукторов позволяет ускорить процесс создания автодиплоидных линий кукурузы. Возникновение гаплоидов происходит в результате развития зародыша с одинарным набором хромосом (Zeamays L., $n=10$ ) из неоплодотворенной яйцеклетки. Образование гаплоидов находится под генетическим контролем родительских форм растений кукурузы. Растение - гаплоиндуктор представляет собой высокофертильную линию, в результате гибридизации с которой образуются зер- новки с гаплоидным числом хромосом в зародыше. В настоящее время при использовании современных гаплоиндукторов удалось добиться высокой частоты получения гаплоидных зерновок 10-15 \% на 1000 проанализированных образцов $[1,6]$.

Основные требования, предъявляемые к гаплоиндукторам - это содержание в своём генотипе доминантных аллелей, которые хорошо визуализируются на зерновках, а материнские растения должны нести рецессивные аллели того же гена окраски зерновки. Это позволит более эффективно выбраковывать зерновки с доминантными проявлениями признаков - диплоидные, а отбирать только те, которые характеризовались проявлениями рецессивных аллелей - гаплоидные зерновки [8, 9, 10, 11].

\section{Цель исследований}

Изучить зерновую продуктивность гибридов кукурузы, созданных с использованием новых раннеспелых и среднеранних автодиплоидных линий за три года проведения исследований в контрольном питомнике НЦЗ им. П.П. Лукьяненко.

\section{Материалы и методы}

Работа по созданию и изучению нового исходного материала и гибридов кукурузы проходила на опытных полях Национального центра зерна им. П.П. Лукьяненко в 2017-2020 годах. Опыты проводились в условиях богарного земледелия. Для создания нового исходного материала нами были взяты 6 линий из генетической коллекции НЦЗ: КР 802 МВ, KP 768/91 KP 3070 МВ. Данный генетический материал принадлежал различным гетерозисным группам - Lancaster, Dento Rio Gradense Rigoso, Stiff Stalk Synthetic. B дальнейшем с целью создания нового исходного материала нами было создано 5 гибридных комбинаций с участием данных линий: КР 244 МВ x КР 802 MB, КР 733/6 MB x KP 802 MB, KP 244 MB x KP 768/91 ${ }_{4-1-2}$, KP 3070 MB x KP 802 MB и KP 801 MB x KP 733/6 MB [3]. Далее на полученных гибридных комбинациях была начата работа по получению новых автодиплоидных линий по методу, разработанному сотрудником НЦЗ им. П.П. Лукьяненко Шацкой Ольгой Александровной с соавторами $[6,7]$. Впоследствии по биолого-морфлогическим признакам было отобрано 28 раннеспелых и 23 среднеранние линии кукурузы. Далее к новому линейному материалу, к каждому блоку было подобрано по три тестера: КР 742 М, КР 714 М и КР 742 x 770 для раннеспелых линий и КР 640602 ${ }_{1-1}$ x KP $757602_{4-1-2}$, КР 640 M x 651 для среднеранних линий. Тестеры относились к гетерозисной группе Ident. Впоследствии полученный гибридный материал был высеян в контрольном питомнике в 3-х кратной повторности, норма высева составляла 72 зерна на делянку площадью 9,8 м².

Одним из ключевых факторов при выращивании кукурузы являются погодные условия. Климатические условия 2018-2020 годов проведения исследований кардинально различались. С данными 
по климатическим условиям, сложившимся в центральной зоне Краснодарского края можно ознакомиться на рисунках 1, 2 и 3.

Условия 2018 года были весьма негативными. Количество выпавших осадков было значительно ниже среднемноголетнего показателя, в сочетании с высокими дневными температурами данные условия негативно сказались на росте и развитие испытуемых гибридов кукурузы. Данные погодных условий представлены на рисунке 1.

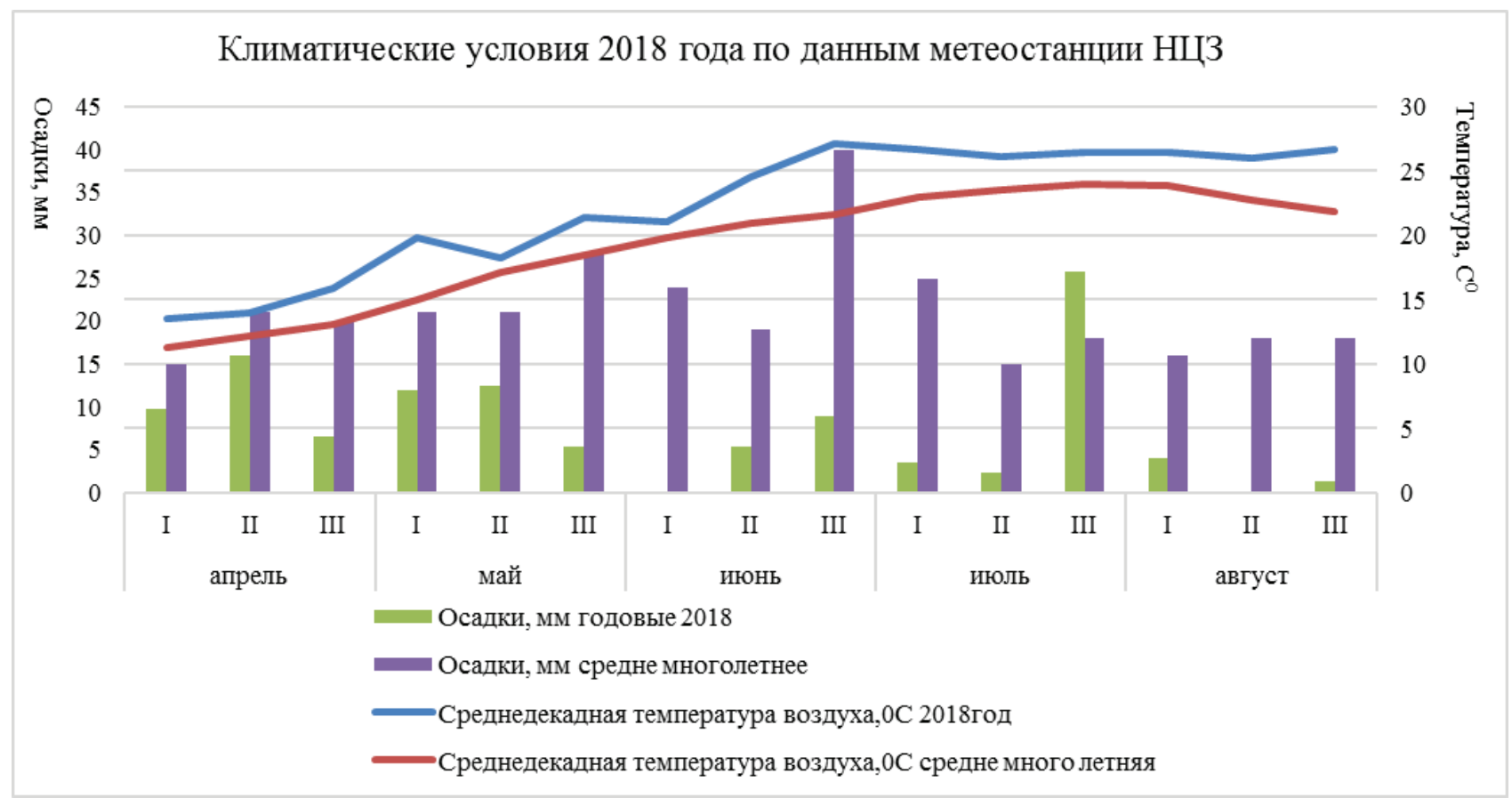

Рисунок 1. Климатические условия 2018 года по данным метеостанции НЦЗ

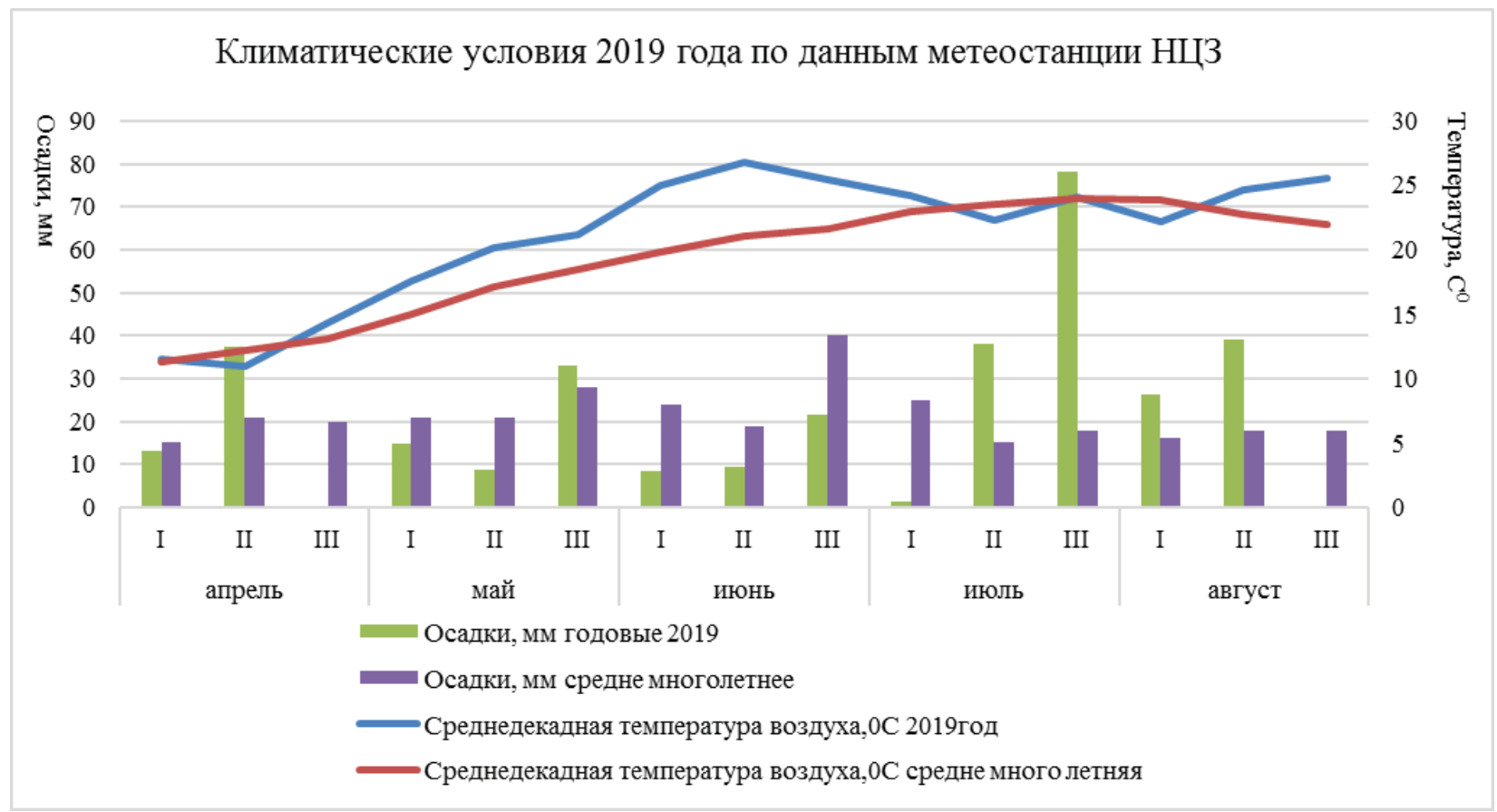

Рисунок 2. Климатические условия 2019 года по данным метеостанции НЦЗ

Климатические условия 2019 года исследований можно назвать условно благоприятными. Количество выпавших осадков в важные периоды вегетации позволило новым гибридам сформировать хороший показатель урожайности, несмотря на высокие дневные температуры. Данные погодных условий представлены на рисунке 2.

Климатические условия 2020 года оказались достаточно спорными. Среднедекадная температура воздуха превышала среднемноголетний показатель. Одна- 
ко, количество выпавших осадков в важные периоды вегетации позволило сформировать показатель уро- жайности новых гибридов на уровне 50 ц с га. Данные погодных условий представлены на рисунке 3.

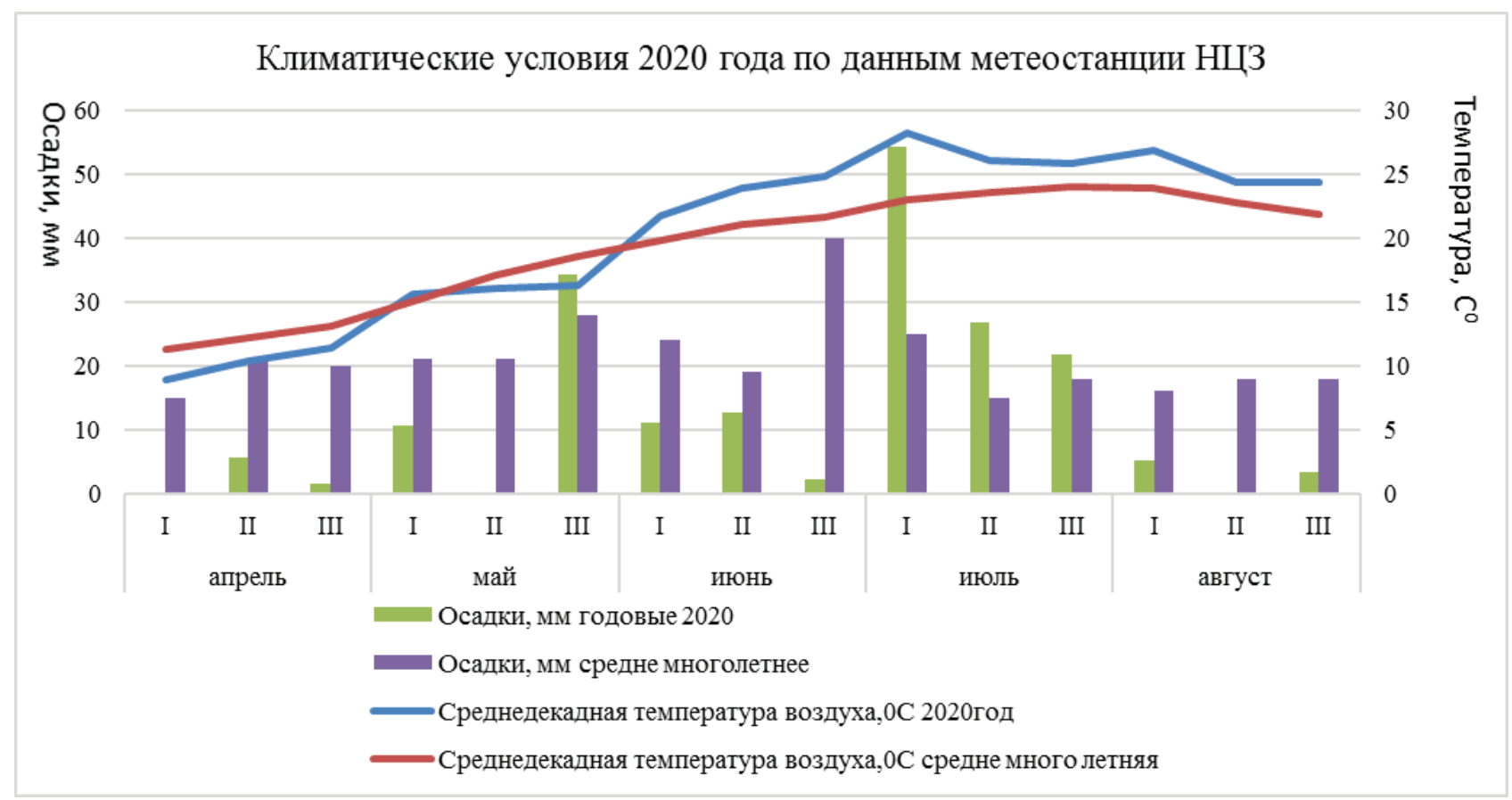

Рисунок 3. Климатические условия 2020 года по данным метеостанции НЦЗ

\section{Результаты и обсуждение}

Как видно из рисунка 1, в третьей декаде мая периоде формирования генеративных органов высокая дневная температура и отсутствие необходимого количества осадков сыграли негативную роль в развитии растений. Другой важный вегетационный период роста и развития растений кукурузы - вторая и третья декады июня - это этапы цветения раннеспелого и среднераннего материа- ла исследований. Высокие дневные температуры и малое количество осадков негативно сказались на зерновой продуктивности изучаемых гибридов.

Однако, несмотря на неблагоприятные погодные условия, по результатам исследования были получены новые гибридные комбинации кукурузы, достоверно превысившие по урожайности зерна используемый стандарт. Данные гибридные комбинации представлены в таблице 1.

Таблица 1. Результаты испытания раннеспелых гибридов кукурузы в контрольном питомнике, Краснодар 2018 г

\begin{tabular}{|c|c|c|c|}
\hline Название гибрида & $\begin{array}{l}\text { Урожайность } \\
\text { зерна, ц с } 1 \text { га }\end{array}$ & $\begin{array}{c}\text { Отклонение от } \\
\text { стандарта, ц с } 1 \text { га }\end{array}$ & $\begin{array}{c}\text { Уборочная влажность } \\
\text { зерна, \% }\end{array}$ \\
\hline Краснодарский 194 MB (st) & 18,06 & - & 20,83 \\
\hline $1525_{/ 86} \times(742 \times 770)$ & 30,67 & 12,61 & 19,60 \\
\hline $1524_{/ 17} \times(742 \times 770)$ & 28,84 & 10,78 & 21,57 \\
\hline $1524_{/ 17} \times 742$ & 28,51 & 10,45 & 24,57 \\
\hline $1524_{/ 7} \times 742$ & 28,43 & 10,37 & 18,17 \\
\hline $1527_{/ 1} \times 742$ & 27,95 & 9,89 & 21,37 \\
\hline $1524_{/ 8} \times 742$ & 26,36 & 8,30 & 23,37 \\
\hline $1525_{/ 20} \times(742 \times 770)$ & 26,16 & 8,10 & 18,47 \\
\hline $1525_{/ 32} \times(742 \times 770)$ & 26,12 & 8,06 & 19,70 \\
\hline $1525_{/ 20} \times 742$ & 25,69 & 7,63 & 19,30 \\
\hline $1525_{/ 86} \times 742$ & 24,69 & 6,63 & 19,93 \\
\hline $1525_{/ 89} \times(742 \times 770)$ & 23,79 & 5,73 & 18,67 \\
\hline $1525_{/ 32} \times 742$ & 23,73 & 5,67 & 20,83 \\
\hline $\mathrm{HCP}_{05}$ & \multicolumn{3}{|c|}{3,01} \\
\hline
\end{tabular}


Как видно из таблицы, превышение по показателю «урожайность зерна» к уровню стандарта составило от 5,67 до 12,61 ц с га. Уборочная влажность новых гибридов кукурузы колебалась от $18 \%$ до $23 \%$.

Из блока среднеранних гибридов кукурузы выделились следующие гибридные комбинации, представленные в таблице 2.

Таблица 2. Результаты испытания среднеранних гибридов кукурузы в контрольном питомнике, Краснодар 2018 г

\begin{tabular}{|l|c|c|c|}
\hline \multicolumn{1}{|c|}{ Название гибрида } & $\begin{array}{c}\text { Урожайность } \\
\text { зерна, ц с 1 га }\end{array}$ & $\begin{array}{c}\text { Отклонение от } \\
\text { стандарта, ц с 1 га }\end{array}$ & $\begin{array}{c}\text { Уборочная влажность } \\
\text { зерна, \% }\end{array}$ \\
\hline Краснодарский 291 АМВ (st) & 26,58 & - & 26,67 \\
\hline $1524_{/ 6} \times(640 \times 651)$ & 36,90 & 10,32 & 25,40 \\
\hline $1525_{/ 28} \times(640602 \times 757602)$ & 33,19 & 6,61 & 22,33 \\
\hline $1525_{/ 2} \times(640602 \times 757602)$ & 32,47 & 5,89 & 15,87 \\
\hline $1528_{/ 5} \times(640602 \times 757602)$ & 32,26 & 5,68 & 25,60 \\
\hline $1524_{/ 36} \times(640 \times 651)$ & 32,15 & 5,57 & 25,23 \\
\hline $1526_{/ 3} \times(640 \times 757602)$ & 31,31 & 4,73 & 19,17 \\
\hline $1528_{/ 5} \times(640 \times 757602)$ & 31,14 & 4,56 & \\
\hline $\mathrm{HCP}_{05}$ & 3,74 & & \\
\hline
\end{tabular}

Из таблицы 2 видно, что достоверная прибавка в урожайности у лучших гибридов составила от 4,56 до 10,32 ц с га. Уборочная влажность зерна новых гибридов была на уровне используемого стандарта. Однако, некоторые гибридные комбинации с участием линии 1528 , показали более низкую уборочную влажность - 15,87 и 19,17 \%.

В дальнейшем аналогичные исследования про- водились в 2019 опытном году. Погодные условия 2019 года можно охарактеризовать как условно благоприятные относительно 2018 года проведения исследований. По результатам исследования 2019 года в контрольном питомнике из блока раннеспелых и среднеранних гибридов кукурузы выделились следующие гибридные комбинации, результаты представлены в таблицах 3 и 4.

Таблица 3. Результаты испытания раннеспелых гибридов кукурузы в контрольном питомнике, Краснодар 2019 г

\begin{tabular}{|l|c|c|c|}
\hline \multicolumn{1}{|c|}{ Название гибрида } & $\begin{array}{c}\text { Урожайность } \\
\text { зерна, ц с 1 га }\end{array}$ & $\begin{array}{c}\text { Отклонение от } \\
\text { стандарта, ц с 1 га }\end{array}$ & $\begin{array}{c}\text { Уборочная влажность } \\
\text { зерна, \% }\end{array}$ \\
\hline Краснодарский 194 MB (st) & 56,85 & - & 18,70 \\
\hline $1525_{/ 79} \times(742 \mathrm{M} \times 770)$ & 75,44 & 18,59 & 20,47 \\
\hline $1525_{/ 32} \times(742 \mathrm{M} \times 770)$ & 67,86 & 11,01 & 14,47 \\
\hline $1525_{/ 80} \times(742 \mathrm{M} \times 770)$ & 67,20 & 10,35 & 17,97 \\
\hline $1525_{/ 10} \times 714$ зак M & 66,22 & 9,37 & 15,37 \\
\hline $1525_{/ 81} \times(742 \mathrm{M} \times 770)$ & 65,31 & 8,46 & 17,70 \\
\hline $1525_{/ 15} \times(742 \mathrm{M} \times 770)$ & 63,60 & 6,75 & \\
\hline $\mathrm{HCP}_{05}$ & 4,67 & \\
\hline
\end{tabular}

Как видно из таблицы 3, превышение по показателю урожайность зерна к уровню стандарта составила от 6,75 до 18,59 ц с га. Уборочная влажность новых гибридов кукурузы была на уровне или ниже используемого стандарта. Однако, отдельно хочется выделить две гибридные комбинации с участием новых автодиплоидных линий как $1525_{/ 32}$ и 1525/81. Уборочная влажность данных гибридных комбинаций была значительно ниже используемого стандарта и составляла $14,47 \%$ и $15,37 \%$.

Из блока среднеранних гибридов кукурузы выделились следующие гибридные комбинации, представленные в таблице 4.
Из таблицы 4 видно, что достоверная прибавка урожайности составила от 9,51 до 16,41 ц с га. Уборочная влажность была на уровне или ниже используемого стандарта.

Следующим этапом работы была оценка новых раннеспелых и среднеранних гибридов кукурузы в 2020 опытном году. Как видно из рисунка 3, климатические условия 2020 года оказались весьма спорными. Однако, несмотря на данные погодные условия, по результатам исследования 2020 года в контрольном питомнике из блока раннеспелых и среднеранних гибридов кукурузы выделились следующие гибридные комбинации, результаты представлены в таблицах 5 и 6. 
Таблица 4. Результаты испытания среднеранних гибридов кукурузы в контрольном питомнике, Краснодар 2019 г

\begin{tabular}{|c|c|c|c|}
\hline Название гибрида & $\begin{array}{l}\text { Урожайность } \\
\text { зерна, ц с } 1 \text { га }\end{array}$ & $\begin{array}{c}\text { Отклонение от } \\
\text { стандарта, ц с } 1 \text { га }\end{array}$ & $\begin{array}{c}\text { Уборочная влажность } \\
\text { зерна, \% }\end{array}$ \\
\hline Краснодарский 291 AMB (st) & 63,01 & - & 17,93 \\
\hline $1525_{/ 69} \times(640 \mathrm{M} \times 757602)$ & 79,42 & 16,41 & 17,93 \\
\hline $1526_{/ 3} \times(640602 \times 757602)$ & 75,70 & 12,69 & 14,97 \\
\hline $1528_{/ 28} \times(640 \times 651)$ & 74,99 & 11,98 & 17,10 \\
\hline $1524_{/ 6} \times(640 \times 757602)$ & 73,77 & 10,76 & 16,07 \\
\hline $1525_{/ 86} \times(640602 \times 757602)$ & 73,57 & 10,56 & 14,77 \\
\hline $1528_{/ 28} \times(640 \times 757602)$ & 73,47 & 10,46 & 18,50 \\
\hline $1525_{/ 36} \times(640 \times 757602)$ & 73,44 & 10,43 & 17,87 \\
\hline $1528_{/ 13} \times(640 \times 651)$ & 73,18 & 10,17 & 18,03 \\
\hline $1524_{/ 3} \times(640 \times 757602)$ & 72,52 & 9,51 & 17,90 \\
\hline $\mathrm{HCP}_{05}$ & 4,59 & & \\
\hline
\end{tabular}

Таблица 5. Результаты испытания раннеспелых гибридов кукурузы в контрольном питомнике, Краснодар 2020 г.

\begin{tabular}{|l|c|c|c|}
\hline \multicolumn{1}{|c|}{ Название гибрида } & $\begin{array}{c}\text { Урожайность } \\
\text { зерна, ц с 1 га }\end{array}$ & $\begin{array}{c}\text { Отклонение от } \\
\text { стандарта, ц с 1 га }\end{array}$ & $\begin{array}{c}\text { Уборочная влажность } \\
\text { зерна, \% }\end{array}$ \\
\hline Краснодарский 194 MB (st) & 43,48 & - & 15,90 \\
\hline $1526_{/ 1} \times(742 \times 770)$ & 53,82 & 10,34 & 19,33 \\
\hline $1525_{/ 86} \times 742$ 3M & 52,38 & 8,90 & 20,70 \\
\hline $1525_{/ 80} \times 7423 \mathrm{M}$ & 50,89 & 7,41 & 14,73 \\
\hline $1525_{/ 32} \times 7423 \mathrm{M}$ & 50,11 & 6,63 & \\
\hline $\mathrm{HCP}_{05}$ & \multicolumn{2}{|c|}{6,32} \\
\hline
\end{tabular}

Как видно из таблицы достоверная прибавка в урожайности составила от 6,63 до 10,34 ц с га. Гибридная комбинация с участием линии $1525_{132}$ показала наименьший результат по величине убо- рочной влажности относительно используемого стандарта. Остальные гибридные комбинации отличались более высоким показателем уборочной влажности зерна.

Таблица 6. Результаты испытания среднеранних гибридов кукурузы в контрольном питомнике, Краснодар 2020 г

\begin{tabular}{|l|c|c|c|}
\hline \multicolumn{1}{|c|}{ Название гибрида } & $\begin{array}{c}\text { Урожайность } \\
\text { зерна, ц с 1 га }\end{array}$ & $\begin{array}{c}\text { Отклонение от } \\
\text { стандарта, ц с 1 га }\end{array}$ & $\begin{array}{c}\text { Уборочная } \\
\text { влажность зерна, \% }\end{array}$ \\
\hline $\mathrm{Kраснодарский} \mathrm{291} \mathrm{АМВ} \mathrm{(st)}$ & 49,35 & - & 25,07 \\
\hline $1528_{/ 5} \times(640602 \times 757602)$ & 57,78 & 8,43 & 13,43 \\
\hline $1525_{/ 36} \times(640 \times 757602)$ & 52,94 & 3,59 & 16,60 \\
\hline $1528_{/ 6} \times(640 \times 651)$ & 49,70 & 0,35 & 18,03 \\
\hline $\mathrm{HCP}_{05}$ & 6,21 & \multicolumn{3}{|l}{} \\
\hline
\end{tabular}

Как видно из таблицы 6 достоверное превышение урожайности относительно используемого стандарта было только у одной гибридной комбинации с участием линии $1528_{/ 5}$. Прибавка составила 8,43 ц с га при более низкой уборочной влажности. Гибридные комбинации с участием линий $1525_{/ 36}$ и 1528, показали результаты урожайности на уровне используемого стандарта, но достоверно его не превысили. Уборочная влажность данных гибридов была ниже используемого стандарта.

\section{Выводы}

Таким образом, нами была проведена оценка результатов по урожайности и уборочной влажности раннеспелых и среднеранних гибридов кукурузы с участием новых автодиплоидных линий за три года исследования в контрольном питомнике. В 2018 году прибавка в урожайности составила от 5,67 до 12,61 ц с га в блоке раннеспелых гибридов кукурузы. В блоке среднеранних прибавка в урожайности составила 4,56 до 10,32 ц с га. В 2019 
опытном году в блоке раннеспелых гибридов - от 6,75 до 18,59 ц с га. В блоке среднеранних гибридов - от 9,51 до 16,41 ц с га. В 2020 опытном году в блоке раннеспелых гибридов кукурузы - от 6,63 до 10,34 ц с га. В блоке среднеранних гибридов только одна гибридная комбинация достоверно превысила показатель урожайности стандарта на 8,43 ц с га.

\section{ЛИТЕРАТУРА}

1. Асадова, Г.М. Перспективы использования гаплоиндукторов в селекции кукурузы / Г.М Асадова, А.В. Ульянова, М.В. Карлов, Э.Б. Хатефов // Биотехнология и селекция растений. - Санкт-Петербург, 2020. - № 2(3). C. $16-29$.

2. Луковкина, Н.И. Создание новых линий для селекции ультрараннеспелых и раннеспелых гибридов кукурузы / Н.И Луковкина, Н.П. Соболева, А.И Супрунов // Сборник статей XI Всероссийская конференция молодых ученыХ, посвященная 95-летию Кубанского ГАУ и 80-летию со дня образования Краснодарского края. - Краснодар, 2017. C. $1283-1284$.

3. Перевязка, Д.С. Создание новых раннеспелых и среднеранних гибридов кукурузы с участием новых автодиплоидных линий / Д.С. Перевязка, А.И. Супрунов // Материалы международной научно-практической конференции, посвященной 110-й годовщине со дня рождения П.Е. Ладана «Аспекты животноводства и производства продуктов питания». - Персиановский, 2018. - С. 337 - 342.

4. Сотченко, В.С. Перспективы производства зерна и семян кукурузы в Российской Федерации на период до 2020 года / В.С. Сотченко // Кукуруза и сорго. - Пятигорск, 2010. - № 4. - С. 3 - 11.

5. Сотченко, В.С. Роль кукурузы в повышении продовольственной независимости страны / В.С. Сотченко // Вестник российской академии наук. - Москва, 2015. - № 1 (85). - С. 12 - 14.

6. Шацкая, О.А. Создание гаплоиндукторов кукурузы: три цикла отбора на высокую частоту индукции матроклинных гаплоидов / О.А. Шацкая // Сельскохозяйственная биология. - Москва, 2010. - № 5. - С. 79 - 86.

7. Шацкая, О.А. Результаты использования метода гаплоидии в селекции кукурузы / О.А. Шацкая // Кукуруза и сорго. - Пятигорск, 2001. - № 4. - С. 14 - 17.

8. Chase, S.S. Monoploids and monopoid derivatives of maize (Zea mays L.) / Chase S.S. // Botanical Review. 1969. - V. 35. - № 2. - P. 117 - 168.

9. Chase, S.S. Selection for parthenogenesis and monoploid fertility in maize. / Chase S.S. // Genetics. - 1952 . - № 37. - P. $573-574$.

10. Kebede, A.Z. Effect of source germplasm and season on the in vivo haploid induction rate in tropical maize / Kebede A.Z., Dhillon B.S., Schipprack W., Araus J.L., Banziger M., Semagan K., Alvarado G., Melchinger A.E. // Euphytica. - 2011. - № 180(2). - P. 219 - 226.

11. Prigge, V. Doubled haploids in tropical maize: I. Effects of inducers and source germplasm on in vivo haploid induction rates / Prigge V., Sanchez C., Dhillon B.S., Schipprack W., Araus J.L, Banziger M., Melchinger A.E. // Crop Science. - 2011. - № 51. - P. 1498 - 1506.

\section{REFERENCES}

1. Asadova, G.M. Prospects for the use of haploinductors in corn breeding / G.M. Asadova, A.V. Ulyanova, M.V. Karlov, E.B. Hatefov // Biotechnology and plant breeding. - St. Petersburg, 2020. - № 2 (3). - P. 16 - 29.

2. Lukovkina, N.I. Creation of new lines for the selection of ultra-early and early-maturing corn hybrids / N.I. Lukovkina, N.P. Soboleva, A.I Suprunov // Collection of articles of the XI All-Russian conference of young scientists dedicated to the 95th anniversary of the Kuban State Agrarian University and the 80th anniversary of the founding of the Krasnodar Territory. - Krasnodar, 2017. - P. 1283 - 1284.

3. Perevyazka, D.S. Creation of new early-maturing and mid-early maize hybrids with the participation of new autodiploid lines / D.S. Perevyazka, A.I. Suprunov // Materials of the international scientific-practical conference dedicated to the 110th anniversary of the birth of P.E. Ladana "Aspects of Livestock and Food Production". - Persianovsky, 2018. - P. 337 $-342$.

4. Sotchenko, V.S. Prospects for the production of grain and corn seeds in the Russian Federation for the period until 2020 / V.S. Sotchenko // Corn and sorghum. - Pyatigorsk, 2010. - № 4. - P. 3 - 11.

5. Sotchenko, V.S. The role of corn in increasing food independence of the country / V.S. Sotchenko // Bulletin of the Russian Academy of Sciences. - Moscow, 2015. - № 1 (85). - P. 12 - 14.

6. Shatskaya, O. A. Creation of maize haploinducers: three selection cycles for a high frequency of induction of matroclinous haploids / O.A. Shatskaya // Agricultural biology. - Moscow, 2010. - № 5. - P. 79 - 86.

7. Shatskaya, O. A. Results of using the haploidy method in corn breeding / O.A. Shatskaya // Corn and sorghum. - Pyatigorsk, 2001. - № 4. - P. 14 - 17.

8. Chase, S.S. Monoploids and monopoid derivatives of maize (Zea mays L.) / Chase S.S. // Botanical Review. 1969. - V. 35. - № 2. - P. 117 - 168.

9. Chase, S.S. Selection for parthenogenesis and monoploid fertility in maize. / Chase S.S. // Genetics. -1952. - № 37. - P. $573-574$.

10. Kebede, A.Z. Effect of source germplasm and season on the in vivo haploid induction rate in tropical maize / Kebede A.Z., Dhillon B.S., Schipprack W., Araus J.L., Banziger M., Semagan K., Alvarado G., Melchinger A.E. // Euphytica. - 2011. - № 180(2). - P. 219 - 226. 
11. Prigge, V. Doubled haploids in tropical maize: I. Effects of inducers and source germplasm on in vivo haploid induction rates / Prigge V., Sanchez C., Dhillon B.S., Schipprack W., Araus J.L, Banziger M., Melchinger A.E. // Crop Science. - 2011. - № 51. - P. 1498 - 1506.

\section{Перевязка Дмитрий Сергеевич}

Младший научный сотрудник отдела селекции

и семеноводства кукурузы

E-mail: dmitriy_perevyazka@mail.ru

Тел. +79286645814

\section{Перевязка Наталья Игоревна}

Младший научный сотрудник отдела селекции и семеноводства кукурузы

\section{Супрунов Анатолий Иванович}

Заведующий отделом селекции и семеноводства кукурузы

Bсе: ФГБНУ «НЦЗ им. П.П. Лукьяненко» г. Краснодар, Центральная Усадьба КНИИСХ

\section{Perevyazka Dmitry Sergeevich}

Junior researcher of the department of selection and seed production of corn

E-mail: dmitriy_perevyazka@mail.ru

Phone. +79286645814

\section{Perevyazka Natalia Igorevna}

Junior researcher of the department of selection and seed production of corn

\section{Suprunov Anatoly Ivanovich}

head of the department of selection and seed production of corn

ALL: FSBSI «NCG named P.P. Lukyanenko» Krasnodar, Central Estate KNIISH 


\section{ИЗУЧЕНИЕ ОБЩЕЙ КОМБИНАЦИОННОЙ СПОСОБНОСТИ НОВЫХ РАННЕСПЕЛЫХ И СРЕДНЕРАННИХ АВТОДИПЛОИДНЫХ ЛИНИЙ КУКУРУЗЫ В УСЛОВИЯХ ЦЕНТРАЛЬНОЙ ЗОНЫ КРАСНОДАРСКОГО КРАЯ}

Площади посевов кукурузы на зерно увеличиваются ежегодно и вопрос качественного исходного материала для создания новых гибридов остаётся открытым. Данная культура отличается широтой своего применения в жизнедеятельности человека. Кукуруза характеризуется, как отличная кормовая культура для сельскохозяйственных животных. Крахмал, получаемый из зерна, находит применение в химической и фармацевтической промышленности. Наиболее важно понимать, как различные генотипы растений будут взаимодействовать между собой в скрещиваниях. Для изучения взаимодействия различных генотипов между собой используется методика определения общей комбинационной способности новых линий кукурузы. Применение данной методики позволяет выделять наиболее хорошо комбинирующие генотипы растений. В Национальном центре зерна им. П.П. Лукьяненко ежегодно проводится оценка большого количества линейного материала по методам общей и специфической комбинационной способности. Целью нашей работы была оценка общей комбинационной способности новых раннеспелых и среднеранних автодиплоидных линий кукурузы, созданных из шести линий генетической коллекции Национального центра зерна им. П.П. Лукьяненко: КР 802 MВ, KP 768/91 4-1-2, КР 733/6 MB, KP 244 MB, KP 801 MB, KР 3070 МВ. По результатам работы выделенные линии разбили на два блока по группам спелости: раннеспелые и среднеранние автодиплоидные линии кукурузы. Результаты представлены за три года проведения исследований. Были выделены новые раннеспелые и среднеранние линии кукурузы, отличающиеся высокой общей комбинационной способностью. Были рассмотрены погодные условия за три года проведения исследований и их влияние на значения общей комбинационной способности.

Ключевые слова: погодные условия, гибриды, генотип, урожайность зерна, комбинационная способность.

\section{STUDY OF THE GENERAL COMBINING ABILITY OF NEW EARLY MATURING AND MID-EARLY AUTODIPLOID LINES OF MAIZE IN THE CENTRAL ZONE OF KRASNODAR TERRITORY}

The area under corn for grain is increasing annually and the question of high-quality source material for creating new hybrids remains open. This culture is distinguished by the breadth of its application in human life. Corn is characterized as an excellent forage crop for farm animals. The starch obtained from grain is used in the chemical and pharmaceutical industries. It is most important to understand how different plant genotypes will interact with each other in crosses. To study the interaction of different genotypes with each other, a technique is used to determine the overall combinational ability of new maize lines. The use of this technique makes it possible to isolate the most well-combining plant genotypes. At the National Grain Center named after P.P. Lukyanenko annually evaluates a large amount of linear material by the methods of general and specific combining ability. The aim of our work was to assess the overall combinational ability of new early-maturing and mid-early autodiploid lines of maize, created from six lines of the genetic collection of the National Grain Center named after P.P. Lukyanenko: KR 802 MV, KR 768 / 91 ${ }_{4-1-2,}$ KR 733/6 MV, KR 244 MV, KR 801 MV, KR 3070 MV. According to the results of the work, the selected lines were divided into two blocks according to ripeness groups - early maturing and mid-early autodiploid lines of maize. The results are presented for three years of research. New early maturing and mid-early lines of maize were identified, which are distinguished by a high general combinational ability. Were considered weather conditions for three years of research and their impact on the values of the general combining ability.

Key words: weather conditions, hybrids, genotype, grain yield, combining ability. 


\section{Введение}

В настоящее время селекция раннеспелых и среднеранних гибридов кукурузы отличается особой актуальностью в связи с тем, что кукуруза служит хорошим предшественником для посевов озимых культур растений. Ценность предшественника заключается в том, что использование более раннеспелого материала позволяет проводить уборку гораздо раньше и подготавливать поля для посевов озимых культур [3].

Основное назначение кукурузы в нашей стране в основном сводится к производству кормов для сельскохозяйственных животных, также кукурузное зерно служит качественным сырьём для производства спиртовой продукции, крахмала и кукурузного масла [2, 5].

Учёные-селекционеры из различных климатических зон Российской Федерации отмечают, что незаменима роль данной культуры в экономической и продовольственной составляющей таких регионов как Поволжье, Предуралье, Северный Кавказ и многие другие. Отмечается, что в этих регионах посевы раннеспелых и среднеранних гибридов кукурузы занимают значительные площади по сравнению с посевами других культурных растений [1].

Возможность использования новых сортов и линий в качестве родительских форм при скрещивании в гибридных комбинациях определяется не только их морфо-биологическими признаками, но также способностью нового исходного материала проявлять высокий гетерозисный эффект гибридов первого поколения. Метод получил название комбинационная способность. Использование метода определения комбинационной способности занимает важное место в селекции на гетерозис. Генетическая ценность нового исходного материала различна. Комбинационная способность позволяет выделять родительские формы с высокой и низкой комбинационной способностью для дальнейшего составления селекционных программ. Выборка родительских форм для селекции основывается на данных общей и специфической комбинационной способности исследуемого материала [6, 7].

В селекции на гетерозис подбор исходного материала с высокой комбинационной способностью занимает важное место, так как именно высокие ранги комбинационной способности позволяют получать лучшие гибридные комбинации.

Изучению общей комбинационной способности нового исходного материала большое внимание уделяли многие отечественные и зарубежные селекционеры. Комбинационная способность - это высоконаследуемое генетически обусловленное свойство исходного материала, позволяющее по хозяйственно-ценным признакам выделять новые родительские формы исследуемой культуры растений $[4,8]$.

\section{Цель исследований}

Оценить общую комбинационную способность новых раннеспелых и среднеранних автодиплоидных линий кукурузы

\section{Материалы и методы}

Работа проводилась в 2017-2020 гг. на опытных полях Национального центра зерна им. П.П. Лукьяненко в условиях богарного земледелия. В проведенном исследовании принимало участие 51 линия кукурузы, из них 28 раннеспелых и 23 среднеранние линии. Оценку общей комбинационной способности производили при помощи дисперсионного анализа в пакете программ Microsoft Office Excel.

Для создания нового исходного материала были взяты 6 линий из генетической коллекции отдела селекции и семеноводства кукурузы НЦЗ им. П.П. Лукьяненко: КР 802 МВ, КР 768/91 MB, KP 244 MB, KP 801 MB, KP 3070 МВ. Данный исходный материал обладал широкой генетической основой и относился к таким гетерозисным группам как: Lancaster, Dento Rio Gradense Rigoso и Stiff Stalk Synthetic.

Далее на новом исходном материале было заложено 5 гибридных комбинаций: КР 244 MB х КР 802 MB, KP 733/6 MB x KP 802 MB, KP 244 MB x KP 768/91 $1_{4-1-2}$, КР 3070 MB x KP 802 МВ и КР 801 MB x KP 733/6 МВ. На данном гибридном материале была начата работа по получению гаплоидов методом, разработанным Шацкой О.А. с соавторами [10].

Далее новый полученный исходный материал скрестили в селекционном питомнике по методике топ - кроссов, каждый блок линий с 3-мя тестерами. Для проведения топ - кроссных скрещиваний для блока раннеспелых линий были использованы тестера: КР 742 М, КР 714 М и КР 742 х 770 . Для проведения топ - кроссных скрещиваний в блоке среднеранних линий были использованы тестера гибриды: КР 640602 ${ }_{18-1-1}$ x KP $757602_{4-1-2}$, КР 640 М x 651 и КР 640 M x KP $757602_{4-1-2}$. Набор из шести используемых тестеров принадлежал к гетерозисной группе Ident. Опыление проводили по следующей общепринятой методике: до появления рылец початок изолировался пергаментным изолятором. Во время массового цветения початков изолятор снимали и принудительно опыляли пыльцой необходимой линии.

\section{Результаты и обсуждение}

Как известно из литературных источников основное влияние на показатели комбинационной способности оказывают погодные условия [9]. Как видно из рисунка 1 в 2018 году исследования среднедекадные температуры были наивысшими, что в достаточной мере, негативно сказалось на продуктивности новых гибридов кукурузы. Показано, что 2019 год исследования обладал наиболее благоприятным температурным режимом. В вегетационно важные этапы развития растений температура была на уровне или немного выше среднемноголет- 
него показателя. Условия 2020 года исследований оказались весьма спорным. В вегетационно важные периоды развития растений среднедекадная температура была значительно выше среднемноголетнего показателя, что негативно сказалось на продуктивности гибридов кукурузы.

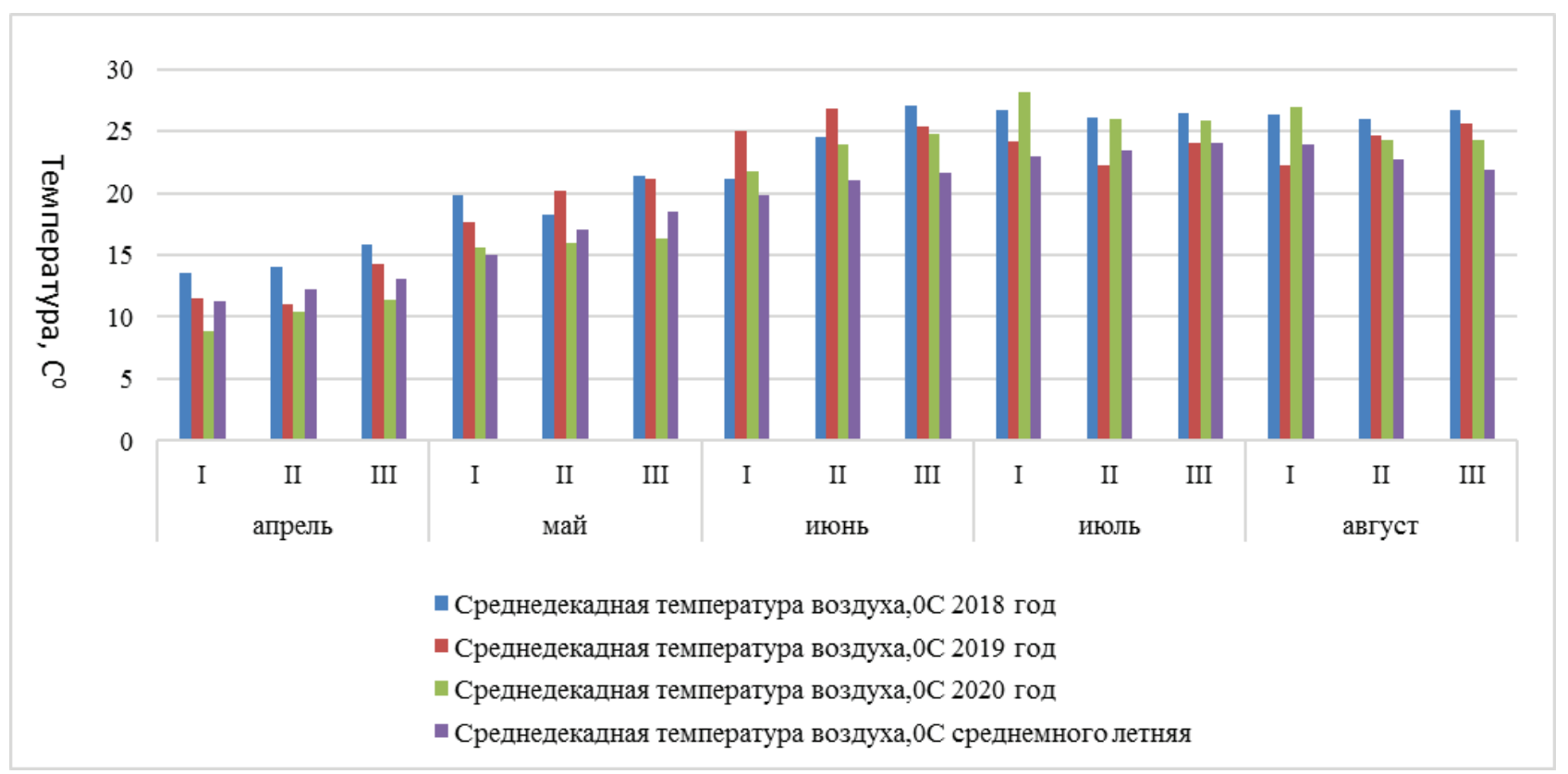

Рисунок 1. Среднедекадная температура воздуха по данным метеостанции НЦ3 2018 - 2020 год

Помимо температурного режима, одним из ключевых факторов развития гибридов кукурузы является количество выпавших осадков в вегетационно важные периоды. Как видно из рисунка 2, в условиях 2018 года количество выпавших осадков ока- залось значительно ниже, чем среднемноголетний показатель. Количество выпавших осадков 2019 и 2020 года в вегетационно важные периоды было на уровне или выше, чем среднемноголетний показатель.

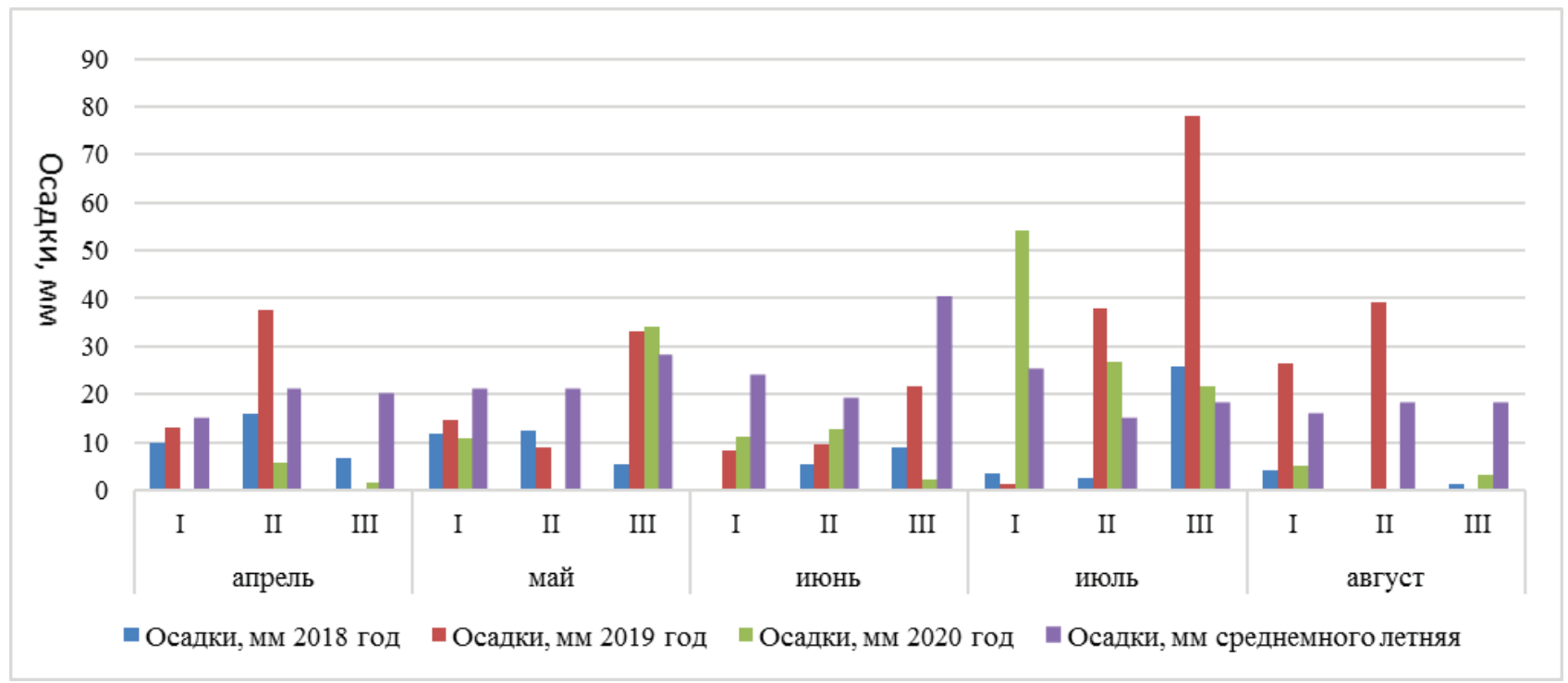

Рисунок 2. Среднедекадное количество осадков по данным метеостанции НЦЗ 2018 - 2020 год

Несмотря на сложные погодные условия трёх годов проведения исследований, удалось выделить новые раннеспелые и среднеранние автодиплоидные линии кукурузы, показавшие наилучшие результаты по величине эффектов общей комбинационной способности в каждом из годов исследования. Данные представлены в таблицах 1-4. 
Таблица 1. Эффекты ОКС раннеспелых линий кукурузы

\begin{tabular}{|c|c|c|c|}
\hline \multirow{2}{*}{$\begin{array}{c}\text { Наиме- } \\
\text { нование } \\
\text { линий }\end{array}$} & \multicolumn{3}{|c|}{$\begin{array}{c}\text { Эффекты ОКС раннеспелых } \\
\text { линий }\end{array}$} \\
\hline & 2018 год & 2019 год & 2020 год \\
\hline $1524_{/ 2}$ & $-3,79$ & $-6,37$ & $-1,39$ \\
\hline $1524_{/ 2-1}$ & $-3,19$ & $-4,24$ & 2,23 \\
\hline $1524_{/ 4}$ & $-6,18$ & 4,44 & $-6,63$ \\
\hline $1524_{/ 7}$ & 6,03 & 2,50 & 1,29 \\
\hline $1524_{/ 8}$ & 4,25 & 2,63 & 3,72 \\
\hline $1524_{/ 13}$ & 3,68 & $-1,04$ & $-6,81$ \\
\hline $1524_{/ 17}$ & 8,56 & $-2,28$ & 0,32 \\
\hline $1524_{/ 22}$ & $-2,52$ & 3,21 & $-9,02$ \\
\hline $1525_{/ 7}$ & 3,75 & $-1,52$ & $-3,87$ \\
\hline $1525_{/ 10}$ & $-3,35$ & 0,50 & $-12,94$ \\
\hline $1525_{/ 3}$ & 0,15 & $-8,67$ & $-13,17$ \\
\hline $1525_{/ 15}$ & $-3,15$ & 5,74 & $-10,50$ \\
\hline $1525_{/ 20}$ & 3,33 & $-1,95$ & $-3,74$ \\
\hline $1525_{/ 26}$ & $-1,81$ & $-2,70$ & $-19,30$ \\
\hline $1525_{/ 29}$ & $-0,02$ & 0,62 & 0,23 \\
\hline $1525_{/ 32}$ & 5,16 & 7,50 & 9,43 \\
\hline $1525_{/ 79}$ & $-2,22$ & 9,15 & $-0,73$ \\
\hline $1525_{/ 80}$ & $-0,28$ & 6,27 & 5,71 \\
\hline $1525_{/ 81}$ & $-3,06$ & $-0,26$ & $-10,23$ \\
\hline $1525_{/ 86}$ & 6,47 & $-1,95$ & 16,02 \\
\hline $1525_{/ 89}$ & 1,03 & $-2,23$ & 9,08 \\
\hline $1526_{/ 1}$ & $-0,12$ & $-6,20$ & 17,60 \\
\hline $1527_{/ 1}$ & 5,74 & 2,60 & 1,80 \\
\hline $1528_{/ 24}$ & $-3,97$ & 1,25 & 9,98 \\
\hline $1528_{/ 25}$ & $-9,95$ & 0,77 & $-12,49$ \\
\hline $1529_{/ 2}$ & 0,05 & $-5,79$ & 0,94 \\
\hline $1529_{/ 9}$ & $-3,92$ & 3,62 & 2,09 \\
\hline $1529_{/ 14}$ & $-1,00$ & $-6,61$ & $-4,03$ \\
\hline $\mathrm{HCP}_{05}$ & 1,62 & 2,61 & 3,50 \\
\hline
\end{tabular}

Таблица 2. Эффекты ОКС раннеспелых тестеров кукурузы

\begin{tabular}{|l|c|c|c|}
\hline \multirow{2}{*}{$\begin{array}{c}\text { Наименова- } \\
\text { ние тестера }\end{array}$} & \multicolumn{3}{|c|}{ Эффекты ОКС раннеспелых } \\
\cline { 2 - 4 } & $\mathbf{2 0 1 8}$ год & 2019 год & 2020 год \\
\hline 742 3М & 0,58 & $-0,76$ & 3,65 \\
\hline $7143 \mathrm{M}$ & $-1,61$ & $-2,54$ & $-6,22$ \\
\hline $742 \mathrm{M} \times 770$ & 1,03 & 3,30 & 2,58 \\
\hline $\mathrm{HCP}_{05}$ & 1,62 & 2,61 & 3,50 \\
\hline
\end{tabular}

Как видно из таблицы 1 наилучшими показателями эффектов общей комбинационной способности за три года исследования обладали линии: 1524 , $1524_{/ 8}, 1525_{/ 32}, 1527_{/ 1}$. Эффекты ОКС данных линий были положительными на протяжении трех лет исследования.

\section{Таблица 3. Эффекты ОКС среднеранних линий} кукурузы

\begin{tabular}{|c|c|c|c|}
\hline \multirow{2}{*}{$\begin{array}{c}\text { Наиме- } \\
\text { нование } \\
\text { линий }\end{array}$} & \multicolumn{3}{|c|}{$\begin{array}{c}\text { Эффекты ОКС среднеранних } \\
\text { линий }\end{array}$} \\
\hline & 2018 год & 2019 год & 2020 год \\
\hline $1524_{/ 3}$ & $-1,71$ & 2,75 & $-2,64$ \\
\hline $1524_{/ 6}$ & 6,62 & 3,35 & $-6,45$ \\
\hline $1524_{/ 12}$ & 0,27 & $-7,05$ & $-2,58$ \\
\hline $1524_{/ 16}$ & 1,89 & $-1,22$ & 0,12 \\
\hline $1524_{/ 26}$ & $-7,04$ & $-1,18$ & $-9,02$ \\
\hline $1524_{/ 36}$ & 4,79 & $-6,81$ & $-10,38$ \\
\hline $1524_{/ 52}$ & $-2,76$ & $-5,82$ & $-15,45$ \\
\hline $1525_{/ 2}$ & 4,16 & $-10,69$ & 5,36 \\
\hline $1525_{/ 28}$ & $-1,87$ & $-5,35$ & 1,68 \\
\hline $1525_{/ 36}$ & $-4,41$ & 5,00 & 8,86 \\
\hline $1525_{/ 69}$ & $-7,33$ & 8,30 & $-8,30$ \\
\hline $1525_{/ 77}$ & $-0,95$ & 3,26 & 1,54 \\
\hline $1525_{/ 78}$ & $-0,84$ & $-3,41$ & $-14,88$ \\
\hline $1525_{/ 86}$ & 1,18 & 0,46 & $-9,06$ \\
\hline $1526_{/ 3}$ & 4,01 & 0,95 & 6,23 \\
\hline $1528_{/ 2}$ & $-2,88$ & $-5,03$ & 1,92 \\
\hline $1528_{/ 4}$ & 1,45 & $-3,66$ & 4,08 \\
\hline $1528_{/ 5}$ & 8,29 & $-2,14$ & 10,89 \\
\hline $1528_{/ 6}$ & $-1,25$ & 3,23 & 12,11 \\
\hline $1528 / 12$ & 0,21 & 0,50 & 10,74 \\
\hline $1528_{/ 13}$ & 2,36 & 6,26 & $-1,55$ \\
\hline $1528_{/ 28}$ & $-3,75$ & 4,33 & 4,35 \\
\hline $1529_{/ 6}$ & $-4,84$ & 0,26 & $-17,72$ \\
\hline $\mathrm{HCP}_{05}$ & 2,21 & 2,62 & 3,37 \\
\hline
\end{tabular}

Таблица 4. Эффекты ОКС среднеранних тестеров кукурузы

\begin{tabular}{|l|c|c|c|}
\hline \multirow{2}{*}{$\begin{array}{c}\text { Наимено- } \\
\text { вание те- } \\
\text { стера }\end{array}$} & \multicolumn{3}{|c|}{ Эффекты ОКС среднеранних } \\
\cline { 2 - 4 } & 2018 год & 2019 год & 2020 год \\
\hline $\begin{array}{l}640602 \times \\
757602\end{array}$ & 1,32 & $-2,54$ & 2,28 \\
\hline $640 \mathrm{M}$ x 651 & $-1,43$ & 1,41 & 1,24 \\
\hline $\begin{array}{l}640 \mathrm{M} x \\
757602\end{array}$ & 0,12 & 1,13 & $-3,52$ \\
\hline $\mathrm{HCP}_{05}$ & 2,21 & 2,62 & 3,37 \\
\hline
\end{tabular}

Как видно из таблицы 3 наилучшими показателями эффектов общей комбинационной способности за три года исследования обладали линии: 1526/3, $1528_{12}$. Эффекты ОКС данных линий были положительными на протяжении трех лет исследования. 


\section{Выводы}

Таким образом, изучение комбинационной способности позволило нам выделить лучшие новые раннеспелые и среднеранние автодиплоидные линии кукурузы за три года исследования. Из блока раннеспелых линий выделились следующие линии: $1524_{/ 7}, 1524_{/ 8}, 1525 / 32,1527 / 1$.
Из блока среднеранних выделились следующие линии: $1526_{/ 3}, 1528_{/ 12}$. Исходя из полученных данных, нами были составлены селекционные программы использования новых раннеспелых и среднеранних линий кукурузы в зависимости от величины их эффектов общей комбинационной способности.

\section{ЛИТЕРАТУРА}

1. Бельченко, С.А. Влияние систем удобрения на урожайность и качество зелёной массы кукурузы / Бельченко С.А., Белоус Н.М., Драганская М.Г. // Достижения науки и техники АПК. Москва, - 2011. - № 5. - С. 59-61.

2. Васин, В.Г. Продуктивность и кормовая ценность гибридов кукурузы при применении минеральных удобрений и стимуляторов роста в условиях лесостепи Среднего Поволжья / Васин В.Г., Кошелева И.К. // Кормопроизводство. Москва, - 2017. - № 9. - С. 40-43.

3. Горбачева, А.Г. Реакция гибридов кукурузы на температурный режим в период прорастания/ А.Г. Горбачева, И.А. Ветошкина, А. Э. Панфилов, Е. С. Иванова // Кукуруза и сорго. Пятигорск, - 2014. - № 2. - С. $20-25$.

4. Гульняшкин, А.В. Оценка комбинационной способности новых самоопыленных линий в топкроссных скрещиваниях // А.В. Гульняшкин, И.М. Чилашвили, С.С. Попов // Отраслевой агропромышленный портал РусьАгроЮг, 2013 / электронный ресурс. Режим доступа: http://rusagroug.ru/articles/1729. (Дата обращения: 10.01.2021).

5. Дронов, А.В. Адаптивность и урожайность гибридов кукурузы различных по скороспелости в условиях Брянской области / Дронов А.В., Бельченко С.А., Ланцев В.В. // Вестник Брянской сельскохозяйственной академии. Брянск. - 2018. - С. 30 - 37.

6. Кривошеев, Г.Я. Общая и специфическая комбинационная способность самоопыленных линий кукурузы по признаку «урожайность зерна» / Г.Я. Кривошеев, Н.А. Шевченко // Научный журнал КубГАУ. - Краснодар, 2014. №104(10). - С. 664 - 674.

7. Кривошеев, Г.Я. Комбинационная способность раннеспелых самоопыленных линий кукурузы и тестеров в системе топкроссных скрещиваний / Г.Я. Кривошеев, А.С. Игнатьев, Н.А. Шевченко // Научный журнал КубГАУ. Краснодар, 2015. - №114 (10). - С. 1406 - 1416.

8. Супрунов, А.И. Оценка нового исходного материала для селекции средних и среднепоздних гибридов кукурузы / А.И. Супрунов, И.М. Чилашвили, С.С. Попов // Проблемы и тенденции инновационного развития агропромышленного комплекса и аграрного образования России. - Персиановский, 2012. - №2. - С. 167 - 171.

9. Чилашвили, И.М. Изучение комбинационной способности новых самоопылённых линий кукурузы в условиях центральной зоны Краснодарского края / И.М. Чилашвили, А.И. Супрунов, А.Ю. Слащев // Зерновое хозяйство России. - Зерноград, 2015. - №4. - С. 46 - 49.

10. Шацкая, О.А. Результаты использования метода гаплоидии в селекции кукурузы / О.А. Шацкая // Кукуруза и сорго. - Пятигорск, 2001. - № 4. - С. 14 - 17.

\section{REFERENCES}

1. Belchenko, S.A. Influence of fertilization systems on yield and quality of green mass of corn / Belchenko S.A., Belous N.M., Drahanskaya M.G. // Achievements of science and technology of the agro-industrial complex. Moskva, - 2011. - № 5. - P. 59-61.

2. Vasin, V.G. Productivity and fodder value of maize hybrids when using mineral fertilizers and growth stimulants in the forest-steppe conditions of the Middle Volga region / Vasin V.G., Kosheleva I.K. // Feed production. Moskva. - 2017. - №. 9. - P. 40-43.

3. Gorbacheva, A.G. Reaction of corn hybrids to temperature conditions during germination / A.G. Gorbacheva I.A. Vetoshkina, A.E. Panfilov E.S. Ivanova // Corn and sorghum. Pyatigorsk. - 2014.- № 2. - P. 20-25.

4. Gulnyashkin, A.V. Assessment of the combining ability of new self-pollinated lines in topcross crosses // A.V. Gulnyashkin I. M. Chilashvili, S.S. Popov // Industrial agro-industrial portal RusAgroYug, 2013. / electronic resource. Access mode: http://rusagroug.ru/articles/1729. (date of the application: 10.01.2021).

5. Dronov, A.V. Adaptability and productivity of maize hybrids of different early maturity in the conditions of the Bryansk region / Dronov A.V., Belchenko S.A., Lantsev V.V. // Bulletin of the Bryansk Agricultural Academy. - Bryansk, 2018. - P. $30-37$.

6. Krivosheev, G.Y. General and specific combining ability of self-pollinated corn lines on the basis of "grain yield" / G.Y. Krivosheev, N.A. Shevchenko // Scientific journal of KubSAU. - Krasnodar, 2014. - № 104 (10). - P. 664 - 674.

7. Krivosheev, G.Y. Combination ability of early maturing self-pollinated corn lines and testers in the system of topcross crosses / G.Y. Krivosheev, A.S. Ignatiev, N.A. Shevchenko // Scientific journal of KubSAU. - Krasnodar, 2015. - № 114 (10). - P. 1406 - 1416. 
8. Suprunov, A.I. Evaluation of a new source material for breeding medium and medium late corn hybrids / A.I. Suprunov, I.M. Chilashvili, S.S. Popov // Problems and trends in innovative development of the agro-industrial complex and agrarian education in Russia. - Persianovsky, 2012. - № 2. - P. 167 - 171.

9. Chilashvili, I.M. Study of the combinational ability of new self-pollinated corn lines in the central zone of the Krasnodar Territory. Chilashvili, A.I. Suprunov, A. Y. Slashchev // Grain economy of Russia. - Zernograd, 2015. - № 4. - P. 46 - 49.

10. Shatskaya, O.A. Results of using the haploidy method in corn breeding / O.A. Shatskaya // Corn and sorghum. Pyatigorsk, 2001. - № 4. - P. 14 - 17.

\section{Перевязка Дмитрий Сергеевич}

Младший научный сотрудник отдела селекции и семеноводства кукурузы

Тел. +79286645814

E-mail: dmitriy_perevyazka@mail.ru

\section{Перевязка Наталья Игоревна}

Младший научный сотрудник отдела селекции и семеноводства кукурузы

\section{Супрунов Анатолий Иванович}

Заведующий отделом селекции и семеноводства кукурузы

Bсе: ФГБНУ «НЦЗ им. П.П. Лукьяненко» г. Краснодар, Центральная Усадьба КНИИСХ

\section{Perevyazka Dmitry Sergeevich}

Junior researcher of the department of selection and seed production of corn

Phone. +79286645814

E-mail: dmitriy_perevyazka@mail.ru

\section{Perevyazka Natalia Igorevna}

Junior researcher of the department of selection and seed production of corn

\section{Suprunov Anatoly Ivanovich}

Head of the department of selection and seed production of corn

All: FSBSI «National Grain Centre named

after P.P. Lukyanenko»

Tsentral'naya Usad'ba KNIISKH,

Krasnodar, 350012, Russia 


\section{ИССЛЕДОВАНИЕ ЭФФЕКТИВНОСТИ РАЗЛИЧНЫХ СПОСОБОВ СТЕРИЛИЗАЦИИ ЭКСПЛАНТОВ СКУМПИИ КОЖЕВЕННОЙ (СОTINUS COGGYGRIA) В УСЛОВИЯХ МИКРОКЛОНАЛЬНОГО РАЗМНОЖЕНИЯ}

Клональное размножение является высокоэффективным методом и позволяет раскрыть потенциал растительных организмов к размножению. Микроразмножение в условиях in vitro невозможно без соблюдения стерильных условий, поэтому подбор стерилизующих агентов является одним из самых важных этапов данного вида размножения. В настоящем исследовании было проведено сравнение нескольких дезинфицирующих средств, позволяющих проводить эксперименты в асептических условиях, а также подбор наиболее эффективного режима стерилизации. В качестве первичных эксплантов использовали пазушные почки древесных растений вида скумпия кожевенная (Cotinus coggygria). Стерилизация проводилась в два этапа: поверхностная и основная. Вторичная проводилась в условиях бокса биологической безопасности, были подобраны три стерилизующих агента: Лизоформин 3000, хлоргексидин, пероксид водорода. Все вышеперечисленные вещества были отобраны ввиду ценовой доступности, а также возможности свободного приобретения. Было проведено сравнение режимов стерилизации по времени экспозиции. Наиболее результативным из трёх отобранных препаратов при обеззараживании эксплантов является стерилизующий агент Лизоформин 3000. Данный раствор при времени экспозиции, равному 3 минуты, дает 100 \% выход стерильных эксплантов при проведении микроразмножения растений, в частности скумпии кожевенной. При этом пероксид водорода имеет потенциал в использовании в качестве стерилизатора, поскольку процент стерильности образцов при наивысшем выбранном времени действия 3 \% раствора значительно увеличивается в сравнении с менее продолжительными режимами стерилизации. Таким образом, дальнейшая корректировка экспозиции пероксида водорода имеет перспективу получения дополнительного эффективного метода стерилизации.

Ключевые слова: скумпия кожевенная, in vitro, микроклональное размножение, стерилизация.

\section{STUDY OF EFFICIENCY OF DIFFERENT METHODS OF STERILIZATION OF EXPLANTS OF LEATHER SCUMPY (COTINUS COGGYGRIA) UNDER MICROCLONAL REPRODUCTION}

Clonal reproduction is a highly effective method and allows you to reveal the potential of plant organisms for reproduction. Micropropagation in vitro is impossible without observing sterile conditions; therefore, the selection of sterilizing agents is one of the most important stages of this type of reproduction. In the present study, a comparison was made of several disinfectants that allow experiments to be carried out under aseptic conditions, as well as the selection of the most effective sterilization regimen. The axillary buds of woody plants of the species Cotinus coggygria were used as primary explants. Sterilization was carried out in two stages: superficial and main. The secondary was carried out in a biological safety box, three sterilizing agents were selected: Lysoformin 3000, chlorhexidine, hydrogen peroxide. All of the above substances were selected due to their affordability, as well as the possibility of free purchase. A comparison was made between the sterilization modes in terms of exposure time. The most effective of the three selected preparations for disinfecting explants is the sterilizing agent Lizoformin 3000. This solution, with an exposure time of 3 minutes, gives $100 \%$ yield of sterile explants during micropropagation of plants, in particular Skumpia tannery. At the same time, hydrogen peroxide has the potential to be used as a sterilizer, since the percentage of sterility of samples at the highest selected time of action of a 3\% solution significantly increases in comparison with shorter sterilization regimes. Thus, further adjustment of the exposure to hydrogen peroxide has the prospect of obtaining an additional effective method of sterilization.

Keywords: Skumpia tannery, in vitro, micropropagation, sterilization.

\section{Введение}

Создание защитных лесонасаждений и рациональное озеленение городских территорий является актуальным вопросом для всех регионов страны. Волгоградская область располагается в степной, полупустынной и частично в лесостепной зонах, ей свойственен засушливый с резко выраженной континентальностью климат, что обусловливает необходимость в посадке соответствующих видов древесных растений. 
Потребность в повышении биоразнообразия и научный интерес к данной проблеме требуют серьезного изучения биологических ресурсов и подбора видов, соответствующих определенным требованиям. Таким как, жаро- и засухоустойчивость, неприхотливость в уходе, устойчивость к городским условиям, морозостойкость и привлекательный внешний вид, обеспечивающий декоративную функцию.

Потенциальным озеленителем города можно считать кустарниковое растение рода Скумпия, семейства Анакардиевые. Это небольшое дерево или кустарник, который достигает в высоту до 5 м, крона шаровидная, цветение в мае-июне. Растение засухоустойчиво и светолюбиво, избыток влаги может оказаться губителен, к промышленным условиям устойчиво [1]. В культуре скумпия растет на различных почвах, в том числе на слабо засоленных, но предпочитает глубокие карбонатные: черноземные, темно-каштановые, каштановые. Однако, скумпия требует укрытия на зиму и её необходимо высаживать в местах, защищенных от ветра.

Скумпия кожевенная также выполняет противоэрозийные и почвозащитные функции. Листья содержат 15-20 \% дубильных веществ, большую часть из которых составляет танин [2]. Помимо этого, в листьях содержатся галловая кислота, флавоноиды, эфирное масло, содержащее мирцен, $\alpha$-пинен, камфен, линалоол и $\alpha$-терпинеол [3]. Имеются данные об антимикробной активности экстрактов скумпии в отношении бактерий рода Staphylococcus [9].

Данная культура имеет экологическую и экономическую значимость, однако, при её размножении традиционными методами возникают определенные трудности. Например, семена скумпии имеют плотную оболочку, что значительно затрудняет данный способ размножения [3, 4]. Другим вегетативным методом является черенкование, но здесь большую роль играют погодные условия [4]. Таким образом, при выборе способа размножения данного растения следует обратить внимание на высокоэффективные методы, позволяющие стабильно и массово получать C. Coggygria. Одним из таких методов является микроклональное размножение, в котором большое значение придается соблюдению стерильных условий на всех этапах получения микроклонов растений $[5,6,7,8]$.

\section{Цель исследований}

Сравнить различные способы стерилизации эксплантов скумпии кожевенной в условиях микроклонального размножения.

\section{Материалы и методы}

Экспериментальные и теоретические исследования проводились на базе лаборатории биотехнологий ФНЦ агроэкологии РАН, а также в ФГАОУ ВО ВолГУ.

Работа в условиях ламинарного бокса, а также приготовление и автоклавирование питательных сред, подготовка посуды, обработка помещения, стерилизация посуды и инструментов проводились согласно общепринятым стандартам и методикам работы в асептических условиях [10].

В качестве первичных эксплантов использовали пазушные почки древесных растений вида скумпия кожевенная (Cotinus coggygria), взятые в осенний период покоя.

Стерилизация осуществлялась в два этапа. Первичную поверхностную стерилизацию проводили промыванием в течение 5 минут в 2 \%-ом мыльном растворе с дальнейшей отмывкой под проточной водопроводной водой.

Вторичная основная стерилизация проводилась в условиях бокса биологической безопасности БМБ-II «Ламинар-C» NEOTERIC. Материалы исследования выдерживали в различных растворах: 3 \% растворе Лизоформина 3000, 5 \% пероксида водорода, 0,05 \% хлоргексидина (табл. 1). Время экспозиции выбиралось на основе анализа литературы и предыдущих опытов [4, 8]. После выдержки в стерилизующих растворах экспланты промывали в автоклавированной дистиллированной воде.

Таблица 1. Варианты стерилизации эксплантов

\begin{tabular}{|c|c|c|}
\hline Стерилизующий агент & Содержание активного вещества, \% & Время экспозиции, мин \\
\hline \multirow{2}{*}{ Лизоформин 3000 } & \multirow{2}{*}{5} & 1 \\
\hline \multirow{2}{*}{ Пероксид водорода } & \multirow{2}{*}{3} & 5 \\
\hline & & 15 \\
\hline Хлоргексидин & \multirow{2}{*}{0,05} & 30 \\
\hline
\end{tabular}

Накаждыйвидстерилизующегоагентаприходилось 150 образцов, по 50 пробирок для каждого времени экспозиции. В качестве субстрата для выращивания была выбрана стандартная питательная среда Мурасиге-Скуга с добавлением 0,5 \% раствора витами- нов, 1 \% цитокина бензиламинопурина (6-БАП) и $1 \%$ ауксина а-нафтилуксусной кислоты (НУК).

Экспланты, прошедшие стерилизацию, с помощью пинцета помещали в стерильные пробирки на питательную среду и закрывали ватно-марлевыми 
пробками. В целях предотвращения высыхания среды, ввиду недостаточной влажности воздуха, поверх ватно-марлевых пробок пробирки накрывали фольгой. Образцы хранили в теплом, хорошо освещаемом помещении с доступом к солнечным лучам.

Результаты и обсуждение

Оценка состояния инокулированных почек и побегов, регенерированных из них в ходе культивирования на питательных средах проводилась ежедневно в течение месяца со дня начала эксперимента посредством визуального осмотра. Подсчет стерильных и инфицированных образцов осуществлялся на 15-ый и 30-ый день после введения в культуру in vitro (табл. 2).

Таблица 2. Сравнение способов стерилизации пазушных почек Скумпии кожевенной на этапе введения в культуру in vitro

\begin{tabular}{|c|c|c|c|c|c|c|c|c|c|}
\hline \multirow{3}{*}{$\begin{array}{c}\text { Параметры } \\
\text { Время выдержки (мин) }\end{array}$} & \multicolumn{9}{|c|}{ Стерилизующий агент } \\
\hline & \multicolumn{3}{|c|}{ Хлоргексидин } & \multicolumn{3}{|c|}{ Пероксид водорода } & \multicolumn{3}{|c|}{ Лизоформин 3000} \\
\hline & 15 & 20 & 30 & 15 & 20 & 30 & 1 & 3 & 5 \\
\hline $\begin{array}{l}\text { Контроль стерильности образцов через } \\
15 \text { дней (\%) }\end{array}$ & 40 & 40 & 20 & 60 & 60 & 80 & 80 & 100 & 100 \\
\hline $\begin{array}{l}\text { Контроль стерильности образцов через } \\
30 \text { дней (\%) }\end{array}$ & 0 & 0 & 20 & 20 & 20 & 40 & 40 & 100 & 100 \\
\hline
\end{tabular}

На 15-ый день наблюдения наименьший процент стерильных образцов равнялся 20, а к концу месяца почки в пробирках с несколькими вариантами стерилизации были на 100 \% поражены бактериальными и грибковыми инфекциями. При этом экспланты чаще всего поражались именно бактериальными инфекциями, что может свидетельствовать о наличии заболевания у маточного растения.

Лучшим результат был при использовании в качестве дезинфицирующего средства Лизоформина 3000 со временем экспозиции равному 3-5 минут.
Доля асептических образцов при этом составила 0 \% (рис. 1). Данный коммерческий препарат часто упоминается в трудах, посвященных теме микроклонального размножения, как хороший стерилизующий агент, не влияющий на жизнеспособность экспланта.

Менее эффективным оказалось действие хлоргексидина, обработка эксплантов которым не привела ожидаемому успешному результату. При максимальном времени выдержки, 30 минут, доля стерильных эксплантов составила 20 \%.

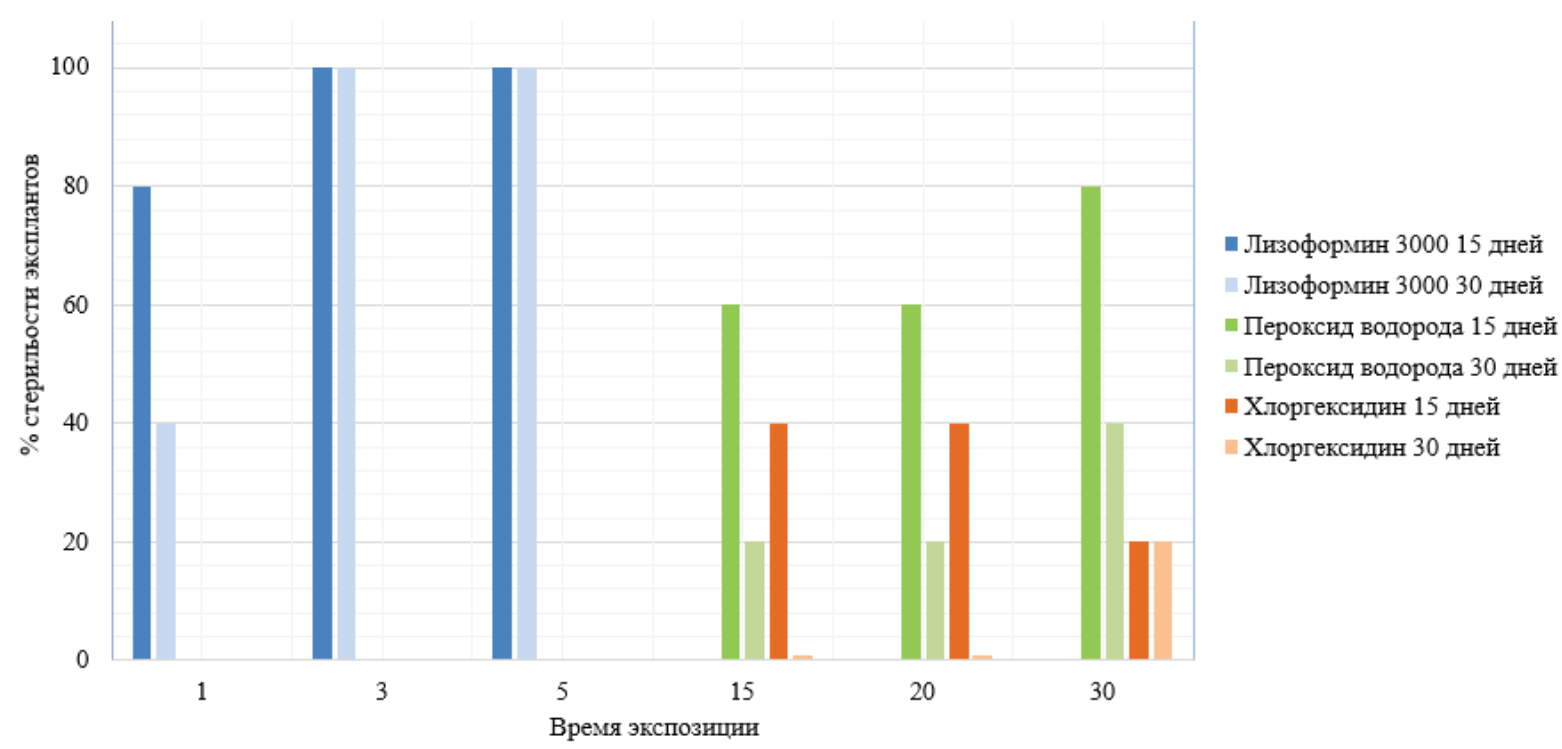

Рисунок 1. Сравнение приемов стерилизации C. Coggygria

Перспективным стерилизующим агентом можно считать пероксид водорода, при применении которого с увеличением времени экспозиции увеличивался процент стерильных эксплантов. В данном случае следует говорить о дальнейшей корректировки в сторону увеличения времени выдержки для получения лучшего результата.

\section{Выводы}

В рамках данного исследования было проведено сравнение нескольких антисептических средств и режимов стерилизации Скумпии кожевенной на этапе введения в культуру in vitro. Из трёх выбранных стерилизующих агентов наиболее эффективным оказался Лизоформин 3000: 3-х минутная вы- 
держка эксплантов в данном растворе дает 100 \% выход стерильных жизнеспособных образцов.

Стерилизация эксплантов хлоргексидином оказалась менее успешной, на 30-ый день наблюдений осталось лишь 20 \% стерильных эксплантов при времени экспозиции равному 30 минутам. При уменьшении времени выдержки к концу эксперимента число асептических образцов приравнивалось к нулю.

Использование пероксида водорода в качестве стерилизующего агента имеет потенциал и требует дальнейшего исследования в сторону увеличения времени экспозиции. Данный способ стерилизации имеет ряд преимуществ: он не требует больших финансовых затрат и более доступен в сравнении с другими дезинфицирующими средствами.

Таким образом, исходя из полученных результатов эксперимента, можно сделать вывод, что дальнейшие исследования и поиск широко доступных дезинфицирующих средств, имеют перспективу использования в первичной стерилизации эксплантов при подготовке к микроразмножению в условиях in vitro.

\section{ЛИТЕРАТУРА}

1. Блинова, К. Ф. Ботанико-фармакогностический словарь: Справ. пособие // - М.: Высш. шк., 1990. - С. 237.

2. Гроссгейм, А. А. Флора Кавказа // Изд. 2-е. Т. 6. МЛ Л., «Наука», 1962.

3. Губанов, И. А. Дикорастущие полезные растения СССР // М.: Мысль, 1976. - С. 220-222.

4. Деменко, В. И. Проблемы и возможности микроклонального размножения садовых растений // Известия TCXA, 2005. - № 2. - С. 48 - 58.

5. Калинин, Ф.Л. Технология микроклонального размножения растений/ Г.П.Кушнир, В.В. Сарнацкая // Киев: Наукова думка, 1992. - 232 с.

6. Калинин, Ф.Л. Методы культуры тканей в физиологии и биохимии растений / Ф.Л.Калинин, В.В.Сарнацкая, В.Е.Полищук // Киев: Наукова думка, 1980. - 486 с.

7. Катаева, Н.В. Клональное микроразмножение растений / Н.В. Катаева, Р.Г. Бутенко // М.: Наука, 1983. - 96 с.

8. Лебедь, М.Б. Исследование эффективности различных способов стерилизации эксплантов картофеля при микроклональном размножении / Лебедь М.Б., Берестнева Ю.В., Волков И.В., Бикметова К.Р., Лебедь Н.И. // Успехи современного естествознания. - 2019. - №9. - С. 26 - 30.

9. Майорова, А.В. Фитокомпоненты в составе средств постпилингового ухода: перспективы использования. Современные проблемы науки и образования / А.В. Майорова, С.Б. Евсеева, Н.А. Кливитская, Р.М. Гаджиева // 2015. - № 4 - С. 550.

10. Широков, А.И. Основы биотехнологии растений / А.И. Широков, Л.А. Крюков // Электронное учебно-методическое пособие. - Нижний Новгород: Нижегородский госуниверситет, 2012. - 49 с.

\section{REFERENCES}

1. Blinova, K.F. Botanical-Pharmacognostic Dictionary: Reference Manual // - M.: Vyssh. shk., 1990. - P. 237.

2. Grossheim, A.A. Flora of the Caucasus // Ed. 2-th. T. 6. ML, Nauka, 1962.

3. Gubanov, I.A. Wild useful plants of the USSR // Moscow: Mysl, 1976. - P. 220 - 222.

4. Demenko, V. I. Problems and opportunities of microclonal propagation of garden plants // Proceedings of the TSKHA, 2005. - № 2. - P. 48 - 58.

5. Kalinin, F.L. Technology of microclonal propagation of plants / G.P. Kushnir, V.V. Sarnatskaya // Kyiv: Naukova Dumka, 1992. - 232 c.

6. Kalinin, F.L. Tissue culture methods in plant physiology and biochemistry / F.L. Kalinin, V.V. Sarnatskaya, V.E. Polishchuk // Kiev: Naukova Dumka, 1980. - 486 p.

7. Kataeva, N.V. Clonal micropropagation of plants / N.V. Kataeva, R.G. Butenko // Moscow: Nauka, 1983. - 96 p.

8. Lebed, M.B. Study of effectiveness of different methods of sterilization of potato explants in microclonal propagation / Lebed M.B., Berestneva S.V., Volkov I.V., Bikmetova K.R., Lebed N.I. // Adv. of modern natural science. - 2019. - № 9. - P. 26-30.

9. Mayorova, A.V. Phytocomponents in the post-peeling care: prospects for use. Modern problems of science and education / A.V. Mayorova, S.B. Evseeva, N.A. Klivitskaya, R.M. Hajieva // 2015. - № 4 - P. 550.

10. Shirokov, A.I. Fundamentals of Plant Biotechnology / A.I. Shirokov, L.A. Kryukov // Electronic teaching aid. - Nizhny Novgorod: Nizhny Novgorod State University, 2012. - 49 p.

\section{Бикметова Кристина Романовна}

Младший научный сотрудник лаборатории биотехнологий

E-mail: c.bicmetowa@yandex.ru

\section{Смирнова Юлия Сергеевна}

Младший научный сотрудник лаборатории биотехнологий

E-mail: smirnova-yu@vfanc.ru

Bсе: ФНЦ агроэкологии РАН 400062, Россия, г. Волгоград, пр-т Университетский, 97

\section{Bikmetova Kristina Romanovna}

Junior Researcher, Biotechnology Laboratory

E-mail: c.bicmetowa@yandex.ru

\section{Smirnova Yulia Sergeevna}

Junior Researcher, Biotechnology Laboratory

E-mail: smirnova-yu@vfanc.ru

All: Federal Research Center of Agroecology of the Russian Academy of Sciences 97, Prospect University, Volgograd 400062, Russia 


\section{ОЦЕНКА ИНБРЕДНЫХ ЛИНИЙ И ГИБРИДНЫХ КОМБИНАЦИЙ БЕЛОКОЧАННОЙ КАПУСТЫ НА УСТОЙЧИВОСТЬ К СОСУДИСТОМУ БАКТЕРИОЗУ \\ (Xanthomonas campestris pv. campestris)}

Наиболее перспективным способом борьбы с опасным заболеванием белокочанной капусты сосудистым бактериозом является создание устойчивых гибридов. В полевых условиях оценивали устойчивость к сосудистому бактериозу 15 инбредных линий и 22 гибридов $F_{1}$ среднепоздней белокочанной капусты при искусственном заражении мелкодисперсным опрыскиванием водной суспензией патогена, представленного изолятами расы 1. Из них 5 инбредных линий и 10 гибридов протестировали на стеблевую устойчивость к расе 1 в рассадной культуре. Инбредные линии, созданные в течение ряда лет с применением различных методов искусственного заражения и отбора устойчивых биотипов, сочетали в той или иной мере различные виды устойчивости (стеблевую к расе 1, гидатодную, в основном к расе 1). Гибридные комбинации в качестве компонентов скрещивания имели одну или обе линии с устойчивостью. Ввиду жаркой, засушливой погоды инфекция не распространилась на листья среднего и верхнего яруса по мере формирования розетки и развитие заболевания оценивали по нижним листьям. Очень высокую устойчивость показали 5 линий и 2 гибрида (Сударыня $F_{1}$ и перспективный гибрид - msГеc1x Хн1ф861c). Высокая устойчивость отмечена у 5 линий и 2-х гибридов, среди них второй перспективный гибрид - (Агр82 х Юби122). Два гибрида из коллекции фирмы «Поиск» Бомонд $F_{1}$ и Дмитровский $F_{1}$ проявили высокую и среднюю устойчивость соответственно. При тестировании на стеблевую устойчивость к расе 1 в рассаде путем инокуляции в стебель через подрезанный семядольный лист установлено, что распространенность заболевания линий была в интервале от 0 до 50 \%, среди гибридов - от 12 до 50 \%, кроме одного, пораженного на $93 \%$ Коэффициент корреляции между развитием болезни в поле при заражении через гидатоды и распространением болезни при заражении через стебель - средней силы составил 0,56, что, надо полагать, связано с совместным проявлением разных типов устойчивости при слабо контролируемых условиях.

Ключевые слова: белокочанная капуста, линия, гибрид F1, Xanthomonas campestris pv. Campestris, стеблевая и гидатодная устойчивость.

\section{EVALUATION OF INBRED LINES AND HUBRID COMBINATIONS OF WHITE CABBAGE} FOR RESISTANCE TO BLACK ROT (Xanthomonas campestris pv. campestris))

The most promising way to control the black rot - dangerous disease of white cabbage is to develop resistant hybrids. Black rot resistance of 15 inbred lines and $22 F_{1}$ hybrids of medium late white cabbage wasevaluated in the field under artificial infection by finely dispersed spraying with an aqueous suspension of the pathogen represented by race 1 isolates. Of these, 5 inbred lines and 10 hybrids were tested for stem resistance to race 1 in seedling culture. Inbred lines, developed over a number of years using various methods of artificial infection and selection of resistant biotypes, combined to one degree or another different types of resistance (stem to race 1, hydatodic to races 1). Hybrid combinations had one or both resistant lines as components of the crossing. Due to the hot, dry weather, the infection did not spread to the leaves of the middle and upper layer as the rosette was formed and the development of the disease was assessed by the lower leaves. Very high resistance was shown by 5 lines and 2 hybrids (SudarynyaF, and a promising hybrid - msHes1x Xn1f861s). High resistance was noted in 5 lines and 2 hybrids, among them the second promising hybrid - (Agr82 x Yubi122). Two hybrids from the collection Bomond $F_{1}$ and Dmitrovsky $F_{1}$, showed high and medium resistance, respectively. When testing for stem resistance to race 1 in seedlings by inoculation into the stem through a trimmed cotyledon leaf, it was found that the prevalence of the disease in the lines was in the range from 0 to $50 \%$, among hybrids from 12 to 50\%, except for one affected by 93\%. The correlation coefficient between the development of the disease in the field during infection through the hydatods and the spread of the disease during infection through the stem is of average intensity and was 0.56, which, presumably, is associated with the joint manifestation of different types of resistance under poorly controlled conditions.

Key words: white cabbage, line, F1 hybrid, Xanthomonas campestris pv. Campestris, stem and hydatodic resistance 


\section{Введение}

Селекция белокочанной капусты на устойчивость к болезням является важной частью интегрированной защиты гибридов $F_{1}$. Сосудистый бактериоз распространенное и опасное заболевание по ряду причин: многообразие источников заражения - растительные остатки, почва, семена; различные способы проникновения инфекции: через гидатоды, устьица, механические повреждения всех частей растения; большое количество рас патогена (рис. 1), [3, 6, 7]. Для успешной борьбы с этим опасным заболеванием и предотвращения

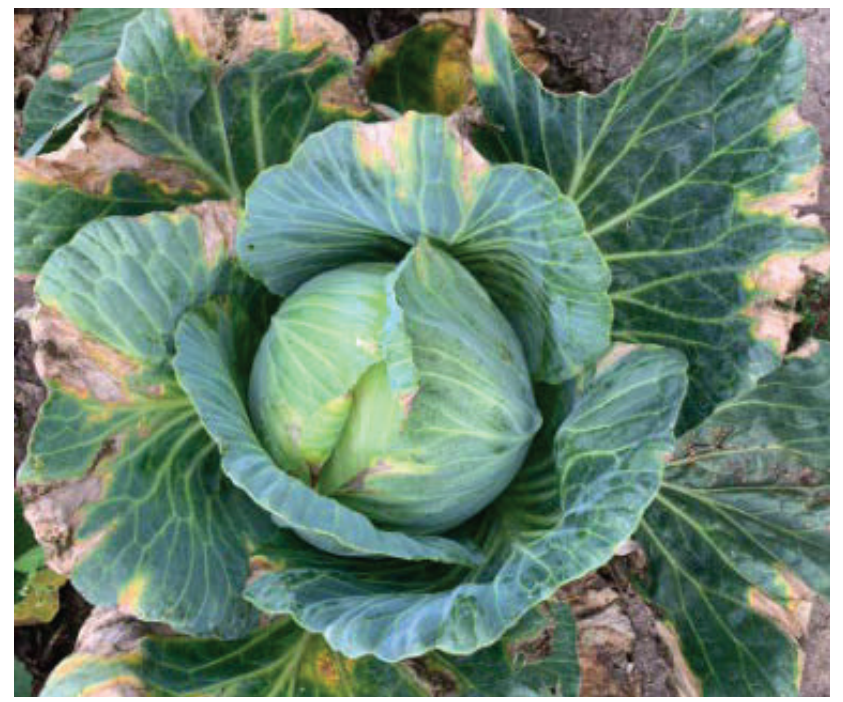

Рисунок 1. Проявление сосудистого бактериоза на восприимчивом гибриде $F_{1}$ Олимп

эпифитотий на посевах наших гибридов при создании устойчивых линий мы старались в одном генотипе объединить расоспецифическую и полигенную устойчивость $[2,9,10]$. В результате многолетней работы были созданы линии поздней белокочанной капусты, сочетающие различные виды устойчивости: расоспецифические - гидатодную и стеблевую, полигенную и гидатодную или полигенную и стеблевую [1, 2]. Надо отметить, что объединить в одном генотипе устойчивость к нескольким расам практически невозможно, тем более, устойчивость у капусты наследуется по рецессивному типу. Поэтому, мы основное внимание уделяли отбору биотипов к наиболее вредоносной в регионе расе $1[1,4]$. Линии с разной степенью устойчивости к сосудистому бактериозу в последние годы включаются в гибридизацию и полученные гибриды проходят оценку на хозяйственную полезность и устойчивость. В 2021 году включен в Госреестр селекционных достижений среднепоздний гибрид капусты Сударыня $\mathrm{F}_{1}$, жаростойкий, с комплексной устойчивостью: фузариозу, сосудистому бактериозу и табачному трипсу. Селекция на устойчивость в полевых условиях является составной частью любой селекционной программы. Поэтому, после 5-ти летнего перерыва, мы возобновили работу по оценке селекционного материала в поле с применением искусственного заражения. Это позволит контролировать проявление заболевания в динамике - от заражения до созревания кочанов.

\section{Цель исследований}

Дать фитопатологическую оценку линиям с расоспецифической устойчивостью к сосудистому бактериозу и гибридам $\mathrm{F}_{1}$ на их основе в полевых условиях с применением искусственного заражения.

\section{Материалы и методы}

Материал исследований - инбредные линии, гибриды $F_{1}$ на их основе.

Выделение возбудителей сосудистого бактериоза капусты в чистую культуру проводили в лабораторных условиях на питательных средах.

Место проведения исследований - изолированный участок, предшественник - тыква. Полив смешанный.

Для тестирования на стеблевую расоспецифическую устойчивость к сосудистому бактериозу инбредных линий и гибридов рассада была выращена в кассетах и инокулирована изолятами расы 1 путем подрезания семядольного листа [7].

Для оценки селекционного материала на устойчивость к сосудистому бактериозу рассаду, выращенную в кассете № 96, в фазе 4-5 листьев высаживали на участок по 20 растений на делянку. В фазе 5-6 листьев исследуемые образцы опрыскивали водной суспензией X. campestris с титром бактерий $10^{9}$ в 1 мл, согласно оптическому стандарту мутности [5]. Оценку поражаемости растений патогеном проводили в динамике по шкале Н.С. Сухоруковой [8].

\section{Результаты и обсуждение}

Надо отметить, что погодные условия 2020 года в период выращивания капусты (июль - октябрь) по температуре и влажности не способствовали развитию сосудистого бактериоза. С другой стороны, обильные осадки с градом, выпавшие 20 июля, повредили листовой аппарат зараженных растений, что не могло не отразиться на распространении инфекции. Тем не менее, проявление симптомов отмечали только спустя 2 недели после заражения. На среднем и верхнем ярусах розетки симптомы не проявились. Можно предположить, что отбор в линиях биотипов с расоспецифической стеблевой устойчивостью и полигенной устойчивостью защитил растения от дальнейшего проникновения инфекции по сосудам.

Наибольшую резистентность к патогену проявили 4 гибрида и 9 линий (табл. 1). Развитие болезни варьировало у них от 0 до 25 \%. Абсолютно не поразилась линия 269-Яс13 (70-2). Очень высокую устойчивость показал перспективный гибрид (msГес x Хн1ф861c) - с развитием болезни 8 \% и новый гибрид Сударыня $\mathrm{F}_{1}$ - с развитием 10 \% (рис. 2, 3). Второй перспективный гибрид - (Агрб82 х 


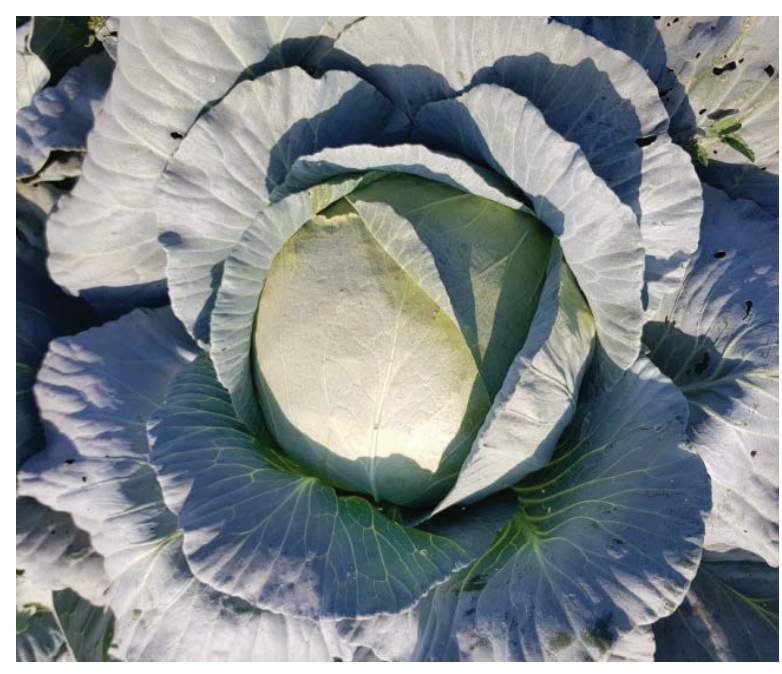

Рисунок 2. Гибрид $F_{1}$ Сударыня с очень высокой устойчивостью к сосудистому бактериозу

Юби122) - попал в группу с высокой устойчивостью (15\%) (рис. 4). 9 гибридов и 3 линии были оценены, как среднеустойчивые. Два коллекционных образца селекции фирмы «Поиск» показали высокую (Бомонд $\mathrm{F}_{1}$ ) и среднюю устойчивость (Дмитровский $\left.F_{1}\right)$. Надо отметить, что линии и гибриды на их основе с очень высокой стеблевой устойчивостью (72-3/19, 73-1/19, 5-1/19) проявили себя как слабо устойчивые при заражении через гидатоды. Но, если учесть, что поражение проявилось только на нижних листьях (в начале вегетации), то велика вероятность проявления стеблевой устойчивости на этих образцах, которая предотвратила дальнейшее развитие заболевания.

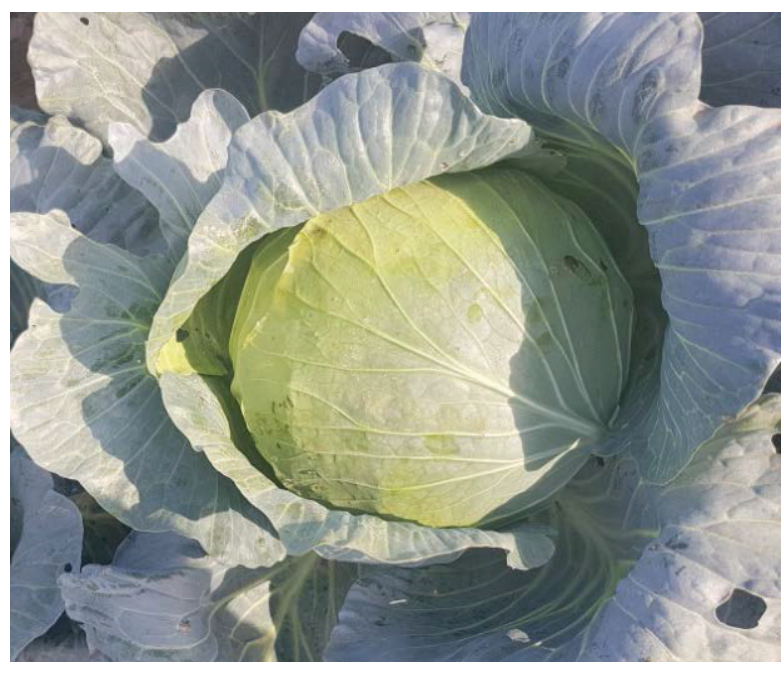

Рисунок 3. Перспективный гибрид (Гес1хХн861) с очень высокой устойчивостью к сосудистому бактериозу

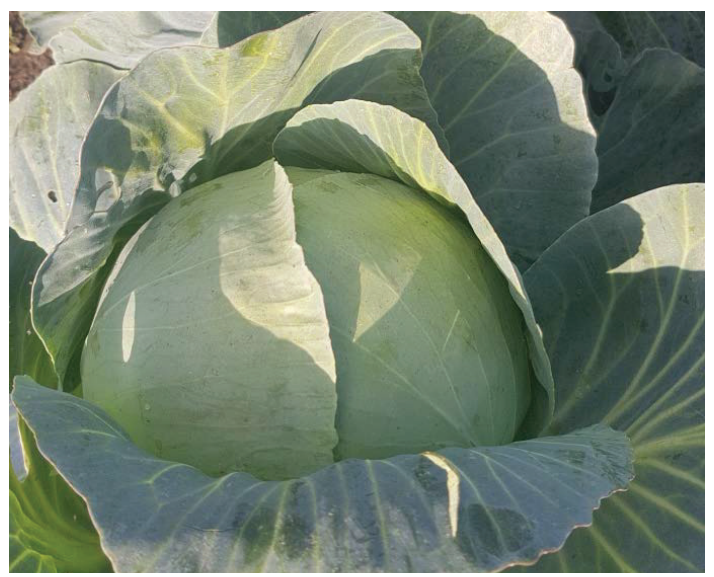

Рисунок 4. Перспективный гибрид (Агр82хЮби122) с высокой устойчивостью к сосудистому бактериозу

Таблица 1. Оценка селекционного материала капусты на устойчивость к сосудистому бактериозу в поле с искусственным заражением, 2020 г.

\begin{tabular}{|c|c|c|}
\hline Номер образца & Расшифровка образца & Развитие болезни, \% \\
\hline \multicolumn{3}{|c|}{ С очень высокой устойчивостью (0-10,0\%) } \\
\hline $\mathrm{ms} \Gamma \mathrm{ec} 1 \times 16-2 / 18$ & $\mathrm{~ms} \Gamma \mathrm{ec} 1 \times \mathrm{XH} 1 \mathrm{\phi} 861 \mathrm{c}$ & 8,0 \\
\hline $4 \mathrm{k}(20)$ & St. Сударыня $\mathrm{F}_{1}$ & 10,0 \\
\hline $5-1 / 19$ & Юби 122с & 8,0 \\
\hline $15-2$ & Агрф2 & 7,0 \\
\hline $34-2 / 19$ & Kop 1 & 7,5 \\
\hline $70-2 / 19$ & 269-9c13 & 0 \\
\hline $\mathrm{ms} Б \mathrm{c} 1 \phi / 19$ & $\mathrm{msБc} 1 \phi / 19$ & 10,0 \\
\hline \multicolumn{3}{|c|}{ С высокой устойчивостью $(10,1-25,0 \%)$} \\
\hline $14-1 / 19$ & Агр13-21 & 25,0 \\
\hline $6-1 \times 4 / 18$ & Агр82 x Юби122 & 15,0 \\
\hline Бомонд $\mathrm{F}_{1}$ & Бомонд $\mathrm{F}_{1}$ & 21,0 \\
\hline $46-6 / 19$ & Тен 211 & 12,5 \\
\hline $59-2 / 19$ & Тен4272п-1п & 20,0 \\
\hline $63-2 / 19$ & $2699 \mathrm{c} 13 п-1 \mathrm{c}-10$ & 17,0 \\
\hline
\end{tabular}


Продолжение таблицы 1

\begin{tabular}{|c|c|c|}
\hline Номер образца & Расшифровка образца & Развитие болезни, \% \\
\hline $60-3 / 19$ & Тен4272п-2с & 17,0 \\
\hline \multicolumn{3}{|c|}{ Со средней устойчивостью $(25,1-35)$} \\
\hline msБc1ф x 72/19 & msБc1ф x 270-4aХн144-24-9c & 32,0 \\
\hline $59-2 \times 5-1 / 19$ & Тен4272п-1п x Юби122с & 31,0 \\
\hline msБc1ф x 65-4/19 & msБc1ф x Яс25п & 26,0 \\
\hline $32-8 \times 73-1 / 19$ & msБc1фx 270-4aХн144-21-1 & 28,0 \\
\hline $63-1 \times 5-1 / 19$ & 269Яс13п1с x Юби122с & 27,0 \\
\hline $62-2 / 19$ & Хн270-14п-1с & 27,0 \\
\hline $4-1 \times 3-1 / 19$ & Юби122 x 269Хн1фс-2 & 26,0 \\
\hline $60-3 \times 5-1 / 19$ & Тен4272п2с х Юби122с & 31,0 \\
\hline $62-3 \times 5-1 / 19$ & Хн270-14п-1с х Юби122с & 31,0 \\
\hline $70-3 \times 5-1 / 19$ & 269Яс13-1с x Юби122с & 30,0 \\
\hline Дмитровский $\mathrm{F}_{1}$ & Дмитровский $\mathrm{F}_{1}$ & 33,0 \\
\hline $48-3 / 19$ & $269-827$ & 30,0 \\
\hline $67-3 / 19$ & 269Яс12п-2 & 33,0 \\
\hline \multicolumn{3}{|c|}{ Со слабой устойчивостью (35,1-50\%) } \\
\hline $15-1 \times 6 / 19$ & Агрф2 x Пар3п1432-3 & 44,6 \\
\hline $32-5 \times 67-2 / 19$ & msБc1ф x 269яс12п-2 & 46,0 \\
\hline $32-5 \times 3-2 / 19$ & msБc1ф x 269Xн1фс-2 & 43,0 \\
\hline $65-5 \times 5-1 / 19$ & Бр272-21п-1 хЮби122с & 40,0 \\
\hline $73-2 \times 5-1 / 19$ & 270-4аХн144-21-2с x Юби122с & 40,0 \\
\hline $72-3 \times 5-2 / 19$ & 270-4aХн144-24-2с x Юби122с & 42,5 \\
\hline St. Олимп $\mathrm{F}_{1}$ & Олимп $\mathrm{F}_{1}$ & 45,0 \\
\hline $72-3 / 19$ & $270-4 a \times+144-24-2 c$ & 44,0 \\
\hline $73-1 / 19$ & 270-4aХн144-21-2 & 39,0 \\
\hline $4-2 \times 5 / 18$ & Юби122-х Агр81 & 36,0 \\
\hline
\end{tabular}

В таблице 2 представлены результаты оценки 5 линий и 10 гибридов на устойчивость при разных способах заражения (через гидатоды и стебель). Высокую устойчивость при 2-х способах заражения показали линии Тен211 и Кор 1. У гибридов с участием устойчивой линии Юби122с стеблевая устойчивость варьировалась от 12 до 50 \%, в то время, как с неустойчивой линией msБc1ф гибридная комбинация проявила восприимчивость на уровне 93 \%, что указывает на то, что обе ли- нии должны быть с высокой устойчивостью. Ввиду того, что оценка вредоносности патогена учитывалась по повреждению листовой пластинки, и возможно совместное действие обоих видов устойчивости, проведена оценка зависимости показателей устойчивости образцов, используя коэффициент корреляции (r). Вычисления показали, что $r=0,56$, что соответствует средней степени связи, которая подтверждена критерием существенности $t_{r=}$ $2,43>t_{05=} 1,76$.

Таблица 2. Сравнение проявления разных видов устойчивости к сосудистому бактериозу на одних гибридах, 2019- 2020 г. г.

\begin{tabular}{|l|c|c|c|}
\hline Номер образца & Расшифровка линии, гибрида & $\begin{array}{c}\text { Развитие болезни, \%, } \\
\text { 2020 год }\end{array}$ & $\begin{array}{c}\text { Распространенность } \\
\text { болезни, \%, 2019 год }\end{array}$ \\
\hline $46-7$ & Тен211 & 12,5 & 0 \\
\hline $14-1$ & Агр1321 & 25 & 40 \\
\hline $48-2$ & $269-827$ & 30 & 12 \\
\hline $34-2$ & Кор1 & 7,5 & 0 \\
\hline $67-3$ & $269-Я с 12 п-2$ & 33 & 12 \\
\hline $63 \times 5$ & 269Яс13п1с х Юби122с & 27 & 37 \\
\hline $65 x 5$ & Бр272-21п-1 Юби122с & 40 & \\
\hline
\end{tabular}




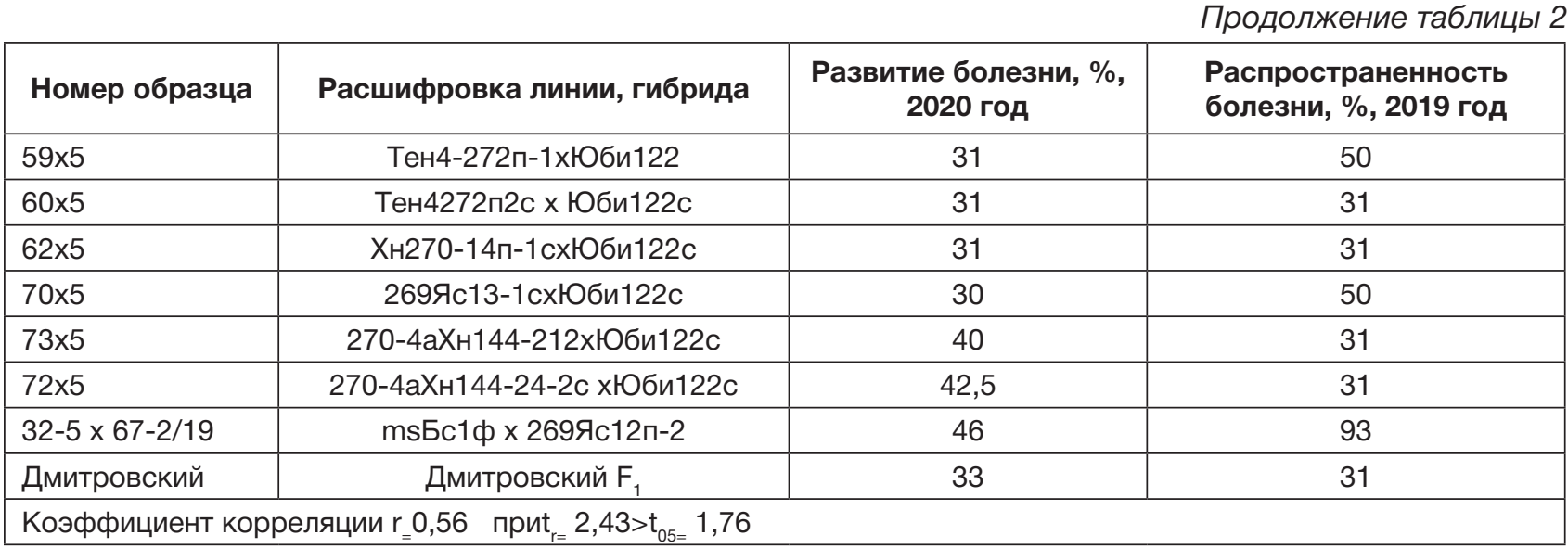

\section{Выводы}

При фитопатологической оценке 15 линий и 22 гибридов на их основе на расоспецифическую гидатодную устойчивость к сосудистому бактериозу при искусственном заражении в полевых условиях симптомы заболевания проявились только на обработанных листьях;

Инфекция не распространилась на листья среднего и верхнего яруса по мере формирования розетки листьев;

Очень высокую устойчивость показали 5 линий и 2 гибрида (Сударыня $\mathrm{F}_{1}$ и перспективный гибрид(msГec1 x Хн1ф861c);
Высокая устойчивость отмечена у 5 линий и 2-х гибридов, среди них второй перспективный гибрид (Агр82 x Юби122);

5 линий и 10 гибридов были протестированы на расоспецифическую стеблевую устойчивость, при этом распространенность заболевания варьировала от 0 до 93 \%;

Коэффициент корреляции между развитием болезни в поле при заражении через гидатоды и распространением болезни при заражении через стебель был средней силы и составил 0,56, что, надо полагать, связано с совместным проявлением разных типов устойчивости при слабо контролируемых условиях.

\section{ЛИТЕРАТУРА}

1. Дякунчак, С.А. Создание инбредных линий белокочанной капусты с групповой устойчивостью к фузариозу и сосудистому бактериозу/ С.А. Дякунчак, С.В. Королева // Рисоводство. - 2018. - №2(39).- С.74-79.

2. Дякунчак, С.А. Создание линий капусты белокочанной, устойчивых к сосудистому бактериозу / С.А. Дякунчак, С.В. Королева, С.А.Юрченко// Рисоводство. - 2017. - №2 (35). - С.60-64.

3. Игнатов, А. Н. Сосудистый бактериоз капустных в России - причины эпифитотии, методы защиты и источники селекции на устойчивость к болезням / А. Н. Игнатов, С. В. Панчук, Во ТхиНгок Ха, Е. С. Мазурин, К. А. Кромина, Ф.С, Джамилов // Картофель и овощи. - 2016. - № 2. - С. 25.

4. Королева, С.В. Создание гибридов F1 капусты белокочанной с комплексной устойчивостью на юге России / С.В. Королева, С.А. Дякунчак, С.А. Юрченко // Овощи России.- 2019.- №4.- С.16-20.

5. Королева, С.В. Иммунологическая оценка селекционного материала при создании гибридов F1 белокочанной капусты с групповой устойчивостью к фузариозу и сосудистому бактериозу/ Королева С.В., Дякунчак С.А., Ситников С.В. // (методические рекомендации) - Москва, 2012.-16 с.

6. Мазурин Е.С. Оценка разновидностей штаммов сосудистого бактериоза капусты / Е.С. Мазурин, А.Н. Игнатов, Е.В. Матвеева, Ф.С. Джалилов // Известия ТСХА. - 2010. - Вып. 5. - С.86-93.

7. Монахос, Г. Ф. Селекция капусты на устойчивость: состояние и перспективы / Г. Ф. Монахос, С. Г. Монахос, Г. А.Костенко // Картофель и овощи. - 2016. - № 12. - С. 31-35.

8. Сухорукова, Н.С. Методика оценки и селекционного отбора белокочанной капусты на устойчивость к сосудистому бактериозу. Автореф. дисс. канд. с.-х. наук. М.,1987. - 16 с.

9. Ignatov, A. Vascular stem resistance to black rot in Brassica oleracea / A. Ygnatov, Y. Kuginuki, K. Hida // Canadian Journal of Botany. -1999. - 77(3). - P. 442-446.

10. Vicente, J. Identification and origin of Xanthomonas campestris races and related palhovars / J. Vicente // Phytopathology. - 2001. - 91. - P. 492-499.

\section{REFERENCES}

1. Dyakunchak, S.A. Development of the inbreed lines of white cabbage with $f$ group resistance to fusarium and black rot/ S.A. Dyakunchak, S.V. Koroleva // Rice growing.- Krasnodar. 2018.-№ 2 (39) - P.74-79.

2. Dyakunchak, S.A. Creation of white cabbage lines resistant to black rot/ S.A. Dyakunchak, S.V. Koroleva, S.A. Yurchenko // Rice growing.- Krasnodar, 2017. -№2(35).- P.60-64.

4. Koroleva, S.V. Development of F1 hybrids of white cabbage with complex resistance in the south of Russia/ S.V. Koroleva, S.A. Dyakunchak, S.A. Yurchenko // Vegetable crops of Russia. 2019.- №4 - P.16-20

5. Koroleva, S.V. Immunological assessment of breeding material when creating F1 hybrids of white cabbage with group 
resistance to fusarium and vascular bacteriosis/ S.V. Koroleva, S.A. Dyakunchak, S.V.Sitnikov (guidelines) - Moscow, 2012.-16 p.

6. Mazurin, E.S. Assessment of strain variety of blac rot pathogen cabbage / E.S. Mazurin, A.N. Ignatov, E.V. Matveeva, F.S. Jalilov // News TCXA. - 2010. - Exh. 5. - P.86-93. (In Russ.)

7. Monakhos, G.F. Selection of cabbage for resistance: state and prospects / G.F.Monakhos, S. G. Monakhos, G. A. Kostenko // Potatoes and vegetables. - 2016. - №. 12. - P. 31-35.

8. Sukhorukova, N.S. Method for assessment and selection of white cabbage for resistance to vascular bacteriosis. Author's abstract. diss. Cand. s.-kh. sciences.-M., 1987.-16 p.

9. Ignatov, A. N. Vascular bacteriosis of cabbage in Russia - causes of epiphytoty, methods of protection and sources of selection for disease resistance / A. N. Ignatov, S. V. Panchuk, Vo Thingok Kha, E. S. Mazurin, K. A. Kromina, F.S., Dzhamilov // Potatoes and vegetables. - 2016. - № 2. - P. 25.

10. Vicente, J. Identification and origin of Xanthomonas campestris races and related palhovars / J. Vicente // Phytopathology. - 2001. - 91. - P. 492-499.

\section{Королева Светлана Викторовна} Заведующая отделом овощеводства, ведущий научный сотрудник

E-mail: agrotransfer@mail.ru

\section{Дякунчак Светлана Александровна Ведущий научный сотрудник}

\section{Полякова Нелли Владимировна}

Младший научный сотрудник

Пистун Ольга Геннадьевна

Младший научный сотрудник

Bce: ФГБНУ «ФНЦ риса»

350921, Россия, г. Краснодар, Белозерный, 3

\section{Koroleva Svetlana Viktorovna}

Head of Vegeculture Growing Department, Leading Researcher

E-mail: agrotransfer@mail.ru

\section{Dyakunchak Svetlana Aleksandrovna} Leading Researcher

Polyakova Nelli Vladimirovna Junior Researcher of Vegeculture Growing Department

\section{Pistun Olga Gennadievna}

Junior Researcher of Vegeculture Growing Department

All: FSBSI «FSC of rice» Belozerny, 3, Krasnodar, 350921, Russia 


\section{ИЗУЧЕНИЕ КОМБИНАЦИОННОЙ СПОСОБНОСТИ ЛИНИЙ ТОМАТА ПО ПРИЗНАКАМ ПРОДУКТИВНОСТИ И ЕЕ СОСТАВЛЯЮЩИМ}

Основой эффективного селекционного процесса является генетический анализ наследования признаков, что позволяет производить отбор исходного материала и формировать оптимальную схему создания гибридов. Главным критерием для оценки количественных признаков родительских линий является комбинационная способность. В связи с этим целью исследований стало изучение комбинирующей способности по продуктивности и ее составляющим 5 материнских линий томата с функциональной мужской стерильностью и 6 линий-тестеров (опылителей) с последующим отбором лучших родителей и дальнейшим использованием их в создании гетерозисных гибридов. С использованием методов классической селекции, руководствуясь методикой оценки двух генетически разнокачественных наборов родительских линий, предложенной В.К. Савченко, получены результаты по определению комбинационной способности линий по признакам: «продуктивность растения», «средняя масса плода» и «количество плодов на растении». Определены эффекты общей и специфической комбинационной способности исследуемого материала. Выявлены наиболее перспективные линии для дальнейшей селекционной работы по созданию новых высокопродуктивных отечественных гибридов томата. Материнская линия Cu1-36(8) и тестеры ЛГ-1212/11 и ЛГ-1174/09 показали максимальные положительные эффекты ОКС по признакам продуктивности и количеству плодов на растении. Результаты, полученные в 2020 г., показали, что наиболее продуктивные гибриды (Сu1-36(8)хЛГ-1174/09, St543хЛГ-1174/09, Сф04(19)хЛГ-1174/09 и St644xЛГ-1212/11) получены с участием отцовских линий, имеющих высокое значение ОКС. На среднюю массу плода большее влияние оказывают комбинационные способности материнских линий. Эффекты СКС в данных комбинациях высокие и средние.

Ключевые слова: томат, линии, гибриды, комбинирующая способность, продуктивность, OKC, CKC.

\section{STUDY OF TOMATO LINES COMBINING ABILTY BY PRODUCTIVITY AND ITS COMPONENTS}

The basis of an effective breeding process is the genetic analysis of the inheritance of traits, which allows you to correctly select the source material and form the optimal scheme for developing hybrids. The main criterion for assessing the quantitative traits of parental lines is the combining ability. In this regard, the aim of the research was to study the combining ability for productivity and its components of 5 maternal lines of tomato with functional male sterility and 6 lines of testers (pollinators), followed by the selection of the best parents and their further use in developing heterotic hybrids. Using the methods of classical breeding, guided by the methodology for evaluating two genetically different sets of parental lines proposed by V.K. Savchenko, the results were obtained to determine the combining ability of the lines according to the traits: plant productivity, average fruit weight and the number of fruits per plant. The effects of the total and specific combining ability of the material under study were determined. The most promising lines for further breeding work on development of new highly productive domestic tomato hybrids have been identified. Maternal line Cu1-36 (8) and testers LG-1212/11 and LG-1174/09 showed the maximum positive effects of TCA in terms of productivity and the number of fruits per plant. The results obtained in 2020 showed that the most productive hybrids (Cu1-36 (8) xLG-1174/09, St543xLG-1174/09, Sf04 (19) xLG-1174/09 and St644xLG-1212/11) were obtained with the participation of paternal lines with a high TCA value. The average weight of the fruit is more influenced by the combining abilities of the maternal lines. SCA effects in these combinations are high and medium.

Key words: tomato, lines, hybrids, combining ability, productivity, TCA, SCA.

\section{Введение}

Основной целью в стратегии развития сельского хозяйства является обеспечение продовольственной безопасности Российской Федерации. В свете решений правительства по импортозамещению ставится задача обеспечить население отечественной овощной продукцией не менее чем на 85 - $90 \%$ [1]. Овощеводство одна из важных и перспективных отраслей в Краснодарском крае. В связи с политическими и экономическим процессами в мире в минувшие пять - семь лет, введением экономических санкций в регионе реализуется программа по импортозамещению в сфере производства сельскохозяйственной продукции, в том числе и для овощеводства.

Томат - одна из самых распространенных овощных культур. В мире помидоры выращивают в 170 странах на площади 4,7 млн. гектаров с общим 
объемом производства 159 млн. тонн. В настоящее время Россия занимает 8-е место в мире по производству томатов. Урожай этой культуры составляет около 1 млн. тонн в год [13]. В Краснодарском крае под томатом открытого грунта занято 0,58 тыс. га (3,3 \% площадей). Валовый сбор составляет 17,26 тыс. тонн. Это 1,8 \% общего сбора по стране [14].

По сравнению со многими овощными культурами, томат для России - культура относительно новая. Выращивать томаты начали в южных районах страны в XVIII веке. Одна из первых публикаций об этой культуре в России принадлежит основоположнику российской агрономии, ученому и исследователю Андрею Тимофеевичу Болотову. K середине XIX века культура томатов начала распространяться по огородам России в средних областяX, а к концу XIX столетия широко распространилась и в северных районах страны [12].

В последние годы сортимент томата в России значительно расширился. Сложные современные экономические условия, большая конкуренция с импортными сортами на рынке семян предъявляют новые требования к отечественному сортименту томата. Требуются новые сорта и гибриды с повышенной потенциальной урожайностью и устойчивостью к стрессовым факторам среды для различных технологий возделывания. Гибриды обладают значительным преимуществом перед линейными сортами по продуктивности растений, выравненности плодов, товарным качествам, дружной отдаче урожая и другим признакам [16]. Они более устойчивы к неблагоприятным и стрессовым погодным условиям, лучше сохраняют генеративные органы в процессе роста и развития и по этой причине имеют большее число плодов, обладают повышенной резистентностью к болезням и вирусам [7].

Основой эффективного селекционного процесса является генетический анализ наследования признаков, что позволяет правильно выбирать исходный материал и формировать оптимальную схему создания гибридов. Обязательное звено селекционного процесса - оценка комбинационной способности. [6, 18]. Для определения генотипа отселектированных линий применяют методику по оценке комбинационной способности, которая позволяет оценить возможность биотипов давать гетерозисное потомство при скрещивании с другими особями или сортами [15].

Семеноводство гибридов требует больших затрат ручного труда для изоляции, кастрации и маркировки цветков. В связи с этим, себестоимость гибридных семян очень высока. Использование линий с признаком стерильности в качестве материнских компонентов позволяет сократить время на производство гибридных семян и вдвое снизить затраты труда на опыление [2].

\section{Цель исследований}

Определить ценность отселектированных линий томата путем изучения их комбинационной способности по признакам продуктивности. Выделить перспективные родительские линии для дальнейшего использования их в создании гетерозисных гибридов.

\section{Материалы и методы}

Исследования проводили в 2020 г. на опытных участках отдела овощеводства «ФНЦ риса». Гибридизация проведена в 2019 году. При создании гибридов томата на основе функциональной мужской стерильности наиболее приемлемым является метод оценки комбинационной способности двух генетически разнокачественных наборов родительских линий, предложенный В. К. Савченко [10]. Схема скрещиваний проводится в одном направлении, когда материнскими линиями выступают стерильные, а отцовскими - фертильные особи. Данная схема, в отличие от топкросса, позволяет определить не только общую комбинационную способность родительских линей, но и специфические для каждой комбинации эффекты комбинационной способности.

В схему гибридизации было взято 5 стерильных материнских линий томата с признаком ФМС (функциональная мужская стерильность) селекции ООО «Селекционная станция им. Н.Н. Тимофеева» МСХА и 6 отцовских сортов-опылителей селекции «ФНЦ риса». В результате скрещивания было получено 30 гибридов. Работу проводили в соответствии с «Методическими указаниями по селекции сортов и гибридов томата для открытого и защищенного грунта» [3]. Учеты и наблюдения по «Методике опытного дела в овощеводстве» [9]. Результаты исследований обработаны методами биометрической статистики [5, 11]. Рассаду гибридов выращивали по кассетной технологии [4]. Посев семян в кассеты проводили 19 марта. Высадку рассады в поле - 28 апреля по схеме $(90+50)$ х 35 см. Размещение делянок - систематическое. Повторность 3-х кратная, количество растений на делянку 20 шт., учетная площадь делянки - 7 кв. м. Полив: капельное орошение. Предшественник тыквенные культуры. В течение вегетационного периода проводили фенологические наблюдения, биометрические измерения растений. Уборка урожая - вручную поделяночно весовым методом по мере созревания плодов.

\section{Результаты и обсуждение}

Для оценки комбинационной способности 5-ти стерильных и 6-ти линий-тестеров (опылителей) в 2019 году применили схему скрещивания двух генетически разнокачественных наборов родительских линий, предложенный В. К. Савченко [10]. В результате чего получили 30 гибридов, продуктивные признаки которых оценивали в 2020 г. Продуктивность гибридов томата определяли по резуль- 
татам 2-х сборов. Варьирование данного признака наблюдалось в пределах от 0,81 кг/растение до 2,26 кг/растение (табл. 1). Наибольшей продуктивностью обладали гибриды: Cu1-36(8) х ЛГ-1174/09 (2,19 кг/растение), St543 x ЛГ-1174/09 (2,26 кг/растение), Сф04(19) х ЛГ-1174/09 (2,21 кг/растение) и St644 x ЛГ-1212/11 (2,19 кг/растение). Среди линий самые высокие значения продуктивности были показаны материнской линией Cu1-36(8) и линиями-тестерами ЛГ-1212/11 и ЛГ-1174/09, средние значения - линиями St543, Cф04(19) и ЛГ-1213/112, низкую среднюю продуктивность показали материнская линия St644 и линии-тестеры Лh-863/09, Вepa, 819-341.

Таблица 1. Продуктивность гибридов (кг/растение), 2020 г.

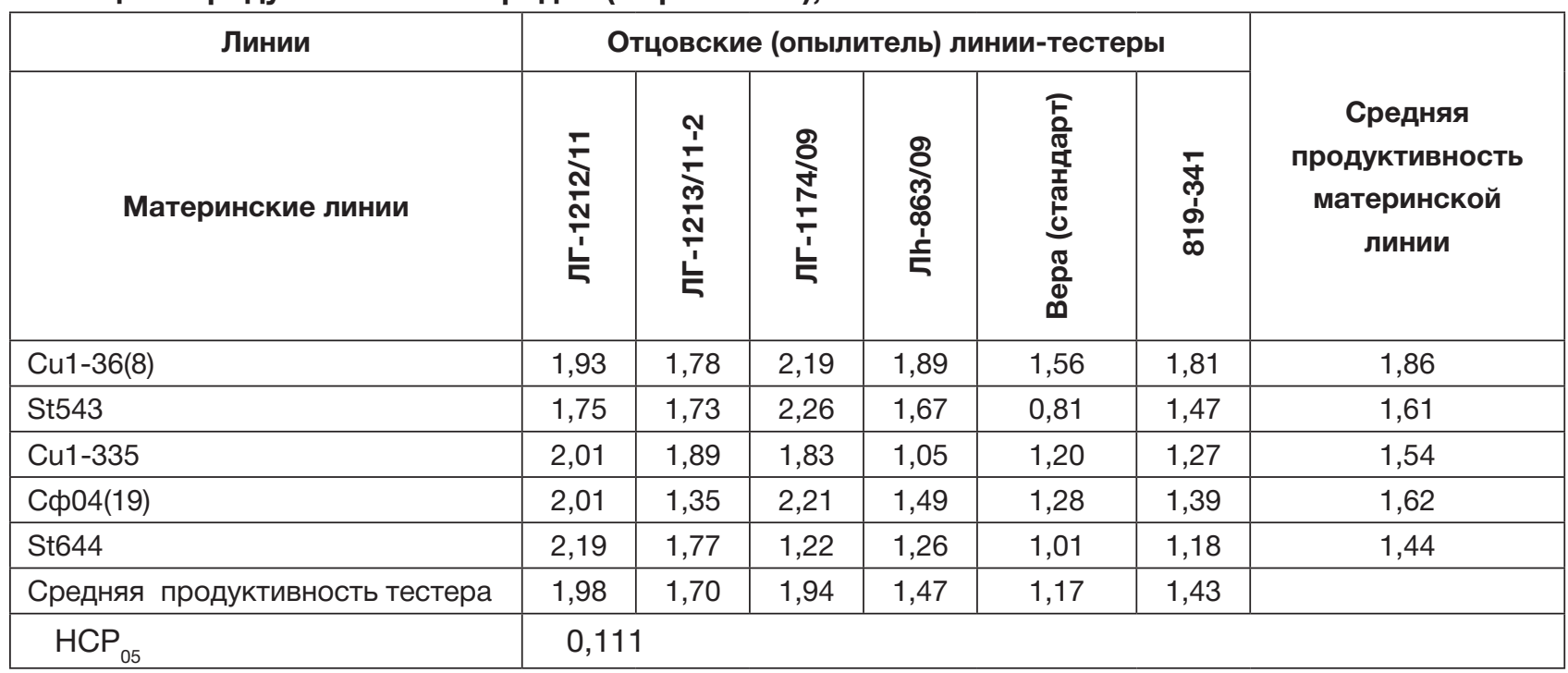

Оценка общей комбинационной способности (OKC) дает важную информацию для использования генетического потенциала родителей поскольку дисперсия значимых и высоких эффектов ОКС родительской линии отражает наличие благоприятных аддитивных генов. Это дает возможность отобрать на начальном этапе линии для создания адаптированных гибридов.

Оценка эффектов ОКС по признаку продуктивности и ее составляющим показала, что среди материнских линий их положительные значения по всем показателям были только у линии $\mathrm{Cu}$ 1-36(8) (табл. 2).

По массе плода наибольшее положительное значения ОКС показала линия Сф04(19). Но у этой линии было отрицательное значение ОКС по признаку «количество плодов на растении» и средние по «продуктивности».

Среди тестеров ни один не имел положительные эффекты ОКС по всем признакам. По продуктивности выделились ЛГ-1212/11 и ЛГ-1174/09, но они имели низкие показатели по массе плода и высокие по их количеству на растении. Линия-опылитель ЛГ-1213/11-2 показала высокие общие комбинационные способности по средней массе плода, средние по продуктивности и количеству плодов на растении. Наихудшим комбинатором, имеющим отрицательные значения ОКС по всем признакам, оказался тестер Вера.

Согласно результатам, материнская линия Cu 1-36(8) и тестеры ЛГ-1212/11 и ЛГ-1174/09 показали максимальные положительные эффекты OKC по признакам продуктивности и количеству плодов на растении. Эти родители могут быть успешно использованы в будущих селекционных программах при создании высокопродуктивных гибридов со средними плодами. А линии Сф04(19) и ЛГ-1213/11-2, имеющие максимальные значения ОКС по массе плода и положительные средние показатели по продуктивности, при создании крупноплодных гибридов средней урожайности.

Таблица 2. Эффекты ОКС линий по признаку продуктивности и ее составляющим

\begin{tabular}{|c|c|c|c|c|}
\hline \multicolumn{2}{|c|}{$\begin{array}{c}\text { Родительские } \\
\text { линии }\end{array}$} & $\begin{array}{c}\text { ОКС по } \\
\text { продуктивности }\end{array}$ & $\begin{array}{c}\text { ОКС по массе } \\
\text { плода }\end{array}$ & $\begin{array}{c}\text { ОКС по количеству } \\
\text { плодов на растении }\end{array}$ \\
\hline \multirow{3}{*}{ Материнские линии } & Cu 1-36(8) & 0,246 & 1,47 & 1,73 \\
\cline { 2 - 5 } & St 543 & $-0,001$ & $-3,86$ & 0,18 \\
\cline { 2 - 5 } & Cu 1-335 & $-0,074$ & $-9,73$ & 0,01 \\
\cline { 2 - 5 } & Cф04(19) & 0,006 & 11,60 & $-1,28$ \\
\cline { 2 - 5 } & St 644 & $-0,177$ & 0,51 & $-1,34$ \\
\hline
\end{tabular}


Продолжение таблицы 2

\begin{tabular}{|c|c|c|c|c|}
\hline \multicolumn{2}{|c|}{$\begin{array}{c}\text { Родительские } \\
\text { линии }\end{array}$} & $\begin{array}{c}\text { ОКС по } \\
\text { продуктивности }\end{array}$ & $\begin{array}{c}\text { ОКС по массе } \\
\text { плода }\end{array}$ & $\begin{array}{c}\text { ОКС по количеству } \\
\text { плодов на растении }\end{array}$ \\
\hline \multirow{4}{*}{ Тестеры } & ЛГ-1212/11 & 0,361 & $-7,17$ & 4,13 \\
\cline { 2 - 5 } & ЛГ-1213/11-2 & 0,089 & 8,26 & $-0,19$ \\
\cline { 2 - 5 } & ЛГ-1174/09 & 0,327 & $-5,84$ & 3,46 \\
\cline { 2 - 5 } & Лh-863/09 & $-0,146$ & 7,81 & $-2,07$ \\
\cline { 2 - 5 } & Bepa & $-0,443$ & $-10,29$ & $-2,86$ \\
\cline { 2 - 5 } & $819-341$ & $-0,189$ & 7,21 & $-2,47$ \\
\hline
\end{tabular}

О характере поведения линий в отдельных комбинациях скрещивания можно судить по вариансам констант СКС. Низкие вариансы означают, что линия устойчиво передает признаки гибридам, а высокие вариансы - что признак может иметь в одних комбинациях более высокое значение, чем в других [8]. В опыте по признаку «продуктивность» низкие вариансы $(0,04)$ имеют материнские линии Cu 1-36(8), Cu 1-335 и Cф04(19), а так же тестеры 819-341 и Вера (0,01 и 0,04 соответственно) (табл. 3). Высокие вариансы по этому признаку - у стерильной линии St $644(0,1)$ и у опылителя ЛГ-1174/09 (0,12). Остальные линии имели средние значения варианс.

Таблица 3. Результаты оценки продуктивности гибридов по эффектам СКС и родительских линий по вариансам, 2020 г.

\begin{tabular}{|c|c|c|c|c|c|c|c|}
\hline \multirow{2}{*}{$\begin{array}{c}\text { Родительские } \\
\text { линии } \\
\text { Материнские } \\
\text { линии }\end{array}$} & \multicolumn{6}{|c|}{ Отцовские (опылитель) линии-тесторы } & \multirow{2}{*}{ Варианса } \\
\hline & ЛГ-1212/11 & лГ-1213/11-2 & лГ-1174/09 & Лh-863/09 & Bepa & $819-341$ & \\
\hline Cu 1-36(8) & $-0,29$ & $-0,17$ & $-0,01$ & 0,17 & 0,14 & 0,14 & 0,04 \\
\hline St 543 & $-0,23$ & 0,03 & 0,32 & 0,20 & $-0,37$ & 0,05 & 0,07 \\
\hline Cu 1-335 & 0,11 & 0,26 & 0,04 & $-0,34$ & 0,10 & $-0,08$ & 0,04 \\
\hline Сф04(19) & 0,02 & $-0,36$ & 0,26 & $-0,01$ & 0,10 & $-0,04$ & 0,04 \\
\hline St 644 & 0,39 & 0,24 & $-0,54$ & $-0,04$ & 0,02 & $-0,07$ & 0,1 \\
\hline варианса & 0,08 & 0,07 & 0,12 & 0,05 & 0,04 & 0,01 & \\
\hline
\end{tabular}

Проанализировав самые высокопродуктивные комбинации с точки зрения ОКС родительских линий, участвующих в скрещивании, и СКС полученных гибридов, а так же среднюю массу плода и их количество на растении, можно отметить следующую закономерность: наиболее продуктивные гибриды получены с участием отцовских особей, имеющих
Специфические эффекты комбинирующей способности представляют собой доминирующие и эпистатические эффекты генов, которые могут быть использованы в качестве индекса для определения полезности конкретной комбинации [17]. СКС является показателем в большей части доминантного типа действия генов. Эффекты СКС по продуктивности в комбинациях скрещивания имели большой размах варьирования от - 0,54 до +0,39. Наибольшие положительные эффекты CKC $(0,24-0,39)$ проявили комбинация Cu1-36(8) x Лh-863/09, Cu1-335 x ЛГ-1213/11-2, Сф04(19) x ЛГ-1174/09, St644 х ЛГ-1213/11-2 и St644 х ЛГ$1212 / 11$

Таблица 4. Результаты оценки ОКС родительских линий томата по признакам в высокопродуктивных комбинациях.

\begin{tabular}{|c|c|c|c|c|c|c|c|c|c|c|}
\hline \multirow[t]{2}{*}{ Комбинация } & \multirow{2}{*}{$\begin{array}{c}\text { Про- } \\
\text { дуктив- } \\
\text { ность, } \\
\text { кг/раст. }\end{array}$} & \multicolumn{2}{|c|}{$\begin{array}{c}\text { ОКс } \\
\text { родительских } \\
\text { линий } \\
\end{array}$} & \multirow{2}{*}{$\begin{array}{c}\text { СКС } \\
\text { комби- } \\
\text { нации }\end{array}$} & \multirow{2}{*}{$\begin{array}{l}\text { Масса } \\
\text { плода }\end{array}$} & \multicolumn{2}{|c|}{$\begin{array}{c}\text { OКС роди- } \\
\text { тельских } \\
\text { линий }\end{array}$} & \multirow{2}{*}{$\begin{array}{l}\text { Количе- } \\
\text { ство пло- } \\
\text { дов на } \\
\text { растении, } \\
\text { шт } \\
\end{array}$} & \multicolumn{2}{|c|}{$\begin{array}{c}\text { ОКс } \\
\text { родительских } \\
\text { линий }\end{array}$} \\
\hline & & 우 & $\hat{0}$ & & & 우 & $\hat{\delta}$ & & q & $\widehat{\sigma}$ \\
\hline $\begin{array}{c}\text { Cu1-36(8)x } \\
Л Г-1174 / 09\end{array}$ & 2,19 & $\begin{array}{c}\text { высо- } \\
\text { кая }\end{array}$ & $\begin{array}{c}\text { высо- } \\
\text { кая }\end{array}$ & $-0,01$ & 113,5 & $\begin{array}{c}\text { сред- } \\
\text { няя }\end{array}$ & $\begin{array}{l}\text { низ- } \\
\text { кая }\end{array}$ & 19,26 & $\begin{array}{c}\text { высо- } \\
\text { кая }\end{array}$ & $\begin{array}{c}\text { высо- } \\
\text { кая }\end{array}$ \\
\hline $\begin{array}{c}\text { St543хЛГ- } \\
1174 / 09\end{array}$ & 2,26 & $\begin{array}{c}\text { сред- } \\
\text { няя }\end{array}$ & $\begin{array}{c}\text { высо- } \\
\text { кая }\end{array}$ & 0,32 & 116,0 & $\begin{array}{c}\text { сред- } \\
\text { няя }\end{array}$ & $\begin{array}{l}\text { низ- } \\
\text { кая }\end{array}$ & 19,51 & $\begin{array}{c}\text { сред- } \\
\text { няя }\end{array}$ & $\begin{array}{c}\text { высо- } \\
\text { кая }\end{array}$ \\
\hline
\end{tabular}


Продолжение таблицы 4

\begin{tabular}{|c|c|c|c|c|c|c|c|c|c|c|}
\hline \multirow[t]{2}{*}{ Комбинация } & \multirow{2}{*}{$\begin{array}{c}\text { Про- } \\
\text { дуктив- } \\
\text { ность, } \\
\text { кг/раст. }\end{array}$} & \multicolumn{2}{|c|}{$\begin{array}{c}\text { OKс } \\
\text { родительских } \\
\text { линий }\end{array}$} & \multirow{2}{*}{$\begin{array}{c}\text { СКС } \\
\text { комби- } \\
\text { нации }\end{array}$} & \multirow{2}{*}{$\begin{array}{c}\text { Масса } \\
\text { плода }\end{array}$} & \multicolumn{2}{|c|}{$\begin{array}{c}\text { ОКс роди- } \\
\text { тельских } \\
\text { линий } \\
\end{array}$} & \multirow{2}{*}{$\begin{array}{c}\text { Количе- } \\
\text { ство пло- } \\
\text { дов на } \\
\text { растении, } \\
\text { шт }\end{array}$} & \multicolumn{2}{|c|}{$\begin{array}{c}\text { ОКс } \\
\text { родительских } \\
\text { линий }\end{array}$} \\
\hline & & 우 & $\hat{0}$ & & & 우 & $\sigma^{\lambda}$ & & 우 & $\delta$ \\
\hline $\begin{array}{c}\text { Сф04(19) } \\
\text { хЛГ-1174/09 } \\
\end{array}$ & 2,21 & $\begin{array}{c}\text { сред- } \\
\text { няя }\end{array}$ & $\begin{array}{c}\text { высо- } \\
\text { кая }\end{array}$ & 0,26 & 126,0 & $\begin{array}{c}\text { высо- } \\
\text { кая }\end{array}$ & $\begin{array}{l}\text { низ- } \\
\text { кая }\end{array}$ & 17,54 & низкая & $\begin{array}{c}\text { высо- } \\
\text { кая }\end{array}$ \\
\hline $\begin{array}{c}\text { St644хЛГ- } \\
\text { 1212/11 }\end{array}$ & 2,19 & низкая & $\begin{array}{c}\text { высо- } \\
\text { кая }\end{array}$ & 0,39 & 96,0 & $\begin{array}{c}\text { низ- } \\
\text { кая }\end{array}$ & $\begin{array}{l}\text { низ- } \\
\text { кая }\end{array}$ & 22,82 & низкая & $\begin{array}{c}\text { высо- } \\
\text { кая }\end{array}$ \\
\hline $\begin{array}{c}\text { Cu 1-335x } \\
1212 / 11 \\
\end{array}$ & 2,01 & низкая & $\begin{array}{c}\text { высо- } \\
\text { кая }\end{array}$ & 0,11 & 111,1 & $\begin{array}{l}\text { низ- } \\
\text { кая }\end{array}$ & $\begin{array}{l}\text { низ- } \\
\text { кая }\end{array}$ & 18,07 & $\begin{array}{c}\text { сред- } \\
\text { няя }\end{array}$ & $\begin{array}{c}\text { высо- } \\
\text { кая }\end{array}$ \\
\hline $\begin{array}{c}\text { Сф04(19)x } \\
1212 / 11\end{array}$ & 2,01 & $\begin{array}{c}\text { сред- } \\
\text { няя }\end{array}$ & $\begin{array}{c}\text { высо- } \\
\text { кая }\end{array}$ & 0,02 & 123,0 & $\begin{array}{c}\text { высо- } \\
\text { кая }\end{array}$ & $\begin{array}{l}\text { низ- } \\
\text { кая }\end{array}$ & 16,3 & низкая & $\begin{array}{c}\text { высо- } \\
\text { кая }\end{array}$ \\
\hline $\mathrm{HCP}_{05}$ & 0,111 & & & & 5,21 & & & 1,83 & & \\
\hline
\end{tabular}

\section{Выводы}

В ходе исследований установлено, что признак «продуктивность томата» контролируется полигенной системой. Наибольшей продуктивностью обладали гибриды: Cu1-36(8) x ЛГ-1174/09, St543 x ЛГ-1174/09, Сф04(19) х ЛГ-1174/09 и St644 х ЛГ1212/11.

Материнская линия Cu1-36(8) и тестеры ЛГ1212/11 и ЛГ-1174/09 показали максимальные положительные эффекты ОКС по признакам «продуктивность» и «количество плодов на растении». Эти родители могут быть успешно использованы в будущих селекционных программах при создании высокопродуктивных гибридов со средними плодами. А линии Сф04(19) и ЛГ-1213/11-2 при создании крупноплодных гибридов средней урожайности.

Наиболее продуктивные гибриды получены с участием отцовских линий, имеющих высокое значение ОКС. На среднюю массу плода большее влияние оказывают комбинационные способности материнских линий. Эффекты СКС в данных комбинациях высокие и средние.

При селекции томата на высокопродуктивные крупноплодные гибриды салатного назначения целесообразно в качестве материнских использовать стерильные линии, обладающие высокой OKC по признаку «масса плода», а в качестве опылителей - формы с высокой комбинационной способностью по признакам «продуктивность» и «количество плодов на растении».

\section{ЛИТЕРАТУРА}

1. Распоряжение Правительства РФ от 17 ноября 2008 г. № 1662-р. О Концепции долгосрочного социальноэкономического развития РФ (с изменениями и дополнениями) / Система ГАРАНТ: http: / base. garant. ru / 194365.

2. Авдеев, А.Ю. Метод селекции томатов с малиновыми плодами, устойчивыми к растрескиванию: Селекция, семеноводство и технология выращивания овощных, бахчевых, технических и кормовых культур. / А.Ю. Авдеев, О.П. Кигашпаева, Ю.И. Авдеев. - Астрахань, 2014. - № 1(1). - С. 147 - 150.

3. Алпатьев, А. В. и др. Методические указания по селекции сортов и гибридов томата для открытого и защищенного грунта. - М.: Колос, 1986.- 64 с.

4. Грушанин, А.И. Технология выращивания томата в открытом грунте на Кубани: рекомендации / А.И. Грушанин, Л.В. Есаулова, и др. - Краснодар, 2016. - 36 с.

5. Дзюба, В.А. Многофакторные опыты и методы биометрического анализа экспериментальных данных: Методическое пособие / В.А. Дзюба. - Краснодар, 2007.- 76 с.

6. Кильчевский, А.В. Генетические основы селекции томата на гетерозис: Молекулярная и прикладная генетика / А.В. Кильчевский и др. - Минск, 2008. - Т. 8. - С. 25-39

7. Козлова, И.В. Создание новых стерильных линий томата с ценными хозяйственными признаками в условиях юга России / И.В. Козлова // Известия ФНЦО. - М.: ООО «ТР-принТ», 2020. - № 2. - С. 43-48

8. Королева, С.В. Комбинационная способность перспективных линий перца сладкого по признакам продуктивности / С.В. Королева, Н.В. Шуляк // Рисоводство.- Краснодар, 2019. - №4(45). - С. 58-63

9. Литвинов, С.С. Методика опытного дела в овощеводстве / С.С. Литвинов. - М., 2011. - 648 с.

10. Савченко, В. К. Метод оценки комбинационной способности генетически разнокачественных наборов родительских форм: Методика генетико-селекционного и генетического эксперимента / В. К Савченко. - Минск, 1973. - С. 48 - 77

11. Шеуджен, А.Х. Методика агрохимических исследований и статистическая оценка их результатов / А.Х. Шеуджен, Т.Н. Бондарева. - Майкоп: ОАО «Полиграф-ЮГ», 2015. - 664 с.

12. История происхождения томатов [Электронный ресурс]. - Режим доступа: https://cyberlesson.ru/kogda-vrossii-pojavilis-pomidory

13. Обзор рынка томатов в России. [Электронный ресурс]. - Режим доступа: https://www.openbusiness.ru/biz/ business/obzor-rynka-tomatov-v-rossii

14. Помидоры открытого грунта: площади и сборы в России в 2001-2019 гг. [Электронный ресурс]. - Режим доступа: 
https://agrovesti.net/lib/industries/vegetables/pomidory-otkrytogo-grunta-ploshchadi-i-sbory-v-rossii-v-2001-2019-gg.html

15. Aisya, S. I. The estimation of combining ability and heterosis effect for yield and yield components in tomato (Lycopersicon esculentum Mill.) at lowland / S. I. Aisya et al. //Ekin Journal of crop breeding and genetics, 2016. - V. 2. - №. 1 - P. $23-29$.

16. Chishti, S. A. Analysis of combining ability for yield, yield components and quality characters in tomato (Lycopersicon esculentum Mill.)/ S. A. Chishti et al. //J. Agric. Res, 2008. - V. 46. - № 4. - P. 325-332.

17. Kumar R. et al. Combining ability analysis for yield and quality traits in tomato (Solanum lycopersicum L.) //Journal of Agricultural Science, 2013. - V. 5. - № 2. - P. 213-216

18. Saeed, A. Genetic analysis to find suitable parents for development of tomato hybrids / A. Saeed et al. //Life Sci J, 2014. - V. 11. - № 12s. - P. 30-35.

\section{REFERENCES}

1. Order of the Government of the Russian Federation dated November 17, 2008. - №. 1662-r. About the Concept of long-term socio-economic development of the Russian Federation (with amendments and additions) / GARANT system: http: / base. garant. ru / 194365

2. Avdeev, A. Yu. Breeding method for tomatoes with cracking resistant purple fruits: Breeding, seed production and technology for growing vegetables, melons, industrial and forage crops. / A.Yu. Avdeev, O. P. Kigashpaeva, Yu.I. Avdeev. Astrakhan, 2014. - № 1 (1). - P. 147 - 150.

3. Alpat'ev, A. V. et al. Guidelines for breeding of tomato varieties and hybrids for open and protected ground. - M .: Kolos, 1986. - 64 p.

4. Grushanin, A.I. Technology for growing tomatoes in open ground in the Kuban: recommendations / A.I. Grushanin, L.V. Esaulova, et al. - Krasnodar, 2016. - 36 p.

5. Dzyuba, V.A. Multifactorial experiments and methods of biometric analysis of experimental data: Methodological manual / V.A. Dzyuba. - Krasnodar, 2007. - 76 p.

6. Kilchevsky, A.V. Genetic bases of tomato breeding for heterosis: Molecular and Applied Genetics / A.V. Kilchevsky et al. - Minsk, 2008. - V. 8. - P. 25-39

7. Kozlova, I. V. Development of new sterile tomato lines with economically valuable traits in the conditions of the south of Russia / I.V. Kozlova // Izvestiya FNTSO. - M.: OOO “TR-print”, 2020. - № 2. - P. 43-48

8. Koroleva, S.V. Combining ability of promising lines of sweet pepper in terms of productivity / S.V. Koroleva, N.V. Shulyak // Rice growing. - Krasnodar, 2019. - №4 (45). - P. 58-63

9. Litvinov, S.S. Experimental methodology in vegetable growing / S.S. Litvinov. - M., 2011.- 648 p.

10. Savchenko, V.K. Method for assessing the combining ability of genetically diverse sets of parental forms: Methodology of genetic-breeding and genetic experiment / V.K Savchenko. - Minsk, 1973. - P. 48 - 77

11. Sheudzhen, A.Kh. Agrochemical research methods and statistical evaluation of their results / A.Kh. Sheudzhen, T.N. Bondareva. - Maykop: OJSC Polygraph-YUG, 2015. - 664 p.

12. The history of the origin of tomatoes [Electronic resource]. - Access mode: https://cyberlesson.ru/kogda-v-rossii-pojavilis-pomidory

13. Review of the tomato market in Russia. [Electronic resource]. - Access mode: https://www.openbusiness.ru/biz/ business/obzor-rynka-tomatov-v-rossii

14. Open ground tomatoes: areas and yields in Russia in 2001-2019 [Electronic resource]. - Access mode: https:// agrovesti.net/lib/industries/vegetables/pomidory-otkrytogo-grunta-ploshchadi-i-sbory-v-rossii-v-2001-2019-gg.html

15. Aisya, S. I. The estimation of combining ability and heterosis effect for yield and yield components in tomato (Lycopersicon esculentum Mill.) at lowland / S. I. Aisya et al. //Ekin Journal of crop breeding and genetics, 2016. - V. 2. - № 1. - P. 23-29.

16. Chishti, S. A. Analysis of combining ability for yield, yield components and quality characters in tomato (Lycopersicon esculentum Mill.)/ S. A. Chishti et al. //J. Agric. Res, 2008. - V. 46. - № 4. - P. 325-332.

17. Kumar, R. et al. Combining ability analysis for yield and quality traits in tomato (Solanum lycopersicum L.) //Journal of Agricultural Science, 2013. - V. 5. - № 2. - P. 213-216.

18. Saeed, A. Genetic analysis to find suitable parents for development of tomato hybrids / A. Saeed et al. //Life Sci J, 2014. - V. 11. - № 12. - P. 30 - 35.

\section{Козлова Ирина Викторовна}

Научный сотрудник отдела

овощекартофелеводства

E-mail: k.irina1967@mail.ru

ФГБНУ «ФНЦ риса», 350921, Краснодар, пос. Белозерный 3

\section{Kozlova Irina Viktorovna}

Research associate of the Department

vegetable and potato growing

E-mail: k.irina1967@mail.ru

FSBSI «FSC of rice»

3, Belozerny, Krasnodar, 350921, Russia 


\section{ВЛИЯНИЕ ОРГАНОМИНЕРАЛЬНЫХ УДОБРЕНИЙ НА УРОЖАЙНОСТЬ РОДИТЕЛЬСКИХ ФОРМ ГИБРИДА КУКУРУЗЫ КРАСНОДАРСКИЙ 291 АМВ}

За последние годы в Краснодарском ФГБНУ «НЦЗ им. П.П. Лукьяненко» созданы высокотехнологичные, конкурентоспособные, высокоурожайные гибриды кукурузы с быстрой отдачей влаги зерном при созревании. Представителем таких групп гибридов является среднеранний модифицированный Краснодарский 291 АМВ. Стабильность этого гибрида кукурузы позволяет ему занимать большие площади посева в Краснодарском крае и по всему Северо-Кавказскому региону. Кроме того, эти семена реализуются в других регионах нашей страны и естественно возрастает реальная потребность в большем количестве этих гибридов для широкой реализации. Высокая продуктивность растений кукурузы должна быть обусловлена оптимальными сочетаниями всего комплекса внешних условий - водного, пищевого, температурного, светового, почвенного и ряда других. Кроме того, надо иметь ввиду и агробиологические особенности кукурузы, с тем чтобы рационально построить технологию ее возделывания. Рост урожайности семян первого поколения гибрида Краснодарский 291 AMВ обеспечен улучшением питательного режима путем подкормки в процессе вегетации органоминеральными удобрениями. Повышение коэффициента использования питательных веществ из почвы и внесенных удобрений, оптимизация микроэлементного питания, увеличили высоту растений на 6-8 см, площадь листовой поверхности на 1,7-2,4 тыс. м²/га и фотосинтетический потенциал на 90-153 тыс. м²/га, повысили зерновую продуктивность, пыльцеобразование отцовских растений для лучшего опыления при гибридизации, т.е. получение более высокого урожая качественных семян первого поколения.

Ключевые слова: кукуруза, листовая подкормка, органоминеральные удобрения, площадь листьев, высота стебля, масса 1000 зерен, урожайность зерна, гибридные семена.

\section{INFLUENCE OF ORGANOMINERAL FERTILIZERS ON THE YIELD OF PARENTAL FORMS OF THE MEDIUM-EARLY CORN HYBRID KRASNODAR 291 AMV}

In recent years in the Krasnodar Federal State Budget Scientific Institution "National Center of Grain named after P.P. Lukyanenko» created high-tech, competitive, high-yielding corn hybrids with a quick release of moisture from the grain during ripening. The representative of such groups of hybrids is the mid-early modified Krasnodar 291 AMV. The stability of this corn hybrid allows it to occupy large areas of crops in the Krasnodar Territory and throughout the North Caucasus region. In addition, these seeds are sold in other regions of our country, and naturally, the real need for more of these hybrids for widespread sale increases. The high productivity of maize plants should be due to the optimal combination of the entire complex of external conditions - water, food, temperature, light, soil, and a number of others. In addition, it is necessary to keep in mind the agrobiological characteristics of maize in order to rationally build a technology for its cultivation. The increase in the yield of seeds of the first generation of the Krasnodar 291 AMV hybrid is ensured by an improvement in the nutritional regime by feeding during the growing season with organomineral fertilizers. Increasing the utilization rate of nutrients from the soil and applied fertilizers, optimizing micronutrient nutrition, increased plant height by 6-8 cm, leaf surface area by 1.7-2.4 thousand $\mathrm{m} 2$ / ha and photosynthetic potential by 90-153 thousand $\mathrm{m} 2$ / ha, increased grain productivity, pollen formation of paternal plants for better pollination during hybridization, i.e. obtaining a higher yield of high-quality seeds of the first generation.

Key words: corn, foliar feeding, organomineral fertilizers, leaf area, stem height, mass of 1000 grains, grain yield, hybrid seeds.

\section{Введение}

Неотьемлемой частью выращивания высоких урожаев зерна кукурузы является оптимизация минерального питания растений. Применение большого количества минеральных удобрений в последнее время заменяется применением органоминеральных удобрений, которые используются небольшими дозами и при этом дают высокую эффективность, минуя негативные последствия на окружающую среду и обеспечивая ее экологичность $[7,12,13]$.

Рациональное использование органоминеральных удобрений для получения высоких урожаев гибридных семян кукурузы требует проработки вопроса в рамках изучения влияния их на повышение продуктивности материнских растений и пыльцевой продуктивности отцовских форм [3, 4, 5, 8, 9, 10]. 


\section{Цель исследований}

Повысить продуктивность гибридных семян первого поколения модифицированного гибрида Краснодарский 291 АМВ q Кр 640 УМ, а также повысить пыльцевую продуктивность отцовской формы §̊ Кр $244 \mathrm{MB}$.

\section{Материалы и методы}

Исследования проводили в центральной зоне восточной подзоне Краснодарского края в Гулькевичском районе в научно-производственном хозяйстве «Кубань» - филиале Федерального государственного бюджетного научного учреждения «Национальный центр зерна имени П.П. Лукьяненко» оригинатора простого модифицированного среднераннего гибрида Краснодарский 291 АМВ.

Материалом исследований были родительские формы среднераннего гибрида кукурузы Красно-

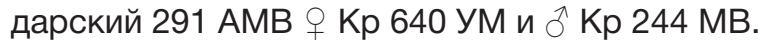

Материнская форма располагалась на шестивариантной схеме. В сравнении с контролем - без обработки (1. Вариант) изучали: 2. Batr Gum, 2 л/га, 3. Batr Gum 3 л/га, 4. Batr Max 2 л/га, 5. Batr Bor, 0,5 л/га и 6. Био Полимик, 1 л/га. Органоминеральные удобрения применяли методом опрыскивания растений в фазе 5-7 листьев.

Отцовские растения в фазе 5-7 листьев опрыскивали органоминеральными удобрениями на вариантах: 1. Контроль - без обработки; 2. Batr Bor, 0,5 л/га и 3. Био Полимик, 1 л/га.

Состав органоминеральных удобрений в:

Bater Bor г/л В - 131; Mo - 6,55; $\mathrm{SO}_{3}$ - 3,93; MgO 0,655; Zn - 0,262; Cu - 0,262; Fe - 0,393; Mn - 0,262.

Bater Gum г/л В - 1,998; Mo - 0,555; $\mathrm{SO}_{3}$ - 13,209; MgO - 1,935; Zn-0,555; Cu-0,555; Fe-0,222; Mn - 0,555.

Bater Max г/л N - 64,5; $\mathrm{P}_{2} \mathrm{O}_{5}-77,4 ; \mathrm{K}_{2} \mathrm{O}-116,1$; $\mathrm{SO}_{3}$ - 29,67; MgO - 1,935; Zn - 0,645; Cu - 0,645; Mn - 0,645; B - 0,2322; Fe - 0,258; Mo - 0,258.

Био Полимик, В - 0,2\%, Мо - 0,5\%, Со - 0,1\%, S $6 \%, \mathrm{Cu}-0,6 \%, \mathrm{Fe}-3,2 \%, \mathrm{Mn}-2,0 \%$; Микроэлементы: Co, $\mathrm{Cu}, \mathrm{Mn}, \mathrm{Fe}$ в полимерно-хелатной форме. Фитоспорин-М - 0,5\%. БМВ гуматы - 0,5\%.

Опыт закладывали в четырех повторениях, площадь делянки: общая 20 м², уборочная 10 м². Состоящие из 2-х рядков посева кукурузы длиной 7,15 м, опытные делянки нарезали на поле гибридизации кукурузы, посеянной по схеме размещения 12:4.

Осеннее применение основного удобрения под вспашку проведенную на глубину 25 - 27 см $\mathrm{N}_{60} \mathrm{P}_{60} \mathrm{~K}_{60}$ являлось общим фоном.

Система основной обработки почвы - двукратное дискование после уборки предшественника, обработка взошедших сорняков гербицидами сплошного действия (Раундап, 2,5 л/га), повторное дискование, внесение удобрения с последующей вспашкой поля под зябь.

Проводили ранневесеннее выравнивание зяби на глубину 12-14 см, предпосевное внесение почвенного гербицида, заделку гербицида предпосевной культивацией.
Площадь листовой поверхности родительских форм кукурузы и фотосинтетический потенциал посева в динамике, урожайность, структуру урожая и структуру початка определяли с использованием соответствующих стандартных методик $[1,2$,5, 6].

В восточной подзоне центральной зоны Краснодарского края почвы черноземы обыкновенные. В пахотном слое содержится от 4,0 до 6,0 \% гумуса, в глубину он постепенно убывает. Механический состав почвы тяжелосуглинистый с высокой водоудерживающей способностью, наименьшая влагоемкость в почве в слое 0,6 м составляет 28,5 \%, а в слое 1,0 м - 27,2\% [11].

Анализ почвенных образцов (по данным зональной агрохимлаборатории г. Гулькевичи) показал, что почва в пахотном слое 0-30 см среднеобеспеченна легкорастворимым азотом - 4,31-5,2 мг на 100 г почвы, повышенное содержание подвижных форм фосфора 3,0-3,4 и обменного калия 32-40 мг на 100 г почвы.

В условиях 2018 года вегетационный период для роста развития кукурузы был в конце апреля и в мае месяце на уровне многолетних значений, как по температуре воздуха, так и по выпадению осадков. В эти периоды было небольшое отклонение по относительной влажности воздуха. Июнь месяц был жарким и довольно сухим, уступающим по выпадению осадков многолетним данным более чем в три раза. Относительная влажность воздуха за все три декады была ниже нормы на 24 - 28 \%. Гидротермический коэффициент был ниже нормы за период и составил 0,5.

В 2019 году за период с апреля и до уборки урожая кукурузы (28 августа) сумма активных температур свыше $0^{\circ} \mathrm{C}$ составила $3214^{\circ} \mathrm{C}$ и была выше среднемноголетней нормы на $344^{\circ} \mathrm{C}$. При этом эффективная температура для кукурузы выше $10{ }^{\circ} \mathrm{C}$ так же превышала среднемноголетнее значение на $344^{\circ} \mathrm{C}$.

Гидротермический коэффициент составил 0,79, осадков за период вегетации выпало 248 мм, что ниже многолетней нормы на 47 мм. Относительная влажность воздуха за период была 53 \%, и уступала многолетнему значению на $12 \%$.

\section{Результаты и обсуждение}

Кукуруза является одной из важнейших культур края используемых, как на зернофуражные цели, так и на продовольственные нужды. В настоящее время проведено немного исследований для изучения обеспеченности внутреннего рынка отечественными, адаптированными к местным условиям гибридными семенами. Поэтому этот недостаток восполняется завезенными из-за рубежа необоснованно дорогостоящими семенами.

Повышение производства семян гибридов кукурузы различных групп спелости зависит не только от выведения высокопродуктивных гибридов, но и от обеспечения достаточным количеством семян, то есть создания условий на участках гибридизации для улучшения роста и развития родительских форм, позволяющих увеличить выход качественных 
гибридных семян первого поколения. Для достижения этой цели важно улучшение питательного режим на участках гибридизации в течении всего вегетационного периода. В настоящее время обеспеченность растений кукурузы минеральным питанием дополняется подкормкой органоминеральными удобрениями, среди которых особо выделяются Batr Gum, Batr Max, Batr Bor, а также, Био Полимик.

В проводимых нами экспериментах мы изучали влияние подкормки этими удобрениями вегетирующих родительских форм кукурузы в фазе 5-7 листьев. Изучение морфологических признаков в зависимости от обработки растений удобрениями показало, что у материнских форм гибрида Краснодарский 291 AMB 9 Кр 640 УМ в фазе 5-7 листьев в среднем за 2018-2019 годы высота растений составила на обработанных органоминеральными удобрениями вариантах 206,0 209,5 см, т.е. была выше контрольного варианта только в 4х вариантах при внесении Batr Gum 2-3 л/га, Batr Max 2 л/га и Био Полимик 1,0 л/га (табл. 1).

Таблица 1. Морфологические признаки материнской формы гибрида кукурузы Краснодарский 291 АМВ $९$ Кр 640 УМ в фазе молочно-восковой спелости зерна (2018-2019 гг)

\begin{tabular}{|l|c|c|c|}
\hline \multicolumn{1}{|c|}{ Вариант опыта } & $\begin{array}{c}\text { Высота } \\
\text { растений, см }\end{array}$ & $\begin{array}{c}\text { Площадь листовой } \\
\text { поверхности, тыс. м²/га }\end{array}$ & $\begin{array}{c}\text { Фотосинтетический } \\
\text { потенциал посева, тыс. м²/га } \\
\text { х дней }\end{array}$ \\
\hline 1. Контроль - без обработки & 201,5 & 32,5 & 1788 \\
\hline 2. Batr Gum, 2 л/га & 209,5 & 34,2 & 1878 \\
\hline 3. Batr Gum, 3 л/га & 208,0 & 34,6 & 1941 \\
\hline 4. Batr Max, 2 л/га & 207,5 & 34,9 & 1920 \\
\hline 5. Batr Bor, 0,5 л/га & 206,0 & 34,9 & 1920 \\
\hline 6. Био Полимик, 1 л/га & 208,5 & 34,2 & 1878 \\
\hline НСР & 7,7 & 1,5 & 100,3 \\
\hline
\end{tabular}

Подкормки органоминеральными удобрениями повлияли на площадь листовой поверхности материнской формы. Так, величина признака «площадь листьев» на необработанном варианте была 32,5 тыс. м²/га, а на обработанных она увеличивалась на 1,7 - 2,4 тыс. м²/га. Максимальное увеличение площади листьев отмечено на вариантах внесения Batr Max 2 л/га, Batr Bor, 0,5 л/га, где она достигала одинаковой величины 34,9 тыс. м²/га.

Фотосинтетический потенциал посева существен- но превышал величину контрольного варианта в трех случаях, когда обработку вегетирующих растений проводили Batr Gum 3 л/га, Batr Max 2 л/га, Batr Bor, 0,5 л/га, где были получены равные результаты 1941, 1920 и 1920 тыс. м²/га х дней.

Подкормки растений кукурузы органоминеральными удобрениями улучшали рост, развитие, способствовали лучшему и более дружному цветению початка у материнских растений и пыльцеобразованию на метелках отцовских форм §ै Кр 244 МВ (табл. 2).

Таблица 2. Масса метелки и пыльцы у отцовских растений гибрида кукурузы Краснодарский 291 AMB, ¿̊ Кр 244 МВ в зависимости от обработки органоминеральными удобрениями, (2018 - 2019 гг.)

\begin{tabular}{|c|c|c|c|c|}
\hline \multirow{3}{*}{ Вариант опыта } & \multicolumn{4}{|c|}{ Масса с одного растения, г } \\
\hline & \multicolumn{2}{|c|}{ метелки } & \multicolumn{2}{|c|}{ пыльцы } \\
\hline & сырой & сухой & сырой & сухой \\
\hline 1. Контроль - без обработки & 25,5 & 9,15 & 1,14 & 0,72 \\
\hline 2. Batr Bor, 0,5 л/га & 32,8 & 10,06 & 1,56 & 0,92 \\
\hline 3. Био Полимик, 1 л/га & 27,8 & 11,90 & 1,40 & 0,88 \\
\hline
\end{tabular}

Увеличение сухой массы пыльцы с одного растения составило 0,20 г при подкормке Batr Bor, 0,5 л/га и 0,16 г при подкормке Био Полимик, 1 л/га.

Урожайность зерна материнских форм на вариантах подкормки вегетирующих растений органоминеральными удобрениями повышалась по сравнению с необработанным вариантом в 2018 году на варианте обработки растений кукурузы Batr Gum 2 и 3 л/га и Batr Max 2 л/га (табл. 3).

В опыте 2019 года необработанный вариант уступал всем испытываемым на 0,50-0,88 т/га при $\mathrm{HCP}_{05}$ 0,29 т/га.
Средняя урожайность зерна за 2018 - 2019 гг. материнской формы ф Кр 640 УМ с обработкой растений в фазе 5 - 7 листьев составила 5,68 - 5,94 т/га, при урожайности на контроле 5,24 т/га.

Наибольшую урожайность зерна обеспечили варианты с внесением Batr Gum 2 и 3 л/га, Batr Max, 2 л/га и Био Полимик, 1 л/га. Получение высоких урожаев зерна подтверждено данными структуры урожая зерна - массой початка, выхода зерна с початка и массой 1000 зерен, где данные увеличились по сравнению с контрольным вариантом (табл. 4). 
Таблица 3. Урожайность зерна материнской формы гибрида кукурузы Краснодарский 291 АМВ Кр 640 УМ в зависимости от обработки в фазе 5-7 листьев органоминеральными удобрениями, т/ га, (2018-2019 гг.)

\begin{tabular}{|c|c|c|c|}
\hline \multirow{2}{*}{ Вариант опыта } & \multicolumn{2}{|c|}{ Год исследований } & \multirow{2}{*}{$\begin{array}{l}\text { Среднее за } \\
2018-2019 \text { гг. }\end{array}$} \\
\hline & 2018 & 2019 & \\
\hline 1. Контроль - без обработки & 4,86 & 5,62 & 5,24 \\
\hline 2. Batr Gum, 2 л/га & 5,39 & 6,44 & 5,92 \\
\hline 3. Batr Gum, 3 л/га & 5,37 & 6,50 & 5,94 \\
\hline 4. Batr Max, 2 л/га & 5,33 & 6,43 & 5,88 \\
\hline 5. Batr Bor, 0,5 л/га & 5,24 & 6,12 & 5,68 \\
\hline 6. Био Полимик, 1 л/га & 5,21 & 6,42 & 5,82 \\
\hline $\mathrm{HCP}_{05}$ & 0,44 & 0,29 & - \\
\hline
\end{tabular}

Таблица 4. Структура урожая материнской формы гибрида кукурузы

Краснодарский 291 АМВ $\subsetneq$ Кр 640 УМ в зависимости от обработки вегетирующих растений органоминеральными удобрениями, (2018 - 2019 гг.)

\begin{tabular}{|l|c|c|c|}
\hline \multirow{2}{*}{ Вариант опыта } & \multicolumn{2}{c|}{ Масса, г } \\
\cline { 2 - 4 } & одного початка & зерна с одного початка & $\mathbf{1 0 0 0 ~ з е р е н ~}$ \\
\hline 1. Контроль - без обработки & 110,2 & 98,9 & 32 \\
\hline 2. Batr Gum, 2 л/га & 125,4 & 111,1 & 313 \\
\hline 3. Batr Gum, 3 л/га & 123,3 & 108,5 & 316 \\
\hline 4. Batr Max, 2 л/га & 122,8 & 116,1 & 314 \\
\hline 5. Batr Bor, 0,5 л/га & 113,6 & 103,9 & 311 \\
\hline 6. Био Полимик, 1 л/га & 123,4 & 110,6 & \\
\hline
\end{tabular}

Масса одного початка на контрольном варианте составила 110,2 г и с обработкой растений увеличивалась на 3,4 - 15,2 г. Выход зерна с початка на контроле составил 98,9 г, а на обработанных органоминеральными удобрениями вариантах увеличивался на 5,0 до 17,2 г. Увеличение массы
1000 зерен по сравнению с контролем достигало 22 - 34 г. Увеличение зерновой продуктивности от подкормки органоминеральными удобрениями имело место только при подкормке Био Полимик, 1 л/га, и составило по сравнению с контролем 0,59 т/га (табл.5).

Таблица 5. Урожайность зерна и структура урожая отцовских форм гибрида кукурузы Краснодарский 291 АМВ $\precsim$ Кр 244 МВ в зависимости от обработки вегетирующих растений органоминеральными удобрениями в фазе 5-7 листьев, (2018-2019 гг.)

\begin{tabular}{|l|c|c|c|c|}
\hline \multirow{2}{*}{ Вариант опыта } & \multirow{2}{*}{$\begin{array}{c}\text { Урожайность } \\
\text { зерна, т/га }\end{array}$} & початка & зерна с початка & 1000 зерен \\
\cline { 3 - 5 } & 5,35 & 106,4 & 85,6 & 250 \\
\hline 1. Контроль - без обработки & 5,75 & 114,2 & 95,2 & 260 \\
\hline 2. Batr Bor, 0,5 л/га & 5,94 & 111,0 & 90,2 & 260 \\
\hline 3. Био Полимик, 1 л/га & 0,43 & - & - & - \\
\hline $\mathrm{HCP}_{05}$ & &
\end{tabular}

\section{Выводы}

Применение органоминеральных удобрений при обработке вегетирующих растений родительских форм кукурузы повысило показатели их морфо- логических признаков, увеличило ФП на 5-9 \%, пыльцеобразование отцовской формы на 22-28 \% и способствовало повышению урожайности зерна материнских растений на 0,44 - 0,70 т/га.

\section{ЛИТЕРАТУРА}

1. Доспехов, Б.А. Планирование полевого опыта и статистическая обработка его данных / Б.А. Доспехов. - М.: «Колос», 1972. - 205 с.

2. Кукуруза. Современная технология возделывания / В.С. Сотченко. 2-е издание, дополнительное, М.: ООО МПО «РосАгроХим», 2014. - 128 с.

3. Малько, А.М. Оценка состояния и качества семян кукурузы и роль сертификации в его повышении / А.М. Малько // Кукуруза и сорго. - 2005. - №1. - С. 14-15.

4. Методика государственного сортоиспытания сельскохозяйственных культур. - М., 1976. - 304 с.

5. Методические указания по производству гибридных и сортовых семян кукурузы / Б.П. Соколов, М.И. Хаджинов, Г.С. Галеев [и др.]. - М.: Колос, 1975. - 168 с.

6. Методические указания по производству гибридных семян кукурузы. - Пятигорск, 2007. - 20 с. 
7. Найденов, А.С. Доли влияния и эффективность взаимодействия способов обработки почв и доз минеральных удобрений на урожайность кукурузы на обыкновенном черноземе Западного Предкавказья / А.С. Найденов, С.Е. Егоян // Труды КубГАУ. - 2007. - Вып. 2. - С. 11-13.

8. Никитин, С.Н. Фотосинтетическая деятельность растений в посевах и динамика ростовых процессов при применении биологических препаратов / С.Н. Никитин // Успехи современного естествознания. - 2017. - № 1. - С. $33-38$.

9. Семина, С.А. Урожайность зерна кукурузы в зависимости от листовой подкормки комплексными удобрениями / С.А. Семина, И.В. Гаврюшина // Нива Поволжья. - 2019. - № 4 (53). - С. 29-35.

10. Сотченко, В.С. Состояние и перспективы семеноводства кукурузы / В.С. Сотченко, Ю.В. Сотченко // Кукуруза и сорго. - 2014. - № 7. - С. 3-7.

11. Терпелец, В.И. Почвенно-агроэкологические основы рекультивации земель в условиях Западного Предкавказья: автореф. дис. ... д-ра с.-х. наук: // 06.01.03 / В.И. Терпелец. - Краснодар, 2001. - 45 с.

12. Фокин, С.А. Влияние способов применения микроудобрений на продуктивность кукурузы / С.А. Фокин, В.А. Радикорская, И.В. Куркова, Н.П. Калашников // Дальневосточный аграрный вестник. - 2018. - № 1 (45). - С. 53-59.

13. Циков, В.С., Матюха, Л.А. Интенсивная технология возделывания кукурузы / В.С. Циков, Л.А. Матюха / - М.: Агропромиздат. 1989. - 247 С.

\section{REFERENCES}

1. Dospekhov, B.A. Field experiment planning and statistical processing of its data / B.A. Dospekhov. - M.: "Kolos", 1972. - 205 p.

2. Corn. Modern technology of cultivation / V.S. Sotchenko. 2nd edition, additional, M.: LLC MPO "RosAgroKhim”, 2014 - 128 p.

3. Malko, A.M. Assessment of the state and quality of corn seeds and the role of certification in its improvement / A.M. Malko // Corn and sorghum. - 2005. - № 1. - P. 14-15.

4. Methodology for state variety testing of agricultural crops. - M., 1976. - 304 p.

5. Guidelines for the production of hybrid and varietal seeds of corn / B.P. Sokolov, M.I. Khadzhinov, G.S. Galeev [and others]. - M.: Kolos, 1975. - 168 p.

6. Guidelines for the production of hybrid corn seeds. - Pyatigorsk, 2007. - $20 \mathrm{p.}$

7. Naydenov, A.S. Shares of influence and effectiveness of interaction of methods of soil cultivation and doses of mineral fertilizers on corn yield on ordinary chernozem of Western Ciscaucasia / A.S. Naydenov, S.E. Egoyan // Proceedings of the KubSAU. - 2007. - Issue. 2. - P. 11-13.

8. Nikitin, S.N. Photosynthetic activity of plants in crops and dynamics of growth processes when using biological preparations / S.N. Nikitin // Successes of modern natural science. - 2017. - № 1. - P. 33-38.

9. Semina, S.A. Corn grain yield depending on foliar feeding with complex fertilizers / S.A. Semina, I.V. Gavryushina // Niva of the Volga region. - 2019. - № 4 (53). - P. 29-35.

10. Sotchenko, V.S. State and prospects of corn seed production / V.S. Sotchenko, Yu.V. Sotchenko // Corn and sorghum. - 2014. - № 7. - P. 3-7.

11. Terpelets, V.I. Soil-agroecological foundations of land reclamation in the conditions of the Western Ciscaucasia: author. dis.... Dr. s.-kh. sciences: // 06.01.03 / IN AND. Patient. - Krasnodar, 2001. - 45 p.

12. Fokin, S.A. Influence of methods of application of microfertilizers on corn productivity / S.A. Fokin, V.A. Radikorskaya, I.V. Kurkova, N.P. Kalashnikov // Far Eastern Agrarian Bulletin. - 2018. - № 1 (45). - P. 53-59.

13. Tsikov, V.S., Matyukha, L.A. Intensive corn cultivation technology/V.S. Tsikov, L.A. Matyukha / - M.: Agropromizdat. 1989. - 247 p.

\section{Никитенко Александр Борисович \\ Аспирант отдела селекции и \\ семеноводства кукурузы}

\section{Малаканова Валентина Пантелеевна}

Ведущий научный сотрудник отдела селекции и семеноводства кукурузы

\section{Марченко Марина Валерьевна}

Старший научный сотрудник отдела селекции семеноводства кукурузы

E-mail: marchenko_ncz@mail.ru

\section{Кирячек Сергей Андреевич}

Младший научный сотрудник отдела

селекции и семеноводства кукурузы, аспирант

E-mail: kiryachek_95@mail.ru

Bce: ФГБНУ «НЦЗ им. П.П. Лукьяненко» 350012, Россия, г. Краснодар, Центральная Усадьба КНИИСХ

\section{Nikitenko Alexander Borisovich}

Postgraduate student of the breeding department and corn seed production

\section{Malakanova Valentina Panteleevna}

Leading Researcher of the Department breeding and seed production of corn

\section{Marchenko Marina Valerievna}

Senior Researcher of the Department

seed breeding corn

E-mail: marchenko_ncz@mail.ru

\section{Kiryachek Sergey Andreevich}

Junior Researcher of the Department breeding and seed production of corn, graduate student

E-mail: kiryachek_95@mail.ru

All: Federal State Budget Scientific Institution «National Center of Grain named after P.P. Lukyanenko »

Central Manor of KNIISH, Krasnodar, 350012, Russia 


\section{АГРОНОМИЧЕСКАЯ ЭФФЕКТИВНОСТЬ ПРЕПАРАТА ЗЕРОМИКС 3000 РРМ НА СЕМЕНОВОДЧЕСКИХ ПОСЕВАХ ДЫНИ СОРТА СЛАВИЯ}

В результатах исследования показана эффективность применения препарата Зеромикс 3000 ppm при совместном применении с органо-силиконовым суперсмачивателем Мадже Стик по защите растений дыни сорта Славия на семеноводческих посевах от широкого спектра патогенов. Несмотря на сильные механические повреждения растений градом при двукратном опрыскивании степень поражения пероноспорозом не превышала $15 \%$ и бактериозом не более $14 \%$. Трехкратная обработка Зеромикс 3000 pрm полностью остановила распространение болезней и до самой уборки, в течение трех недель, прослеживалось защитное действие препарата. Повреждение растений оставалось на уровне 5-6 \%. Фотосинтетическая продуктивность сохраненного ассимиляционного аппарата обеспечила увеличение урожайности плодов дыни на 8,4-28,3%, в сравнении с вариантом без обработки. Максимальное количество семян (более 15 г) вызревало в плодах дыни при двукратном опрыскивании растений. При трехкратном применении препарата отмечено снижение семенной продуктивности в среднем более чем на 4 г семян. Несмотря на это, благодаря увеличению урожайности плодов, было получено семян на 54,2 кг больше чем в контроле. Были получены семена с высокими показателями посевных качеств. Однако было отмечено, что с увеличением кратности обработок препаратом у семян заметно снижались показатели энергии прорастания (на 4-22 \%) и всхожести (на 4-8 \%) семян. Возможно, этому способствовало токсическое воздействие серебра. Для повышения биологической эффективности и исключения токсического воздействия на растения и семена препарата Зеромикс 3000 ррт необходимо планировать кратность обработок в зависимости от степени повреждения растений.

Ключевые слова: дыня, семеноводство, защита от патогенов, препарат Зеромикс 3000 ррт, урожайность, семена.

\section{AGRONOMIC EFFICIENCY OF THE PREPARATION ZEROMIX 3000 PPM ON SEED CROPS OF MELON VARIETY SLAVIA}

The results of the study show the effectiveness of the use of Zeromix 3000 ppm when used together with the organo-silicone super-wetting agent Madje Stick to protect plants of the Slavia melon variety on seed crops from a wide range of pathogens. Despite the strong mechanical damage to plants by hail after two repeated spraying, the degree of damage by peronosporosis did not exceed $15 \%$ and bacteriosis did not exceed 14\%. Three times treatment of Zeromix with 3000 ppm completely stopped the spread of diseases and until the harvest itself, for three weeks, the protective effect of the drug was traced. Plant damage remained at the level of 5-6\%. The photosynthetic productivity of the preserved assimilation apparatus provided an increase in the yield of melon fruits by $8.4-28.3 \%$, in comparison with the variant without treatment. The maximum number of seeds (more than $15 \mathrm{~g}$ ) ripened for the fruits of the melon after spraying the plants twice. With three times the use of the drug, a decrease in seed productivity was noted on average by more than $4 \mathrm{~g}$ of seeds. Despite this, due to the increase in fruit yield, seeds were obtained by $54.2 \mathrm{~kg}$ more than in the control. Seeds were obtained with high sowing rates. However, it was noted that with an increase in the frequency of treatments with the preparation, the seed energy (by 4-22\%) and germination (by 4-8\%) indicators of seeds significantly decreased. Perhaps this was due to the toxic effects of silver. To increase the biological efficiency and eliminate the toxic effect on plants and seeds of Zeromix 3000 ppm, it is necessary to plan the frequency of treatments depending on the degree of plant damage.

Key words: melon, seed production, protection against pathogens, Zeromix 3000 ppm, yield, seeds.

\section{Введение}

Агротехника при выращивании семян сортов дыни существенно не отличается от выращивания товарной продукции. Требуется особо тщательный уход за семеноводческими посевами, чтобы существенно повысить коэффициент размножения семян. Особого подхода требует применение пестицидов. С точки зрения отбора и поддержания устойчивых форм нежелательно применение пестицидов, но в некоторых случаях невозможно полностью отказаться от их применения, так как это может привести к гибели посевов или потере урожая семян [1, 2]. Сегодня на рынке представлено большое разнообразие принципиально новых препаратов, обеспечивающих комплексную защиту растений от грибковых и бактериальных болезней, содержащих в своем составе различные наборы микроэлементов. Кроме защитных функций 
они обладают ростостимулирующим действием и способствуют активации собственной системы защиты организма растений от патогенов [3, 4, 5].

Группа компаний «АгроХимПром» предлагает на вегетирующих растениях использовать препарат Зеромикс 3000 ppm. Из рекомендаций производителя видно, что это препарат на основе коллоидного серебра, является бактерицидом и фунгицидом трансламинарного действия, обеспечивающий укрепление фитоиммунитета и стимуляцию роста растения. В тоже время избыточное количество серебра может оказывать токсическое воздействие на растения $[6,12,13]$. Несмотря на большой объём накопленных данных, остается открытыми вопросы по оптимальной схеме применения препарата на конкретных культурах.

\section{Цель исследований}

Установить агрономическую эффективность препарата Зеромикс 3000 ррт при совместном применении с органо-силиконовым суперсмачивателем Мадже Стик, на семеноводческих посевах дыни сорта Славия.

\section{Материалы и методы}

Объектами исследований являлись семеноводческие посевы дыни сорта Славия и препарат Зеромикс 3000 ррт с совместным применением органо-силиконового суперсмачивателя Мадже Стик.

Место проведения опыта - селекционно-семеноводческий участок отдела овощеводства, ФГБНУ «ФНЦ риса», г. Краснодар. Предшественник - озимая пшеница. Посев осуществляли вручную. Схема посева: 2,0 x 0,7 м. Площадь учетной делянки - 60 м², размещение - систематическое, повторность - четырехкратная. Эффективность вариантов оценивали на фоне минерального питания $-\mathrm{N}_{50} \mathrm{P}_{50} \mathrm{~K}_{50}$. Удобрение (нитроаммофоска) вносили перед посевом. При закладке опытов и проведении исследований использовали методику полевого опыта в овощеводстве С.С. Литвинова [8]. Биологическую эффективность фунгицидов определяли по формуле Аббота [9]. Агротехнику выращивания дыни на опытном участке выполняли в соответствии с рекомендациями, разработанными в отделе овощекартофеле- водства ФГБНУ «ВНИИ риса» [10]. Статистическая обработка полученных данных проведена согласно методическим рекомендациям А.Х. Шеуджена [11].

Схема опыта включала следующие варианты:

1. Контроль (без обработки)

2. Зеромикс 3000 ррm + МаджеСтик, 2-х кратное опрыскивание

3. Зеромикс 3000 ppm + МаджеСтик, 3-х кратное опрыскивание

Норма расхода препарата Зеромикс 0,3 л/га + МаджеСтик 0,15 л/га.

Расход рабочей жидкости: 250 л/га.

Первая обработка вегетирующих растений в фазу «шатра» при наличии 4-6 настоящих листьев, вначале плетеобразования (17.06.2020).

Вторая обработка вегетирующих растений в фазу цветения и начала роста плодов (02.07.2020).

Третья обработка в фазу роста плодов, размер завязей 4-7 см (12.07.2020).

\section{Результаты и обсуждение}

Погодные условия в июне спровоцировали развитие бактериоза на растениях дыни. Первая обработка Зеромиксом 3000 ррm, в фазу «шатра», практически остановила дальнейшее распространение патогена. В начале цветения на растениях появились очаги повреждения пероноспорозом, которые спровоцировали осадки (туман). Грибное поражение было отмечено на растениях в контрольном и обработанном вариантах. Второе опрыскивание способствовало локализации очагов поражения пероноспорозом и бактериоз ом. Степень поражения листьев в контрольном варианте составляла 35 \%, в то время как на обработанных растениях поражение листьев не превышало 2 \%. Для улучшения фитосанитарного состояния посевов дыни через 10 дней повторили опрыскивание Зеромикс 3000 рpm. Было отмечено, что в варианте, где растения обрабатывали три раза, развитие бактериоза и пероноспороза не происходило. В варианте с двукратной обработкой распространение болезней не превышало 8 \%. В контрольном варианте повреждение вегетативной массы дыни было на уровне 42 \% (табл.1).

Таблица 1. Фитосанитарная оценка и динамика распространения заболеваний на посевах дыни

\begin{tabular}{|c|c|c|c|c|}
\hline \multirow{3}{*}{ Вариант } & Степень разви & ппороза, \% & Степень p & актериоза, \% \\
\hline & \multicolumn{4}{|c|}{ Дата проведения осмотра } \\
\hline & 22.06.20 & 07.07 .20 & 22.06.20 & 07.07.20 \\
\hline Контроль & 35 & 42 & 22 & 29 \\
\hline $\begin{array}{l}\text { Зеромикс3000 ppm, } \\
\text { 2-х кратная обработка }\end{array}$ & $\begin{array}{l}12 \\
10\end{array}$ & $\begin{array}{c}15 \\
8\end{array}$ & $\begin{array}{l}12 \\
6\end{array}$ & $\begin{array}{l}14 \\
7\end{array}$ \\
\hline $\begin{array}{l}\text { Зеромикс } 3000 \text { ррm, } \\
\text { 3-х кратная обработка }\end{array}$ & 6 & 6 & 5 & 5 \\
\hline
\end{tabular}

Через 8 дней (20.07.2020) после последней обработки растения дыни значительно пострадали от града. Более 50 \% вегетативной массы и формирующихся плодов дыни были повреждены. Следует отметить, что применение препарата Зеромикс 3000 рpm способствовало значительному улучшению фитосанитарного состояния поврежденных посевов дыни и позволило получить плоды более крупного размера (табл. 2). При трехразовом применении изучаемого препарата масса плодов в первом сборе в среднем на 30,6 \% превышала массу плодов в варианте без обработки, а плоды второго сбора более чем в 2 раза были крупнее. 
Таблица 2. Влияние обработки растений препаратом Зеромикс 3000 ррm на биометрические параметры плодов дыни

\begin{tabular}{|c|c|c|c|c|c|c|}
\hline \multirow{3}{*}{ Вариант } & \multirow{2}{*}{\multicolumn{2}{|c|}{ Macca, $\mathbf{~ к r}$}} & \multicolumn{4}{|c|}{ Диаметр, см } \\
\hline & & & \multicolumn{2}{|c|}{ Продольный, h } & \multicolumn{2}{|c|}{ Поперечный, d } \\
\hline & «min-max» & средняя & «min-max» & средний & «min-max» & средний \\
\hline \multicolumn{7}{|c|}{ 1-й сбор плодов } \\
\hline Контроль & $0,87-1,24$ & 1,13 & $10-13$ & 12 & $7-11$ & 8,0 \\
\hline $\begin{array}{l}\text { Зеромикс3000 ррm, } \\
\text { 2-кратная обработка }\end{array}$ & $0,98-1,46$ & 1,21 & $11-16$ & 14 & $10-13$ & 10,1 \\
\hline $\begin{array}{l}\text { Зеромикс } 3000 \text { ррт, } \\
\text { 3-х кратная обработка }\end{array}$ & $0,96-1,62$ & 1,38 & $13-21$ & 18 & $11-16$ & 13,0 \\
\hline \multicolumn{7}{|c|}{ Для массы плодов $\mathrm{F}_{\text {факт. }} 10,29>\mathrm{F}_{\text {теор. }} 5,14$} \\
\hline \multicolumn{7}{|c|}{2 2-й сбор плодов } \\
\hline Контроль & $1,20-1,33$ & 1,29 & $12-16$ & 14 & $10-12$ & 11,0 \\
\hline $\begin{array}{l}\text { Зеромикс3000 ppm, } \\
\text { 2-кратная обработка }\end{array}$ & $1,05-2,04$ & 1,69 & $13-19$ & 17 & $11-13$ & 11,7 \\
\hline $\begin{array}{l}\text { Зеромикс } 3000 \text { ррт, } \\
\text { 3-х кратная обработка }\end{array}$ & $1,65-2,98$ & 2,76 & $15-27$ & 23 & $11-18$ & 16,0 \\
\hline \multicolumn{7}{|c|}{ Для массы плодов $\mathrm{F}_{\text {факт. }} 11,25>\mathrm{F}_{\text {теор. }} 5,14 \quad \mathrm{HCP}_{05}=0,27 \mathrm{kг}$} \\
\hline
\end{tabular}

Обработка растений дыни препаратом Зеромикс 3000 ppm способствовала достоверному увеличению общей урожайности; при двукратном опрыскивании на 8,4 \%, при трехкратном - на 28,3 \%. Лучшим оказался вариант трехкратного опрыскивания. В результате его применения достоверное превышение над контролем при первом сборе плодов дыни составило 0,75 т/га, при втором сборе - 0,94 т/га (табл. 3). С растений, обработанных препаратом Зеромикс 3000 ррт два раза, при каждом сборе собирали урожай плодов на 0,4 - 0,5 т/ га больше, чем с варианта без обработки.
Применение препарата Зеромикс 3000 ppm даже после значительных повреждений градом фитомассы растений, сдерживало развитие бактериоза и пероноспороза до сбора урожая. Cохранность ассимиляционной поверхности способствовала большему накоплению сухих растворимых веществ в мякоти плодов (СРВ). Максимальное содержание СРВ было в варианте трехкратного применения фунгицида - 10,7 \%, что на 12,6 \% больше, чем в варианте без обработки. При двукратной обработке разница в среднем составляла 5,3 \%.

Таблица 3. Влияние обработки растений препаратом Зеромикс 3000 ррт на урожайность и накопление сухих растворимых веществ (СРВ) в мякоти плодов дыни

\begin{tabular}{|c|c|c|c|c|c|}
\hline \multirow{3}{*}{ Вариант } & \multicolumn{2}{|c|}{ Урожайность } & \multicolumn{3}{|c|}{ CPB } \\
\hline & \multirow{2}{*}{ т/га } & \multirow{2}{*}{ 土 к контролю, \% } & \multicolumn{2}{|c|}{$\%$} & \multirow{2}{*}{ 土 К контролю, \% } \\
\hline & & & «min-max» & среднее & \\
\hline \multicolumn{6}{|c|}{ 1-й сбор плодов } \\
\hline Контроль & 3,39 & - & $6,9-12,2$ & 9,6 & - \\
\hline $\begin{array}{l}\text { Зеромикс3000 ppm, } \\
\text { 2-кратная обработка }\end{array}$ & 3,79 & $+11,8$ & $7,1-12,8$ & 10,1 & $+5,2$ \\
\hline $\begin{array}{l}\text { Зеромикс } 3000 \text { ррт, } \\
\text { 3-х кратная обработка }\end{array}$ & 4,14 & $+22,1$ & $7,0-13,2$ & 10,5 & $+9,4$ \\
\hline \multicolumn{6}{|c|}{ 2-й сбор плодов } \\
\hline Контроль & 2,58 & - & $6,5-12,0$ & 9,3 & - \\
\hline $\begin{array}{l}\text { Зеромикс3000 ррm, } \\
\text { 2-кратная обработка }\end{array}$ & 3,08 & $+19,4$ & $5,5-12,5$ & 9,9 & $+6,5$ \\
\hline $\begin{array}{l}\text { Зеромикс } 3000 \text { ррm, } \\
\text { 3-х кратная обработка }\end{array}$ & 3,52 & $+36,4$ & $6,8-12,9$ & 11,0 & $+11,8$ \\
\hline \multicolumn{6}{|c|}{ Общая } \\
\hline Контроль & 5,97 & - & $6,5-12,2$ & 9,5 & - \\
\hline $\begin{array}{l}\text { Зеромикс3000 ррm, } \\
\text { 2-кратная обработка }\end{array}$ & 6,87 & $+8,4$ & $5,5-12,8$ & 10,0 & $+5,3$ \\
\hline $\begin{array}{l}\text { Зеромикс } 3000 \text { ррm, } \\
\text { 3-х кратная обработка }\end{array}$ & 7,66 & $+28,3$ & $6,8-13,2$ & 10,7 & $+12,6$ \\
\hline \multicolumn{6}{|c|}{ 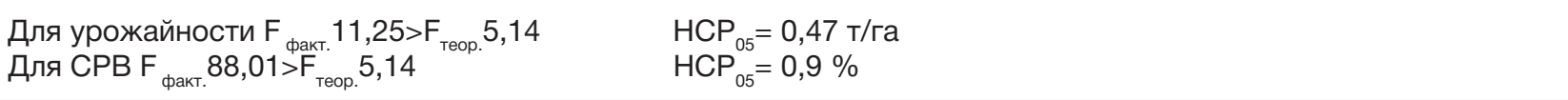 } \\
\hline
\end{tabular}


Анализ полученных результатов показал, как применение препарата Зеромикс 3000 ррm повлияло на семенную продуктивность дыни. Максимальное количество семян от 443 до 477 штук было выделено из плодов, убранных с делянок, дважды обработанных препаратом. В среднем с каждого плода удалось получить по 15,4 г семян. При трехкратном применении Зеромикса 3000 ррт отмечено значительное снижение семенной продуктивности дыни. В плодах сформировалось от 260 до 372 штук се- мян. Выход семян составил в среднем на 2,4 г меньше, чем в плодах контрольного варианта (табл. 4).

При планируемом расчете энергозатрат на выделение семян из урожая плодов, необходимо знать какая доля семян составляет от общей массы плодов. В опыте доля семян составляла от 0,69 \% до 1,05 \% и зависела от размера плодов. Обработка препаратом Зеромикс 3000 ррm способствовала увеличению массы плодов дыни, но чем крупнее плоды, тем меньше доля семян.

Таблица 4. Влияние обработок препаратом Зеромикс 3000 ppm на семенную продуктивность дыни сорта Славия

\begin{tabular}{|c|c|c|c|c|c|c|}
\hline \multirow[t]{2}{*}{ Вариант } & \multicolumn{2}{|c|}{ Масса плода, кг } & \multicolumn{2}{|c|}{$\begin{array}{c}\text { Масса семян в одном } \\
\text { плоде, г }\end{array}$} & \multicolumn{2}{|c|}{$\begin{array}{c}\text { Доля семян от массы } \\
\text { плода, \% }\end{array}$} \\
\hline & «min»- «max» & средняя & «min»-«max» & средняя & «min»-«max» & средняя \\
\hline контроль & $1,26-1,33$ & 1,29 & $11,0-16,1$ & 13,6 & $0,87-1,21$ & 1,05 \\
\hline $\begin{array}{l}\text { 2-кратная } \\
\text { обработка }\end{array}$ & $1,25-2,76$ & 2,00 & $12,4-18,5$ & 15,4 & $0,99-0,67$ & 0,77 \\
\hline $\begin{array}{l}\text { 3-х разовая } \\
\text { обработка }\end{array}$ & $1,05-2,46$ & 2,28 & $7,9-14,4$ & 11,2 & $0,59-0,75$ & 0,69 \\
\hline \multicolumn{7}{|c|}{$\begin{array}{ll}\text { Для массы плода } \mathrm{F}_{\text {факт. }} 5,73>\mathrm{F}_{\text {теор. }} 4,26 & \mathrm{HCP}_{05}=0,21 \mathrm{kr} \\
\text { Для массы семян в плоду } \mathrm{F}_{\text {факт. } 11,47>\mathrm{F}_{\text {теор. }} 4,26} & \mathrm{HCP}_{05}=0,15 \text { г } \\
\text { Для доли семян от массы плода } \mathrm{F}_{\text {факт. }}{ }^{4,64>\mathrm{F}_{\text {теор. }} 3,49} & \mathrm{HCP}_{05}=0,7 \%\end{array}$} \\
\hline
\end{tabular}

Благодаря фунгицидному и бактерицидному воздействию препарата на патогены, на обработанных растениях сохранность и фотосинтетическая активность ассимиляционной поверхности была выше, что обеспечило не только увеличение урожайности плодов на 8,4-28,3 \% но и получить урожай семян на 27,2 - 54,2 кг больше, чем в контрольном варианте (табл. 5). Максимальную прибавку урожая семян обеспечила трех кратная обработка растений.
Обработка Зеромикс 3000 ррт остановила развитие пероноспороза и бактериоза на дыни, чем меньше было повреждение ассимиляционной поверхности растений, тем больше масса 1000 семян. Однако вероятно токсическое воздействие серебра повлияло на посевные качества семян. С увеличением кратности обработок препаратом у семян заметно снижались показатели энергии и всхожести семян (табл. 6).

Таблица 5. Влияние обработки препаратом Зеромикс 3000 ppm на урожайность плодов и семян дыни сорта Славия

\begin{tabular}{|c|c|c|c|c|}
\hline \multirow{3}{*}{ Вариант } & \multicolumn{4}{|c|}{ Урожайность } \\
\hline & \multicolumn{2}{|c|}{ плодов } & \multicolumn{2}{|c|}{ семян } \\
\hline & т/га & 土 К контролю, \% & кг/га & 土 К контролю,\% \\
\hline Контроль & 5,97 & - & 56,8 & - \\
\hline $\begin{array}{l}\text { Зеромикс3000 ррт, } \\
\text { 2-кратная обработка }\end{array}$ & 6,47 & $+8,4$ & 84,0 & $+47,9$ \\
\hline $\begin{array}{l}\text { Зеромикс } 3000 \text { ppm, } \\
\text { 3-х кратная обработка }\end{array}$ & 7,66 & $+28,3$ & 111,0 & $+95,4$ \\
\hline \multicolumn{5}{|c|}{$\begin{array}{l}\text { Для урожайности плодов } \mathrm{F}_{\text {факт. }} 11,25>\mathrm{F}_{\text {теор. }} 5,14 \\
\text { Для урожайности семян } \mathrm{F}_{\text {факт. }} .35,41>\mathrm{F}_{\text {теор. }} 5,14\end{array}$} \\
\hline
\end{tabular}

Таблица 6. Влияние препарата Зеромикс 3000 ppm на массу и посевные качества семян дыни сорта Славия

\begin{tabular}{|c|c|c|c|c|}
\hline \multirow{2}{*}{ Вариант } & \multicolumn{2}{|c|}{ Масса 1000 семян, г } & \multirow{2}{*}{$\begin{array}{c}\text { Энергия, \% } \\
\text { (5 дней) }\end{array}$} & \multirow{2}{*}{$\begin{array}{c}\text { Всхожесть, \% } \\
\text { (12 дней) }\end{array}$} \\
\hline & «min»»-«max» & средняя & & \\
\hline Контроль & $31,9-32,6$ & 32,3 & 43 & 100 \\
\hline $\begin{array}{l}\text { Зеромикс3000 ррт, } \\
\text { 2-кратная обработка }\end{array}$ & $28,0-36,2$ & 33,5 & 39 & 96 \\
\hline $\begin{array}{l}\text { Зеромикс } 3000 \text { ррm, } \\
\text { 3-х кратная обработка }\end{array}$ & $30,4-35,5$ & 34,3 & 21 & 92 \\
\hline \multicolumn{5}{|c|}{ Для массы 1000 семян $\mathrm{F}_{\text {факт. }} 5,73>\mathrm{F}_{\text {теор. }} 4,26 \quad \mathrm{HCP}_{05}=2,9$ г } \\
\hline
\end{tabular}




\section{Выводы}

Применение препарата Зеромикс 3000 ppm в виде некорневой обработки посевов дыни в период вегетации способствовало лучшему сохранению ассимиляционной поверхности листьев и снижению степени повреждения растений бактериозом и пероноспорозом.

Максимальный защитный эффект наблюдался при трехкратной обработке растений, который сохранялся в течение месяца после последнего опрыскивания растений и до сбора урожая. Несмотря на сильные механические повреждения, фитопатогенное состояние посевов оставалось благоприятным и позволило получить урожай плодов дыни на 1,69 т/га и семян на 54,2 кг больше, чем с необработанных участков.

Подавление препаратом Зеромикс3000 ppm распространения бактериоза и пероноспороза на ассимиляционной поверхности растений привело к увеличению содержания сухих растворимых веществ в мякоти плодов на 12,6 \%, в сравнении с вариантом без применения.

Полученные семена дыни сорта Славия имели высокие посевные качества, однако отмечено, что с увеличением кратности обработок снижается энергия и всхожесть семян.

Растения дыни быстро наращивает вегетативную массу, поэтому необходимо планировать кратность обработки препаратом Зеромикс 3000 ррm, чтобы повысить биологическую эффективность его применения и исключить токсическое воздействие на растение и семена.

Применение препарата Зеромикс 3000 ppm coвместно с органо-силиконовым суперсмачивателем Мадже Стик обеспечило комплексную защиту растений от грибковых и бактериальных болезней, увеличение урожайности плодов и семян посевах дыни сорта Славия.

\section{ЛИТЕРАТУРА}

1. Дютин, К.Е. Проблема первичного семеноводства бахчевых культур / К.Е. Дютин // Материалы науч.-практ. конф. в рамках II фестиваля «Российский арбуз», 28-29 августа 2003 года. - С. 4-8.

2. Сирота, С.М., Проблемы системы семеноводства овощных культур в России и пути их решения / С.М. Сирота, В.Ф. Пивоваров // Международ. Науч.-практич. Конф. Современные тенденции в селекции и семеноводстве овощных культур. Традиции и перспективы 4-6 августа 2008г. // ВНИИССОК. -М, 2008. - Т. 2. - С. 32-42.

3. Радчевский, П.П. Управление величиной и качеством урожая винограда сорта Виорика путем применения регулятора роста Зеребра Агро / П. П. Радчевский, А. В. Брыкалов, О. И. Скорубская, Ю. И. Кандауров, А. А. Чич // НАУЧНЫЕ ТРУДЫ СКФНЦСВВ.- Т. 18. - 2018. - С. 69-75.

4. Кормин, В.П. Эффективность применения регулятора роста «Зеребра-Агро» на урожайность и качество зерна яровой пшеницы «Дуэт» в условиях лесостепи Западной Сибири / В.П. Кормин, Н.В. Гоман, Л.М. Лихоманова, М.А. Склярова, С.С. Мельникова // Электронный научно-методический журнал Омского государственного аграрного университета(ISSN2413-4066). - №3(6). - июль - сентябрь. - 2016.

5. Жеребин, П.М. Препарат «Зерокс» на основе химически модифицированного высокодисперсного серебра как элемент эффективной борьбы с бактериальными и грибными эпифитотиями сельскохозязяйственно значимых растений / П.М. Жеребин, А.Н. Игнатов, С.Н. Еланский, М.А. Побединская, Г.В. Лисичкин, А.Н. Денисов, Ю.А. Крутяков // Защита картофеля. - 2014. - № 2. - С. 43-45.

6. Шаповал, О.А. Влияние препаратов роста растений нового поколения на рост и продуктивность растений сои / О.А. Шаповал, И.П. Можарова, М.Т. Мухина // Плодородие. - 2015 - № 5 (86). - С. 22-28.

7. Левина, Л.А. Повышение эффективности производства подсолнечника на основе применения инновационных приемов в технологии возделывания на примере ООО «Прогресс» Сасовского района Рязанской области/ Л.А. Левина, Е.А. Строкова // Сборник материалов межвузовской научно-практической конференции "Актуальные вопросы современной аграрной экономики", ФГБОУ ВО РГАТУ, г. Рязань. - 2020. - С. 59-66.

8. Литвинов, С.С. Методика опытного дела в овощеводстве / С.С. Литвинов - М., - 2011. - 648 с.

9. Цыбулевский, Н.И. Бахчевые культуры (рекомендации) / Н.И. Цыбулевский, Е.М. Кулиш, Л.А. Шевченко. Краснодар: 2009. -34 с.

10. Литвинов, С.С. Методика опытного дела в овощеводстве / С.С. Литвинов - М., - 2011. - С. $244-247$.

11. Шеуджен, А.Х. Агрохимические основы применения удобрений / А.Х. Шеуджен, Т.Н. Бондарева, С.В. Кизинек. - Майкоп: Полиграф-Юг. - 2013. - 271 с.

12. Anh-Tuan LeA, Synthesis of oleic acid-stabilized silver nanoparticles and analysis of their antibacterial activity / Anh-Tuan Le ${ }^{A}$ Le ThiTama, Phuong DinhTamª, P. THuy ${ }^{a}$, Tran QuangHuy, NguyenVan Hiеu ${ }^{\mathrm{c}}$, А. Кудринский ${ }^{\mathrm{d}}$, Үu. А. Крутяков $^{d}$ // Materials Science and Engineering: C Volume 30, Issue 6, 20 July. - 2010.- P. 910-916.

13. Kudrinskiy A. A. The Mode of Action of Silver and Silver Halides Nanoparticles against Saccharomyces cerevisiae Cells / A. A. Kudrinskiy, A. Yu. Ivanov, E. V. Kulakovskaya, A. I. Klimov, P. M. Zherebin, D. V. Khodarev, Anh-Tuan Le, Le Thi Tam, G. V. Lisichkin, and Yu. A. Krutyakov // Hindawi Publishing Corporation Journal of Nanoparticles Volume 2014, Article ID 568635, 7 pages

\section{REFERENCES}

1. Dyutin, K.E. The problem of primary seed production of melons and gourds / K.E. Dyutin // Materials of scientific-practical. conf. within the framework of the II Festival "Russian Watermelon", August 28-29. - 2003. - P. 4-8.

2. Sirota, SM, Problems of the system of seed production of vegetable crops in Russia and ways to solve them / SM. Sirota, V.F. Pivovarov // International. Scientific and practical Conf. Modern trends in selection and seed production of 
vegetable crops. Traditions and perspectives August 4-6, 2008 // VNIISSOK. -M. - 2008. - V. 2. - P. 32-42.

3. Radchevsky, P.P. Management of the size and quality of the grape harvest Viorica using the Zerebra growth regulator by means of Agro / P. P. Radchevsky, A. V. Brykalov, O. I. Skorubskaya, Yu. I. Kandaurov, A. A. Chich // SCIENTIFIC WORKS SKFNTSSVV, V. 18. - 2018. - P. 69-75.

4. Kormin, V.P. Efficiency of application of the growth regulator "Zerebra-Agro" on the yield and grain quality of spring wheat "Duet" in the conditions of the forest-steppe registration of Siberia / V.P. Kormin, N.V. Goman, L.M. Likhomanova, M.A. Sklyarova, S.S. Melnikova // Electronic scientific and methodological journal of Omsk State Agrarian University (ISSN2413-4066). - July - September. - 2016. - № 3 (6).

5. Zherebin, P.M. The drug "Zerox" based on chemically modified dispersed silver as an effective fight against bacterial and fungal epiphytotes of agriculturally significant plants. Zherebin, A.N. Ignatov, S.N. Elansky, M.A. Pobedinskaya, G.V. Lisichkin, A.N. Denisov, Yu.A. Krutyakov // J. Potato Protection. - 2014. - № 2. - P. 43-45.

6. Shapoval, O.A. The influence of new generation plant growth preparations on the growth and productivity of soybean plants / O.A. Shapoval, I.P. Mozharova, M.T. Mukhina // f. Fertility. - 2015. - № 5 (86). - P. 22-28

7. Levina, L.A. Increasing the efficiency of sunflower production based on the use of innovative techniques in cultivation technology on the example of Progress LLC, Sasovsky district, Ryazan region / L.A. Levina, E.A. Strokova // Collection of materials of the interuniversity scientific-practical conference "Topical issues of modern agrarian economy", FGBOU VO RGATU, Ryazan. - 2020. - P.59-66.

8. Litvinov, S.S. Experimental methodology in vegetable growing / S.S. Litvinov - M. - 2011.- 648 p.

9. Tsybulevsky, N.I. Melons cultures (recommendations) / N.I. Tsybulevsky, E.M. Kulish, L.A. Shevchenko. - Krasnodar.- 2009. -34 p.

10. 10. Litvinov, S.S. Experimental methodology in vegetable growing / S.S. Litvinov - M., - 2011 .- P. $244-247$.

11. Sheujen, A.Kh. Agrochemical basis for the application of fertilizers / A.Kh. Sheujen, T.N. Bondareva, S.V. Kizinek. Maykop: Polygraph-Yug. - 2013.- 271 p.

12. An-Tuan Le A. Synthesis of silver nanoparticles stabilized with oleic acid, and analysis of their antibacterial activity / An-Tuan Le A. Le Thitama, Phuong Dinh Tama, P. Tuya, Tran Quang Huib, Nguyen Van Huyk, A. Kudrinsky, Yu.A. Krutyakovd // Materials Science and Engineering: C Volume 30, Issue 6, July 20. - 2010.- P. 910-916.

13. Kudrinsky A.A. The mechanism of action of silver nanoparticles and silver halides on the cells of Saccharomyces cerevisiae / A.A. Kudrinsky, A. Yu. Ivanov, E.V. Kulakovskaya, A.I. Klimov, P.M. Zherebin, D.V. Khodarev, An-Tuan Le, Le Thi Tam, G.V. Lisichkin, Yu.A. Krutyakov // Journal of Hindawi Publishing Corporation on nanoparticles, volume 2014, article ID 568635. - 7 p.

\section{Лазько Виктор Эдуардович}

Ведущий научный сотрудник лаборатории

бахчевых и луковых культур

E-mail: lazko62@mail.ru

\section{Якимова Ольга Владимировна}

Научный сотрудник лаборатории бахчевых и луковых культур

E-mail: belyaeva12092013@yandex.ru

Bсе: ФГБНУ «ФНЦ риса»

350921, Россия, г. Краснодар, пос. Белозерный, 3

\section{Благородова Елена Николаевна \\ Доцент кафедры овощеводства}

ФГБОУ КубГАУ имени И.Т. Трубилина

350044, Россия, г. Краснодар, ул. Калинина, 13

\section{Lazko Victor Eduardovich}

Leading researcher of the laboratory of melon and onion crops

E-mail: lazko62@mail.ru

\section{Yakimova Olga Vladimirovna}

Researcher of the laboratory of melon and onion crops

E-mail: belyaeva12092013@yandex.ru

All: FSBSI «FSC of rice»

3, Belozerny, Krasnodar, Russia, 350921

\section{Blagorodova Elena Nikolayevna \\ Associate professor}

FGBOU KubSAU named after I.T. Trubilin 13, Kalinina st., Krasnodar, Russia, 350044 


\section{ЭКОЛОГИЧЕСКИЙ РИСК РАСПРОСТРАНЕНИЯ НА РИСОВЫХ ПОЛЯХ СОРНЫХ РАСТЕНИЙ, УСТОЙЧИВЫХ К ГЕРБИЦИДАМ. ОБЗОР}

В обзоре представлена информация об исследованиях ученых разных стран мира, посвященных возникновению резистентности растений к химическим препаратам, применяющимся с целью уничтожения сорняков на рисовых полях. Обобщены сведения об основных группах сорных растений, распространенных во многих рисосеющих регионах, указаны биоэкологические особенности наиболее вредоносных видов. Обсуждаются вопросы, связанные с проведением фитосанитарного мониторинга, диагностики и обоснованием выбора химического метода борьбы с сорняками. Приведен перечень основных гербицидов, применяемых на рисовых полях Российской Федерации, с указанием их действующих веществ и принципа действия. По данным ученых ведущих рисосеющих стран мира описаны причины и последствия формирования устойчивых к гербицидам популяций сорных растений. Отмечается экологический риск от внедрения в ряде стран сортов риса, устойчивых к гербицидам. Показано, что в настоящее время повсеместно регистрируются биотипы злаковых растений рода Echinochloa, обладающие множественной и перекрестной устойчивостью по отношению к наиболее распространенным гербицидам группы ALS-ингибиторов. Проведен анализ результатов научных исследований по выявлению механизмов устойчивости на биохимическом и генетическом уровнях. Обсуждаются предложения по преодолению резистентности сорняков к гербицидам. Всестороннее изучение принципа действия и токсичности применяемых гербицидов, механизмов развития резистентности сорных растений важно для определения источников и факторов экологического риска. Подчеркивается необходимость применения комплексных мероприятий, включая не только химические, но также агротехнические и агроэкологические, для защиты растений риса от сорняков, устойчивых к гербицидам, и стабилизации экологической ситуации в зонах рисосеяния.

Ключевые слова: рис, сорные растения, Echinochloa, гербициды, ALS-ингибиторы, резистентность, перекрестная устойчивость, множественная устойчивость, экологический риск.

\section{ECOLOGICAL RISK OF HERBICIDE-RESISTANT WEEDS DISTRIBUTION IN RICE FIELDS. OVERVIEW}

The review provides information on studies by scientists from around the world on the emergence of plant resistance to chemicals used to kill weeds in rice fields. The information on the main groups of weeds common in many rice-growing regions is generalized, and the bioecological characteristics of the most harmful species are indicated. Issues related to phytosanitary monitoring, diagnostics and substantiation of the choice of a chemical method of weed control are discussed. A list of the main herbicides used in the rice fields of the Russian Federation is provided, with an indication of their active ingredients and the principle of action. According to scientists from the leading rice-growing countries of the world, the causes and consequences of the formation of herbicide-resistant populations of weeds are described. There is an environmental risk due to the introduction of herbicide-resistant rice varieties in some countries. It has been shown that biotypes of cereal plants of the genus Echinochloa are now being registered everywhere possessing multiple resistance and cross resistance to the most common herbicides of the ALS-inhibitor group. The analysis of the results of scientific research to identify the mechanisms of resistance at the biochemical and genetic levels has been performed. Proposals for overcoming the resistance of weeds to herbicides are discussed. A comprehensive study of the principle of action and toxicity of the herbicides used, the mechanisms of the development of weeds resistance is important for determining the sources and factors of environmental risk. The need to apply complex measures, including not only chemical, but also agrotechnical and agroecological, to protect rice plants from weeds resistant to herbicides, and to stabilize the ecological situation in rice growing areas, is emphasized.

Key words: rice, weeds, Echinochloa, herbicides, ALS-inhibitors, resistance, cross resistance, multiple resistance, environmental risk.

Система оценки экологического риска используется для управления состоянием окружающей среды и прогнозирования развития экологической ситуации, складывающейся под воздействием антро- погенной деятельности. Оценка риска необходима в случае химического давления на экосистемы, в том числе при ведении сельского хозяйства по интенсивным технологиям. Такие технологии при- 
меняются и в рисоводстве, являясь как экономически оправданными, так и экологически непредсказуемыми. Поэтому в данном случае речь идет о разработке стратегии рационального аграрного природопользования с учетом оценки воздействия на окружающую природную среду и здоровье человека. Приемлемый риск содержит технические, экологические, политические и социальные аспекты и представляет собой компромисс между приемлемым уровнем экологической безопасности и экономическими возможностями его достижения.

Биотические факторы среды - это неотъемлемая часть любых нормально функционирующих экосистем, как природных, так и антропогенно преобразованных. К их числу относятся и все организмы, негативно влияющие на урожай культурных растений. Для контроля их численности, как правило, используются химические средства защиты растений - пестициды, объемы применения которых часто неоправданно велики и создают определенные риски как для элементов агроэкосистем, так и для здоровья человека. И если в начале XXI века для защиты растений от болезней начинают применять препараты нового поколения - биофунгициды и активно внедрять методы биологической защиты от вредителей, то в случае борьбы с сорняками по-прежнему основным методом остается химическая защита растений.

Современная концепция интегрированной защиты растений предполагает сочетание агротехнических (севообороты, разные способы механической обработки почвы), биологических и химических методов борьбы с сорняками [1]. Химический метод, заключающийся в обработке посевов гербицидами, должен применяться на полях только в том случае, если агротехническими приемами снизить засоренность полей не удается. Широкое использование некоторых препаратов нового поколения вопреки нормативам и научно обоснованным оптимальным технологиям недопустимо из-за их высокой фитотоксичности [4]. Бесконтрольное применение гербицидов в растениеводстве в целом, и в рисоводстве в частности, влечет за собой серьезные проблемы: загрязнение окружающей среды, снижение биоразнообразия, нарушение экологического равновесия, появление устойчивых популяций сорных растений.

Фитосанитарный мониторинг рисовых полей проводится на регулярной основе с целью установления экономического порога вредоносности сорных растений для разработки экономически обоснованных мероприятий по контролю численности их популяций, подбора необходимых гербицидов и установления кратности обработок химическими препаратами.

Исторически применение гербицидов при возделывании риса на Кубани относится к началу 30-х годов XX века. Обследование рисовых полей, ис- пользуемых здесь с 1938 г., показало, что в пахотном слое в расчете на 1 м² содержалось 2,97 тыс. шт. семян просовидных сорняков, клубней 0,2 тыс. шт. клубнекамыша, 32,52 тыс. шт. частухи, сусака и др. Лучшие результаты по уничтожению просовидных сорняков в те годы были достигнуты при опрыскивании растений 3 \% раствором хлората кальция, а многолетние широколистные сорняки подавляли внесением 3-5 \% раствора этого химиката в почву [11]. При этом, по мнению ведущего специалиста в СССР по сорным растениям рисовых полей И. С. Косенко (1940), применение гербицидов для защиты посевов риса от сорняков можно рассматривать только как вспомогательное средство даже при положительных результатах опытов, а основной упор необходимо делать на агротехнические мероприятия. Такое утверждение было связано, в первую очередь, с тем, что в тот период не было эффективных селективных гербицидов, избирательно действующих не на растения риса, а только на сорняки, особенно на однолетние злаки, сходные с культурным рисом по систематической принадлежности и жизненной форме. В то же время, с экологической точки зрения заслуживает внимания предложение ученого по задернению валиков и берегов каналов луговыми травами для предотвращения размывания поверхности почвы вместо выкашивания и обработок гербицидами растений местной флоры (тростника, рогозов) на этих местообитаниях.

В 60-е годы XX в. химический метод борьбы с сорняками риса применяется все шире и приходит на смену малопроизводительной в производственных условиях и дорогостоящей ручной полке. Для контроля численности просовидных сорняков на рисовых полях в СССР применяли контактные гербициды группы 3,4-Д, например, Стам Ф-34 (д.в. пропанил), а для подавления широколистных сорняков - системные гербициды 2,4-Д и 2М-4X. Этот метод позволил поднять к 1971 г. урожайность риса по стране до 36,6, а на Кубани - до 47 ц/га и был признан высокоэффективным [2].

В последующие годы ассортимент препаратов расширялся, в рисоводстве внедрялись интенсивные технологии производства риса, предполагающие не только получение высоких урожаев, но и увеличение химической нагрузки на компоненты агроэкосистем и ухудшение экологической ситуации в зоне рисоводства.

$\mathrm{K}$ началу XXI века в мировом масштабе $\mathrm{OOH}$ начинает оценку экосистем на пороге нового тысячелетия. Основное внимание обращается на услуги, обеспечиваемые экосистемами, и на возможное воздействие экосистемных изменений на людей в будущие десятилетия. Обсуждаются также варианты мер реагирования, которые можно было бы принять на локальном, национальном или глобальном уровнях в целях усовершенствования управления экосистемами. 
На Втором глобальном форуме ФАО/ВОЗ сотрудников органов по обеспечению продовольственной безопасности (Бангкок, Таиланд, 12-14 октября 2004 года) обсуждались экологические риски, связанные как с традиционными методами ведения сельского хозяйства, так и с внедрением новых биотехнологий. В ходе работы над индикаторами санитарного состояния окружающей среды было выявлено, что различные методы ведения сельского хозяйства оказывают через экологические последствия прямое или косвенное воздействие на здоровье людей. Угрозы могут принимать самые разные формы и возникать совершенно естественно или быть результатом антропогенного воздействия [42]. В докладе Форума отмечалось, что к числу потенциальных рисков для окружающей среды относится непредвиденное воздействие на нецелевые организмы, экосистемы и биоразнообразие. Таким образом, на глобальном уровне был признан экологический риск появления сорняков, устойчивых к гербицидам, получивших название «суперсорняки».

Еще одним существенным фактором риска на полях разных стран мира, где осуществляется коммерческое возделывание культурных геномодифицированных растений, включая рис, является ауткроссинг трансгенов [23]. Ауткроссинг (перекрестное опыление) может приводить к передаче нежелательных генов, таких как гены резистентности к гербицидам, нецелевым культурам или сорнякам, создавая новые проблемы в борьбе с сорными растениями. Поэтому необходима предварительная серьезная оценка экологического риска, связанного с коммерческим использованием трансгенных сортов однолетних культур, в том числе и риса. Такая оценка нашла отражение в обзорах, представленных учеными разных стран [31, 50].

Впервые новый метод борьбы с сорной растительностью, сущность которого состоит в создании сортов риса, устойчивых к гербицидам, был разработан в США. Суть метода заключалась в создании генетически модифицированных или мутантных растений риса, обладающих устойчивостью к гербицидам. Посевы таких сортов в течение вегетации без ущерба для урожая культуры можно обрабатывать гербицидами, поставляющимися сельхозпроизводителям вместе с семенами риса. При этом контролируется численность популяций сорных растений, включая сорно-полевые формы краснозерного риса. Однако не были учтены все риски, с которыми пришлось столкнуться тем, кто начал возделывать подобные сорта.

После внедрения в производство трансгенных сортов риса, в том числе обладающих геном устойчивости к гербициду глюфосинату (gluphosinate), были зарегистрированы случаи перекрестного опыления с экотипами краснозерного риса с образованием устойчивых к гербициду краснозерных гибридных растений риса [50]. Впоследствии механизм дрейфа генов между трансгенными сортами риса и краснозерными сорно-полевыми формами был изучен для оценки экологического риска и определения частоты появления устойчивых к глюфосинату растений краснозерного риса в гибридных популяциях разных поколений [44].

Внедрение трансгенных сортов риса, тем не менее, позволяло бороться с наиболее злостными просовидными сорняками, такими как представители рода Echinochloa Beauv., которые в результате постоянного селективного давления уже успели развить устойчивость к традиционно применяемым в рисоводстве гербицидам [6]. Так, интенсивное и регулярное использование пропанила на посевах риса в США в течение 30 лет привело к появлению устойчивых к нему биотипов куриного проса (Echinochloa crus-galli (L.) Beauv.). Впервые резистентные к пропанилу растения куриного проса были отобраны в 1990 г. Изучение их методом RAPD-анализа выявило множественный вид устойчивости, обусловленный несколькими независимыми мутациями [40]. В дальнейшем эксперименты показали, что устойчивые к пропанилу растения подавлялись более чем на 90 \% другими гербицидами, в частности IMI (д. в. imazethapyr - имазетапир), коммерческое название Newpath (технология Clearfield (CL) - «Чистое поле»). Их применяли как до посева риса, так и по слою воды через 56 дней после посева [32]. Без проведения таких обработок альтернативными гербицидами урожайность риса составляла всего 1,5 т/га.

Для определения источников и факторов экологического риска, связанного с развитием резистентности, необходимо всестороннее изучение принципа действия и токсичности применяемых гербицидов, а также причин и последствий появления на рисовых полях сорных растений, устойчивых к гербицидам.

В первое десятилетие XXI в. рекомендуемыми для применения в отрасли рисоводства в Российской Федерации были послевсходовые противозлаковые гербициды Фацет (д. в. квинклорак), Стомп (д. в. пендиметалин), Аура плюс (д. в. клефоксидим), Шаккимол и Ордрам (д. в. молинат). Для уничтожения широколистных сорняков были рекомендованы Агритокс, ВК (д. в. МЦПА), Базагран (д. в. бентазон), Лондакс, СТС (аризон) (д. в. бенсульфурон-метил), Сириус, СП (д. В. пиразосульфурон-метил), Номини, СК (д. в. биспирибак натрия) [16]. Эти гербициды содержали действующие вещества с разным принципом действия [3]. Некоторые из них до сих пор применяют для борьбы с сорняками риса, при этом их внесение должно строго регламентироваться на основе порога вредоносности.

Современный ассортимент гербицидов отличается высокой биологической эффективностью и широким спектром активности по отношению к 
основным видам растений, засоряющим посевы риса. По отношению к компонентам окружающей среды они считаются малоопасными. Наиболее востребованы при производстве риса в южных регионах России в настоящее время и разрешены для применения следующие гербициды: Номини, СК (д. в. биспирибак натрия), Нарис, СК (д. в. биспирибак кислота), Сегмент, ВДГ (д. в. азимсульфурон), Цитадель 25 (Цитата, МД и Крепошанс, МД - до 2020 г.) (д. в. пеноксулам), Оризан, МСК (д. в. бенсульфурон-метил), Сириус, СП (д. в. пиразосульфурон-метил), Базагран, ВР и Корсар, ВРК (д. в. бентазон).

Несмотря на разные действующие вещества, большинство гербицидов, используемых на рисовых полях в РФ, относится к одной и той же группе «В» согласно классификации HRAC (Herbicide-Resistance Action Committee), принятой с 1991 г. в большинстве стран мира, или группе «2» (классификация WSSA, принятая в США и Канаде). В Австралии существует собственная система классификации. Все эти препараты имеют один и тот же принцип действия и являются ингибиторами ацетолактатсинтазы (ALS-ингибиторы). Гербициды с таким механизмом действия были разработаны и предложены производству с 1980-х гг. Перечень коммерческих названий гербицидов группы B/2 и их действующих веществ приведен на сайте http:// www.weedscience.org/Summary/Herbicide.aspx. Иcключение составляют Базагран и Корсар, в основном применяемые для подавления растений клубнекамыша и относящиеся к группе С3 (HRAC) или 7 (WSSA). Они являются ингибиторами фотосинтеза фотосистемы II.

В некоторых случаях на сильно засоренных однолетними злаковыми сорняками рисовых полях Кубани применяют гербициды группы A (HRAC) или 1 (WSSA), являющиеся ингибиторами ацетил-КоА карбоксилазы (АСС-ингибиторы): Фокстрот, Пума, Ирбис (д. в. феноксапроп-П-этил - fenoxaprop-P-ethyl). Гербициды данной группы были разработаны с 1970-х гг. и вышли на рынок к середине 80-х гг. XX в. Однако, как известно, эти гербициды успешно применяются на посевах колосовых зерновых, а на растения риса действуют угнетающе из-за высокой фитотоксичности. Поэтому сейчас предпринимаются попытки снизить токсическое действие феноксапроп-П-этила добавлением антидота изоксадифен-этила (isoxadifen-ethyl) и использовать препараты для борьбы с краснозерным рисом [43]. Для успешного применения этих гербицидов на рисовых полях необходимы дополнительные исследования.

Инновационным решением стало создание системного гербицида нового поколения Номини Суприм, СЭ, сочетающего два действующих вещества разных по принципу действия: метамифоп (группа A/1) и биспирибак натрия (группа B/2). Гер- бицид предназначен для борьбы с сорняками риса всех типов, а именно: злаковых, осоковых и широколистных.

Еще одним химическим способом контроля на сильно засоренных участках является использование различных вариантов баковых смесей гербицидов с разными действующими веществами. Сложность такого подхода заключается в том, что произвольные сочетания без предварительных испытаний могут дать непредсказуемый эффект и вызвать задержку роста и повреждение растений культуры. Экологический риск для многокомпонентных агроэкосистем в этом случае возрастает.

Главным принципом при выборе любого гербицида или их сочетания должен быть приоритет фитосанитарной диагностики в каждом конкретном случае [1]. Первоначальной задачей такой диагностики является определение видовой принадлежности сорных растений, численности и плотности их популяций для установления экономического порога вредоносности.

Видовой состав сорняков риса своеобразен и связан с особыми экологическими требованиями культуры. По данным П. И. Костылева и К. С. Артохина (2010) посевы риса на юге России засоряют около 50 видов высших растений, относящихся к разным экологическим группам по отношению к влажности [12]. Это связано с тем, что рис здесь возделывают в режиме затопления в течение вегетационного периода. В экологической структуре сегетальной флоры рисовых полей Кубани к 2010 г. по отношению к водному режиму было выявлено 38 \% гигрофитов, 32 \% гидрофитов, 9 \% мезофитов. Остальные растения (21\%), такие как тростник южный (доминант-эдификатор Приазовских плавней), горец земноводный, частухи и рогозы обладают высокой экологической пластичностью и занимают промежуточное положение, являясь гигрофитами или гидрофитами в зависимости от сложившихся условий увлажнения [5]. Знания экологических требований сорных растений по отношению к увлажнению почвы необходимы для разработки методики внесения гербицида (так как это часто связано со сбросом воды с чеков или понижением уровня воды), а также при создании безгербицидных технологий возделывания риса.

С 2017 г. на рисовых полях Кубани были зарегистрированы новые адвентивные сорные растения болотного типа в дополнение к ранее составленному флористическому списку $[8,9]$. Это виды рода аммания - Ammannia auriculata Willd. (аммания ушастая) и Ammannia coccinea Rottb (аммания шарлаховая) семейства Lythraceae (Дербенниковые) и вид Lindernia dubia (L.) Pennell - линдерния сомнительная семейства Scrophulariaceae (Норичниковые). Они относятся к группе так называемых широколистных сорняков и имеют высокий инвазионный потенциал. Для борьбы с ними необходимо 
выработать новую системную стратегию, включающую как агротехнические, так и химические методы с учетом их биоэкологических особенностей. Распространение этих сорных растений на полях Кубани, вероятно, связано с тем, что они поздно начинают вегетацию и «уходят» от общепринятой обработки посевов риса гербицидами, активно развиваясь и конкурируя с рисом в июле-августе, когда применение гербицидов без ущерба для культурного риса уже невозможно.

Возможность формирования резистентности к гербицидам новых для рисовых полей Кубани сорных растений подтверждена учеными других стран. Результаты представлены на сайте http:// www.weedscience.org Международной базы данных сорняков, устойчивых к гербицидам. Так, в Калифорнии, США, были зарегистрированы устойчивые к ALS-ингибитору бенсульфурон-метилу (д. в. применяемых в нашей стране препаратов Лондакс и Оризан) растения аммании ушастой (1997 г.) и аммании шарлаховой (2000 г.). В 2004 г. резистентные к тому же гербициду растения а. шарлаховой обнаружили и в Японии. Что же касается линдернии сомнительной, то популяции, устойчивые к бенсульфурон-метилу, регистрировались в 1995 г. в Японии, а в 2000 г. - в Южной Корее. В данном случае устойчивость была множественной и проявлена еще к 7 действующим веществам группы B/2, в том числе азимсульфурону (гербицид Сегмент) и пиразосульфурон-метилу (Сириус).

Для выбора стратегии контроля численности популяций сорных растений необходимо изучать не только их видовой состав и обилие, но и биологические особенности, и экологические требования [20].

По популяционно-репродуктивным особенностям сорные растения делятся на две резко различающиеся между собой группы: неспециализированные засорители посевов сельскохозяйственных культур и специализированные засорители. Большинство однолетних сегетальных растений рисовых полей являются неспециализированными сорняками. По сложности популяций, способности размножаться и распространяться без помощи человека, огромной плодовитости, разновременности созревания семян, их осыпаемости и разнокачественности, неравномерному прорастанию, чрезвычайно высокому воспроизводству, развитию мощной корневой системы они являются типичными дикорастущими растениями. Все эти и многие другие признаки, сближающие их с дикорастущими, на фоне общих с культивируемыми растениями экологических условий пашни способствуют устойчивому и постоянному существованию сорно-полевых растений этой группы в посевах сельскохозяйственных культур [17].

Среди таких растений часто встречаются виды-космополиты и гемикосмополиты, занимаю- щие огромные ареалы, например, Cyperus difformis L. (сыть разнородная) и Echinochloa crus-galli (L.) Beauv. (ежовник обыкновенный, куриное просо). Оба эти вида засоряют посевы риса большинства стран мира, постоянно служат мишенью при защите культуры от сорняков. Вследствие этого они приобрели устойчивость к наиболее часто применяемым на рисовых полях гербицидам, в том числе ныне используемым гербицидам группы В/2 [22, 33, 37, 46].

Популяции неспециализированных однолетних сегетальных растений устойчивы к любым воздействиям на них человека и продолжают успешно конкурировать с рисом, несмотря на все применяемые методы борьбы с ними. Однако на ранней стадии развития растения E. crus-galli чувствительны к толщине слоя воды свыше 15 см. Эта экологическая особенность куриного проса лежит в основе безгербицидной технологии, пригодной для санитарно-защитных зон [10]. Подобные технологии снижают экологические риски при возделывании риса вблизи населенных пунктов и в водоохранных зонах.

Специализированные однолетние виды сорных растений сходны с культивируемыми не только по экологическим, но и по популяционно-репродуктивным особенностям. Они существуют в настоящее время в основном на полях лишь самых древних культурных растений: риса, пшеницы, ржи, овса и льна.

Специализированными засорителями риса являются Echinochloa oryzoides (Ard.) Fritsch (ежовник рисовидный) и Echinochloa phyllopogon (Stapf) Kossenko, или Echinochloa oryzicola Vasing (ежовник бородчатый, или рисовый) семейства Роасеае (Мятликовые). В составе естественных фитоценозов они не встречаются и существуют только на рисовых полях. Растения этих видов ближе всего к рису по своей экологии, устойчивы к глубокому затоплению даже в первые фазы вегетации, в отличие от ежовника обыкновенного [7]. Семена их не имеют периода покоя и прорастают в первый же год почти на $100 \%$ с глубины 10-15 см. В почве хорошо сохраняют всхожесть в течение 5 лет [11]. Как и специализированные сорняки других сельскохозяйственных культур, они следуют за культурой риса из Юго-Восточной Азии во все вновь осваиваемые районы, не внедряясь в природные экосистемы. В связи с постоянным давлением в результате химических обработок посевов эти виды ежовников в некоторых странах приобрели резистентность к часто применяемым препаратам, например с д. в. тиобенкарб (гербицид Сатурн) [36] и д. в. биспирибак натрия (Номини) [25].

Согласно определению HRAC устойчивость сорных растений к действию гербицидов - это стабильное состояние, при котором влияние гербицида на популяцию сорняков приводит к доминированию 
генотипов, способных выживать и расти после обработки гербицидом в тех концентрациях, которые при нормальных условиях губительны для популяции. Первоначально устойчивость к применяемому гербициду проявляется у отдельных наименее восприимчивых к нему сорных растений, число которых тем выше, чем больше гетерогенность популяции. Повторное применение данного гербицида, либо гербицида с иным действующим веществом, но идентичным механизмом действия приводит к селективному отбору резистентных сорных растений. В отсутствии других методов борьбы, кроме химических, а также при нарушении севооборотов такие растения быстро увеличивают численность популяции. В определенных агроэкологических ситуациях, например, при очень высокой засоренности полей, возникает необходимость увеличивать кратность применений гербицидов. Однако многократная обработка узкоизбирательными гербицидами способствует появлению резистентных видов сорняков, что в последующих посевах требует повышенных норм применения этих препаратов либо их смесей, что создает дополнительные риски для окружающей среды.

Рассмотрим основные аспекты проблемы резистентности к гербицидам на примере развития разных типов устойчивости злостных сорняков риса и их механизмов.

Растения риса относительно устойчивы к действию пропанила, но большинство сорняков чувствительны к нему. Поэтому препараты с этим действующим веществом, начиная с 1960-х годов, активно применялись на посевах риса во многих странах против широколистных сорняков болотного типа. Тогда как гербициды с д. в. квинклорак (Фацет) регулярно использовали против просовидных сорняков. Это способствовало распространению на полях сорных растений, резистентных к этим препаратам.

Подтверждением служат опыты, проведенные на рисовых полях Малайзии. Десять популяций $E$. crus-galli обрабатывали гербицидами: пропанилом и квинклораком. Оказалось, что 9 из 10 изученных популяций проявили устойчивость к пропанилу и одна из 10 - к квинклораку. Для борьбы с растениями популяций E. crus-galli авторами рекомендуется применение баковых смесей не менее двух гербицидов [39]. Но такой вариант существенно увеличивает экологическую нагрузку на компоненты агроэкосистемы.

Изучению механизмов устойчивости к синтетическому ауксину квинклораку (группа О/4) популяций E. crus-galli, обнаруженных на рисовых полях разных провинций Китая, посвящены исследования P. Qiong и сотр. (2019). Они зарегистрировали у резистентных популяций 78-кратное превышение порога устойчивости по сравнению с чувствительными к гербициду растениями [38]. Анализ биохи- мических процессов у устойчивых к квинклораку растений куриного проса, проведенный учеными разных стран, выявил, что механизм устойчивости связан с ингибированием биосинтеза этилена и цианидов [47, 48]. Аналогичный результат был получен японскими учеными и для устойчивых $\mathrm{K}$ квинклораку биотипов E. phyllopogon [21].

Растения разных видов рода Echinochloa приобрели резистентность и к одному широко распространенному гербициду группы ALS-ингибиторов с д. в. пеноксулам (в РФ использовались препараты с этим д. в. под коммерческими названиями Цитадель, Цитата, Крепошанс). J. Fang и сотр. (2019) сообщают о появлении на рисовых полях Китая популяций устойчивых к пеноксуламу растений $E$. crus-galli, летальная доза $L_{50}$ которых в 5,2-11 раз превышала дозу, необходимую для уничтожения растений, чувствительных к препарату [24]. Изучение механизмов резистентности к пеноксуламу растений другого вида - E. phyllopogon, проведенное той же группой китайских ученых, выявило мутацию Pro-197-Ser ALS-гена, приводящую к снижению эффективности воздействия препарата на устойчивые растения [29].

Как известно, различают два основных вида резистентности: групповую, или перекрестную (cross-resistance) и множественную (multiple resistance). При перекрестной резистентности растения устойчивы к двум или нескольким действующим веществам, относящимся к одной химической группе и близким по строению и механизму действия. Такая устойчивость обусловлена одним и тем же генетическим фактором. При этом возврат чувствительности растений возможен при чередовании препаратов различных химических групп. Перекрестная устойчивость может возникать между действующими веществами с одинаковым механизмом действия или даже между действующими веществами разных механизмов действия. Множественная резистентность наиболее опасна и означает устойчивость к двум или нескольким веществам разных химических групп. Она контролируется разными генетическими факторами в одном и том же растении. Эта резистентность часто возникает на основе усиления активности ферментов, разрушающих гербицид [19].

Перекрестная и множественная устойчивость наиболее распространенных и злостных сорняков риса к гербицидам фиксируется учеными с 1990-х годов, и в настоящее время сообщается о биотипах сорняков, устойчивых к действующим веществам большинства разрешенных к применению препаратов.

Сыть разнородная на рисовых полях Арканзаса, США, широко распространена и, так же как и просовидные сорняки, создает серьезные проблемы рисоводам. Р. Tehranchia и сотр. (2015) зафиксировали перекрестную устойчивость растений Су- 
perus difformis к галосульфурону (д. в. препарата из группы В/2). Исследованиями установлено, что резистентные растения были также устойчивы к трем другим действующим веществам препаратов этой группы: биспирибаку натрия, пеноксуламу и имазатоксу. Уровень устойчивости к этим гербицидам определялся по $\mathrm{LD}_{50}$. Оказалось, что для подавления резистентных растений сыти необходимо увеличить концентрацию гербицида в 15 раз и более по сравнению с растениями чувствительных биотипов. При этом растения как устойчивого, так и чувствительного биотипа сыти успешно подавлялись (более 96 \%) бентазоном и пропанилом, имеющими другой принцип действия и являющимися ингибиторами фотосинтеза фотосистемы II (группы С3/7 и С2/7 соответственно) [46].

О появлении на рисовых полях Филиппин растений E. crus-galli с множественной устойчивостью к двум гербицидам - бутахлору и пропанилу сообщили L. M. Juliano и сотр. (2010) [27].

На рисовых полях Арканзаса в США J. K. Norsworthy и сотр. (2014) зафиксировали популяцию E. crus-galli, устойчивую сразу к трем гербицидам группы 2 - ALS-ингибиторам с разными действующими веществами: пеноксулам, биспирибак натрия и имазетапир. Эти гербициды использовали на сортах риса, выращенных по технологии Clearfield. Причем для гибели 50 \% растений $\left(\mathrm{LD}_{50}\right)$ чувствительных биотипов ежовника необходимая доза биспирибака натрия составила 6 г/га, пеноксулама -10, имазетапира - 12 г/га. Тогда как для гибели того же числа устойчивых растений E. crus-galli необходима была многократно увеличенная доза этих препаратов до 49, 254 и 170 г/га соответственно [35].

Для решения проблемы преодоления устойчивости к гербицидам группы ALS-ингибиторов и дальнейшего продвижения технологии Clearfield, американские ученые разработали новый вариант технологии возделывания трансгенных сортов риса, применяемой с использованием гербицидов группы АСС-ингибиторов (ACCase-R rice technology) или смеси АСС-ингибиторов и синтетических ауксинов. В качестве действующего вещества используется ACC-ингибитор quizalofop-p-ethyl (группа $\mathrm{A} / 1)$ или его смесь с синтетическими ауксинами [41, 49]. Однако по примеру с результатом применения технологии Clearfield в сопровождении гербицидов группы ALS-ингибиторов можно в скором времени ожидать регистрации на рисовых полях резистентных популяций сорняков к АСС-ингибиторам.

На полях Уругвая было отобрано более 40 устойчивых к гербицидам биотипов E. crus-galli. Исследования были проведены в соответствии с протоколом HRAC и выявили наличие 35 биотипов, устойчивых к квинклораку, 7 - к пропанилу, 12 - к имазапиру и 3 - к пеноксуламу. При этом 5 биотипов проявили устойчивость одновременно к двум гербицидам - пропанилу и квинклораку, а один к трем гербицидам (квинклораку, пеноксуламу и имазапиру) [33].

Резистентные популяции сразу двух видов ежовников E. crus-galli и E. phyllopogon были зафиксированы на рисовых полях Южной Кореи. Растения этих видов проявили перекрестную устойчивость к трем препаратам группы B/2: азимсульфурону, пеноксуламу и биспирибаку натрия [45].

В Греции зафиксировали перекрестную устойчивость 29 популяций E. phyllopogon к пеноксуламу, биспирибаку натрия, имазатоксу и еще трем действующим веществам из разряда сульфонилмочевин, возникшую в результате мутации Trp574Leu. B свою очередь, все растения резистентных популяций успешно подавлялись АCC-ингибирующим гербицидом с действующим веществом профоксидим (profoxydim) [28]. Тогда как в Корее W. Q. Јіа и сотр. (2020) сообщили о множественной устойчивости популяций этого же вида ежовника одновременно к гербицидам групп ALS-ингибиторов и ACC-ингибиторов и изучили с помощью SSR-маркеров (simple sequence repeat) степень их распространения на рисовых полях страны [26].

Об устойчивых биотипах сорняков семейства Мятликовые в России, к сожалению, известно мало, но это объясняется слабой изученностью проблемы, а не ее отсутствием [13]. Исследования по выявлению устойчивых к гербицидам сорных злаков проводили в 2010-2018 гг. на рисовых полях Кубани и Дальнего Востока.

На посевах риса в Приморском крае в 2010 г. были зарегистрированы биотипы трех видов ежовников (E. crus-galli, E. occidentalis, E. phyllopogon), устойчивых к гербициду Фацет (д. в. квинклорак). Было показано развитие устойчивости растений этих видов при увеличении количества обработок в рисоводческих хозяйствах Приморского края [14]. Для преодоления устойчивости к квинклораку в последующих посевах применяли гербициды с другим механизмом действия - Нарис, Номини, Цитадель и Сегмент, действующие вещества которых сходны по механизму воздействия и являются ALS-ингибиторами. Однако в последние годы степень засоренности ежовниками возросла, практически на всех посевных площадях в Приморском крае появились растения, устойчивые к действию гербицидов.

Исследования Н. Г. Лукачевой и А. В. Костюк (2019) выявили биотипы ежовников, устойчивые к гербициду Сегмент (д. в. азимсульфурон, 500 г/кг). Признаки приобретенной резистентности регистрировались на пятый год применения препарата, и в дальнейшем с каждым годом доля биотипов ежовников, устойчивых к данному гербициду, резко увеличивалась. Доказано, что устойчивость ежовников к препарату Сегмент является перекрестной и развивается у биотипов с ранее выработанной 
резистентностью к гербициду Фацет. Определение $\mathrm{LD}_{50}$ для устойчивого $(\mathrm{R})$ и чувствительного биотипов (S) и расчет показателя резистентности выявил наиболее высокую степень устойчивости (61) биотипов вида E. crus-galli. У E. phyllopogon и $E$. occidentalis этот показатель составил 43 и 23 соответственно. Из-за отсутствия на производственных посевах риса на Дальнем Востоке гербицидов с другим механизмом действия авторы предлагают применять многовариантную тактику борьбы с сорняками с учетом химических, агротехнических и агроэкологических методов [15].

На рисовых полях Краснодарского края была зарегистрирована устойчивость растений рода Echinochloa к применяемым гербицидам группы B/2 (ALS-ингибиторы). В условиях полевого опыта О. А. Брагина (2016) выявила устойчивые к гербициду Цитадель 25 (д. в. пеноксулам) растения трех видов ежовников: (E. crus-galli, E. oryzoides, E. phyllopogon), семена которых были отобраны на производственных посевах в рисоводческих хозяйствах края. Отмечены быстрые темпы роста сорных растений после применения стандартной обработки гербицидом (1,6 л/га в фазе 4-5 листьев у ежовников, что говорит о формировании резистентных популяций сорных растений) [3].

Проведенный анализ литературных источников показал, что наиболее активны в изучении проблемы появления резистентных к гербицидам сорных растений на рисовых полях с целью разработки эффективной системы управления сорняками ученые США и Китая. В США это продиктовано необходимостью возделывания сортов риса по общепринятой системе Clearfild и использованием одних и тех же прилагаемых к сортам гербицидов. К тому же данная технология применяется в других странах, например, в Уругвае и Бразилии, где рисоводы сталкиваются с теми же проблемами [34]. Китай является мировым лидером по производству риса. Поэтому в Китае сейчас проводятся масштабные исследования по установлению механизмов множественной и перекрестной резистентности 26 видов основных сорняков риса к применяемым гербицидам разных групп: синтетическим ауксинам (группа О/4); АCС-ингибиторам (группа A/1); ALS-ингибиторам (группа B/2) [30].

В настоящее время научные исследования в области появления в посевах «суперсорняков», устойчивых к гербицидам, направлены на установление механизмов развития устойчивости и изуче- ние принципов их действия, а также на разработку стратегии преодоления устойчивости растений $\mathrm{k}$ гербицидам. В основном пути решения проблемы предлагаются следующие: использование альтернативных препаратов и применение гербицидов с разными действующими веществами из разных групп. Однако, как известно, существует ограниченное количество механизмов действия гербицидов, которые могут быть использованы в качестве замены. При этом в определенных случаях потенциал преодоления устойчивости к гербицидам уже достигнут. Разработка гербицидов с новыми механизмами действия - очень сложный процесс, поскольку становится все труднее найти новые действующие вещества, которые не оказывают отрицательного воздействия на соответствующие культуры и имеют достаточную экологическую совместимость. Из-за высоких затрат, связанных с исследованиями и регистрацией, разработка новых механизмов действия имеет смысл только в том случае, если эти гербициды могут использоваться во всем мире на основных сельскохозяйственных культурах. Но на мировом рынке преобладают трансгенные, устойчивые к гербицидам культуры, для которых узкоспециализированные гербициды не нужны. Поэтому за последние 30 лет не было введено в производство ни одного нового гербицидного механизма действия [18].

Исследования ученых разных стран подтверждают возрастание экологического риска для экосистем и здоровья человека в связи с тем, что хороший урожай риса на полях со смешанным типом засорения как просовидными, так и широколистными сорняками, может быть получен при химических обработках многократно возрастающих доз ныне применяемых гербицидов, считающихся малоопасными, либо возвратом к обработкам более токсичными препаратами предыдущего поколения.

Излишняя химизация, также как и трансгенное биозагрязнение агроэкосистем приводят к глубоким экологическим изменениям, дестабилизируют генофонды культурных и диких видов. Рациональное использование гербицидов, правомерный, научно обоснованный подбор препаратов, разработка комплексных программ управления сорной растительностью, приемы органического и точного земледелия, внедрение методов биологической защиты растений могут снизить негативное воздействие новых технологий возделывания риса на окружающую среду и снизить экологический риск. 


\section{ЛИТЕРАТУРА}

1. Артохин, К. С. Сорные растения / К. С. Артохин. - Ростов-на-Дону, 2004. - 144 с.

2. Борьба с сорняками риса / под ред. В. Д. Агаркова и др. - Москва: Колос, 1972. - 149 с.

3. Брагина, О. А. О резистентности сорняков к гербицидам / О. А. Брагина // Рисоводство. - Краснодар, 2016. № 1-2 (30-31). - С. 46-49.

4. Гулидов, А. М. О последействии гербицидов / А. М. Гулидов // Защита и карантин растений. - 2003. - № 2. - С. 25-26.

5. Зеленская, О. В. Анализ сегетальной флоры рисовых полей в дельте реки Кубань / О. В. Зеленская // Труды КубГАУ. - Краснодар, 2010. - Вып. №1 (22). - С.81-85.

6. Зеленская, О. В. К вопросу о возделывании сортов риса, устойчивых к гербицидам / О. В. Зеленская // Политематический сетевой электронный научный журнал Кубанского государственного аграрного университета (Научный журнал КубГАУ) [Электронный ресурс]. - Краснодар, 2011. - №03 (67). - Режим доступа: http: ej.kubagro. ru/2011/03/pdf/11.pdf . 0,75 у.п.л.

7. Зеленская, О.В.Динамика численности сорных растений семейства Роасеае на рисовых полях Кубани / О. В. Зеленская // Рисоводство. - Краснодар, 2019. - № 1 (42). - С. 37-42.

8. Зеленская, О. В. Сорные растения рода Lindernia All. на рисовых полях Краснодарского края / О. В. Зеленская // Рисоводство. - Краснодар, 2020. - № 1 (46). - С. 78-84.

9. Зеленская, О. В. Новые сорные растения рода Ammannia L. на рисовых полях Краснодарского края / О. B. Зеленская, С. А. Москвитин, Н. В. Швыдкая // Рисоводство. - Краснодар, 2018. - №4 (41). - С. 33-37.

10. Зеленский, Г. Л. Совершенствование технологии возделывания риса в санитарных зонах (на примере учхоза «Кубань») / Г. Л. Зеленский, М. И. Чеботарев, Т. В. Логойда, О. В. Зеленская, А. А. Салай // Труды КубГАУ. - Краснодар, 2018. - № 5 (74). - С. 53-57.

11. Косенко, И. С. Проблема борьбы с сорняками в условиях рисового хозяйства СССР: дисс. .... д-ра с.-х. наук / И. С. Косенко; КубСХИ. - Краснодар, 1940. - 372 с.

12. Костылев, П. И. Сорные растения, болезни и вредители рисовых агроценозов юга России: справ. и учеб.-метод. пособие / П. И. Костылев, К. С. Артохин. - М.: Печатный Город, 2010. - 368 с.

13. Кулагин, О. В. Устойчивость однолетних мятликовых сорняков к гербицидам / О. В. Кулагин // Защита и карантин растений. - Москва, 2012. - № 11. - С. 12-15.

14. Лукачева, Н. Г. Резистентность ежовников в посевах риса в условиях Дальнего Востока / Н. Г. Лукачева, А. В. Костюк // Фитосанитарная безопасность агроэкосистем: Материалы Междунар. науч. конф. - Новосибирск, 2010. - C. 152-155.

15. Лукачева, Н. Г. Формирование резистентности к гербициду Сегмент в популяциях ежовников Echinochloa / H. Г. Лукачева, А. В. Костюк // Вестник ДВО РАH. - 2019. - № 3. - С. 97-102. DOI: 10.25808/08697698.2019.205.3.017

16. Система рисоводства Краснодарского края: Рекомендации / под общ. ред. Е. М. Харитонова. - Краснодар, 2005. $-340 \mathrm{c}$.

17. Ульянова, Т. Н. Сорные растения как особая экологическая группа дикорастущих видов / Т. Н. Ульянова // Мобилизация, изучение и использование генетических ресурсов растений: сб. науч. тр. - Л.: ВИР, 1991. - Т. 140. C. 131-136.

18. Устойчивость сорных растений к гербицидам // Наше сельское хозяйство. - 2019. - № 11. - С. 92-99.

19. Устойчивость сорных растений к гербицидам. Продолжение // Наше сельское хозяйство. - 2019. - № 13. - С. 52-58.

20. Bajwa, A. A. Eco-biology and management of Echinochloa crus-galli / A. A. Bajwa, K. Jabran, M. Shahid, H. H. Ali, B. Chauhan, S. Ehsanullah // Crop Prot. - 2015. - vol. 75. - P. 151-162.

21. Chayapakdee, P. Quinclorac resistance in Echinochloa phyllopogon is associated with reduced ethylene synthesis rather than enhanced cyanide detoxification by $\beta \square$ cyanoalanine synthase / P. Chayapakdee, Y. Sunohara, M. Endo, T. Yamaguchi, L. Fan, A. Uchino, H. Matsumoto, S. Iwakami // Pest Management Science. - 2020. - 76 (4). - P. 1195-1204. https://doi.org/10.1002/ps.5660

22. Chen, G. Q. Penoxsulam-resistant barnyardgrass (Echinochloa crus-galli) in rice fields in China / G. Q. Chen, Q. Wang, Z. W. Yao, L. F. Zhu, L. Y. Dong // Weed Biol. Manag. - 2016. - 16 (1). - P. 16-23.

23. Chen, L. J. Gene flow from cultivated rice (Oryza sativa) to its weedy and wild relatives / L. J. Chen, B.-R. Lu // Annals of Botany. - 2004. - 93. - P. 67-73.

24. Fang, J. Target Site-Based Penoxsulam Resistance in Barnyardgrass (Echinochloa crus-galli) from China / J. Fang, T. Liu, Y. Zhang, J. Li, L. Dong // Weed Science. - 2019. - 67(3). - P. 281-287. https://doi.org/10.1017/wsc.2019.5

25. Fischer, A. J. Mechanisms of resistance to bispyribac-sodium in an Echinochloa phyllopogon accession / A. J. Fischer, D. E. Bayer, M. D. Carriere, C. M. Ateh, K.-O. Yim // Pestic. Biochem. Physiol. - 2000. - 68. - P. $156-165$.

26. Jia, W. Q. Distribution and genetic diversity of Echinochloa oryzicola resistant to ALS and ACCase inhibitors in Korea / W. Q. Jia, O. J. Won, B. Khaitov, J. Lee, K. W. Park // International Journal of Pest Management. - 2020. 10.1080/09670874.2020.1730479, (1-10).

27. Juliano, L. M. Multiple herbicide resistance in barnyardgrass (Echinochloa crus-galli) in direct seeded rice in the Philippines / L. M. Juliano, M. C. Casimero, R. Lewellyn // International Journal of Pest Management. - 2010. - vol. 56, is. 4. - P. 299-307.

28. Kaloumenos, N. S. Target-site mutation associated with cross-resistance to ALS-inhibiting herbicides in late water- 
grass (Echinochloa oryzicola Vasing) / N. S. Kaloumenos, S. L. Chatzilazaridou, P. V. Mylona, A. N. Polidoros, I. G. Eleftherohorinos // Pest Management Science. - 2013. - vol. 69. - P. 865-873.

29. Liu, J. Target Site-Based Resistance to Penoxsulam in Late Watergrass (Echinochloa phyllopogon) from China / J. Liu, J. Fang, Z. He, G. Li, L. Dong // Weed Science. - 2019. - 67 (4). - P. 380-388. https://doi.org/10.1017/wsc.2019.14

30. Liu, X. Herbicide Resistance in China: A Quantitative Review / X. Liu, S. Xiang, T. Zong, G. Ma, L. Wu, K. Liu, X. Zhou, L. Bai // Weed Science . - 2019. - 67 (6). - P. 605-612. https://doi.org/10.1017/wsc.2019.46

31. Lu, B. R. Gene flow from genetically modified rice to its wild relatives: Assessing potential ecological consequences / B. R. Lu, C. Yang // Biotechnol. Adv. - 2009. - 27 (6). - P. 1083-1091.

32. Malik, M. S. Confirmation and control of propanilresistant Barnyard grass (Echinochloa crus-galli) in rice / M. S. Malik, N. R. Burgos, R. E. Talbert // Weed Technology. - 2010. - Vol. 24, is. 3. - P. 226-233.

33. Marchesi, C. First Report of Herbicide-Resistant Echinochloa crus-galli in Uruguayan Rice Fields / C. Marchesi, N. E. Saldain // Agronomy. - 2019. - 9 (12) . - P. 790. https://doi.org/10.3390/agronomy9120790

34. Matzenbacher, F. Distribution and analysis of the mechanisms of resistance of barnyardgrass (Echinochloa crus-galli) to imidazolinone and quinclorac herbicides / F. Matzenbacher, E. Bortoly, A. Kalsing, A. Merotto // The Journal of Agricultural Science. - 2015. - 153(6) . - P. 1044-1058. DOI: https://doi.org/10.1017/S0021859614000768

35. Norsworthy, J. K. ALS-resistant barnyardgrass / J. K. Norsworthy, M. J. Wilson, R. C. Scott, E. E. Gbur // Weed Biol Manag. - 2014. - 14. - P. 50-58.

36. Osuna, M. D. Genetic Diversity and Spread of Thiobencarb Resistant Early Watergrass (Echinochloa oryzoides (Ard.) Fritsch) in California / M. D. Osuna, M. Okada, R. Ahmad, A. J. Fischer, M. Jasieniuk // Weed Science. - 2011. - vol. 59, is. 2. - P. 195-201. https://doi.org/10.1614/WS-D-10-00124.1

37. Pedroso, R. M. ALS Inhibitor-Resistant Smallflower Umbrella Sedge (Cyperus difformis) Seed Germination Requires Fewer Growing Degree Days and Lower Soil Moisture / R. M. Pedroso, C. van Kessel, D. D. Neto, B. A. Linquist, L. G. Boddy, K. Al-Khatib, A. J. Fisher // Weed Science. - 2019. - 68(1). - P. 51-62. https://doi.org/10.1017/wsc.2019.57

38. Qiong, P. Quinclorac Resistance in Echinochloa crus-galli from China / P. Qiong, H. Heping, Y. Xia, B. Lianyang, Y. Qin, S. B. Powles // Rice Science. - 2019. - 26 (5). - P. 300-308. https://doi.org/10.1016/j.rsci.2019.08.004

39. Rahman, M. M. Study on resistant biotypes of Echinochloa crus-galli in Malaysia / M. M. Rahman, I. B. Sahid, A. S. Juraimi // Australian Journal of Crop Science. - 2010. - vol. 4, № 2. - P. 107-115.

40. Rutledge, J. RAPD analysis of genetic variation among propanil-resistant and susceptible Echinochloa crus-galli populations in Arkansas / J. Rutledge, R. E. Talbert, C. H. Sneller // Weed Science. - 2000. - 48. - P. 669-674.

41. Sanders, T. L. Evaluation of weed control in acetyl coA carboxylase-resistant rice with mixtures of quizalofop and auxinic herbicides / T. L. Sanders, J. A. Bond, B. H. Lawrence, B. R. Golden, T. W. Allen Jr, T. Bararpour // Weed Technology. - 2019. - 34 (4). - P. 498-505. https://doi.org/10.1017/wet.2019.134

42. von Schirnding, Y. E. Health-and-environment indicators in the context of sustainable development / Y. E. von Schirnding // Can J Public Health. - 2002. - 93, Suppl 1. - P. 9-15.

43. Shen, C. Isoxadifen-Ethyl Derivatives Protect Rice from Fenoxaprop-P-Ethyl-associated Injury during the Control of Weedy Rice / C. Shen, W. Tang, D. Zeng, H. Xu, W. Su, R. Wu // Weed Science. - 2017. - 65(5). - P. 579-587. https://doi. org/10.1017/wsc.2017.27

44. Shivrain, V. R. Maximum outcrossing rate and genetic compatibility between red rice (Oryza sativa) biotypes and Clearfield $^{\mathrm{TM}}$ rice / V. R. Shivrain, N. R. Burgos, D. R. Gealy, K. A. K. Moldenhauer, C. J. Baquireza // Weed Science. - 2008. - Vol. 56, is. 6. - P. 807-813.

45. Song, J.-S. Cross-resistance of Echinochloa species to acetolactate synthase inhibitor herbicides / J. -S. Song, S.-H. Lim, M.-J. Yook, J.-W. Kim, D.-S. Kim // Weed Biology and Management. - 2017. - 17 (2). - P. 91-102.

46. Tehranchian, P. ALS-Resistant Smallflower Umbrella Sedge (Cyperus difformis) in Arkansas Rice: Physiological and Molecular Basis of Resistance / P. Tehranchian, D. Riar, J. Norsworthy, V. Nandula, S. McElroy, S. Chen, R. Scott // Weed Science. - 2015. - 63(3). - P. 561-568. doi:10.1614/WS-D-14-00147.1

47. UI Haq, M. Z. Ethylene Biosynthesis Inhibition Combined with Cyanide Degradation Confer Resistance to Quinclorac in Echinochloa crus-galli var. mitis / M. Z. Ul Haq, Z. Zhang, J. Wei, S. Qiang // Int. J. Mol. Sci. - 2020. - 21(5). 1573. https://doi.org/10.3390/ijms21051573

48. Vignola, M. D. Limited induction of ethylene and cyanide synthesis are observed in quinclorac-resistant barnyardgrass (Echinochloa crus-galli) in Uruguay / M. D. Vignola, M. Sainz, N. E. Saldain, C. Marchesi, V. Bonnecarrère, P. D. Gadea // Weed Science. - 2020. - vol. 68, is. 4. - P. 348-357. DOI: https://doi.org/10.1017/wsc.2020.32

49. Webster, E. P. Quizalofop-p-ethyl mixed with synthetic auxin and ACCase-inhibiting herbicides for weed management in rice production / E. P. Webster, S. Y. Rustom Jr, B. M. McKnight, D. C. Blouin, G. M. Telo // Int. J. Agron. - 2019. doi:10.1155/2019/6137318

50. Weedy rices - origin biology, ecology and control / J. C. Delouche, N. R. Burgos, D. R. Gealy et al. // FAO plant production and protection paper. - Roma, 2007. - 188. - $150 \mathrm{p}$.

\section{REFERENCES}

1. Artokhin, K.S. Weedy plants / K.S. Artokhin. - Rostov-on-Don, 2004 . - 144 p.

2. Rice weed control / under editorship of V. D. Agarkov et al. - Moscow: Kolos, 1972 . - 149 p.

3. Bragina, O. A. Weeds resistance to herbicides / O. A. Bragina // Rice growing. - Krasnodar, 2016. - № 1-2 (30-31). - P. 46-49.

4. Gulidov, A. M. On the aftereffect of herbicides / A. M. Gulidov // Plant protection and quarantine. - 2003. - № 2. - P. 25-26. 
5. Zelenskaya, O. V. Analysis of the segetal flora of rice fields in the Kuban river delta / O. V. Zelenskaya // Proceedings of the KubSAU. - Krasnodar, 2010. № 1 (22). - P.81-85.

6. Zelenskaya, O.V. On the issue of cultivating rice varieties resistant to herbicides / O.V. Zelenskaya // Polythematic network electronic scientific journal of the Kuban State Agrarian University (Scientific journal of KubSAU) [Electronic resource]. - Krasnodar, 2011. - № 03 (67). - Access mode: http: ej.kubagro. ru / 2011/03 / pdf / 11.pdf.

7. Zelenskaya, O. V. Dynamics of the number of weeds of the Poaceae family in the rice fields of the Kuban / O.V. Zelenskaya // Rice growing. - Krasnodar, 2019. - № 1 (42). - P. 37-42.

8. Zelenskaya, O. V. Weed plants of the genus Lindernia All. in the rice fields of Krasnodar region / O. V. Zelenskaya // Rice growing. - Krasnodar, 2020. - № 1 (46). - P. 78-84.

9. Zelenskaya, O. V. New weeds of the genus Ammannia L. in the rice fields of Krasnodar region / O. V. Zelenskaya, S. A. Moskvitin, N. V. Shvydkaya // Rice growing. - Krasnodar, 2018. - № 4 (41). - P. 33-37.

10. Zelensky, G. L. Improving the technology of rice cultivation in sanitary zones (on the example of the Kuban educational farm) / G. L. Zelensky, M. I. Chebotarev, T. V. Logoida, O. V. Zelenskaya, A. A. Salai // Proceedings of KubSAU. - Krasnodar, 2018. - № 5 (74). - P. 53-57.

11. Kosenko, I. S. The problem of weed control in the conditions of the rice farming of the USSR: Dr. thesis / I. S. Kosenko; Kuban Agricultural Institute. - Krasnodar, 1940 . - 372 p.

12. Kostylev, P.I. Weed plants, diseases and pests of rice agrocenoses in the south of Russia: scientific and reference textbook/ P.I. Kostylev, K.S. Artokhin. - M .: Pechatny Gorod, 2010 . - 368 p

13. Kulagin, O.V. Resistance of annual bluegrass weeds to herbicides / O.V. Kulagin // Plant protection and quarantine. - Moscow, 2012. - № 11. - P. 12-15.

14. Lukacheva, N. G. Resistance of barnacles in rice crops in the Far East / N. G. Lukacheva, A. V. Kostyuk // Phytosanitary safety of agroecosystems: Proceedings of the Intern. scientific. conf. - Novosibirsk, 2010 . - P. 152-155.

15. Lukacheva, N. G. Formation of resistance to Segment herbicide in populations of Echinochloa barnacles / N. G. Lukacheva, A. V. Kostyuk // Bulletin of the Far East Branch of the Russian Academy of Sciences. - 2019. - № 3. - P. 97-102. DOI: 10.25808 / 08697698.2019.205.3.017

16. Rice growing system of Krasnodar region: Recommendations / under editorship of E. M. Kharitonov. - Krasnodar, 2005 . -340 p.

17. Ulyanova, T.N. Weed plants as a special ecological group of wild-growing species / T.N. Ulyanova // Mobilization, study and use of plant genetic resources: collection of articles - L .: VIR, 1991. - V. 140. - P. 131-136.

18. The resistance of weeds to herbicides // Our agriculture. - 2019. - № 11. - P. 92-99.

19. Weed resistance to herbicides. Continuation // Our agriculture. - 2019. - № 13. - P. 52-58.

20. Bajwa, A. A. Eco-biology and management of Echinochloa crus-galli / A. A. Bajwa, K. Jabran, M. Shahid, H. H. Ali, B. Chauhan, S. Ehsanullah // Crop Prot. - 2015. - vol. 75. - P. 151-162.

21. Chayapakdee, P. Quinclorac resistance in Echinochloa phyllopogon is associated with reduced ethylene synthesis rather than enhanced cyanide detoxification by $\beta$-cyanoalanine synthase / P. Chayapakdee, Y. Sunohara, M. Endo, T. Yamaguchi, L. Fan, A. Uchino, H. Matsumoto, S. Iwakami // Pest Management Science. - 2020. - 76 (4). - P. 1195-1204. https://doi.org/10.1002/ps.5660

22. Chen, G. Q. Penoxsulam-resistant barnyardgrass (Echinochloa crus-galli) in rice fields in China / G. Q. Chen, Q. Wang, Z. W. Yao, L. F. Zhu, L. Y. Dong // Weed Biol. Manag. - 2016. - 16 (1). - P. 16-23.

23. Chen, L. J. Gene flow from cultivated rice (Oryza sativa) to its weedy and wild relatives / L. J. Chen, B.-R. Lu // Annals of Botany. - 2004. - 93. - P. 67-73.

24. Fang, J. Target Site-Based Penoxsulam Resistance in Barnyardgrass (Echinochloa crus-galli) from China / J. Fang, T. Liu, Y. Zhang, J. Li, L. Dong // Weed Science. - 2019. - 67(3). - P. 281-287. https://doi.org/10.1017/wsc.2019.5

25. Fischer, A. J. Mechanisms of resistance to bispyribac-sodium in an Echinochloa phyllopogon accession / A. J. Fischer, D. E. Bayer, M. D. Carriere, C. M. Ateh, K.-O. Yim // Pestic. Biochem. Physiol. - 2000. - 68. - P. $156-165$.

26. Jia, W. Q. Distribution and genetic diversity of Echinochloa oryzicola resistant to ALS and ACCase inhibitors in Korea / W. Q. Jia, O. J. Won, B. Khaitov, J. Lee, K. W. Park // International Journal of Pest Management. - 2020. 10.1080/09670874.2020.1730479, (1-10).

27. Juliano, L. M. Multiple herbicide resistance in barnyardgrass (Echinochloa crus-galli) in direct seeded rice in the Philippines / L. M. Juliano, M. C. Casimero, R. Lewellyn // International Journal of Pest Management. - 2010. - vol. 56, is. 4. - P. 299-307.

28. Kaloumenos, N. S. Target-site mutation associated with cross-resistance to ALS-inhibiting herbicides in late watergrass (Echinochloa oryzicola Vasing) / N. S. Kaloumenos, S. L. Chatzilazaridou, P. V. Mylona, A. N. Polidoros, I. G. Eleftherohorinos // Pest Management Science. - 2013. - vol. 69. - P. 865-873.

29. Liu, J. Target Site-Based Resistance to Penoxsulam in Late Watergrass (Echinochloa phyllopogon) from China / J. Liu, J. Fang, Z. He, G. Li, L. Dong // Weed Science. - 2019. - 67 (4). - P. 380-388. https://doi.org/10.1017/wsc.2019.14

30. Liu, X. Herbicide Resistance in China: A Quantitative Review / X. Liu, S. Xiang, T. Zong, G. Ma, L. Wu, K. Liu, X. Zhou, L. Bai // Weed Science . - 2019. - 67 (6). - P. 605-612. https://doi.org/10.1017/wsc.2019.46

31. Lu, B. R. Gene flow from genetically modified rice to its wild relatives: Assessing potential ecological consequences / B. R. Lu, C. Yang // Biotechnol. Adv. - 2009. - 27 (6). - P. 1083-1091.

32. Malik, M. S. Confirmation and control of propanilresistant Barnyard grass (Echinochloa crus-galli) in rice / M. S. Malik, N. R. Burgos, R. E. Talbert // Weed Technology. - 2010. - Vol. 24, is. 3. - P. 226-233. 
33. Marchesi, C. First Report of Herbicide-Resistant Echinochloa crus-galli in Uruguayan Rice Fields / C. Marchesi, N. E. Saldain // Agronomy. - 2019. - 9 (12) . - P. 790. https://doi.org/10.3390/agronomy9120790

34. Matzenbacher, F. Distribution and analysis of the mechanisms of resistance of barnyardgrass (Echinochloa crus-galli) to imidazolinone and quinclorac herbicides / F. Matzenbacher, E. Bortoly, A. Kalsing, A. Merotto // The Journal of Agricultural Science. - 2015. - 153(6) . - P. 1044-1058. DOI: https://doi.org/10.1017/S0021859614000768

35. Norsworthy, J. K. ALS-resistant barnyardgrass / J. K. Norsworthy, M. J. Wilson, R. C. Scott, E. E. Gbur // Weed Biol Manag. - 2014. - 14. - P. 50-58.

36. Osuna, M. D. Genetic Diversity and Spread of Thiobencarb Resistant Early Watergrass (Echinochloa oryzoides (Ard.) Fritsch) in California / M. D. Osuna, M. Okada, R. Ahmad, A. J. Fischer, M. Jasieniuk // Weed Science. - 2011. - vol. 59, is. 2. - P. 195-201. https://doi.org/10.1614/WS-D-10-00124.1

37. Pedroso, R. M. ALS Inhibitor-Resistant Smallflower Umbrella Sedge (Cyperus difformis) Seed Germination Requires Fewer Growing Degree Days and Lower Soil Moisture / R. M. Pedroso, C. van Kessel, D. D. Neto, B. A. Linquist, L. G. Boddy, K. Al-Khatib, A. J. Fisher // Weed Science. - 2019. - 68(1). - P. 51-62. https://doi.org/10.1017/wsc.2019.57

38. Qiong, P. Quinclorac Resistance in Echinochloa crus-galli from China / P. Qiong, H. Heping, Y. Xia, B. Lianyang, Y. Qin, S. B. Powles // Rice Science. - 2019. - 26 (5). - P. 300-308. https://doi.org/10.1016/j.rsci.2019.08.004

39. Rahman, M. M. Study on resistant biotypes of Echinochloa crus-galli in Malaysia / M. M. Rahman, I. B. Sahid, A. S. Juraimi // Australian Journal of Crop Science. - 2010. - vol. 4. - № 2. - P. 107-115.

40. Rutledge, J. RAPD analysis of genetic variation among propanil-resistant and susceptible Echinochloa crus-galli populations in Arkansas / J. Rutledge, R. E. Talbert, C. H. Sneller // Weed Science. - 2000. - 48. - P. 669-674.

41. Sanders, T. L. Evaluation of weed control in acetyl coA carboxylase-resistant rice with mixtures of quizalofop and auxinic herbicides / T. L. Sanders, J. A. Bond, B. H. Lawrence, B. R. Golden, T. W. Allen Jr, T. Bararpour // Weed Technology. - 2019. - 34 (4). - P. 498-505. https://doi.org/10.1017/wet.2019.134

42. von Schirnding, Y. E. Health-and-environment indicators in the context of sustainable development / Y. E. von Schirnding // Can J Public Health. - 2002. - 93, Suppl 1. - P. 9-15.

43. Shen, C. Isoxadifen-Ethyl Derivatives Protect Rice from Fenoxaprop-P-Ethyl-associated Injury during the Control of Weedy Rice / C. Shen, W. Tang, D. Zeng, H. Xu, W. Su, R. Wu // Weed Science. - 2017. - 65(5). - P. 579-587. https://doi. org/10.1017/wsc.2017.27

44. Shivrain, V. R. Maximum outcrossing rate and genetic compatibility between red rice (Oryza sativa) biotypes and Clearfield ${ }^{\mathrm{TM}}$ rice / V. R. Shivrain, N. R. Burgos, D. R. Gealy, K. A. K. Moldenhauer, C. J. Baquireza // Weed Science. - 2008. - Vol. 56. - is. 6. - P. 807-813.

45. Song, J.-S. Cross-resistance of Echinochloa species to acetolactate synthase inhibitor herbicides / J.-S. Song, S.-H. Lim, M.-J. Yook, J.-W. Kim, D.-S. Kim // Weed Biology and Management. - 2017. - 17 (2). - P. 91-102.

46. Tehranchian, P. ALS-Resistant Smallflower Umbrella Sedge (Cyperus difformis) in Arkansas Rice: Physiological and Molecular Basis of Resistance / P. Tehranchian, D. Riar, J. Norsworthy, V. Nandula, S. McElroy, S. Chen, R. Scott // Weed Science. - 2015. - 63(3). - P. 561-568. doi:10.1614/WS-D-14-00147.1

47. UI Haq, M. Z. Ethylene Biosynthesis Inhibition Combined with Cyanide Degradation Confer Resistance to Quinclorac in Echinochloa crus-galli var. mitis / M. Z. UI Haq, Z. Zhang, J. Wei, S. Qiang // Int. J. Mol. Sci. - 2020. - 21(5). 1573. https://doi.org/10.3390/ijms21051573

48. Vignola, M. D. Limited induction of ethylene and cyanide synthesis are observed in quinclorac-resistant barnyardgrass (Echinochloa crus-galli) in Uruguay / M. D. Vignola, M. Sainz, N. E. Saldain, C. Marchesi, V. Bonnecarrère, P. D. Gadea // Weed Science. - 2020. - Vol. 68. - is. 4. - P. 348-357. DOI: https://doi.org/10.1017/wsc.2020.32

49. Webster, E. P. Quizalofop-p-ethyl mixed with synthetic auxin and ACCase-inhibiting herbicides for weed management in rice production / E. P. Webster, S. Y. Rustom Jr, B. M. McKnight, D. C. Blouin, G. M. Telo // Int. J. Agron. - 2019. doi:10.1155/2019/6137318

50. Weedy rices - origin biology, ecology and control / J. C. Delouche, N. R. Burgos, D. R. Gealy et al. // FAO plant production and protection paper. - Roma, 2007. - 188. - 150 p.

\section{Зеленская Ольга Всеволодовна}

Доцент кафедры ботаники и общей экологии

E-mail: zelenskayaolga-2011@mail.ru

ФГБОУ ВО «Кубанский государственный аграрный университет им. И.Т. Трубилина»

350044, г. Краснодар, ул. Калинина, 13

\section{Zelenskaya Olga Vsevolodovna}

Associate Professor at the Department of Botany

and General Ecology

E-mail: zelenskayaolga-2011@mail.ru

FSBEI HE "Kuban State Agrarian University named after I.T. Trubilin"

13, Kalinina, Krasnodar, 350044, Russia 
С.В. Гаркуша, д-р с.-х. наук, профессор, С.А. Тешева, канд. биол. наук г. Краснодар, Россия

\section{ОЦЕНКА ЭКОНОМИЧЕСКОЙ ЭФФЕКТИВНОСТИ ВЫРАЩИВАНИЯ КУКУРУЗЫ В КРАСНОДАРСКОМ КРАЕ}

В статье представлены результаты оценки эффективности производства кукурузы в Краснодарском крае. Использовались материалы статистических сборников Федеральной службы государственной статистики, Федеральной службы государственной статистики по Краснодарскому краю и Республике Адыгея, литературные источники. На долю Южного федерального округа приходится порядка 30 \% от посевной площади кукурузы в Российской Федерации. Основным регионом выращивания кукурузы является Краснодарский край, доля которого составляет более 80 \% в общей структуре посевов. Валовой сбор кукурузы в последние 5 лет увеличился. В 2019 году составил 2532, 7 тонн в весе после доработки при средней урожайности 49,7 ц/га. Повышение эффективности производства кукурузы в Краснодарском крае стало возможным не только за счет увеличения посевных площадей, но и за счет совершенствования технологии возделывания культуры и использования новых высокопродуктивных гибридов кубанской селекции. Приведена структура затрат на производство кукурузы. Наряду с увеличением продуктивности кукурузы и интенсификации производства изменились и экономические показатели производства культуры: наблюдается увеличение по всем статьям затрат, что отразилось на росте общих затрат на один гектар. За последние 5 лет они увеличились на 1770,6 рубля. Себестоимость одной тонны кукурузы за период 2015-2019 гг. увеличилась на 2947,2 рубля. В целях дальнейшего развития обсуждается вопрос о необходимости снижения себестоимости продукции, оптимизации структуры затрат на производство культуры. Анализ опыта выращивания кукурузы в Краснодарском крае показывает, что потенциальные возможности позволяют увеличить объем производства, повысить рентабельность, создать условия для обеспечения населения, безопасной сельскохозяйственной продукцией путем совершенствования технологии возделывания кукурузы, использования новых высокопродуктивных гибридов кубанской селекции, применения новых средств защиты растений и минеральных удобрений.

Ключевые слова. кукуруза, гибрид, урожайность, структура затрат, себестоимость, рентабельность.

\section{EVALUATION OF EFFICIENCY OF CORN GROWING IN KRASNODAR REGION}

The article presents the results of assessing the efficiency of corn production in the Krasnodar region. Research methods included economic and statistical. The materials of statistical collections of the Office of the federal Service state statistics, Federal State Statistics Service for Krasnodar region and the Republic of Adygea and literary sources were used. The Southern Federal District accounts for about $30 \%$ of the sown area in the Russian Federation. The main region for growing corn is Krasnodar region, which accounts for more than $80 \%$ of the total crop structure. The gross harvest of soybeans in the last 5 years has increased. In 2019, it amounted to 2532.7 tons in weight after revision with an average yield of $49.7 \mathrm{c} / \mathrm{ha}$. Improving the efficiency of corn production in Krasnodar region has become possible not only by increasing the acreage, but also by improving the technology of cultivation and the use of new highly productive hybrids of Kuban breeding. The costs structure for corn production is given. Along with the increase in the corn productivity and the intensification of production, the economic indicators of crop production also changed: an increase in all cost items, which was reflected in an increase in total costs per hectare. Over the past 5 years, they have increased by 1770.6 rubles. Cost of one ton of corn for the period 2015-2019 increased by 2947.2 rubles. In order to further develop the community, the issue of the need to reduce the cost of production, optimize the costs structure for crop production is being discussed. An analysis of the experience of growing corn in Krasnodar region shows that potential opportunities allow increasing the volume of corn production, increasing profitability, creating conditions for providing the population with safe agricultural products by improving the technology of corn cultivation, using new highly productive hybrids of Kuban breeding, using new plant protection products and mineral fertilizers.

Key words. corn, hybrid, yield, costs structure, prime cost, profitability. 


\section{Введение}

Кукуруза (Zea mays) - одна из ведущих зерновых культур мирового земледелия. Кукуруза на зерно возделывается в мире на площади более 140 млн. га [9]. Широкому распространению и увеличению производства кукурузы способствует высокая урожайность и широкие возможности использования как продукта питания, так и ценного корма для сельскохозяйственных животных [6, 9]. Кукуруза в Российской Федерации является одной из важнейших зерновых культур и имеет высокую экономическую, экологическую и социальную значимость в аграрном секторе [6, 10].

По данным Федеральной службы государственной статистики в Российской Федерации в последние годы кукурузу на зерно выращивают на площади 2,5-
3,0 млн. га, валовой сбор составляет 13,1-15,2 млн. тонн, урожайность 4,9-5,7 т/га (табл. 1) [7, 8].

В период 2015-2019 гг. посевные площади в Российской Федерации увеличились на 524,7 тыс. га, достигнув рекордного показателя в 2017 году 3019,1 тыс. га (табл. 1) [7, 8]. Посевные площади кукурузы в России в 2019 году, по данным Федеральной службы государственной статистики (Росстат) в хозяйствах всех категорий составили 2 585,9 тыс. га, что на 3,7 \% (на 91,5 тыс. га) больше, чем в 2018 году [9]. В период с 2015 по 2019 годы валовой сбор увеличился на 6 \%. Средняя урожайность кукурузы в России в 2019 году составила 57,5 ц/га (в весе после доработки), что на 19,5 \% (на 9,4 ц/га) больше, чем 2018 году. За 5 лет показатель урожайности кукурузы увеличился на $16,6 \%$ (на 8,2 ц/га).

\section{Таблица 1. Производство зерна кукурузы в Российской Федерации (по данным Росстата)}

\begin{tabular}{|l|c|c|c|c|c|}
\hline Показатели & $\mathbf{2 0 1 5}$ г. & $\mathbf{2 0 1 6}$ г. & $\mathbf{2 0 1 7}$ г. & $\mathbf{2 0 1 8}$ г. & $\mathbf{2 0 1 9}$ г. \\
\hline Площадь, тыс. га: & 2761,5 & 2887,4 & 3019,1 & 2494,4 & 2585,9 \\
\hline Валовой сбор, тыс. тонн: & 13137,6 & 15281,6 & 13208,1 & 11419,0 & 13928,7 \\
\hline Урожайность, ц/га: & 49,3 & 55,1 & 49,0 & 48,1 & 57,5 \\
\hline
\end{tabular}

В настоящее время выращиванием кукурузы занимаются в 10 субъектах Российской Федерации, на них приходится около 80 \% всего валового сбора зерна этой культуры. Многолетний накопленный научный опыт и передовая практика свидетельствуют о реальной возможности эффективного возделывания этой ценной культуры в широком ареале [9, 10]. Это подтверждают результаты работы отечественных селекционных программ и показатели производства сельскохозяйственных товаропроизводителей аграрных регионов страны. Основными регионами выращивания кукурузы на зерно являются Краснодарский край, Воронежская, Белгородская, Курская и Ростовская области, Северокавказские республики и Ставропольский край.

Одним из регионов Российской Федерации, обладающим большим потенциалом для выращивания кукурузы, является Южный федеральный округ, на долю которого приходится 30 \% от посевной площади в Российской Федерации. Основным регионом выращивания кукурузы является Краснодарский край, доля которого составляет более 80 \% в общей структуре посевов округа [9].

Данный факт подтверждает высокую экономическую целесообразность выращивания этой культуры, а также стабильный внутренний интерес и высокий потенциал импортозамещения.

\section{Цель исследований}

Оценить экономическую эффективность выращивания кукурузы в Краснодарском крае.

\section{Материалы и методы}

Исходными данными послужили материалы статистических сборников Федеральной службы го- сударственной статистики (Росстат), Управления Федеральной службы государственной статистики по Краснодарскому краю и Республике Адыгея.

\section{Результаты и обсуждение}

В Краснодарском крае кукуруза возделывается в 43 муниципальных образованиях. Наибольшие площади сосредоточены в Новопокровском, Отрадненском, Кущевском, Гулькевичском, Новокубанском районах $(5,7 \%, 5,0 \%, 4,3$ \%, 3,8 \% и 3,8 \% соответственно).

В период реформ в России производство кукурузы в Краснодарском крае было убыточным. За период 1990-2000 гг. посевные площади были снижены до 206,2 тыс. га и урожайность до 26,5 ц/га, что привело к формированию объема производства зерна кукурузы до 533,1 тыс. тонн. С 2001 года динамика объемов производства кукурузы в Краснодарском крае устойчиво положительная. В 2015 году в хозяйствах всех форм собственности посевы кукурузы на зерно занимали площадь 613,0 тыс. га и 81,9 тыс. га кукуруза на корм. За последние 5 лет объем производства кукурузы ежегодно составляет порядка 2,5-3,0 тыс. тонн а средняя урожайность за 5 лет - 48,5 ц/га. В 2019 году собрано 2532,7 тыс. тонн зерна в зачетном весе [2, 3, 4, 5] при урожайности 49,7 ц/га. Исключение для отрасли составили 2017 и 2018 годы, когда показатели производства были снижены в связи с уменьшением посевных площадей и влиянием неблагоприятных погодных условий в период интенсивного роста и развития кукурузы, которые существенно повлияли на формирования урожая (табл. 2). 
Таблица 2. Показатели производства кукурузы в Краснодарском крае (по данным Управления Федеральной службы государственной статистики по Краснодарскому краю и Республике Адыгея)

\begin{tabular}{|l|c|c|c|}
\hline \multirow{2}{*}{\multicolumn{2}{|c|}{ Год }} & \multicolumn{2}{c|}{ Показатели } \\
\cline { 2 - 4 } & Площадь, тыс. га & Валовый сбор, тыс. тонн & Урожайность, ц/га \\
\hline $1990-2000$ (средн.) & 206,2 & 497,1 & 28,9 \\
\hline $2001-2011$ (средн.) & 406,7 & 1345,0 & 46,2 \\
\hline 2012 & 656,7 & 2752,7 & 53,5 \\
\hline 2013 & 620,7 & 3292,7 & 53,6 \\
\hline 2014 & 622,1 & 3309,8 & 53,7 \\
\hline 2015 & 613,0 & 3291,8 & 55,1 \\
\hline 2016 & 641,0 & 3531,9 & 50,5 \\
\hline 2017 & 678,0 & 3420,0 & 33,5 \\
\hline 2018 & 569,0 & 1907,0 & 49,7 \\
\hline 2019 & 509,6 & 2532,7 & \\
\hline
\end{tabular}

Средняя урожайность культуры в последние пять лет в некоторых районах края перешагнула рубеж 70 ц/га, что свидетельствует не только о высоком потенциале культуры, но и об имеющейся возможности наращивания объемов производства.

Повышение эффективности производства кукурузы в Краснодарском крае стало возможным за счет совершенствования технологии возделывания кукурузы и использования новых высокопродуктивных гибридов кубанской селекции, высокотехнологичных и энергоемких машин и орудий для выращивания и уборки кукурузы; рационального использования имеющихся производственных ресурсов, интен- сификации производства. Дальнейшее развитие связано с оптимизацией структуры посевных площадей в системе севооборота, повышением культуры земледелия и научным обеспечением отрасли, баланса между затратами на производство и урожайностью культуры. Для установления характера влияния урожайности на показатели экономической эффективности производства кукурузы был проведён анализ статистических материалов [2, 3, 4, 5].

Наряду с увеличением продуктивности кукурузы и интенсификацией производства изменились и экономические показатели производства культуры (табл. 3).

Таблица 3. Эффективность производства кукурузы в Краснодарском крае

\begin{tabular}{|l|c|c|c|c|c|}
\hline \multicolumn{1}{|c|}{ Статьи затрат, руб. } & $\mathbf{2 0 1 5}$ & $\mathbf{2 0 1 6}$ & $\mathbf{2 0 1 7}$ & $\mathbf{2 0 1 8}$ & $\mathbf{2 0 1 9}$ \\
\hline Общие затраты на 1 га & 10130,0 & 10836,6 & 11900,6 & 9592,0 & 11514,0 \\
\hline Полная себестоимость 1 т. & 5583,3 & 6215,1 & 6857,9 & 8729,8 & 8530,5 \\
\hline $\begin{array}{l}\text { Производственная } \\
\text { себестоимость 1 т. }\end{array}$ & 5383,3 & 5979,1 & 6936,3 & 10415,4 & 7588,1 \\
\hline Цена реализации 1 т. & 8668,8 & 9313,8 & 8396,4 & 9872,8 & 10255,0 \\
\hline Прибыль, руб./т. & 3085,5 & 3098,7 & 1538,5 & 1143,0 & 1724,5 \\
\hline Рентабельность, \% & 55,3 & 49,9 & 22,4 & 13,1 & 20,2 \\
\hline Доход на 1 га & 15736,8 & 16329,3 & 7803,4 & $-1821,0$ & 13743,9 \\
\hline
\end{tabular}

Так, за последние 5 лет показатель рентабельности производства кукурузы снизился на 42,2 \%. Такой спад произошел из-за роста производственных затрат, которые увеличились а 1770,6 руб. по сравнению с 2015 годом и составили в 2019 году 11514,0 руб. на 1 га (табл. 3).

Согласно таблицы 3 значительное снижение показателя рентабельности производства отмечено в 2018 году, что составило 13,1 \%. Это обусловлено как снижением урожайности и валового сбора культуры, так и средней цены реализации. Перечисленные факторы повлияли на увеличение себестоимости и снижение дохода с 1 гектара (-1821,0 руб.).

Анализ динамики себестоимости 1 тонны за последние пять лет показал тенденцию роста себе- стоимости единицы продукции. Расчет показателей динамики выявил, что в период с 2015 по 2019 годы себестоимость 1 тонны кукурузы увеличилась на 2947,2 руб. или на 52,8 \%. Однако в 2019 году произошло увеличение данного показателя до 20,2 \%, что связано с повышением цены на зерно вследствие снижения объемов производства зерна кукурузы в крае.

Анализ структуры затрат на 1 га посева и урожайности на себестоимость 1 тонны зерна кукурузы позволил определить резервы снижения себестоимости. Значительный удельный вес в составе затрат на производство составляют семена, агрохимикаты, горюче-смазочные материалы. Общехозяйственные затраты, как и общепроизвод- 
ственные, имеют высокий удельный вес в себестоимости продукции, поэтому дальнейшее развитие должно базироваться на поиске путей снижения себестоимости продукции, оптимизации структуры затрат на производство культуры. В сложившихся условиях, необходим анализ внутренних резервов сокращения расходов на производство культуры (табл. 4).

Таблица 4. Структура затрат на производство кукурузы в Краснодарском крае

\begin{tabular}{|l|c|c|c|c|c|c|}
\hline \multirow{2}{*}{ Наименование статей затрат } & \multicolumn{5}{|c|}{ Сумма затрат на 1 га, руб., по годам } & \multicolumn{2}{c|}{$\begin{array}{c}\text { Структура, } \\
\text { \% }\end{array}$} \\
\cline { 2 - 6 } & $\mathbf{2 0 1 5}$ & $\mathbf{2 0 1 6}$ & $\mathbf{2 0 1 7}$ & $\mathbf{2 0 1 8}$ & $\mathbf{2 0 1 9}$ & $\mathbf{4 0 , 6}$ \\
\hline $\begin{array}{l}\text { Материальные затраты } \\
\text { (семена, агрохимикаты, ГСМ) }\end{array}$ & 13773,9 & 15818,8 & 16266,9 & 15566,0 & 16005,0 & 9,6 \\
\hline $\begin{array}{l}\text { Заработная плата } \\
\text { с отчислениями }\end{array}$ & 3056,6 & 3421,8 & 3516,6 & 3659,0 & 3766,0 & 20,6 \\
\hline $\begin{array}{l}\text { Текущий ремонт } \\
\text { и амортизация }\end{array}$ & 4114,0 & 5098,9 & 5265,3 & 6769,0 & 8092,0 & 29,2 \\
\hline $\begin{array}{l}\text { Общехозяйственные затраты } \\
\text { и прочие расходы }\end{array}$ & 10130,0 & 10836,6 & 11900,6 & 9592,0 & 11514,0 & 29,0 \\
\hline Всего расходов на 1 га & 31074,5 & 35176,0 & 36949,4 & 35586,0 & 39377,0 & 100,0 \\
\hline
\end{tabular}

Необходимо обратить внимание на оптимизацию технологического процесса производства кукурузы, а также применение новых подходов в технологии выращивании, использование в посевах новых агрохимикатов, которые позволят снизить химическую нагрузку.

Важным резервом оптимизации затрат на производство кукурузы является использование в посевах новых высокоурожайных гибридов отечественной селекции, адаптированных для выращивания в почвенно-климатических условиях Кубани. В настоящее время кубанскими селекционерами создано большое разнообразие гибридов, предназначенных как для интенсивных технологий возделывания, так и для ресурсосберегающих. Ежегодно на Государствен- ное сортоиспытание передается 4-5 новых гибридов, которые превосходят по урожайности стандартный гибрид и отличаются высоким качеством [1].

\section{Выводы}

Анализ эффективности производства кукурузы в Краснодарском крае показывает, что потенциальные возможности позволяют увеличить объем производства, повысить рентабельность, создать условия для обеспечения населения безопасной отечественной сельскохозяйственной продукцией путем совершенствования технологии возделывания культуры, использования новых высокопродуктивных гибридов кубанской селекции, применения новых средств защиты растений и минеральных удобрений.

\section{ЛИТЕРАТУРА}

1. Государственный реестр селекционных достижений (Сорта растений). Сорта культуры «Кукуруза» - ФГБНУ «Госсорткомиссия», 2019. [Электронный ресурc]. - URL:http: //https://gossortrf.ru/(дата обращения: 05.02.21).

2. Краснодарский край в цифрах. 2015: Стат. сб. / Краснодарстат - Краснодар, 2016. - 307 с.

3. Краснодарский край в цифрах. 2016: Стат. сб. / Краснодарстат - Краснодар, 2017. - 327 с.

4. Краснодарский край в цифрах. 2017: Стат. сб. / Краснодарстат - Краснодар, 2018. - 306 с.

5. Краснодарский край в цифрах. 2018: Стат. сб. / Краснодарстат - Краснодар, 2019. - 302 с.

6. Коробка, А.Н. Система земледелия Краснодарского края на агроландшафтной основе [Текст] / А.Н. Коробка, С.Ю. Орленко, Е.В. Алексеенко, Н.Н. Малышева и др. - Краснодар, 2015. - 352 с.

7. Министерство сельского хозяйства Российской Федерации. - [Электронный ресурс]. - Официальный сайт Минсельхоз России. - URL: https://mcx.gov.ru/analytics / (дата обращения: 06.02.21).

8. Сельское хозяйство в России. 2019: Стат. сб. / Росстат - С 29 М., 2019. - 91 с.

9. Шиндин, А.П. Кукуруза. Современная технология выращивания. / А.П. Шиндин, В.Н. Бгринцева, Т.И. Борщ, А.Г. Горбачева, В.С. Сотченко, Е.Ф. Сотченко, Ю.В. Сотченко - Москва. - 2009. - 127 с.

10. Шпаар, Д. Кукуруза: выращивание, уборка, консервирование и использование: учеб. - практ. Рук. / Д. Шпаap, К. Гинапп и др. - Москва: DLV Агродело, 2006. - 390 с.

\section{REFERENCES}

1. State Register of Breeding Achievements (Plant Varieties). "Soya" varieties - FSBSI "Gossortkomissiya", 2019. [Electronic resource]. - URL: http: //https://gossortrf.ru/ (date of access: 05.02.21).

2. Krasnodar region in numbers. 2015: Stat. collection. / Krasnodarstat - Krasnodar, 2016. - 307 p.

3. Krasnodar region in numbers. 2016: Stat. collection. / Krasnodarstat - Krasnodar, 2017. - 327 p.

4. Krasnodar region in numbers. 2017: Stat. collection. / Krasnodarstat - Krasnodar, 2018. - 306 p.

5. Krasnodar region in numbers. 2018: Stat. collection. / Krasnodarstat - Krasnodar, 2019. - 302 p. 
6. Korobka, A.N. The farming system of Krasnodar region on an agrolandscape basis [Text] / A.N. Korobka, S.Yu. Orlenko, E.V. Alekseenko, N.N. Malysheva et al. - Krasnodar, 2015.- 352 p.

7. Ministry of Agriculture of the Russian Federation. - [Electronic resource]. - Official site of the Ministry of Agriculture of Russia. - URL: https://mcx.gov.ru/analytics / (date of access: 02/06/21).

8. Agriculture in Russia. 2019: Stat. collection / Rosstat - C 29 M., 2019.- 91 p.

9. Shindin, A.P. Corn. Modern growing technology. / A.P. Shindin, V.N. Bgrintseva, T.I. Borsch, A.G. Gorbachev, V.S. Sotchenko, E.F. Sotchenko, Yu.V. Sotchenko - Moscow. - 2009.- 127 p.

10. Shpaar, D. Corn: growing, harvesting, canning and use: Educational and practical guidelines/ D. Shpaar, K. Ginapp and others - Moscow: DLV Agrodelo, 2006.- 390 p.

\section{Гаркуша Сергей Валентинович \\ Директор \\ E-mail: arrri_kub@mail.ru}

\section{Тешева Сусанна Аслановна}

Ведущий научный сотрудник лаборатории семеноводства и семеноведения ФГБНУ «ФНЦ риса», доцент кафедры почвоведения Кубанского ГАУ

E-mail: satecheva@mail.ru

ФГБНУ «ФНЦ риса»

350091, Россия, г. Краснодар, пос. Белозерный, 3

E-mail: arrri_kub@mail.ru

ФГБОУ ВО «Кубанский государственный аграрный университет имени И. Т. Трубилина» 350044, Россия, г. Краснодар, ул. Калинина, 13

\author{
Garkusha Sergey Valentinovich \\ Direktor \\ E-mail: arrri_kub@mail.ru
}

\section{Tesheva Susanna Aslanovna}

Leading researcher of the laboratory of seed

production and seed science FSBSI Federal Scientific Rice Centre, associate professor of the department of soil science, Kuban State Agrarian University

E-mail: satecheva@mail.ru

FSBSI Federal Scientific Rice Centre

3, Belozerniy, Krasnodar, 350921, Russia

E-mail: arrri_kub@mail.ru

Federal State Budgetary Education Institution of Higher Education «Kuban State Agrarian University named after I.T. Trubilin 13 Kalinina st., Krasnodar, 350044, Russia 


\section{ПЕРВЫЙ КАМЕНЬ В ФУНДАМЕНТЕ КУБАНСКОЙ ШКОЛЫ ФИЗИОЛОГИИ РАСТЕНИЙ (К 140-ЛЕТИЮ СО ДНЯ РОЖДЕНИЯ \\ АКАДЕМИКА НИКОЛАЯ АЛЕКСАНДРОВИЧА МАКСИМОВА)}

Статья представляет собой отдельные страницы биографии выдающегося российского физиолога растений Н. А. Максимова - основоположника учения о формировании физиологических механизмов устойчивости растений к действию пониженных температур и засухе, связанные с работой в г. Екатеринодаре-Краснодаре в 1918-1921 гг. За это время при участии Н. А. Максимова были открыты Кубанский (Екатеринодарский) политехнический институт (КПИ), трансформированный в 1920 г. в Кубанский государственный университет (КубГУ), созданы агрономический факультет в КПИ, и естественный факультет в КубГУ. Н. А. Максимов, будучи проректором КПИ и КубГУ продолжал научно-исследовательскую деятельность по разработке лабораторных методов определения засухоустойчивости и морозостойкости зерновых культур. Во время работы в г. Екатеринодаре-Краснодаре академика Н. А. Максимова, были обозначены первые точки роста академического образования на Кубани и заложен первый камень в основание кубанской школы физиологии растений. Проведенное определение морозостойкости многих сортов растений способствовало более правильному их районированию, что явилось одним из практических способов борьбы с зимней гибелью растений. Были изучены и выяснены такие виды зимней гибели растений, как выпревание и гибель под ледяной коркой, причиной которых прежде ошибочно считали удушение растений. Хотя за истекшие годы было накоплено много новых фактов и создано теорий, но все же основной фактический материал, полученный А.Н. Максимовым и созданные теории на их основе не потеряли своего значения и в настоящее время.

Ключевые слова: Николай Александрович Максимов (1880-1952), академическое образование, физиология и экология растений, засухоустойчивость и морозостойкость растений, Екатеринодар, Краснодар.

\section{THE FIRST STONE OF THE KUBAN SCHOOL OF PLANT PHYSIOLOGY (TO THE 140TH ANNIVERSARY OF THE BIRTH OF ACADEMICIAN NIKOLAY ALEKSANDROVICH MAKSIMOV)}

The article represents separate pages of the biography of the outstanding Russian plant physiologist N.A. Maksimov, the founder of the doctrine of the formation of physiological mechanisms of plant resistance to the effects of low temperatures and drought, associated with work in the city of Yekaterinodar-Krasnodar in 1918-1921. During this time, with the participation of N.A. Maksimov, the Kuban (Yekaterinodar) Polytechnic Institute (KPI) was opened, which was transformed in 1920 into the Kuban State University (KubSU), the agronomic faculty at the KPI, and the natural faculty at the KubSU were created. NA Maksimov, being the vice-rector of KPI and KubSU, continued his research activities on the development of laboratory methods for determining the drought resistance and frost resistance of grain crops. While working in Yekaterinodar-Krasnodar, Academician N. A. Maksimov, the first points of growth of academic education in the Kuban were identified and the foundation stone of the Kuban school of plant physiology was laid. The determination of the frost resistance of many plant varieties contributed to their more correct zoning, which was one of the practical ways to combat winter death of plants. Such types of winter death of plants as damping-out and death under the ice crust were studied and clarified, the cause of which was previously mistakenly believed to be strangulation of plants. Although over the past years many new facts have been accumulated and theories have been created, nevertheless, the main factual material obtained by A.N. Maksimov and the theories created on their basis have not lost their significance at the present time.

Keywords: Nikolai Aleksandrovich Maksimov (1880-1952), physiology and biochemistry of plants, drought tolerance and frost resistance of plants, academic education, Ekaterinodar, Krasnodar. 


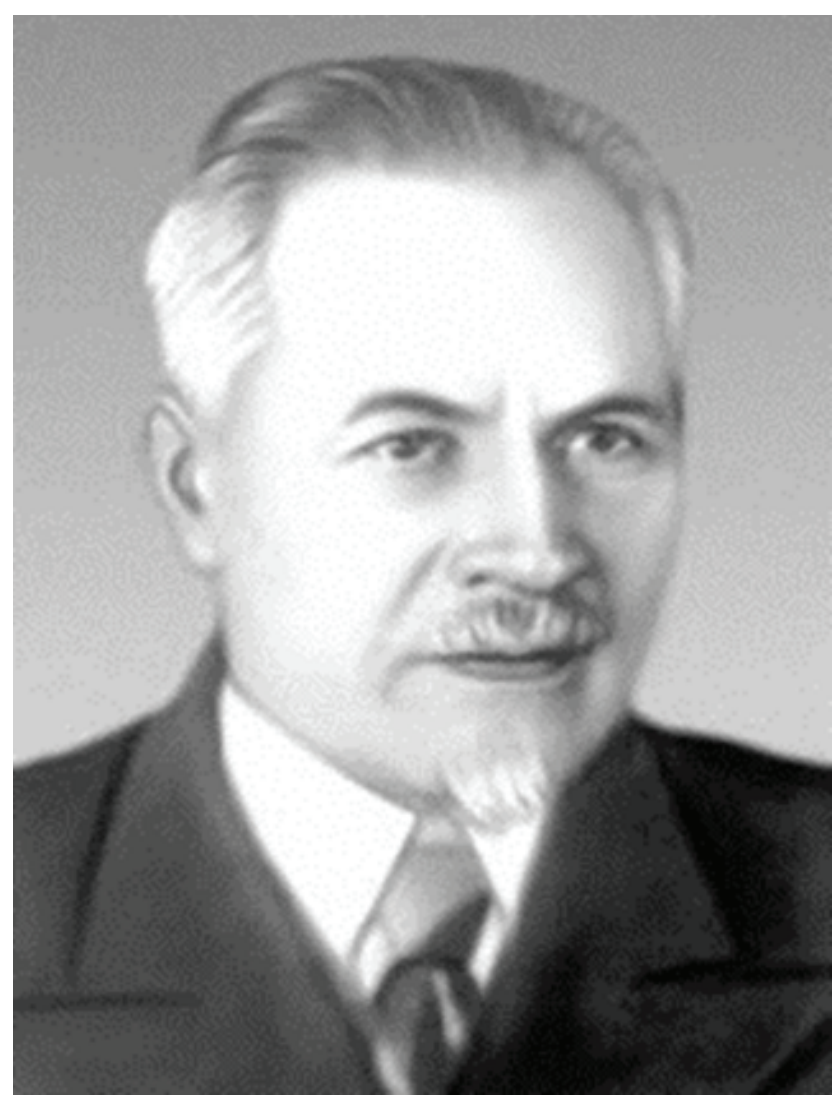

Максимов уже на 3 курсе университетского обучения проявлял безудержное и неутомимое рвение к познанию биохимических основ сложных физиологических процессов, происходящих в растительном организме. Вместе с тем, и в этом есть огромнейшая позитивная роль академического образования, это рвение могло принести качественные плоды только в условиях академической научной школы по биохимии и физиологии растений, в основу которой были положены принципы всесторонней аналитической работы по изучаемым феноменам, использование передовых разработок в области физико-химических методов анализа, экспедиционные геоботанические исследования естественных фитоценозов. В. И. Палладин и А. А. Рихтер увидели в Н. А. Максимове мощнейшую точку роста нарождающейся новой науки физиологии растений. Максимов сразу же после окончания университета влился в этот «золотой расплав», став в дальнейшем главной не только научной, но и научно-просветительской подвижнической силой славной школы петербургских физиологов растений.

Н. А. Максимов, будучи в 1903-1905 гг. на стажировке в германском университете в г. Гейдельберг, отмечает недостатки немецкого университетского, по сравнению с российским университетским образованием: «Обстановка в германских лабораториях больше напоминала контору, и в целом была полезна для нас, приучая к трудовой дисциплине в научной работе. Но, в конце концов, становилась скучной от чрезмерной размеренности в лабораторной жизни. В наших лабораториях чувствовалось больше увлечение работой, в германских больше выполнение обязанностей для получения диссертации для продвижения по научной карьере и т.п. В общем, надо сказать, что я всегда с большим удовольствием и огромной пользой работал у немцев, но оставаться там, на долго не хотелось. Там не чувствовалось того научного энтузиазма, который пронизывал у нас всю лабораторную жизнь и заставлял мириться с её неустройством и бедностью. И я всегда с радостью возвращался из заграничных дворцов в скромное здание ботанического кабинета Петербургского университета» [7]. В этих дневниковых записях раскрывается вся светлая сущность Н. А. Максимова, как человека подвижнических устремлений, для которого всегда приоритетом являлось истинное служение научному мировоззрению, зачастую в ущерб личным интересам, как человека беззаветно преданного Государству Российскому, отстаивавшему интересы могучего российского классического университетского образования, принципы которого были заложены ещё М. В. Ломоносовым.

Будучи заведующим, лаборатории физиологии в лесном институте, Максимов, в результате непрекращающейся экспериментальной работы, создаёт теоретическое обоснование устойчивости лесных пород к вымерзанию, разрабатывает лабораторные методы оценки морозостойкости, внедряет метод определения морозостойкости путём промораживания в специальных морозильных камерах. Совместно с молодым магистром Санкт-Петербургского политехнического института, будущим создателем теории полупроводниковых материалов, на которой основана вся современная электроника и цифровые технологии - A. И. Иоффе, создаётся мини-ионометр для изучения электрохимических явлений в замерзающих клетках растений. В эти годы Максимов делает важное научное открытие - о защитной роли моносахаров у растений при холодовом стрессе [3].

Максимов по своему духу не был кабинетным учёным. Сделав ряд важнейших открытий в области морозостойкости растений, он продолжает поиск биохимических основ роста различных физиологических групп растений. И как только ему в 1910 г. предоставляется возможность участия в экспедиции на о. Ява, с радостью принимает это приглашение. Экспедиция на о. Ява, в ботанический сад г. Бейтензорг в западной части острова, пробудила у Максимова интерес к проблемам экологической и сельскохозяйственной физиологии растений. С 1913 г. по 1918 г. Максимов работает на Кавказе. При его непосредственном участии на базе Тифлисского ботанического сада создаётся лаборатория физиологии и экологии растений. В это время Максимовым было опровергнуто го- 
сподствующее среди физиологов растений конца XIX - начало XX вв. мнение о более экономном расходе воды у ксерофитов. Он пришёл к выводу, что ксерофиты адаптированы к засухе, так как способны переносить обезвоживание клеток и тканей без относительного вреда для них [6].

Обострение политической обстановки в Закавказье в конце 1917 - начале 1918 года, заставляет Максимова искать новые центры притяжения. В августе 1918 года Н. А. Максимов переезжает работать в г. Екатеринодар. В 1918-1919 гг. Екатеринодар был центром притяжения научной и культурной интеллигенции Петрограда и других городов, охваченных бурями военно-революционного времени, которая, в силу нестабильной политической ситуации в стране, искала города, где возможно продолжение научной и культурной деятельности. Главный город Кубанской области - Екатеринодар, к 1917 году представлял собой крупный административно-промышленный центр Северного Кавказа со 120 тыс. населением, что являлось десятым показателем по числу жителей городов Российской империи [1], занимавший по темпам развития первое место среди городов Северного Кавказа. Так прирост населения с 1898 по 1914 гг. составил 35,8\% (что на 4,8\% выше, чем в крупнейшем городе Северного Кавказа - Ростове-на-Дону). В городе бурными темпами развивалась нефтеперерабатывающая, силикатная, сталелитейная, машиностроительная, кожевенная, маслобойная, мукомольная, пищевая отрасли промышленности. В окрестностях города открываются крупные опытные станции по селекции и семеноводству сельскохозяйственных культур, обеспечивающие посевным материалом всё возрастающие площади сельскохозяйственных посевов по всему Северному Кавказу. В 1916 году открывается Черноморско-Кубанская железная дорога - связавшая хлеборобные земли Кубано-Приазовской низменности с Екатеринодаром и Новороссийском. Город становится вторым, после Ростова-на-Дону крупным железнодорожным узлом Северного Кавказа. Такой бурный скачок развития промышленности и транспорта, уже сам по себе явился предпосылкой для открытия в г. Екатеринодаре высших учебных заведений, выпускающих инженеров высокой квалификации.

В сентябре 1918 года в здании І-ой Мужской гимназии на Соборной площади был открыт Кубанский (Екатеринодарский) Политехнический институт, поддерживаемый непосредственно Кубанским краевым правительством и лично А. И. Деникиным (рис. 1).

Н. А. Максимову стало известно о создании Кубанского политехнического института, где в то время работали знакомые ему петербургские учёные, такие как геолог С. А. Захаров - организатор экспедиций по исследованию горных пород и почв
Западного Кавказа, и гидрографии Азовского и Чёрного морей [3], почвовед А. А. Ярилов, метеоролог В. Н. Кедроливанский, гидробиолог В. А. Водяницкий, ботаник В. М. Арнольди, архитекторы А. А. Юнгер и А. П. Вайтенс. У Максимова был выбор переехать в Ростов-на-Дону в образованный на базе Императорского Варшавского университета в июле 1917 г. Донской государственный университет, где работал в то время один из его учителей Д. И. Ивановский, но он примкнул к екатеринодарской точке притяжения - Кубанскому политехническому институту.

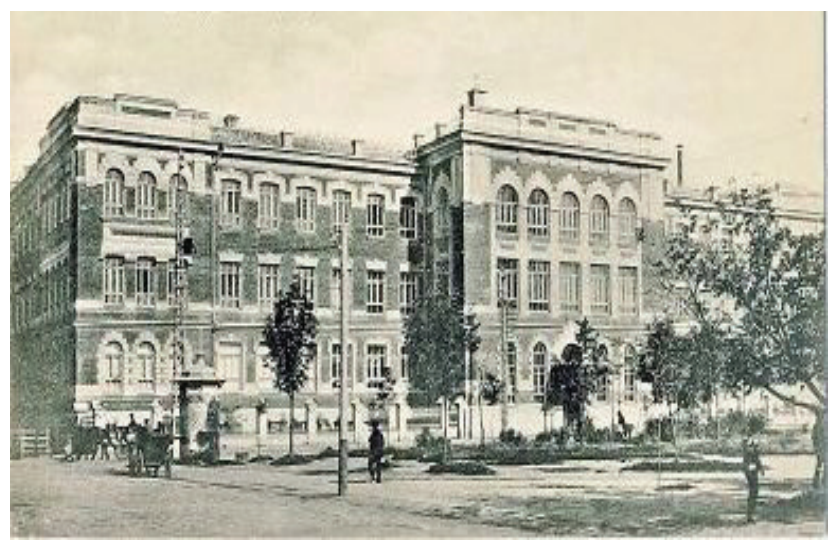

Н.А. Максимов, со свойственным ему энтузиазмом и неутомимым стремлением к созиданию, стал одной из основных движущих сил Кубанского политехнического института. Н. А. Максимов активно поддерживает идею создания в Екатеринодаре сельскохозяйственного музея. Он также понимает всю важность развития сельскохозяйственной физиологии растений на Кубани, поэтому в числе первых его решений стала организация агрономического факультета в Кубанском Политехническом институте - предтечи современного агрономического факультета КубГАУ. На базе созданного факультета Максимов продолжает свою научно-исследовательскую работу по морозо- и засухоустойчивости зерновых культур. Ещё в Лесном институте в 1907 - 1909 гг. он создаёт метод оценки морозостойкости древесных пород путём промораживания в специальных камерах почек [5]. Дальнейшая разработка этого метода продолжается в Екатеринодаре-Краснодаре 1919 1920 гг., но уже применительно к зерновым культурам. Указанные впервые Максимовым во время работы на Кубани методологические подходы по оценке устойчивости к холодовому стрессу сельскохозяйственных культур, легли в основу многих современных методов определения морозостойкости и холодостойкости создаваемых в настоящее время кубанскими селекционерами сортов озимого ячменя, озимой пшеницы, риса [2, 4, 8-10].

Однако, как пишет сам Максимов в трудных условиях, гражданской войны, многое из того, что задумывалось в Екатеринодаре, сделать не уда- 
лось [7]. В августе 1920 г. войска Деникина под натиском частей рабоче-крестьянской Красной армии под командованием Будённого, отступают из Екатеринодара. Екатеринодар переименовывают в Краснодар. Кубанский Политехнический институт подвергается реорганизации - на его базе создаётся Кубанский Государственный Университет, ректором которого становится палеогеограф и археолог Н. А. Маркс, известный своим солидарным отношением к социалистической форме государственного устройства. Н. А. Максимов принимает предложение Н. А. Маркса быть проректором Кубанского Государственного университета (КубГУ). Он продолжает активно работать в КубГУ, в котором решено было организовать три факультета: естественно-научный, медицинский и социолого-гуманитарный. В создании естественно-научного факультета Н. А. Максимов принимает непосредственное и самое активное участие. Несмотря на катастрофическое экономическое положение в 1921 году, как на Кубани, так и по всей стране, Максимов продолжает работать в Краснодаре до конца 1921 года, когда новые власти на Кубани принимают решение о закрытии КубГУ. Центр научной и культурной жизни Кавказа перемещается в Ростов-на-Дону в Донской государственный университет. Советская власть, так же как в своё время царское правительство, избирает центростремительный вектор развития высшего университетского образования путём создания небольшого количества базовых научных центров в крупнейших форпостах СССР. Мощнейший преподавательский состав КПИ (КубГУ) в конце 1921 года «разлетается» по земному шару... Максимов возвращается в родной Петроград (рис. 2).

Кубанским периодом завершается первая половина жизни выдающегося учёного. Перешагнув 40-летний рубеж, он уже успел сделать многое, для популяризации и организации высшего образования и академической науки в нашей стране. Открытые при его непосредственном участии лаборатории, факультеты и ВУЗы не должны забывать имя человека, стоявшего у истоков их зарождения - Николая Александровича Максимова.

\section{ЛИТЕРАТУРА}

1. Бондарь, В. В. Город Екатеринодар в пространстве и времени: Опыты исторической урбанистики. Монографический сборник. / В.В. Бондарь. - Краснодар: Изд-во Платонов, 2006. - 126 с.

2. Воробьев, Н.В. Продукционный процесс у сортов риса / Н.В. Воробьев, М.А. Скаженник, В.С. Ковалев. - Краснодар: Просвещение-Юг, 2011. - 199 с.

3. Еремеева, А. Н. «Находясь по условиям времени в провинции...»: практики выживания российских учёных в годы Гражданской войны/А.Н. Еремеева. - Краснодар: Изд-во Платонов, 2017. - 155 с.

4. Коломейченко, В.В. Продукционные процессы в посевах / В.В. Коломейченко. - Орёл: ОрёлГАУ, 2020. - 452 с.

5. Максимов, Н. А. О вымерзании и холодостойкости растений. Экспериментальные и критические исследования. / Н. А. Максимов // Известия СПб лесного института. - 1913. - Вып. 25. - С. 1-330.

6. Максимов, Н. А. К вопросу о суточном ходе и регуляции транспирации у растений. / Н.А. Максимов // Труды Тифлисского ботанического сада. - 1916. - Вып. 19. - С. 23-107.

7. Максимова, О. В. «Тюремная автобиография» Николая Александровича Максимова (комментарий к автобиографическим рукописям Н.А. Максимова) / О.В. Максимова // Историко-биографические исследования. - 2017. - T.9. - №1. - С. 69-89.

8. Скаженник, М. А. Методы физиологических исследований в рисоводстве / М.А. Скаженник, Н.В. Воробьёв, О.А. Досеева. - Краснодар, 2009. - 23 с.

9. Федулов, Ю. П. Методы определения устойчивости растений / Ю. П. Федулов. - Краснодар: Изд-во КубГАУ, 2015. - 39 c.

10. Шевцов, В. М. Способ определения морозостойкости озимого ячменя / В. М. Шевцов, Н. Г. Малюга, Т. Я. Бровкина и др. // Патент на изобретение RU 2471340C1. - Правообладатель КубГАУ. - от 15.06.2011.

\section{REFERENCES}

1. Bondar, V. V. The city of Yekaterinodar in space and time: Experiments in historical urban studies. Monographic collection. / V.V. Bondar, - Krasnodar: Platonov Publishing House, 2006. - 126 p.

2. Vorobiev, N.V. Production process of rice varieties / N.V. Vorobiev, M.A. Skazhennik, V.S. Kovalev. - Krasnodar: Education-South, 2011. - $199 \mathrm{p}$.

3. Eremeeva, A.N. "Being in the provinces according to the conditions of time ...": the practice of survival of Russian scientists during the Civil War. / AN. Eremeeva. - Krasnodar: Platonov Publishing House, 2017. - 155 p.

4. Kolomeichenko, V.V. Production processes in crops / V.V. Kolomeychenko. - Oryol: OrelGAU, 2020. - 452 p.

5. Maksimov, N.A. On freezing and cold resistance of plants. Experimental and critical research. / N.A.Maksimov // Izv. SPb Forestry Institute. - 1913. - V. 25. - P.1-330.

6. Maksimov, N.A. On the question of the diurnal course and regulation of transpiration in plants. / ON. Maximov // Proceedings of the Tiflis Botanical Garden. - 1916. - V. 19. - P. 23-107.

7. Maksimova, O.V. "Prison autobiography" by Nikolai Alexandrovich Maksimov (commentary on the autobiographical manuscripts of NA Maksimov) / O.V. Maximova // Historical and Biographical Research. - 2017. - V. 9. - № 1. - P. 69-89.

8. Skazhennik, M. A. Methods of physiological research in rice growing / M.A. Skazhennik, N.V. Vorobiev, O. A. Doseeva. - Krasnodar, 2009. - 23 p. 
9. Fedulov, Yu. P. Methods for determination of plant resistance / Yu. P. Fedulov. - Krasnodar: Publishing house of KubSAU, 2015. - $39 \mathrm{p}$.

10. Shevtsov, V. M. Method for determining the frost resistance of winter barley / V. M. Shevtsov, N. G. Malyuga, T. Ya. Brovkina [et al.] // Invention patent RU 2471340C1. - Copyright holder of KubSAU. - from 15.06.2011.

\section{Скаженник Михаил Александрович}

Заведующий лабораторией физиологии

E-mail: sma_49@mail.ru

\section{Иваненко Евгений Евгеньевич}

Соискатель лаборатории физиологии

E-mail: arri_kub@mail/ru

Bce: ФГБНУ «ФНЦ риса»

350921, Россия, г. Краснодар, пос. Белозерный, 3,
Skazhennik Mikhail Alexandrovich

Head laboratory of physiology

E-mail: sma_49@mail.ru

\section{Ivanenko Evgeniy Evgenievich}

Job seeker of the Laboratory of Physiology

E-mail: arri_kub@mail/ru

All: Federal Research Center of Rice

3, Belozerny, Krasnodar, 350921, Russia 


\section{ПРАВИАА ОФОРМАЕНИЯ АВТОРСКИХ ОРИГИНААОВ}

К публикации принимаются ранее не опубликованные статьи на русском и английском языках. Рукописи предоставляются на твердом и электронном носителях или по е-mail на адрес arrri_kub@mail.ru c пометкой «В редакцию журнала». Название файла должно содержать указание полугодия и года выпуска номера и фамилию автора латиницей, например, «1(2014)Ivanova.doc». Допустимые форматы файлов: .doc, .docx, .rtf. В отдельных случаях редакция может попросить представить отдельные файлы изображений или текст также в формате .pdf, либо в печатном варианте.

\section{Структура статьи}

- УДК:

- $\quad$ инициалы и фамилия, ученая степень автора/авторов и указание города и страны;

- название статьи, аннотация и ключевые слова на русском и английском языках;

- $\quad$ текст статьи;
- $\quad$ список литературы

- информация об авторе/авторах с указанием их фамилии, имени и отчества (полностью), должности и контактных данных (информация о месте работы, почтовый адрес, e-mail, контактный телефон) на русском и английском языках.

Статью рекомендуется чётко структурировать. Примерная структура: обзор, проблема, гипотезы, материал и методы, изложение, аргументация, обсуждение, выводы. Формально структуру статьи желательно отразить в заголовках внутри текста, выделенных полужирным шрифтом.

В случае необходимости перевод редактируется или осуществляется редакцией журнала.

\section{Форматирование текста}

Пожалуйста, избегайте собственного форматирования. Окончательное форматирование осуществляется редакцией.

- поля: верхнее, нижнее, правое - 1,5 см, левое - 2 см; шрифт - Times New Roman, 12 кегль; интервал полуторный; абзацный отступ - 1,25 см; без переносов;

- используйте курсив или полужирный курсив для примеров, а также наиболее важных терминов и понятий;

- избегайте использования подчёркиваний;
- таблицы и рисунки должны иметь отдельную нумерацию (например, Таблица 1, Рисунок 1) и быть озаглавлены, ссылки на них обязательны в тексте статьи. Название таблиц размещается над левым верхним углом таблицы, название рисунка - под рисунком по центру;

- в случае необходимости можно использовать обычные (не концевые!) пронумерованные сноски

\section{ОФормиение ссылок и списка митературы}

Библиографический список приводится в конце статьи в алфавитном порядке в виде пронумерованного списка источников под названием ЛИТЕРАТУРА. Библиографический список оформляется в соответствии с ГОСТ 7.1-2003 «Библиографическая запись. Библиографическое описание».

Книги Сметанин, А. П. Методики опытных работ по селекции, семеноводству, семеноведению и контролю за качеством семян риса / А. П. Сметанин, В. А. Дзюба, А. И. Апрод. - Краснодар, 1972. - 156 с.

Жученко, А. А. Адаптивная система селекции растений (эколого-генетические основы): в 2 т. / А. А. Жученко. - М.: Изд-во РУДН, 2001. - Т. 1. - 780 с; Т. 2. - 785 с.

Ерыгин, П. С. Физиология риса / П. С. Ерыгин. - М.: Колос, 1981. - 208 с.

Система рисоводства Краснодарского края / под. ред. Е. М. Харитонова. - Краснодар, 2011. - 316 с.

Авторефераты Ляховкин, А. Г. Мировой генофонд риса (Oryza sativa L.) в связи с проблемами селекции: автореф. дис. ... д-ра с.-х. наук / А. Г. Ляховкин. - Ленинград, 1989. - 58 с.

Диссертации Ковалев, В. С. Селекция сортов риса для Краснодарского края и Адыгеи и разработка принципов их рационального использования: дис. ... д-ра с.-х. наук в форме научного доклада : 06.01 .05 : защищена 25.03.1999 / В. С. Ковалев. - Краснодар, 1999. - 49 с.

Газеты, Рисоводство: научно-производственный журнал / учредитель: ГНУ «ВНИИ риса» Россельхозакадемии. - 2013, № 1 (22). журналы Краснодар: Просвещение-Юг, 2013. - ISSN 1684-2464.

Статьи Кумейко, Ю. В. Влияние ингибитора нитрификации на показатели, характеризующие режим азотного питания растений риса / Ю. В. Кумейко // Рисоводство. - Краснодар, 2013. - № 1 (22). - С. 66-70.

Чижикова, Н. П. Эволюция минералогического состава и микростроения основных типов почв Кубани при рисосеянии / Н. П. Чижикова, М. П. Верба // Почвы и их плодородие на рубеже столетий: Материалы 2-го съезда Белорусского общества почвоведов. - Минск, 2001. - Кн.1. - С. 232-233.

Электронные Зеленский, Г. Л. Российские сорта риса для детского и лечебного питания [Электронный ресурс] / Г. Л. Зеленский // Научресурсы ный журнал КубГАУ. - Краснодар, 2011. - № 72 (08). - Режим доступа: http://ej.kubagro.ru/2011/08/pdf/01.pdf (Дата обращения: 1.10.2014).

Зарубежные Satake, T. High Temperature-Induced Sterility in Indica Rice in the Flowering Stage / T. Satake, S. Yoshida // Japanese Journal of издания Crop Science. - 1978. - № 47. - P. 6-17.

Ссылки на зарубежные издания размещаются в алфавитном порядке, после отечественных. В тексте статьи ссылка на источник делается путем указания в квадратных скобках порядкового номера цитируемой литературы, например, [1]

Возвращение рукописи автору на доработку не означает, что статья принята к печати. После получения доработанного текста рукопись вновь рассматривается редколлегией. Доработанный текст необходимо вернуть вместе с ответом на все замечания рецензента. Датой поступления считается день получения редакцией финального варианта статьи.

Редколлегия сборника оставляет за собой право отклонять статьи, оформление и/или содержание которых не соответствует изложенным требованиям, а также статьи, получившие отрицательные оценки рецензентов.

Очередность публикации принятых материалов устанавливается в соответствии с внутренним планом редакции. 


\section{FORMATTING REQUIREMENTS}

Preparing the manuscript

Editorial address

Please send your manuscripts as an e-mail attachment to the following address: arrri_kub@mail.ru,

"Attn. Editors of the Magazine".

\section{Languages}

Manuscripts can be written in English or in Russian. In view of academic globalization, English articles are especially welcome.

\section{File format}

Please prepare the text of your manuscript and submit it as a .doc, .docx, .rtf file. Sometimes we may ask for a .pdf file for our reference, or for separate .jpg files.

\section{Manuscript materials should be ordered as follows:}

— authors' names, academic credentials, city and country;

- abstract of approximately 100 words and its Russian translation 5-7 key words;

- body of work;

— list of references and sources;

— information about the authors including full names, affiliation and contacts including mailing and e-mail addresses;

- If needed, translation can be effected by the editors.

\section{Basic formatting}

— Do not format the text, use standard paper size to A4

- Set line spacing to 1.5

— Use the same font (Times New Roman, point 12) throughout the document

- Use italics or boldface italics to draw the readers' attention to particular aspects of the text

— Tables and figures should be numbered separately (Table 1, Figure 1, etc.)

- Use footnotes

Final formatting will be done by the editors.

\section{Bibliographical references}

At the end of the manuscript, provide a full bibliography with the heading: REFERENCES.

Arrange the entries alphabetically by surnames of authors.

Some examples of references are given below.

Books and Modeling the Impact of Climate Change on Rice Production in Asia / edited by R. B. Matthews, M. J. Kroppf, monographs D. Bachelet, H. H. van Laar. - Wallingford: CAB INTERNATIONAL. - 289 p.

Yoshida, S. Fundamentals of Rice Crop Science / S. Yoshida. - Los Banos, 1981. - 269 pp.

Journal Satake, T. High Temperature-Induced Sterility in Indica Rice in the Flowering Stage / T. Satake, S. Yoshida // articles Japanese Journal of Crop Science. - 1978. - № 47. - P. 6-17

Online Vaghefi, N. The Economic Impacts of Climate Change on the Rice Production in Malaysia [Electronic source] sources / N. Vaghefi, M. Nasir Shamsudin, A. Makmom, M. Bagheri // International Journal of Agricultural Research. - 2011. - Vol. 6, Issue 1. - Pp. 67-74. - Access mode: http://scialert.net/abstract/?doi=ijar.2011.67.74 (Accessed 1.10.2014).

References in the text and in the footnotes should include the number of the publication as in the references list enclosed in square brackets, Eg.: [1]. 
Подписано в печать Тираж изготовлен в типографии

22.04.2021 ИП Копыльцов П.И.,

Формат 60*84/8 394052, г. Воронеж,

Бумага офсетная ул. Маршала Неделина, д. 27, кв. 56.

Усл. печатн. листов 12,5 Заказ № 1584. Тираж 500 экз. 